UNIVERSIDADE DE SÃO PAULO

FACULDADE DE FILOSOFIA, LETRAS E CIÊNCIAS HUMANAS PROGRAMA DE PÓS-GRADUAÇÃO EM HISTÓRIA SOCIAL

\title{
A ESCRAVIDÃO EM SÃO MATEUS/ES: ECONOMIA E DEMOGRAFIA (1848-1888)
}

Maria do Carmo de Oliveira Russo

Orientador: Prof. Dr. Horacio Gutiérrez

São Paulo

2011 


\title{
A ESCRAVIDÃO EM SÃO MATEUS/ES: ECONOMIA E DEMOGRAFIA (1848 -1888)
}

\author{
Tese apresentada ao Programa de Pós-Graduação \\ em História Social do Departamento de História \\ da Faculdade de Filosofia, Letras e Ciências \\ Humanas da Universidade de São Paulo para a \\ obtenção do título de Doutor em História Social. \\ Orientador: Prof. Dr. Horacio Gutiérrez.

\section{VERSÃO CORRIGIDA} \\ Exemplar original disponível no CAPH / FFLCH
}

São Paulo

2011 


\section{FOLHA DE APROVAÇÃO}

Maria do Carmo de Oliveira Russo

A escravidão em São Mateus/ES:

Economia e Demografia (1848-1888)

Tese apresentada ao Programa de Pós-Graduação em História Social do Departamento de História da Faculdade de Filosofia, Letras e Ciências Humanas da Universidade de São Paulo para a obtenção do título de Doutor em História Social.

Aprovado em:

\section{Banca Examinadora}

Prof. Dr.

Instituição: Assinatura:

Prof. Dr.

Instituição: Assinatura:

Prof. Dr.

Instituição:

Assinatura:

Prof. Dr.

Instituição:

Assinatura:

Prof. Dr.

Instituição:

Assinatura: 


\section{AGRADECIMENTOS}

O ato de agradecer sempre foi na maioria das vezes, a meu ver, uma situação simbólica, uma formalidade, uma cordialidade, um recurso, que a humanidade sempre se dispôs para expressar um reconhecimento. Embora às vezes superficial esse reconhecimento sempre se constituiu consciente, ou inconscientemente, em uma estratégia de sobrevivência. Porém, esta experiência de pesquisa para o doutorado me provou exatamente o contrário: agradecer não é nada formal e cordial. Nunca foi tão importante e necessário para mim agradecer sinceramente a alguém, sobretudo ao meu orientador, Prof. Horacio Gutiérrez - ou mais do que isso, um amigo que fui conquistando no desenrolar dos trabalhos, com sua paciência 'de Jó', ao suportar inúmeras idas e vindas na minha pesquisa, principalmente a sã ignorância em informática, no que diz respeito ao manejo do programa SPSS utilizado para a ordenação dos dados da pesquisa. A atuação do Prof. Horacio para a realização dessa pesquisa foi fundamental, pois só uma grande consciência como a sua, poderia compreender, com sabedoria e perspicácia, este momento complexo da minha vida, conseguindo, com sua firmeza, manter-me firme, embora fragilizada, até o final dos trabalhos. Nossas inúmeras e demoradas reuniões de orientação me fez crescer imensamente e me acrescentou um cabedal significativo de conhecimentos.

Agradeço também às pessoas com as quais fui me deparando ao longo dessa trajetória de estudos, os professores 'da casa' Marina Mello e Souza e Carlos de Almeida Bacellar, que gentilmente aceitaram participar da banca de Qualificação, os quais forneceram importantes contribuições para a melhoria deste trabalho.

Fico grata também aos professores Eduardo França Paiva (UFMG), expressão da última geração de pesquisas sobre a escravidão em Minas Gerais, e Adriana Pereira Campos (UFES), ilustre representante capixaba na historiografia sobre a escravidão e orientadora de pesquisas de história do Espírito Santo.

Agradeço ainda aos amigos professores e pesquisadores capixabas Anna Lúcia Côgo (UESC/Ilhéus) e Aldieris B. A. Caprini (IFES-ES), interlocutores incansáveis dos assuntos relativos à história do Espírito Santo, com suas pesquisas voltadas para esse Estado. 
Também não posso deixar de referenciar agradecimentos aos transcritores dos documentos cartoriais que muito me ajudaram na coleta, Herinaldo (do ICHS/UFOP/Mariana) no início da pesquisa e Leandro Dias (do CEDOC/UESC/Ilhéus) nos momentos finais.

No mais, dedico este trabalho ao meu pai Paulo (in memoriam) e ao meu irmão de mesmo nome, único de sangue (também in memoriam), que ainda tão jovem partiu há alguns meses, levando consigo boa parte de mim, deixando-me meio desprovida de luz e brilho essenciais para a conclusão de qualquer trabalho, quanto não um trabalho de cunho intelectual. 


\section{RESUMO}

O presente estudo tem por finalidade abordar aspectos demográficos e econômicos da escravidão em São Mateus, região do norte do Espírito Santo, na segunda metade do século XIX. O porto da vila de São Mateus (cidade a partir de 1848), considerado um vetor de desenvolvimento, escoava a produção agrícola regional, principalmente a farinha de mandioca e, posteriormente, o café, abrigando também um ativo mercado de escravos. Colocamos em destaque certas características das estruturas agrárias e sócioeconômicas da região de São Mateus, procurando demonstrar a importância da instituição escravista em tal contexto, assim como as especificidades da escravidão nesta área. Para tanto, consultamos e analisamos documentos cartoriais da cidade livros do Notariado ou Livro de Notas - do Cartório de $1^{\circ}$. Ofício, onde se encontram registros de alforrias, de compra e venda, hipotecas, doações, aluguel de escravos, dentre outros, relativos ao período de 1863 a 1888. Utilizamos também os registros oficiais referentes à escravidão produzidos no âmbito do governo provincial, sobretudo os Relatórios dos Presidentes da Província a partir da década de 1840 e a legislação contida no Ementário das Leis Provinciais (1835-1888) e nas Posturas Municipais, no período estudado. Neste contexto procurou-se destacar as peculiaridades regionais inerentes à região em foco, sua formação histórica, sua oligarquia agrária, assim como sua relação com o porto marítimo de Conceição da Barra, outrora, Barra de São Mateus, para num segundo momento, analisar especificamente a escravidão nesta região no período estudado, destacando as contribuições que a pesquisa nesta documentação traz para o conjunto da historiografia capixaba.

Palavras-chave: Escravidão; São Mateus/ES - Brasil; Século XIX. 


\section{ABSTRACT}

In this essay it is intended to address some aspects of the slavery in São Mateus - a port town located in the north of the state of Espírito Santo, Brazil - in the nineteenth century's second half. The São Mateus village harbor - a vector for the development of that region at the time - used to gather and distribute all the agricultural production of the region - mainly the manioc flour, which was considered to be one of the best products on the coast - and later, the coffee, sheltering a large slave market. Special attention is given to certain features of São Mateus' agricultural, social and economical structures, aiming to demonstrate the importance of the slavery institution in context as well as the specificity of slaveholding in the region. Therefore, analyses and consultations of Notation Books have been carried out in the Registry Office, where a range of documentes have been found, such as slaves liberation registers, documents of purchase and sale, mortgages, donations, slaves rental, among others, through 1863 to 1888. We also use official records relating to slavery produced under the provincial government, particularly the reports of the Presidents of the Province from the 1840s and the legislation contained in Ementário of Provincial Laws (1835-1888) and Municipal Posturesin the period studied. In this context was to highlight the regional peculiarities inherent in the region in focus, its historical formation, their agrarian oligarchy, as well as its relationship with the seaport of Conceição da Barra, then called Barra de São Mateus, for a second time, analyze, specifically slavery in this region in the period studied, highlighting possible contributions that search this documentation can bring the whole historiography of the state of Espírito Santo.

Key-words: Slavery; São Mateus/ES, Brazil; 19th century. 


\section{SUMÁRIO}

INTRODUÇÃO 11

CAPÍTULO 1 - O ESPÍRITO SANTO NO OITOCENTOS: ESPECIFICIDADES HISTÓRICAS DE SÃO MATEUS.

1.1. Aspectos históricos e geográficos de São Mateus 18

$1.2 \mathrm{O}$ século XIX e a formação da oligarquia agrária ............................................ 24

1.3. O perfil sócio-econômico: os escravos, o porto, a farinha e o café ....................... 36

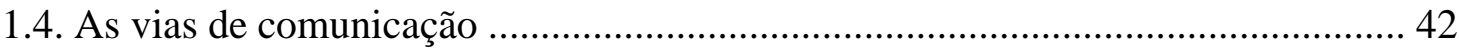

1.5. A escravidão em São Mateus via oralidade ....................................................... 49

\section{CAPÍTULO 2 - A ESCRAVIDÃO NAS DISCUSSÕES OFICIAIS E NA} LEGISLAÇÃO PROVINCIAL.

2.1. A escravidão nos Relatórios dos Presidentes da Província ................................... 63

2.2. A Legislação Provincial e as Posturas Municipais ............................................ 88

\section{CAPÍTULO 3 - O ESCRAVO ENQUANTO MERCADORIA}

3.1. Padrões de compra e venda de escravos em São Mateus na segunda metade do século XIX 100

3.1.1. Perfil dos compradores e dos vendedores 108

3.1.2. Perfil dos escravos: sexo, idade, preços e outras variáveis 114

3.1.3. Firmas comercializadoras de escravos 129

3.2. Atividades mercantis com escravos 134

3.2.1. Hipotecas, penhoras, aluguel, empréstimos, doações e permutas 138

\section{CAPÍTULO 4 - PADRÕES DAS ALFORRIAS EM SÃO MATEUS}

4.1. Conteúdo, processo de elaboração e registro das cartas de alforrias 151

4.2. As diversas modalidades das alforrias 154

4.3. As alforrias de São Mateus 159

4.4. As variáveis nas cartas de liberdade 176

CONSIDERAÇÕES FINAIS 184

FONTES E BIBLIOGRAFIA 


\section{LISTA DE TABELAS}

\section{CAPÍTULO 1:}

Tabela 1: População de São Mateus em 1764 20

Tabela 2: População da Vila de São Mateus e da Província do Espírito Santo na primeira metade do século XIX.

Tabela 3: População do Espírito Santo e São Mateus - Anos: 1856 e 1872 ....................................... 29

Tabela 4: Distribuição da população escrava na Província do Espírito Santo por regiões (1824-1876) 41

\section{CAPÍTULO 2:}

Tabela 1: População da Província do Espírito Santo em 1856

Tabela 2: Declínio da população escrava no Espírito Santo (1872 a 1887).

\section{CAPÍTULO 3:}

Tabela 1: Dados gerais da compra e venda de escravos em doze Livros de Notas de São Mateus...... 106

Tabela 2: Percentual do número de escravos comprados pelos 10 maiores compradores..................... 109

Tabela 3: Percentual do número de escravos vendidos pelos 10 maiores vendedores........................ 110

Tabela 4: Patente dos compradores de escravos em São Mateus (1863-1887)................................ 111

Tabela 5: Patente dos vendedores de escravos em São Mateus (1863-1887)..................................... 112

Tabela 6: Percentual do número de compradores de escravos em São Mateus (1863-1887)............. 113

Tabela 7: Percentual do número de vendedores de escravos em São Mateus (1863-1887)................. 114

Tabela 8: Sexo dos escravos comprados/vendidos em São Mateus (1863-1887) ............................. 114

Tabela 9: Idade e sexo dos escravos comprados/vendidos em São Mateus (1863-1887)................... 115

Tabela 10: Número de escravos comprados/vendidos por décadas em São Mateus .......................... 118

Tabela 11: Média de preços de escravos comprados/vendidos por décadas em São Mateus.............. 119

Tabela 12: Média de preços de escravos comprados/vendidos por ano em São Mateus (1863-1887) 120

Tabela 13: Cores dos escravos comprados/vendidos em São Mateus (1863-1887)........................... 123

Tabela 14: Ocupações dos escravos comprados/vendidos em São Mateus (1863-1887)..................... 124

Tabela 15: Estado conjugal dos escravos comprados/vendidos em São Mateus (1863-1887)............ 125

Tabela 16: Origem dos escravos comprados/vendidos em São Mateus (1863-1887).......................... 127

Tabela 17: Sexo do comprador/firmas compradoras de escravos em São Mateus .............................. 130

Tabela 18: Sexo do vendedor/firmas vendedoras de escravos em São Mateus (1863-1887)............... 131

Tabela 19: Número de escravos comprados por sexo do comprador/ firmas compradoras............... 131

Tabela 20: Número de escravos vendidos por sexo do vendedor/ firmas vendedoras......................... 132

Tabela 21: Ano do registro da compra e sexo do comprador/firmas compradoras de escravos............133

Tabela 22: Ano do registro da venda e sexo do vendedor/firmas vendedoras de escravos.................. 134

Tabela 23: Documentos avulsos/ negócios escravos em São Mateus (1863-1888).............................. 136

\section{CAPÍTULO 4:}

Tabela 1: Cartas de alforria / Percentual por sexo dos escravos em São Mateus (1863-1888)............ 159

Tabela 2: Registro das alforrias por décadas em São Mateus (1863-1888) ........................................ 159

Tabela 3: Tipos de cartas de alforria / Percentual das formas de concessão (1863-1888)................... 160

Tabela 4: Tipos de cartas de alforria por sexo dos cativos em São Mateus (1863-1888)................... 161

Tabela 5: Formas de concessão/ valor da alforria/ sexo dos escravos (1863-1888)............................ 160

Tabela 6: Valor das alforrias e ano da declaração (1863-1888) ...................................................... 165

Tabela 7: Metade alforriada/coartações por sexo dos cativos (1863-1888).................................... 168

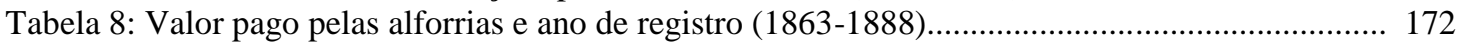

Tabela 9: Cartas de Liberdade por via Judicial/protesto (1866-1885) .............................................. 174

Tabela 10: Sexo e idade dos escravos nas cartas de alforria em São Mateus (1863-1887)......... 176

Tabela 11: Percentual da idade dos escravos nas cartas da alforria em São Mateus (1863-1887).. 177

Tabela 12: Idade e preço dos cativos nas cartas de alforria em São Mateus (1867-1888)................ 179

Tabela 13: Preços médios de cativos nas cartas de alforria em São Mateus (1867-1888).................. 180

Tabela 14: Forma de concessão e idade do escravo nas cartas de alforria (1863-1888).................. 181 
Tabela 15: Cores dos escravos nas cartas de alforria em São Mateus (1863-1888)

Tabela 16: Etnia dos escravos nas cartas de alforria em São Mateus (1863-1888)..................... 184

Tabela 17: Formas de ocupação do escravo nas cartas de alforria (1863-1888) ....................... 185

Tabela 18: Estado conjugal do escravo nas cartas de alforria (1863-1888)

\title{
QUADROS
}

Quadro 1: Maiores credores de negociações de escravos em São Mateus (1863-1887)..... 214

Quadro 2: Outros tipos de negócios comerciais envolvendo escravos em São Mateus (1863-1888)... 218

\section{GRÁFICOS}

Gráfico 1: Sexo dos escravos comprados/vendidos em São Mateus (1863-1887).

Gráfico 2: Número de escravos comprados/vendidos por décadas em São Mateus ......................... 118

Gráfico 3: Média de preços de escravos comprados/vendidos por décadas em São Mateus............... 119

Gráfico 4: Cores dos escravos comprados/vendidos em São Mateus (1863-1887)............................. 123

Gráfico 5: Ocupações dos escravos comprados/vendidos em São Mateus (1863-1887).................... 124

Gráfico 6: Estado conjugal dos escravos comprados/vendidos em São Mateus (1863-1887).............. 126

Gráfico 7: Origem dos escravos comprados/vendidos em São Mateus (1863-1887)....................... 128

\begin{abstract}
ANEXOS
Anexo 1:

Tabela 1: Nomes de escravos nas cartas de alforria de São Mateus (1863-1888)

Anexo 2:

Tabela 1: Idade e sexo dos escravos comprados/vendidos em São Mateus (1863-1887).................... 208

Tabela 2: Preços dos escravos comprados/vendidos em São Mateus (1863-1887)............................. 209

Tabela 3: Preços dos escravos comprados/vendidos por sexo em São Mateus (1863-1887).............. 210

Tabela 4: Preços dos escravos por décadas e por sexo em São Mateus (1863-1887)........................... 211

Anexo 3:

Quadro1: Credores e devedores nas hipotecas e penhoras de escravos em São Mateus (1866-1885). 214

Quadro 2: Outros tipos de negócios comerciais envolvendo escravos em São Mateus (1863-1888) .. 218
\end{abstract}

Anexo 4:

Transcrições de documentos

Anexo 5:

Mapas de São Mateus 250

Mapa 1: Mapa do norte do Espírito Santo e da região de São Mateus no século XIX

Mapa 2: : Mapa do Espírito Santo de 1878 
INTRODUÇÃO 
A historiografia capixaba dedicada ao estudo de História do Espírito Santo geralmente esteve mais voltada para o século XVI, explorando os fatos que marcaram os primeiros tempos da Capitania ou para a segunda metade do século XIX, quando se deu a implantação da cultura cafeeira no território espírito-santense, paralelamente à formação de núcleos coloniais de imigração estrangeira.

A maior parte dos trabalhos historiográficos produzidos neste sentido até então, relatam os primeiros episódios da colonização, com foco na ação dos jesuítas - com destaque para o Padre Anchieta -, e também na decadência do primeiro donatário da Capitania, Vasco Fernandes Coutinho, suas relações com o governo-geral e com a coroa portuguesa. Neste contexto, a sacralização da concepção de 'capitanias fracassadas', amplamente difundidas na historiografia brasileira, torna-se um estigma para a Capitania do Espírito Santo, e, “a partir de então, cai sobre ela o silêncio" e o "Espírito Santo só reaparece na historiografia referente ao século XIX com o café e a imigração estrangeira" (SALETTO, 1984), gerando uma lacuna temporal de mais de dois séculos e meio da história capixaba no conjunto das pesquisas historiográficas sobre o tema.

Esse 'reaparecimento' do Espírito Santo na historiografia, contudo, foi muito limitado, devido à falta de estudos regionais, já que os historiadores se concentraram mais nos temas ligados às particularidades da economia cafeeira e nos processos da colonização estrangeira, sendo poucas as pesquisas que romperam este padrão. Apenas alguns estudos avançaram em outras direções, a exemplo de Vilma Almada, com o tema da escravidão na segunda metade do século XIX (ALMADA, 1984), Nara Saletto com o estudo da transição para o trabalho livre e a pequena propriedade no Espírito Santo (SALETTO, 1996), e o trabalho mais recente da historiadora Anna Lúcia Côgo acerca das estruturas agrárias do norte do Espírito Santo no século XIX (CÔGO, 2007).

Outra questão que percorre a historiografia capixaba referente ao final do século XIX, é a tendência à produção de trabalhos mais voltados para a região centro-sul da província, devido ao maior desenvolvimento da cultura cafeeira e à maior concentração da imigração estrangeira nestas áreas, no contexto da expansão das fronteiras agrícolas cafeeiras do Vale do Paraíba fluminense e também pela proximidade da Corte, o maior centro econômico do Império e para onde se direcionava o maior volume das exportações da província capixaba.

Sendo assim, nossa pesquisa se voltou para uma região ainda pouco investigada do Espírito Santo, ou seja, o extremo norte da província, especificamente a Freguesia de 
São Mateus e entornos, demonstrando sua relevância social e econômica, assim como suas potencialidades e singularidades enquanto parte integrante do conjunto da história capixaba, considerando que esta região, mesmo sendo uma das áreas de povoamento mais antigo do Espírito Santo, permaneceu de certa forma 'isolada' no contexto regional e 'esquecida' no conjunto da produção historiográfica.

O processo histórico verificado em São Mateus é predominantemente caracterizado por sua agricultura baseada na produção da farinha de mandioca, assim como pelas condições naturais favoráveis da região, a exemplo da navegabilidade do seu rio e a localização privilegiada e estratégica do seu porto fluvial muito próximo à costa brasileira, possibilitando o estabelecimento e consolidação das relações comerciais de São Mateus ao longo do período estudado, com diversos núcleos populacionais do centro-sul da província, do Rio de Janeiro (Corte) e também da Bahia, os quais se tornaram os centros consumidores de boa parte de sua produção agrícola.

As boas condições de navegabilidade do rio São Mateus, o transformou na via natural de escoamento da produção agrícola da cidade de São Mateus até o porto marítimo da Vila da Barra de São Mateus (atual município de Conceição da Barra) estreitando e fortalecendo as relações sócio-mercantis entre essas duas localidades, as quais permaneceram por longos períodos entrelaçadas economicamente e formando uma espécie de "complexo regional agrícola e portuário" de natureza semelhante, onde predominava a produção e a exportação da farinha de mandioca" (CÔGO, 2007).

Visando obter uma idéia mais ampla desta região, destacaremos suas especificidades históricas no conjunto da província capixaba, fazendo referências ao período de 59 anos em que São Mateus esteve sob o domínio político-administrativo da comarca de Porto Seguro (de 1764 a 1823), e dos processos verificados posteriormente, tentando caracterizar e esboçar o perfil sócio-econômico regional, o qual, grosso modo, pode ser sintetizado na movimentação comercial dos portos de São Mateus e da Vila da Barra, na produção e exportação da farinha de mandioca por um longo período, no comércio regional de escravos e na gradual implantação da lavoura cafeeira naquela área a partir de meados do século XIX.

Nessa perspectiva, abordaremos, no primeiro capítulo, alguns aspectos da formação política, social e econômica da região em foco, os quais, somados às suas características geográficas, possibilitaram a sua afirmação enquanto 'cidade portuária' 
do extremo norte do Espírito Santo, canalizando e escoando a maior parte da produção agrícola regional durante toda a segunda metade do século XIX.

Tendo por referência a elevação da vila de São Mateus à categoria de cidade em 1848, procurando destacar determinados aspectos da sua formação política e também da conjuntura sócio-econômica anteriores a esse período, sobretudo aqueles mais significativos na conformação dos processos históricos verificados na segunda metade do século XIX, até a abolição da escravatura, quando constatamos a formação de uma oligarquia agrária e mercantil, proprietária de terras e de escravos, que dominava também os setores mais importantes do comércio regional. Esta oligarquia assegurou as suas bases de dominação regional, através de uma política de casamentos entre uma mesma parentela e na qual identificamos a existência de um verdadeiro clã parental, com forte influência política. Esta oligarquia mateense foi polarizada pela família do coronel e do major Antonio Rodrigues da Cunha, pai e filho, respectivamente, sendo este último também conhecido como o Barão de Aimorés, o qual se tornou o personagem (integrante) mais referenciado desta oligarquia no cenário histórico de São Mateus ao longo da segunda metade do Oitocentos.

Durante praticamente todo o período imperial, São Mateus se apresentou como maior produtor de farinha de mandioca da Província do Espírito Santo e um dos mais importantes da costa brasileira, além de se inserir com relativo sucesso na incipiente produção cafeeira da província capixaba. O rio São Mateus, atuando como uma via natural de escoamento da produção agrícola regional deve ser considerado vetor de peso no desenvolvimento desta região, pois viabilizou uma movimentação dos fluxos mercantis no porto fluvial de São Mateus, próximo à costa brasileira, onde se sobressai também um ativo mercado de escravos.

No segundo capítulo, nos ocupamos da discussão de alguns assuntos referentes à escravidão mencionados nos Relatórios dos Presidentes da Província do Espírito Santo, nos registros da legislação provincial (compilada no Ementário das Leis Provinciais 1835/1888) e na legislação municipal, intitulada Posturas Municipais.

Neste vasto repertório documental, selecionamos os temas relacionados à escravidão na província, e especificamente na região de São Mateus, enfatizando as questões e situações recorrentes tratadas nos documentos, onde se destaca a formação de guerrilhas para a captura de escravos fugitivos, a repressão aos quilombolas e 
quilombos, já que a presença dos quilombos e a ação/reação dos negros cativos foi uma constante em toda a história de São Mateus.

Ressaltamos ainda que o leque dos documentos citados são importantes para os estudos dedicados à história do Espírito Santo no período imperial, pois trazem ricas informações acerca da situação geral da província e fornecem importantes dados sobre diversos temas e questões relativas ao contexto sócio-econômico e político capixaba da segunda metade do Oitocentos, entre estes, temas ligados à escravidão no Espírito Santo e em São Mateus.

No terceiro capítulo, voltamos nossa atenção para o sistema escravista regional, visto que a formação e efetivação da sua oligarquia agrária e mercantil (representada por Aimorés) acarretou a aquisição e posse não somente de extensas propriedades e fazendas, mas também de plantéis significativos de escravos e um aumento nas movimentações econômicas regionais referentes às negociações mercantis envolvendo os escravos, tais como compra e venda, hipotecas, permutas, doações entre outros, incluindo nesse grupo as concessões de alforrias. O escravo, neste contexto, situa-se não só como elemento produtor (mão-de-obra), mas também como produto mercadológico.

Abordaremos as vicissitudes dos processos referentes à compra e venda de escravos, em São Mateus, através de uma exploração geral das características destas transações, com base na análise dos documentos cartoriais que registraram esses tipos de negócios com escravos na região entre os anos de 1863 e 1888, os quais se encontram sob a guarda do Cartório de $1^{\circ}$. Ofício de São Mateus. Nestas fontes cartoriais foram observadas as variáveis intrínsecas ao próprio escravo enquanto mercadoria, tais como sexo, cor, idade, qualificação profissional, preço, entre outros, além de considerarmos também as variáveis externas que influenciavam o mercado de escravos, tais como os fatores políticos, sociais ou econômicos que marcaram o período em foco. Neste sentido, relacionamos os maiores proprietários de escravos, os maiores vendedores e compradores, delineando com mais precisão o grupo oligárquico que foi se configurando no desenvolvimento de nossas pesquisas.

Procuramos, portanto, observar os padrões de compra e venda dos escravos, o perfil dos compradores e dos vendedores, assim como a variação de preços, numa tentativa de obter uma caracterização geral deste mercado em São Mateus na segunda metade do século XIX. Neste contexto, considerar-se-á o escravo numa condição sócioeconômica dupla, ou seja, enquanto mão-de-obra e mercadoria, reconhecendo no 
escravo uma importante força de trabalho e uma mercadoria altamente rentável, utilizando para isso embora de forma superficial, o conceito de 'capital escravistamercantil' desenvolvido sobretudo em estudos de Iraci del Nero da Costa dentre outros.

O grupo dos documentos cartoriais 'avulsos' que registraram outras atividades mercantis com escravos, em São Mateus serão também analisados, dentre estes, as hipotecas, doações, permutas, penhoras, aluguéis de escravos, transferências e locações de serviços de serviços, pagamentos e confissões de dívidas envolvendo escravos, entre outros. Esses documentos registraram, de alguma forma, a movimentação econômica da cidade de São Mateus no período estudado, afirmando a utilização do escravo como um bem econômico e que poderia ser capitalizado. Também as atividades mercantis praticadas pelos escravos, (sobretudo os 'escravos de ganho' e escravos 'a jornal'), serão analisadas, numa tentativa de ampliar o enfoque dos usos do escravo enquanto meio de obtenção de riquezas.

Por fim, no capítulo quatro serão analisados os padrões de alforrias no município mateense, a partir da caracterização das fontes cartorárias relativas ao tema, ou seja, as cartas de liberdade, assim como as variáveis contidas nestas fontes, que perfazem um total de 172 cartas, registradas entre os anos de 1863 a 1888. Consideramos que essa massa documental é de extrema importância, para desvendar os meandros da instituição escravista na região, visto que tanto os proprietários de escravos utilizaram-se das alforrias como forma de controle da escravaria quanto, por outro lado, também os escravos, foram sujeitos que empregaram as mais diversas estratégias para conquistar a liberdade e autonomia em tal contexto histórico.

Finalmente, ressaltamos que dentre a bibliografia consultada para a elaboração deste estudo, sobretudo os estudos diretamente relacionados às temáticas da escravidão no Brasil, selecionamos títulos que nos deram contribuições específicas para embasar nossas análises, os quais serão diretamente referenciados e citados no corpo do texto que se segue.

Esperamos que as contribuições reunidas nessa tese possa vir a esclarecer a compreensão da escravidão do norte do Espírito Santo bem como de sua história econômica e demográfica. 
CAPÍTULO 1

O ESPÍRITO SANTO NO OITOCENTOS: ESPECIFICIDADES HISTÓRICAS DE SÃO MATEUS 
1.1. Aspectos históricos e geográficos de São Mateus.

O Estado do Espírito Santo é demarcado geograficamente, já desde os tempos coloniais, em três principais áreas banhadas por rios que deságuam no seu litoral, os quais centralizaram a expansão econômica destas regiões: o sul, por cujo território passam os rios Itabapoana e Itapemirim, o centro, onde se localiza a foz dos rios Santa Maria e Jucu, que deságuam na Baía de Vitória e o norte cortado pelos rios Doce e São Mateus, ambos "nascidos” em Minas Gerais.

A região de São Mateus, localizada acima do Rio Doce, compreendia até o final do século XIX, uma extensa área limitada ao sul pelo rio Barra Seca e ao norte pelo rio Mucuri. Abrangendo praticamente todo o extremo norte da Província do Espírito Santo, ultrapassava a atual divisa com a Bahia estendendo-se até a região do rio Mucuri (fronteira natural com a então Capitania de Porto Seguro).

A cidade de São Mateus, localizada à margem direita do rio, de mesmo nome (que também conhecido é por rio Cricaré), ${ }^{1}$ possui um porto, o qual encontra-se a uma distância de aproximadamente oito 'léguas' (quarenta e oito quilômetros) do Oceano Atlântico. O rio São Mateus constitui a base hidrográfica regional. (v. mapas em ANEXO 5)

O porto fluvial de São Mateus, localizado na vila de São Mateus (elevada a cidade em 1848), era uma espécie de 'anexo portuário' ao porto marítimo da Barra de São Mateus (atual município de Conceição da Barra), sua foz no Oceano Atlântico. Embora em linha reta a distância entre esses dois portos não ultrapasse alguns poucos quilômetros (menos de dezoito), as 'oito léguas' (ou quarenta e oito quilômetros) do porto de São Mateus até a Barra, se deve à grande sinuosidade do rio neste trecho, pois ao aproximar-se da costa, ele se direciona em linha reta para o norte, seguindo paralelo e bem próximo ao Oceano Atlântico até a sua foz na Barra de São Mateus. O porto da Barra servia de ancoradouro para embarcações de grande porte, que transitavam a costa brasileira.

O rio São Mateus, ou rio Cricaré ${ }^{2}$, serve em seu percurso de desaguadouro para pequenos afluentes e outros maiores, os chamados 'braços' sul e norte ${ }^{3}$. O rio Cricaré

\footnotetext{
${ }^{1}$ Este rio nasce no nordeste mineiro e percorre banhando todo o extremo norte do Espírito Santo.

${ }^{2}$ Nome de origem indígena, que em tupi significa kiri-kerê - aquele que é propenso a dormir, ou seja, 'dorminhoco'.
} 
possuía um porto principal na povoação que foi se formando sob o nome de São Mateus. O porto foi o responsável pelo futuro desenvolvimento econômico, social e político regional, com seu comércio ativo no largo a beira do rio, já que se tratava de um porto fluvial, atrelado a outro marítimo, servindo de entreposto comercial não só para as fazendas, mas também para as embarcações que transitavam a costa brasileira, principalmente entre as províncias da Bahia e do Rio de Janeiro.

Possuidora de um potencial de populações indígenas, entre eles os temidos Botocudos, a região foi palco de vários conflitos entre colonizadores e índios durante o período colonial - tal como a citada Batalha do Cricaré ${ }^{4}$.

Com a descoberta do ouro em Minas Gerais, a entrada do rio São Mateus para o interior foi proibida no início do século XVIII, para que se evitasse o contrabando do ouro e o trânsito de colonos para o sertão, ocasionando assim um maior isolamento da região. A proibição pela coroa portuguesa permaneceu até o final do Setecentos e a hostilidade entre índios e brancos perdurou ao longo do século XIX.

A coroa portuguesa proibiu que os capixabas e outros exploradores subissem o rio São Mateus (que possui uma extensão de aproximadamente quarenta léguas: mais exatamente $188 \mathrm{~km}$ em seu braço sul e $244 \mathrm{~km}$ em seu braço norte) até a sua nascente na Serra da Safira em Minas Gerais, proibindo-se simultaneamente aos mineiros descerem até o mar pelas vias fluviais. Assim como a rota do rio Doce, a do São Mateus foi também rigorosamente controlada pela coroa portuguesa e a circulação de pessoas proibida, considerando que ambos nascem em Minas e atravessam todo o território centro-norte e norte capixaba até desaguar no mar, o rio Doce na vila de Regência, região de Linhares.

\footnotetext{
${ }^{3} \mathrm{O}$ 'braço sul' do rio São Mateus ou rio Cricaré, nasce na região de São Félix de Minas, se encontrando com o 'braço norte' ou Rio Cotaxé, em território capixaba, onde, após se encontrarem, percorrem uma distância de $65 \mathrm{~km}$ até a foz, formando a bacia hidrográfica do São Mateus. O 'braço norte' nasce também em território mineiro, bem próximo ao braço sul, na região conhecida como Alto São Mateus. Outros rios como o São Domingos, o Santana, o Mariricu, o rio Preto dentre outros, fazem parte do conjunto hidrográfico do São Mateus.

${ }^{4}$ A Batalha do Cricaré, ocorrida em 1558 na confluência dos rios Cricaré e Mariricu foi um confronto entre os índios botocudos e os colonizadores portugueses, por determinação de Mem de Sá, Governador Geral do Brasil na época. Mem de Sá enviou o próprio filho, Fernão de Sá, no comando de cinco barcos com aproximadamente 200 homens, em auxílio a Vasco Fernandez Coutinho, donatário da Capitania do Espírito Santo, no sentido de conter os levantes indígenas contra a dominação portuguesa no território capixaba. Este episódio culminou com a morte de centenas de índios e também do filho de Mém de Sá e de outros portugueses. Depois da morte do filho, o próprio Mem de Sá organizou um massacre aos índios que, segundo alguns historiadores, se constitui na primeira grande exterminação dos nativos. O episódio é historicamente conhecido como a primeira vitória de Mem de Sá no Brasil.
} 
O historiador Xavier da Veiga, em suas Efemérides Mineiras, relaciona seis decretos régios entre 1725 e 1785 proibindo abertura de caminhos para Minas Gerais 5 .

Tais resoluções culminaram com a ordem expedida pelo Real Erário do Governo de Minas, em 1773, proibindo que qualquer pessoa, sob qualquer pretexto, utilizasse as vias fluviais mineiras que desaguassem no mar, seja pela sua foz ou pela sua cabeceira.

Os 'sertões do leste', onde a maior parte da região de São Mateus estava localizada, passaram a ser mencionados nos documentos oficiais e mapas da época como 'áreas proibidas'.

A estratégia da coroa portuguesa de isolar toda a região oeste do Espírito Santo, transformando-a num espaço impenetrável, limitou definitivamente o território desta província, durante o século XIX, confinando-a à faixa litorânea. Sendo assim, a única via de acesso à região de São Mateus e à região do rio Doce, era pela costa, seja pela direção sul que levava a Vitória, a capital da província, ou pela direção norte, que levava a Porto Seguro, a sede da capitania mais próxima. Neste contexto, a 'área proibida' tornou-se refúgio seguro para as tribos bravias ainda restantes no leste brasileiro (particularmente os Botocudos), concentrando assim um grande contingente indígena durante todo o século XIX.

Remontando à segunda metade do século XVIII, mais especificamente em 1764, quando São Mateus é elevado à categoria de vila, a povoação contava, oficialmente, com um agrupamento de quatrocentos e cinqüenta e três habitantes. (v. Tabela 1)

Tabela 1: População de São Mateus em 1764

\begin{tabular}{|c|c|c|}
\hline Habitantes da vila / condição familiar & $\mathrm{N}^{\mathrm{o}}$. de indivíduos & $\%$ \\
\hline Casais (em no ${ }^{\circ}$ de $98 \times 2=196$ hab.) & 196 & 43,3 \\
\hline Filhos destes casais & 206 & 45,5 \\
\hline Viúvos & 12 & 2,6 \\
\hline Filhos destes viúvos & 17 & 3,8 \\
\hline Viúvas & 7 & 1,5 \\
\hline Filhos destas viúvas & 15 & 3,3 \\
\hline Total de habitantes & 453 & 100,0 \\
\hline
\end{tabular}

\footnotetext{
5 XAVIER DA VEIGA, José Pedro. Efemérides Mineiras (1664-1897). Belo Horizonte: Fund. João Pinheiro/CEHC, 1998.
} 
Neste conjunto demográfico estão excluídos todos os índios, que eram a maioria da população: tanto os que trabalhavam para os colonos, assimilados culturalmente ou não (possivelmente havendo ainda muitos 'escravizados'), quanto os que habitavam a região, sem contato direto com o branco. Os negros eram em número pouco expressivo, e também não se encontram incluídos neste contingente.

Originalmente pertencente à Capitania do Espírito Santo, que nessa época estava sendo administrada diretamente pela coroa portuguesa através do governo-geral do Brasil, em 1764 São Mateus é elevada à categoria de vila e encampada à jurisdição da Capitania de Porto Seguro.

O Ouvidor de Porto Seguro, depois de vários levantamentos, entendeu que a povoação reunia as condições necessárias para ser elevada à categoria de Vila e também que sua implantação era necessária como ponto de apoio militar para evitar a entrada de intrusos na região onde haviam descoberto o ouro ${ }^{6}$.

O Ouvidor de Porto Seguro nesta época era Thomé Couceiro de Abreu, autoridade designada pelo Ministro de Ultramar Marquês de Pombal. Orientado pelo Marquês, Couceiro realizou estudos e pesquisas sobre as potencialidades do rio São Mateus, constatando riquezas minerais e agrárias na região. No contexto da anexação de São Mateus à jurisdição de Porto Seguro, sob a administração de Couceiro, conseqüência das inovações pombalinas, foi proporcionada à região uma organização administrativa e um relativo desenvolvimento econômico baseado na exportação da farinha de mandioca. Neste período, São Mateus e Porto Seguro estabeleceram uma sólida relação comercial, com a compra e venda de escravos e com o comércio da farinha de mandioca.

Somente em 1823, cinqüenta e nove anos depois, a região voltará a fazer parte dos domínios da antiga Capitania do Espírito Santo, naquele momento já Província do Espírito Santo. Este fato de a vila de São Mateus permanecer atrelada à Capitania de Porto Seguro por mais de meio século, teve o efeito de distanciar um pouco a região do contexto da província capixaba, conferindo-lhe uma peculiaridade regional, pois a vila absorve acentuadamente a influência cultural baiana.

O período em que São Mateus esteve sob o domínio de Porto Seguro foi de

\footnotetext{
${ }^{6}$ NARDOTO, Eliezer e LIMA, Herinéia. História de São Mateus. São Mateus: EDAL,1999, p. 35.
} 
crescimento econômico, graças à expansão da cultura da farinha de mandioca que era exportada principalmente para Porto Seguro, para Ilhéus e para o Recôncavo, sendo também um período de organização administrativa, quando foram nomeados os respectivos administradores da vila.

\begin{abstract}
Quando Couceiro elevou a povoação a Vila, o Alcaide (administrador) era Francisco Gomes Sardinha [...] O interesse do Ouvidor Geral [Couceiro] e a avidez do Marquês de Pombal pelas riquezas da região foram responsáveis por aquela ingerência. São Mateus desenvolvia-se, então, como o primeiro pólo de riqueza do Espírito Santo, capaz de levar vida autônoma em relação ao resto da Província, numa época em que nem Vitória, como sede da Capitania, tinha recursos próprios para viver ${ }^{7}$.
\end{abstract}

Quando comparado ao processo verificado na vila de São Mateus, o desenvolvimento da povoação da Barra de São Mateus foi mais lento e tardio, mesmo considerando que a sua localização litorânea dava-lhe maior possibilidade de desenvolvimento devido a sua estratégica posição geográfica e das instalações do seu porto (embora precário até a década de 1870, quando se inicia a construção do cais). Somente em 1831 formou-se a Paróquia de Nossa Senhora da Conceição (hoje a padroeira do município), e dois anos depois, em 1833, a povoação foi elevada à categoria de vila, recebendo a denominação de Villa da Barra de São Matheus. Sua emancipação político-administrativa em relação a São Mateus, que se tornara vila desde 1764, ocorrerá somente em1891, embora já possuísse câmara municipal desde fins do século XVIII.

Por volta de 1835/36, a Tesouraria da Fazenda ou Tesouraria Provincial instalou um órgão arrecadador das Rendas Provinciais na Barra de São Mateus devido a sua localização na costa Atlântica, servindo de ponto de apoio para as embarcações que transitavam a costa brasileira. Estrategicamente, a administração provincial optou por instalar a Recebedoria de Rendas Provinciais (também chamada de Mesa Recebedora) na área do porto da Barra de São Mateus e não na cidade de São Mateus, onde foi instalada uma Agência de Rendas (ou Agência Arrecadadora). A diferença entre ambas, é que as primeiras tinham uma estrutura mais complexa e eram instaladas em locais estratégicos do ponto de vista arrecadador, ou seja, nas regiões onde havia maior volume de produção e transações comerciais, principalmente nos pontos de trânsito marítimo, enquanto as 'agências', mesmo tendo as mesmas funções das 'recebedorias',

\footnotetext{
${ }^{7}$ NARDOTO, Eliezer e LIMA, Herinéia. História de São Mateus. São Mateus: EDAL, 1999, p.41.
} 
ou seja, a arrecadação dos tributos e taxas que incidiam sobre a região, apresentavam uma estrutura menos complexa do que as referidas recebedorias.

Da Barra de São Mateus partiam embarcações a vela ou a vapor que faziam a ligação comercial com a vila de São Mateus, embarcações estas que pudessem franquear a barra, ou seja, que pudessem ultrapassá-la, visto que esta variava de acordo com as marés. O desenvolvimento da região de São Mateus, facilitado pelo rio, navegável em parte de seu percurso, é acentuado a partir de então.

Podemos inferir que este 'conjunto' portuário, constituído por dois portos anexos um ao outro, juntamente com a vocação agrícola da região voltada para a produção da farinha de mandioca, foi o vetor do desenvolvimento regional ao longo do Oitocentos.

No transcurso do século XVIII para o XIX, a região começa a se destacar como uma grande produtora de farinha de mandioca, sendo que alguns autores regionais chegam a afirmar, de forma exagerada e sem apresentar dados e comprovações, que já a partir das primeiras décadas do XIX, a região era a maior produtora de farinha de mandioca da costa brasileira.

Conforme ressaltamos, durante o tempo em que São Mateus esteve sob a jurisdição de Porto Seguro (1764 - 1823) ocorreu um crescimento das atividades produtivas e comerciais. Neste período, a região ganhou certo impulso com a implantação de fazendas e sítios de cana-de-açúcar e mandioca, registrando também, a existência de um relativo contingente de escravos. Foram dados alguns incentivos para que colonos se estabelecessem nas terras localizadas entre a vila e o mar, havendo ainda a imigração de famílias baianas para a região.

O processo de entrada de escravos através do porto, iniciado desde o período colonial, se estendeu e se intensificou durante o século XIX ${ }^{8}$, principalmente após a proibição do tráfico transatlântico em 1850 até a abolição da escravatura, com maior ou menor intensidade conforme a década, visto que se tratava de um centro comercial regional, de entrada e escoamento de mercadorias produzidas nas fazendas, principalmente a farinha de mandioca, seus derivados, e posteriormente, o café.

\footnotetext{
${ }^{8}$ Segundo o recenseamento realizado pelo Presidente da Província, Inácio Accioli de Vasconcellos em 1827 e registrado em sua Memória Statística da Província do Espírito Santo escrita no anno de 1828, a população parda cativa de São Mateus era de 666 indivíduos e a negra cativa de 2361 indivíduos, ou seja, um total de 3027 escravos, para uma população de 6255 pessoas.
} 
1.2. O século XIX e a formação da oligarquia agrária.

Já observamos que durante todo o período imperial São Mateus é considerado o maior produtor de farinha de mandioca da Província do Espírito Santo e também um dos mais importantes da costa brasileira, além de se inserir, com relativo sucesso, na incipiente produção cafeeira da província capixaba e que, o rio São Mateus, atuando como via natural de escoamento agrícola, funcionou como um vetor de desenvolvimento regional. O porto exercia a função de entreposto natural da produção regional destinada a Vitória, ao comércio com a Bahia e à capital da Colônia (instalada no Rio de Janeiro desde 1763).

Em contraposição ao quadro de estagnação econômica apresentado pela Província do Espírito Santo nas primeiras décadas do século XIX, segundo a maioria dos autores capixabas, na região de São Mateus registra-se um período de crescimento econômico.

Neste contexto, o retorno desta região à jurisdição capixaba significará uma espécie de 'salvação da pátria', pois esta nova situação fornecerá muitos recursos à província que, naquele momento, se encontrava em situação precária. Assim, incorporado novamente à Província do Espírito Santo, em 1823, São Mateus passa a suprir parte das rendas perdidas pela província com o desmembramento das Vilas de Campos dos Goitacazes e São João da Barra, que passam a ser vinculadas à província do Rio de Janeiro. Eram essas duas vilas que forneciam a maior receita para a província do Espírito Santo, até iniciarem um processo de desmembramento a partir de 1821, vinculando-se inteiramente à Província do Rio de Janeiro em 1832. Os municípios de São João da Barra e Campos dos Goitacazes (antiga Capitania da Paraíba do Sul) estiveram ligados administrativamente à Província do Espírito Santo desde 1753, por provisão do Conselho Ultramarino, até 1832, quando são desanexados, passando à jurisdição para o Rio de Janeiro.

Com o advento da Independência do Brasil, São Mateus tornou-se o centro das atenções da Província do Espírito Santo, pois:

Esta vila aderiu ao governo da Junta Provisória em 22 de janeiro de 1823[instalada em Vitória]. Sendo chamada pelo conselho da Vila de Cachoeira [Bahia], para mandar ali seus deputados, a Câmara hesitou por se achar sujeita ao Espírito Santo pela ata celebrada no mesmo dia 22 de janeiro. O governo supremo determinou, por Aviso de dez de abril de 
1823, que continuasse a pertencer ao governo da Província do Espírito Santo, enquanto outra coisa não fosse determinada pelo corpo legislativo ${ }^{9}$.

Ao aderir a este movimento, São Mateus desafia a resistência baiana, pois a essa altura Porto Seguro já vivia sob o domínio do Recôncavo, contrário à Independência, "onde o general Madeira plantara o bastião da resistência portuguesa". ${ }^{10}$

É importante lembrar que a Independência na Bahia foi declarada somente em dois de julho de 1823. O fato de São Mateus manter compromisso comercial com a Bahia, colocou os mateenses em situação delicada porque, sendo favoráveis à Independência, estavam se colocando contra o general Madeira de Melo, chefe das tropas portuguesas na região e contrário à Independência. Devido a isso, registra-se que somente a Câmara de São Mateus não compareceu à sessão realizada em Vitória para o juramento da Independência e Aclamação de D.Pedro I, em 12 de outubro de 1822.

Nesta conjuntura, a Junta Provisória instalada na capital da Província do Espírito Santo tomou providências ao pedir ao Governo Central fornecimento de tropas para a defesa de São Mateus enquanto território sujeito ao governo capixaba.

Assim,

\begin{abstract}
em janeiro de 1823, mais de quatro meses depois de proclamada a Independência, o Comandante das Armas da Província do Espírito Santo, Fernando Teles da Silva, desembarcou em São Mateus, trazendo uma guarnição de mais de quinhentos soldados, para dar garantias aos cidadãos mateenses adeptos da Independência do Brasil ${ }^{11}$.
\end{abstract}

A importância da região no contexto da província capixaba neste período tornase evidente quando, no ano de 1835, "além da Comarca pré-existente que passou a denominar-se Vitória, foram criadas também as de Itapemirim e São Mateus". ${ }^{12}$

\footnotetext{
${ }^{9}$ MARCELINO, José apud OLIVEIRA, José Teixeira de. História do Estado do Espírito Santo. Vitória: Fundação Cultural do Espírito, 2a . ed., 1975, p. 281.

${ }^{10}$ OLIVEIRA, José Teixeira de. História do Estado do Espírito Santo. Vitória: Fundação Cultural, $2^{\mathrm{a}}$. ed., 1975 , p. 280.

11 NARDOTO, Eliezer e LIMA, Herinéia. História de São Mateus. São Mateus: EDAL Ed.,1999. p. 47.

12 CUNHA, Eduardo Durão. “São Mateus e sua História”. Revista São Mateus 450 anos. São Mateus: EDAL: 1994.
} 
Tabela 2: População da vila de São Mateus e da Província do Espírito Santo na primeira metade do século XIX.

\begin{tabular}{|c|c|c|c|c|c|c|c|}
\hline Categorias/ & $\mathrm{N}^{\mathrm{o}}$. & $\%$ & $\mathrm{~N}^{\mathrm{o}}$. & $\%$ & $\mathrm{~N}^{\mathrm{o}}$ & $\%$ & $\%$ \\
\hline Habitantes & Homens & Homens & Mulheres & Mulheres & Total & Categ. & $\mathrm{H}+\mathrm{M}$ \\
\hline
\end{tabular}

A - População de São Mateus. Ano: 1827

$\begin{array}{lrrrrrrr}\text { Brancos } & 472 & 49,8 & 475 & 50,2 & 947 & 15,1 & 100,0 \\ \text { Índios } & 393 & 50,2 & 390 & 49,8 & 783 & 12,5 & 100,0 \\ \text { Pardos Livres } & 500 & 51,4 & 473 & 48,6 & 973 & 15,5 & 100,0 \\ \text { Pardos Cativos } & 333 & 50,0 & 333 & 50,0 & 666 & 10,6 & 100,0 \\ \text { Pretos Livres } & 298 & 56,8 & 227 & 43,2 & 525 & 8,4 & 100,0 \\ \text { Pretos Cativos } & 1.228 & 52,1 & 1.133 & 47,9 & 2.361 & 37,7 & 100,0 \\ \text { TOTAL } & \mathbf{3 . 2 2 4} & \mathbf{5 1 , 5} & \mathbf{3 . 0 3 1} & \mathbf{4 8 , 5} & \mathbf{6 . 2 5 5} & \mathbf{1 0 0 , 0} & \mathbf{1 0 0 , 0}\end{array}$

B - População do Espírito Santo. Ano: 1827

$\begin{array}{lrrrrrrr}\text { Brancos } & 4.011 & 48,1 & 4.325 & 51,9 & 8.336 & 23,2 & 100,0 \\ \text { Índios } & 2.647 & 47,5 & 2.714 & 52,5 & 5.361 & 15,0 & 100,0 \\ \text { Pardos Livres } & 3.507 & 96,9 & 4.110 & 3,1 & 7.617 & 21,2 & 100,0 \\ \text { Pardos Cativos } & 1.318 & 48,2 & 1.417 & 51,8 & 2.735 & 7,6 & 100,0 \\ \text { Pretos Livres } & 753 & 46,6 & 864 & 53,4 & 1.617 & 4,5 & 100,0 \\ \text { Pretos Cativos } & 5.432 & 53,2 & 4.781 & 46,8 & 10.213 & 28,5 & 100,0 \\ \text { TOTAL } & \mathbf{1 7 . 6 6 8} & \mathbf{4 9 , 2} & \mathbf{1 8 . 2 1 1} & \mathbf{5 0 , 8} & \mathbf{3 5 . 8 7 9} & \mathbf{1 0 0 , 0} & \mathbf{1 0 0 , 0}\end{array}$

Fonte: Vasconcellos, Inácio Accioli de. Memória Statistica da Província do Espírito Santo escrita no anno de 1828. APEES.

Os dados da Tabela 2-A, quando comparados aos dados da Tabela 1, mostra evidentemente que no período transcorrido entre 1764 e 1827 houve um aumento considerável do número de habitantes em São Mateus, assim como também uma maior diversificação na composição da sua população, já que no ano de 1827 o Censo populacional fornece detalhes acerca desta, pois inclui o número de escravos, embora o número de índios apresentado seja irrisório.

Segundo Durão Cunha, "após a independência e reincorporação ao Espírito Santo, tornou-se São Mateus, um oásis de prosperidade no tumulto em que vivia a província," ${ }^{13}$ em meio a epidemias de cólera e varíola e numa conjuntura em que faltavam verbas para tudo. Nesta situação, segundo o historiador, a cidade de São Mateus, "talvez pelo quase isolamento em que vivia, foi pouco atingida pelas epidemias e a agricultura continuava respondendo como o principal esteio da economia". ${ }^{14}$

\footnotetext{
${ }^{13}$ Ibidem, p. 32.

${ }^{14}$ Ibidem, p. 32.
} 
Conforme relato datado de 1847 do presidente da Província do Espírito Santo, Couto Ferraz, "a Vila de São Mateus tem assaz prosperado. Possui grandes fazendas, bons estabelecimentos, alguns engenhos e casas mui bem construídas, sendo a farinha o principal gênero de exportação" ${ }^{15}$. No mesmo relatório destaca também o crescimento da Vila da Barra de São Mateus, em que a agricultura vinha se desenvolvendo graças à boa qualidade da terra, principalmente em Itaúnas, "onde há uma povoação nascente com sessenta casas na divisa desta província com a Bahia”. ${ }^{16}$

Nesta conjuntura econômica, a vila de São Mateus foi elevada à categoria de município em 1848, passando a desfrutar de um considerável prestígio político na Província do Espírito Santo.

As terras do novo município estavam compreendidas entre o rio Barra Seca e o rio Mucuri. Seu porto - que atuava como entreposto comercial de escravos e de diversas outras atividades comerciais principalmente da farinha de mandioca, tornou-se parada obrigatória para muitos vapores de companhias brasileiras de navegação. O grande número de negros, escravos e livres, mantinha elevada a produção de farinha. Mesmo com a introdução do café e sua expansão a partir de meados do século XIX, o comércio da farinha foi a sua principal fonte de renda no decorrer do período estudado.

Neste contexto ocorre, a formação de uma sólida oligarquia rural, atuante na política local, representada pelo fazendeiro e comendador Antonio Rodrigues da Cunha, coronel da Guarda Nacional e comandante da Legião Norte da província. De seu casamento com Dona Rita Maria da Conceição Cunha, nasceram doze filhos, entre os quais destaca-se Antonio Rodrigues da Cunha, o Barão de Aimorés, considerado uma das personalidades mais marcantes da história de São Mateus no período imperial. ${ }^{17}$

Por volta de 1863, Antonio Rodrigues da Cunha, o (futuro) Barão de Aimorés, até então major da Guarda Nacional, também conhecido por major Cunha, iniciou a colonização do interior de São Mateus, implantando uma fazenda na Cachoeira do Cravo, primeira cachoeira rio acima, às margens do Cricaré (braço sul), localizada a

\footnotetext{
${ }^{15}$ Fragmento do Relatório do Presidente da Província do Espírito Santo Luis Pedreira de Couto Ferraz, em 11.10.1847. Biblioteca Digital do Arquivo Público do Estado do Espírito Santo (APEES).

${ }^{16}$ Ibidem, p. 57.

17 Entre seus filhos também se destacam: Reginaldo Gomes da Cunha, também comendador e comerciante na Corte, coronel Matheus Gomes da Cunha, fundador da fazenda e (posteriormente), município de Boa Esperança, Constança Gomes da Cunha, casada com o médico Graciano Santos Neves e mãe do governador Graciano Santos Neves Filho. Este clã familiar, juntamente com outras poucas famílias, compunha uma oligarquia poderosa na região.
} 
oito léguas da sede do município. Teve em mira o plantio de café, cultura em expansão na região sul e central da Província do Espírito Santo e que gerava grandes lucros.

Nesse local, foi aberta uma grande fazenda para o plantio do café e da cana-deaçúcar e também para a formação de pasto. Como a terra não era a mais propícia para o cultivo do café, por volta de 1870, procurou-se uma terra melhor para esse fim, localizando-se esta algumas léguas à frente, acarretando assim o surgimento da Fazenda Serra de Baixo ${ }^{18}$ (hoje município de Nova Venécia).

Conta-se que, tendo recebido de seus escravos e índios a informação da boa terra para o plantio de café mais a oeste, o major Antonio Rodrigues da Cunha deixou a sua fazenda na Cachoeira do Cravo, já com produção diversificada, indo em busca da nova terra fértil e promissora. Ao localizá-la, iniciou a abertura da mata virgem para a formação da primeira fazenda da região. O major Cunha denominou a nova terra de Serra dos Aimorés, devido a grande presença desses índios na região. A sua atuação entre esses índios, proporcionou-lhe posteriormente o título de Barão dos Aimorés.

Posteriormente, o major Cunha recebeu a companhia de seu irmão coronel Matheus Cunha, que fundou a Fazenda Boa Esperança (hoje município de Boa Esperança), localizada entre os rios Preto e Santo Izidoro, afluentes do São Mateus, e do major José Gomes Sodré, seu cunhado, que fundou a Fazenda Terra Roxa, conhecida como Fazenda da Gruta, situada próximo ao rio Preto, ampliando o núcleo populacional da região e, possibilitando assim, a chegada de novos imigrantes ${ }^{19}$.

A introdução da cultura do café em São Mateus associada à grande produção da farinha e ao comércio de escravos ocasionará a efetivação dessa oligarquia rural, a qual exercerá influência local e também junto ao Governo Provincial. Essa oligarquia fará suas ligações, geralmente através de casamentos, entre si ou com elementos de oligarquias do sul da província, o que veio a reforçar sua influência perante o Governo Provincial.

Neste contexto, a partir de meados do século XIX, registra-se o fortalecimento de uma oligarquia verdadeiramente mateense possuidora de patentes da Guarda Nacional coronéis, capitães, majores etc, dentre a qual registram-se fazendeiros que também

\footnotetext{
${ }^{18}$ Segundo informa o Padre Furbetta, em seu livro sobre a História da Paróquia de Nova Venécia, dos contatos entre os negros e os indígenas surgiu a descoberta da nova terra. In: MURARI et alli. História, Geografia e Organização Social e Política do Município de Nova Venécia. Prefeitura Municipal de Nova Venécia. Administração 1989-1992.

${ }^{19}$ MURARI et alli. História, Geografia e Organização Social e Política do Município de Nova Venécia. Prefeitura Municipal de Nova Venécia. Administração 1989-1992, p. 20.
} 
conquistaram títulos nobiliárquicos e se tornaram representantes regionais na Assembléia Provincial, como é o caso do Barão de Timbuí, que por três vezes foi deputado provincial. O Barão de Aimorés é considerado pioneiro na introdução de equipamentos hidráulicos importados para a produção do açúcar, além de grande cafeicultor e proprietários de escravos. Ressalte-se que esta oligarquia rural assentava-se em bases nitidamente escravocratas.

Tabela 3: População do Espírito Santo e São Mateus - Anos: 1856 e 1872.

\begin{tabular}{|c|c|c|c|c|}
\hline Região/Local & 1856 & $\%$ & 1872 & $\%$ \\
\hline \multicolumn{5}{|l|}{ Norte } \\
\hline SãoMateus & 5.853 & 11,9 & 8.170 & 9,9 \\
\hline \multicolumn{5}{|l|}{ Centro } \\
\hline Serra & 10.326 & 21,0 & 12.671 & 15,5 \\
\hline Vitória & 16.971 & 34,6 & 24.459 & 29,8 \\
\hline \multicolumn{5}{|l|}{ Sul } \\
\hline Benevente & 7.499 & 15,3 & 8.488 & 10,4 \\
\hline Itapemirim & 8.443 & 17,2 & 28.177 & 34,4 \\
\hline Província do Espírito Santo & 49.092 & 100,0 & 82.137 & 100,0 \\
\hline
\end{tabular}

O cultivo do café trouxe, indiscutivelmente, novas possibilidades de desenvolvimento para toda a Província do Espírito Santo, passando a ser o principal produto de exportação a partir de 1854, sendo sua produção intensificada na década de $1870^{20}$.

Nesta conjuntura favorável, um dos primeiros fazendeiros a fazer investimentos no café nas terras a oeste foi Antonio Rodrigues da Cunha, o Barão de Aimorés, como já destacamos. A partir de sua fazenda, denominada Cachoeira do Cravo, onde já se cultivava cana-de-açúcar cuja produção era levada em canoas e embarcações de pequeno porte até o porto, o café passou a ser a nova divisa econômica em direção ao interior da região. A fazenda chegou a ter infra-estrutura para construir três

\footnotetext{
${ }^{20}$ Acerca disto podemos citar o estudo realizado por Anna Lúcia Côgo, a qual, a partir de uma minuciosa pesquisa nas fontes fazendárias e nos relatórios presidenciais da Província do Espírito Santo no século XIX, coloca em evidência a forte influência exercida pela expansão da cafeicultura regional sobre o crescimento das rendas provinciais a partir de meados do Oitocentos, quando também se destacou o aumento progressivo das demandas e dos recursos referentes às melhorias infra-estruturais necessárias ao processo de ampliação das fronteiras agrícolas capixabas. CÔGO, Anna Lúcia. História Agrária do Espírito Santo no século XIX: a região de São Mateus. Tese de Doutorado. FFLCH/USP, 2007
} 
embarcações de porte: o Santa Rita, o Maria e o Constância. ${ }^{21}$ Esses barcos transportavam açúcar, farinha e café, saindo da Barra do São Mateus para a Bahia ou para o Rio de Janeiro. O maior comprador era o Rio de Janeiro, mas Bahia e Vitória também se constituíam em mercados importantes para a produção mateense.

Sem embargo, a expansão cafeeira na província capixaba, implicou na expansão da escravidão e acarretou a formação de poucos, mas autênticos, grupos oligárquicos assentados na grande propriedade rural com base escravista. Não só no sul - devido à proximidade com a Corte e a influência da cafeicultura fluminense - mas também no norte da província, tanto na região de Linhares quanto em São Mateus.

No sul da Província, além da região polarizada por Itapemirim, encontramos também um núcleo em expansão a partir de 1870, sediado nas vilas de Iconha e Piúma, baseado na cafeicultura e nas ações de dois coronéis-vendeiros ${ }^{22}$, Antonio José Duarte e José Gonçalves da Costa Beiriz, ambos portugueses, sócios e proprietários da Firma Duarte e Beiriz, pilares de um grupo oligárquico com formação efetiva a partir de 1879 , embora não se possa afirmar que seja também de base parental, como a oligarquia mateense.

A Firma Duarte e Beiriz ${ }^{23}$ propulsionou o desenvolvimento da área urbana de Iconha, embora não "se pode afirmar que ela foi a única responsável pelo surgimento da vila, mas a sua contribuição para tanto é inquestionável [...] No entanto não consistiu em uma sociedade premeditada do outro lado do atlântico e executada aqui. Faz-se necessário conhecer a trajetória desses dois imigrantes para compreendermos a formação da sociedade". ${ }^{24}$

Baseado em SIMÃO (1990:41), Caprini nos informa que o Coronel Beiriz possuía muitos escravos em sua fazenda em fins da década de 1860 e início de 1870, havendo também na região um quilombo chamado de 'Rancho dos Negros' que

\footnotetext{
${ }^{21}$ MURARI et alli. História, Geografia e Organização Social e Política do Município de Nova Venécia. Prefeitura Municipal de Nova Venécia. Administração 1989-1992, p. 18.

${ }^{22} \mathrm{O}$ termo coronel-vendeiro é utilizado por alguns pesquisadores de história do Espírito Santo, a exemplo da historiadora Nara Saletto que o utiliza em seus trabalhos sobre a história agrária capixaba, especialmente a pequena propriedade e a imigração estrangeira. Os estudos partem da lógica da dependência do pequeno proprietário, na maioria imigrantes, em adquirir terras e produtos das casas comerciais e de pagá-las com a colheita do café, em relação aos proprietários destas casas, geralmente grandes latifundiários, enfocando aspectos econômicos e sociais, a partir de um sistema político de tipo 'coronelista'. v. SALETTO, Nara. Trabalhadores nacionais e imigrantes no mercado de trabalho no Espírito Santo (1888-1930). Vitória: EDUFES, 1996 e Transição para o trabalho livre e pequena propriedade no Espírito Santo. Vitória: EDUFES, 1996.

${ }^{23}$ v. CAPRINI, Aldieris B. A. O comércio como propulsor do poder político em Iconha: o Coronel Antonio Duarte (1889-1915) Dissertação de Mestrado. Vitória:UFES/PPGHIS, 2007.

${ }^{24}$ Ibidem, p.62 e 86.
} 
abrigava fugitivos da região de Itapemirim. Faz referências a uma descrição sobre uma colônia inglesa implantada na mesma região na década de 1860, que utilizava escravos no desbravamento e no plantio de café e destaca ainda uma outra informação fornecida retirada de um documento descoberto recentemente - uma carta de 1883, escrita pelo Coronel Duarte a um comerciante da vila de Itapemirim, a qual se refere a um fazendeiro de Iconha que estava vendendo uma escrava. Na carta o Coronel Duarte justifica que ele 'não a compra [a escrava] por não necessitar, mas se o comerciante desejar adquiri-la o proprietário da escrava inclusive a troca por cachaça'25. Através deste exemplo peculiar, podemos fazer idéia da dinâmica comercial dos coronéisvendeiros a qual envolvia escravos e imigrantes, produtos da casa, sacas de café e terras numa teia de negociações que proporcionava ao coronel uma clientela política através do comércio.

\section{A política de parentela}

O mais comum nas formações oligárquicas brasileiras no período estudado, era o casamento entre parentes, com base em combinações no interior da família, prática esta que remonta aos tempos coloniais e a Portugal. Podemos afirmar que no Brasil o casamento endogâmico verificado entre as elites, consolida a propriedade rural, no contexto de um sistema de herança baseado na partilha, já que esta tende a fragmentar a propriedade entre os descendentes diretos. Suas implicações patrimoniais transformam a parentela num grupo quase-corporativo ${ }^{26}$.

Embora associada com a República Velha (1889-1930), a oligarquia agrária no Brasil surgiu e cristalizou-se no Segundo Reinado (1840-1889), sendo que as suas raízes econômicas assentavam-se geralmente na economia agroexportadora, embora o setor comercial, em muitas regiões, também se destacasse a ponto de exercer influência política significativa.

\footnotetext{
25 O documento encontra-se sob a guarda do Instituto Histórico e Geográfico de Iconha. v. CAPRINI, Aldieris B. A. Troca-se escrava por cachaça: presença da escravidão em Iconha (ES) -1883. Revista Eletrônica Cadernos de História. vol. VII, ano 4, n.1, julho de 2009, p. 150-151.

${ }^{26}$ LEWIN, Linda. Política e Parentela na Paraíba - um estudo de caso da oligarquia de base familiar. R.J., Ed. Record, 1987.
} 
Ao sentido original do termo oligarquia - governo em que a autoridade está na mão de poucas pessoas - juntou-se no Brasil um significado mais específico, além das conotações de poder econômico e político, que é o de governo baseado na estrutura familiar patriarcal, geralmente assentada na grande propriedade da terra. Sendo assim, o conceito no Brasil encontra-se intimamente ligado à idéia de mundo agrário e propriedade rural.

Durante o Segundo Reinado são introduzidas na esfera pública dos municípios famílias poderosas e extensas, os chamados 'clãs parentais'(na expressão de Oliveira Vianna) que transformar-se-iam em 'clãs eleitorais' ${ }^{27}$. Nessa conjuntura, abre-se espaço a nível local para o surgimento do coronelismo e do clientelismo, baseados em relações de parentela. Para Maria Isaura de Queiroz, a parentela, além de grupo econômico, era também um grupo político, cuja solidariedade interna garantia a lealdade dos membros para com os chefes ${ }^{28}$.

Um chefe partidário local, geralmente um coronel da Guarda Nacional, atuava localmente como o intermediário entre os interesses das famílias poderosas - da parentela - e o governo central. O detentor do título geralmente era proprietário rural, entretanto, havia coronéis que pertenciam a outras classes sociais, tais como médicos, comerciantes, padres, advogados etc. Pois a grandeza do título se concentrava nos aspectos econômicos e políticos e não na questão do comando, ou seja, o coronel era aquele que monopolizava o poder público, utilizando-se de sua influência política e poder pessoal, podendo também os capitães e os majores possuir a mesma autoridade simbolizada pelos coronéis.

Neste contexto, a parentela do comendador Antonio Rodrigues da Cunha, pai do Barão de Aimorés, proporciona uma excelente exemplificação, porque além de elucidar o papel da propriedade territorial, fornece também as características da organização de parentesco de elites do Espírito Santo, mantendo a identidade da família extensa como unidade coordenada. A reconstrução da história da família Cunha através de três gerações confirma a importância das estratégias matrimonias endogâmicas, assim como torna facilmente compreensível a rápida cristalização da sua rede de influência política regional.

\footnotetext{
${ }^{27}$ OLIVEIRA VIANNA apud LEWIN.

${ }^{28}$ QUEIROZ, Maria Isaura Pereira de. O mandonismo local na vida política brasileira e outros ensaios. S. P.: Alfa-Ômega, 1976.
} 
Quando da formação da vila de São Mateus em 1764, já existia no povoado quatro membros da família Cunha e dois da família Gomes dos Santos ${ }^{29}$. Da fusão dessas duas famílias surgiu a família Gomes da Cunha, cuja árvore genealógica tem por princípio o casal Antonio Rodrigues da Cunha (nascido em 1793 e falecido em 1863) e dona Rita Maria da Conceição Gomes da Cunha (falecida na década de 1870), pais do Barão de Aimorés.

Antonio Rodrigues da Cunha era proprietário da Fazenda São Domingos, situada à margem do rio São Domingos, afluente do rio São Mateus. Segundo relatos, essa fazenda tinha engenho de cana-de-açúcar, casa de farinha de mandioca, chamada regionalmente de 'bolandeira', criação de gado e de cavalos. Toda a produção de açúcar e de farinha era exportada em barcos à vela, de propriedade da fazenda para a firma Faria Cunha, estabelecida no Rio de Janeiro. Esta firma era composta pelos sócios Manoel José de Faria e Reginaldo Gomes da Cunha, respectivamente, genro e filho de Antonio Rodrigues da Cunha ${ }^{30}$.

Próximo à Fazenda São Domingos se aquilombaram os negros liderados por Silvestre Nagô e por Negro Rugério. Dona Rita da Conceição Cunha era considerada a maior proprietária de terras da Vila da Barra de São Mateus (atual Conceição da Barra), sendo também uma das maiores produtoras de farinha de mandioca da província, graças ao bom relacionamento com o quilombo liderado pelo Negro Rugério, também conhecido como Quilombo de Santana. Negociava farinha com os quilombolas e somente após a sua morte, em fins da década de 1870, o Quilombo foi destruído (em 1884).

Segundo Nardoto,

Dona Rita Cunha era quem exercia o controle do partido de oposição ao Império, apesar do seu marido ser quem controlava o partido do Imperador, em São Mateus. É bom lembrar que mulher nem votava naquela época. Dona Rita também possuía muitos escravos e um deles, o Negro Rugério, aquilombou-se em suas terras, na localidade de Santana, em Conceição da Barra. Através de um acordo o Quilombo produzia farinha para Dona Rita exportar e recebia proteção. [...] Os descendentes dessa senhora, inclusive Eduardo Durão Cunha, historiador já citado, contam que aos domingos se sentava à saída da Igreja Matriz, com seus 120

\footnotetext{
29 Os quatro nomes da família Cunha são os seguintes: Antonio Rodrigues da Cunha; João Ozório da Cunha; Luiz Fernandes da Cunha e Domingos da Cunha. Os dois nomes da família Gomes dos Santos, são os seguintes: Ignácio Gomes dos Santos e João Gomes dos Santos. Estes nomes constam entre as assinaturas dos habitantes do termo de lavratura da criação da Villa Nova de Sam Mateus, em 1764. In: NARDOTO, Eliezer e LIMA, Herinéia. História de São Mateus. São Mateus: Edal,1999.

${ }^{30}$ JORNAL DE SÃO MATEUS, $n^{\circ}$. 465, de 20/09/2001.
} 
quilos, com cordões e pulseiras de ouro pendurados, para distribuir patacas (moedas) para a garotada que lhe vinha pedir a benção. Depois da morte de Dona Rita as "Forças do Governo" invadiram o quilombo do Negro Rugério e destruíram tudo, matando muitos negros ${ }^{31}$.

Esta citação é muito significante, pois traça um perfil da personalidade de Dona Rita, que é um dos pilares principais para a formação oligárquica em estudo. Confirmando as informações de seus descendentes, o escritor Maciel de Aguiar complementa que Dona Rita,

nunca foi rigorosa no trato com pretos incultos e preguiçosos [...] Dona Rita Cunha, presidente do Partido Liberal, e que fazia oposição ao próprio marido, Antonio Rodrigues da Cunha, presidente do Partido Conservador, era de 'muita habilidade política' e capaz de fazer acordo com os escravos fugidos, protegendo-os contra as capturas, e com isso ampliar sua produção de farinha de mandioca ${ }^{32}$.

Podemos concluir, portanto, que a "oposição liberal" exercida por Dona Rita era simbólica, visto que o Partido Conservador em São Mateus sempre foi muito fiel ao Imperador, antes ou após a morte do coronel Antônio Rodrigues da Cunha, em 1863, quando o partido passa para a liderança do filho, o futuro Barão de Aimorés, que, naquele momento era major da Guarda Nacional, mais conhecido por major Cunha. A oposição liderada por D. Rita fazia parte do jogo político mantido pela família, cujo centro do poder estava nas mãos do patriarca, necessitando assim de um equilíbrio político que só poderia ser conseguido através de uma tênue bipolaridade partidária. ${ }^{33}$

Antonio Rodrigues da Cunha, o pai, era a maior autoridade da região, sendo Comendador da Ordem de Cristo e da Imperial Ordem da Rosa, as duas maiores e mais importantes comendas do Império Brasileiro, e era também Comandante Superior da Guarda Nacional da Região Norte da província, com a patente de coronel. Ganhou notoriedade na província e bons contatos junto a Corte que, por sua vez, costumava

\footnotetext{
${ }^{31}$ NARDOTO, Eliezer e LIMA, Herinéia. História de São Mateus. São Mateus: EDAL, 1999, p. 41.

${ }^{32}$ Eduardo Durão Cunha. Apud AGUIAR, Maciel de. Os últimos Zumbis: a saga dos negros do Vale do Cricaré durante a escravidão. Porto Seguro: Brasil-Cultura, 2001, p. 66.

${ }^{33}$ Sobre esse assunto, nos relata muito bem o Presidente Pedro Leão Velloso em 1859, ressaltando que: "Não temos que lastimar n'esta província, a existência de facções violentas, que, n'outras, tem sulcado profundas scisões, e gerado rancorosos ódios; podemos ainda asseverar, sem medo de errar, que não há aqui partidos políticos.[...] N'uma ou n'outra localidade notão-se divergências, mais ou menos pronunciadas, nascidas de pretensões individuaes, e ciúmes de influência; as quaes não embaração a acção da authoridade, e accesas nas quadras eleitorais, quase que de todo chegão a apagar-se, passado o calor da batalha”. Relatório de 25/02/1859. Biblioteca Digital do APEES.
} 
privilegiar os maiores proprietários rurais de cada região. Como político, notabilizou-se por ter apoiado a separação de São Mateus de Porto Seguro e o retorno ao Espírito Santo. Com tais poderes, podemos ter uma dimensão da influência de sua proteção às ações de sua esposa Dona Rita junto ao Quilombo de Santana. Tanto foi que só após a sua morte e a de Dona Rita é que o quilombo foi desmantelado pelas forças do governo, em 1884, como já nos referimos.

A partir da década de 1850, a ordem estratificada da sociedade brasileira começava a dar formas visíveis à prática clientelista, mobilizando os indivíduos inseridos dentro dessa ordem a ações voltadas para tal prática. O sistema clientelista baseava-se fundamentalmente na família, unidade básica da sociedade.

Nesta conjuntura, Antonio Rodrigues da Cunha, o Comendador, que ocupava uma posição oficial da Guarda Nacional, não constituiu uma exceção à regra: com os recursos de ser líder de uma numerosa prole de doze filhos, consolidou-se como o pilar de um bem estruturado sistema sócio-econômico com base escravista e na propriedade da terra e amparado numa formação política de tipo coronelista. ${ }^{34}$

A posse de terras e de escravos influenciava diretamente na formação de uma clientela.

\begin{abstract}
A família e a unidade doméstica constituíam os fundamentos de uma estrutura de poder socialmente articulada, e o líder local e seus seguidores trabalhavam para ampliar essa rede de dependência. Numa sociedade predominantemente rural, um grande proprietário de terras contava com a lealdade de seus trabalhadores livres, dos sitiantes das redondezas e dos pequenos comerciantes da vila, lealdade que seria demonstrada por várias maneiras, não menos pelo apoio nas eleições ${ }^{35}$.
\end{abstract}

Sabemos que é fato consumado na história do Brasil agrário, o poder dos grandes latifundiários sobre seus dependentes, e de suas alianças com outros proprietários por meio de laços familiares. E também, que as autoridades em geral eram muito sensíveis aos interesses agrários, isto quando não eram elas próprias proprietárias de terra e de escravos, o que reforça os laços de ajuda mútua.

\footnotetext{
${ }^{34} \mathrm{O}$ “coronelismo", por sua vez, é assentado em práticas paternalistas ou "clientelistas", sendo ainda esse clientelismo 'baseado em noções de obediência e lealdade, e significou tanto o preenchimento de cargos governamentais quanto a proteção de pessoas humildes, mesmo os trabalhadores agrícolas sem terra' Cf. GRAHAM, Richard. Clientelismo e Política no Brasil do século XIX. R.J.: Ed. UFRJ, 1997.

${ }^{35}$ Ibidem, p. 17.
} 
Os Gomes da Cunha são exemplos, visto que o comendador Antonio Rodrigues teve doze filhos com Dona Rita, e cinquienta e nove netos, sendo que praticamente todos os seus filhos se casaram com pessoas ligadas a famílias ascendentes economicamente, do século XX, com base em extensa parentela.

Entre estas famílias podemos citar os Santos Neves, os Gomes Sodré, os Esteves, os Abel de Almeida, os Faria Lima e os Silvares entre as principais, todas escravistas (retornaremos a essas famílias quando abordarmos os assuntos referentes à escravidão em São Mateus, baseados nos documentos cartoriais da época).

E, dentre os filhos do Comendador, a figura de Aimorés destacou-se mais, pois além de fazer fortuna e manter a influência política do pai, teve ainda onze filhos, os quais reforçaram o caráter oligárquico da família através de casamentos com elementos oriundos da grande propriedade rural, reafirmando assim o caráter das relações políticas, econômicas e sociais em bases parentais.

1.3. O perfil sócio-econômico: os escravos, o porto, a farinha e o café.

Segundo dados que constam em relatório de 1859, do Presidente Leão Velloso, da Província do Espírito Santo, baseado em dados enviados pela Câmara de São Mateus, existiam no município cerca de

\begin{abstract}
205 estabelecimentos agrícolas e industriais, sendo 152 fábricas de fazer farinha de mandioca, 48 de manipular café, duas serrarias, uma fábrica de fazer açúcar e aguardente e duas olarias de tijolos e telhas, sendo nove fábricas movidas por água e todas as mais por animais. Nesses estabelecimentos empregam-se perto de 2.800 indivíduos livres e escravos. Os principais ramos de produção e exportação são a farinha de mandioca e o café - e o Rio de Janeiro o principal centro das relações comerciais $^{36}$.
\end{abstract}

Estes dados nos remetem ao historiador capixaba Renato Pacheco, que costumava lembrar que a farinha de mandioca de São Mateus era muito procurada nos mercados do Rio de Janeiro, chegando a contar com cotação própria e possuindo um preço mais elevado que a farinha de outras regiões do país.

\footnotetext{
${ }^{36}$ Relatório do Presidente da Província do Espírito Santo Pedro Leão Velloso (25/05/1859), “Appenso M - Câmaras Municipaes". Biblioteca Digital do Arquivo Público do Espírito Santo.
} 
Assim como a farinha de mandioca, o comércio negreiro em São Mateus também sempre se apresentou com prosperidade acarretando, inclusive, a formação de empresas especializadas nesse tipo de comércio.

Conforme nos informa Cunha,

\begin{abstract}
A chegada de um negreiro, ao porto de São Mateus era uma verdadeira festa. A população ali estava toda reunida, compradores e curiosos. Tudo era movimento (...) Devidamente desembarcados, os negros acorrentados em fila indiana, eram tangidos até o mercado. Ali eram examinados por sua compleição física e até origem tribal ${ }^{37}$.
\end{abstract}

Baseado nas informações e dados gerais fornecidos pela documentação cartorial de São Mateus, acerca da escravidão entre 1863 e 1888, constatamos o registro cartorial de 15 empresas (firmas) que comercializaram escravos em São Mateus neste período ${ }^{38}$. Observando a relação dessas empresas, percebemos que cinco sobrenomes aparecem com destaque dentre os comerciantes de escravos na região, na seguinte proporção: Fundão (aparece em 4 empresas), Faria ( 2 empresas), Rios (3 empresas), Almeida (2 empresas) e Guimarães (3 empresas). Os outros sobrenomes aparecem somente com uma incidência (ou seja, apenas em uma empresa): Veiga, Morgado, Gaiato, Cunha, Fonseca, Bastos, Simões, Lopes, Ferreira e Alves.

Em observações de documentos do Fundo Fazenda (do Arquivo Público do Espírito Santo/APEES) sobre São Mateus na segunda metade do século XIX, podemos observar um considerável volume de transações comerciais envolvendo escravos, e grande parte delas eram registradas devido ao recolhimento de impostos e taxas. Isto ocorria nas seguintes situações: compra e venda de escravos, transmissão de escravos, exportação e importação dos mesmos, escravos a jornal, escravos de ganho, dentre outros. Nesse sentido, consideramos bastante significativa a ocorrência contínua do item 'exportação de escravos', assim como o volume de impostos arrecadados sobre esse tipo de transação. Ou seja, uma região que chega a 'exportar' escravos devia dispor de um razoável número dos mesmos para esse tipo de atividade.

\footnotetext{
${ }^{37}$ CUNHA, Eduardo Durão. “São Mateus e sua História”. Revista São Mateus 450 anos, EDAL: São Mateus, 1994. Embora esse relato seja provavelmente baseado na literatura local e em histórias orais, ele ilustra bem a possível movimentação comercial do porto em alguns momentos.

${ }^{38}$ Alves, Ferreira \& Cia; Faria \& Bastos; Fonseca, Rios \& Cia; Fundão \& Irmãos; Faria, Cunha \& Cia; Fundão Júnior \& Cia; Guimarães, Gaiato \& Cia; José Joaquim Almeida Fundão \& Cia; Leonel Joaquim de Almeida Fundão \& Cia; Luis José dos Santos Guimarães \& Cia; Morgado, Rios, Guimarães \& Cia; Rios \& Cia; Veiga \& Cia; Simões, Faria \& Cia e Joaquim Lopes \& Irmão.
} 
Tal assertiva nos remete vagamente a algumas deduções presentes na história oral da região, segundo a qual existiam fazendas reprodutoras de escravos em São Mateus, citando como exemplo o caso da Fazenda Boa Esperança ${ }^{39}$.

Várias são as evidências da importância da escravidão em São Mateus, as quais podem ser encontradas tanto nas fortes manifestações de resistência à escravidão, tais como a formação de um considerável número de quilombos na região e do enfrentamento de escravos com os seus senhores proprietários, como também a existência de um expressivo movimento abolicionista regional.

A evidência da grande presença dos negros e da importância da escravidão em São Mateus pode ser constatada ainda nos levantamentos recentes dos territórios das comunidades remanescentes de antigos quilombos no Brasil, onde aparece a região de São Mateus e Conceição da Barra como os locais de maior incidência e concentração de quilombos no território do Espírito Santo. Para os moradores das comunidades remanescentes de quilombos, especialmente em São Mateus e Conceição da Barra, "as transformações advinda do regime de uso do espaço, modificaram as formas tradicionais pelas quais eles tinham acesso à terra". Neste contexto, e "diante das dificuldades de acesso às informações e o desconhecimento das leis em vigor à época, muitos ocupantes deixaram de requerer seu título de domínio ao Estado do Espírito Santo, continuando na condição de posseiros e sujeitos a perderem seus direitos". ${ }^{40}$

As comunidades da região conhecida como Sapê do Norte, que engloba os municípios de Conceição da Barra e São Mateus, é um exemplo destacado dessas comunidades. Segundo Silva, esta região, "caracteriza-se pela relação entre sociedade e meio ambiente que pode ser traduzida por formas tradicionais de ocupação, resistência étnica, trato com a terra, ciclos festivos, organização religiosa [...] como um território

\footnotetext{
${ }^{39}$ Esta informação foi fornecida oralmente pelo escritor Maciel de Aguiar, embora ele não apresente documento comprobatório em seu trabalho Os últimos Zumbis: a saga dos negros do Vale do Cricaré durante a escravidão. Porto Seguro: Brasil-Cultura, 2001.

${ }^{40}$ Cf. SILVA, Sandro José da. Quilombolas no Espírito Santo: identidade e territorialidade. Dimensões Revista de História da UFES, n.18, 2006, p. 272 - 300. Silva corrobora a idéia de que "o norte do Espírito Santo (especialmente São Mateus e Conceição da Barra) caracteriza a ocorrência do movimento de resistência à opressão, por parte dos escravos e escravos libertos, alforriados e finalmente livres na margem direita do Rio São Mateus - Cricaré, para os moradores da região -, descrita na literatura local. Embora a ênfase desses estudos aponte a fuga como elemento central na Configuração das Comunidades de Quilombo, a compra de terras caracterizou as atividades de algumas famílias na região, como é possível ver no Censo Agrícola de 1920 [...].” Op. cit., p. 297 e 278.
} 
étnico - confluência entre ocupação histórica ligada a escravidão e a formação de uma identidade quilombola". ${ }^{41}$

A herança dessas comunidades e sua influência em São Mateus ainda hoje reafirmam as suas origens, mantendo vivas a história e a cultura do seu povo.

Em Os Últimos Zumbis, o escritor Maciel de Aguiar ${ }^{42}$ versa sobre a formação social e econômica dos quilombos em São Mateus, a qual, segundo ele, variava pouco variação esta que ocorria em função dos diferentes líderes que se destacavam na organização dos quilombolas. No geral, mantinham uma forma de organização cooperativista, a qual possibilitava uma "economia de abundância". Adotavam a economia de subsistência, de pequenos roçados, onde produziam "de tudo" (agricultura diversificada) para o sustento de suas famílias e das criações (economia "familiar").

Outro fato importante, e que também contribui para confirmar as evidências apontadas, é que na região de São Mateus registrou-se a apreensão do último navio negreiro clandestino que circulou na costa brasileira (1856), após a promulgação da lei de 1850 proibindo o tráfico de escravos africanos para o Brasil. ${ }^{43}$

Enfim, entre estas e outras observações preliminares, podemos nos atentar para a possibilidade de um comércio rentável de escravos em São Mateus.

Segundo Durão Cunha,

Os latifundiários da região, costumeiramente faziam à Igreja, doações de novilhas, garrotes e também de escravos. Estes, ou eram revendidos a preço corrente [...] ou ficavam prestando serviço à paróquia. [...] Ressalte-se que, São Mateus e São Benedito, os padroeiros das duas igrejas locais, eram proprietários de um bom número de escravos africanos ${ }^{44}$.

Essa perspectiva nos induz a pensar que se os proprietários de escravos chegavam a fazer doações à Igreja é porque os tinham em grande quantidade. O nome do major Antonio Rodrigues da Cunha, figura como um dos maiores proprietários de escravos de São Mateus. Há registros de confissão de dívida em que fazendeiros hipotecaram em favor do Barão vários bens, inclusive escravos.

\footnotetext{
${ }^{41}$ Ibidem.

${ }^{42}$ No tópico intitulado "Farinha de mandioca e chicote". AGUIAR, Maciel de. Os últimos Zumbis: a saga dos negros do Vale do Cricaré durante a escravidão. Porto Seguro: Brasil-Cultura, 2001.

${ }^{43}$ PRADO JÚNIOR, Caio. História Econômica do Brasil. S.P.: Brasiliense, 1985. p. 152. A embarcação norte-americana Mary E. Smith (uma escuna) transportava 350 negros vindos da África, quando a embarcação Olinda (um brigue), da Marinha de Guerra do Brasil, o interceptou, sendo preso os traficantes e os negros levados para a Bahia. Foi detido em 20 de janeiro de 1856, na barra do Rio São Mateus. Essa informação de Prado Júnior é baseada em Perdigão Malheiros.

${ }^{44}$ CUNHA, Eduardo Durão. São Mateus e sua História. Revista São Mateus 450 anos, EDAL: São Mateus, 1994, p.31.
} 
Também o nome de Domingos Rocha da Silva Rios figura como um dos maiores compradores de escravos, e o de Constante Sodré, que foi governador do Estado, entre outros escravocratas.

A partir da década de 1860 verifica-se o crescimento das lavouras de café. Neste contexto, o mercado de escravos funcionava como algo essencial para a obtenção de mão-de-obra para a lavoura cafeeira, que a essa altura já passava a ocupar o primeiro lugar no âmbito da província do Espírito Santo. Além da produção da farinha de mandioca e da cana-de-açúcar, a cultura cafeeira demandou a absorção de mão-de-obra escrava, atuando também como elemento vivificador da economia e da sociedade mateense e espírito-santense em geral. Não tão acentuada como no sul e no centro da Província, a produção cafeeira no norte acaba por se impor à cana-de-açúcar, constituindo-se como uma alternativa a essa, porém continuou a farinha de mandioca sendo o principal produto regional.

Pesquisas recentes sobre a história agrária do Espírito Santo no século XIX, confirmam que mesmo com as rápidas mudanças observadas nos núcleos produtivos da região central e sul da província, onde o ritmo da expansão da economia cafeeira apresentou-se mais dinâmico, a região de São Mateus ao norte, manteve a tradicional produção da farinha de mandioca e seus derivados como sua principal atividade econômica no decorrer do século XIX, além de inserir-se, mesmo que lentamente, nos quadros da produção cafeeira do Espírito Santo à época. ${ }^{45}$ Tal processo é constatado a partir de estudos feitos na documentação fiscal, onde o maior montante da arrecadação regional (impostos e taxas) incide sobre a produção da farinha e de seus derivados. No entanto, nas décadas finais do século XIX, observa-se que tal montante das receitas regionais passa a receber expressiva contribuição da exportação do café, cuja produção se apresentou em crescimento gradual na segunda metade do Oitocentos.

A historiadora Vilma Almada ${ }^{46}$ organizou um mapa destacando a distribuição irregular da população escrava pelas diversas regiões da Província onde se observa que, com exceção da região de São Mateus, a concentração de escravos coincide com a expansão do café. Isso a leva a concluir que foi a economia típica da 'plantation'

\footnotetext{
${ }^{45}$ CÔGO, Anna Lúcia. História Agrária do Espírito Santo no século XIX: a região de São Mateus. Tese de Doutorado. FFLCH/USP, 2007

${ }^{46}$ ALMADA, Vilma Paraíso F. de. Escravismo e Transição: o Espírito Santo (1850-1888). R.J.: Graal Edições, 1984.
} 
cafeeira o que caracterizou majoritariamente, no Espírito Santo, as relações de produção no processo de apropriação do trabalho escravo na segunda metade do século XIX.

Tabela 4: Distribuição da população escrava na Província do Espírito Santo por regiões (1824 -1876)

\begin{tabular}{llllllllllll}
\hline Anos & S. Mateus & $\%$ & Capital & $\%$ & \multicolumn{1}{l}{$\begin{array}{l}\text { Reis } \\
\text { Magos }\end{array}$} & $\%$ & Itapemirim & $\%$ & $\begin{array}{l}\text { Total } \\
\text { escravos } \\
\text { Província }\end{array}$ & na \\
\hline 1824 & 2.654 & 20,1 & 7.142 & 54,2 & 265 & 2,0 & 3.127 & 23,7 & 13.188 & 100,0 \\
1856 & 2.213 & 18,0 & 4.923 & 40,1 & 752 & 6,2 & 4.381 & 35,7 & 12.269 & 100,0 \\
1872 & 2.813 & 12,5 & 6.919 & 30,7 & 1.098 & 4,8 & 11.722 & 52,0 & 22.552 & 100,0 \\
1875 & 2.617 & 12,6 & 6.079 & 29,2 & 635 & 3,0 & 11.516 & 55,2 & 20.847 & 100,0 \\
1876 & 2.500 & 12,0 & 5.839 & 28,0 & 614 & 3,0 & 11.853 & 57,0 & 20.806 & 100,0 \\
\hline
\end{tabular}

Neste contexto, o norte da província apresenta-se menos influenciado pelo café no período estudado. São Mateus aparece como tradicional produtor e exportador da farinha de mandioca, enquanto Linhares, Santa Cruz e Nova Almeida dedicam-se quase que exclusivamente à extração de madeira. A partir dessas análises, a autora afirma que a região compreendida pelas comarcas dos Reis Magos e São Mateus, apesar da tentativa inicial, não se implantou o cultivo do café e a população cresceu muito pouco entre 1856 e 1872. A comarca de São Mateus não foi incentivada pelo surto cafeeiro e sua economia se manteve sem crescimento, produzindo praticamente o mesmo número de alqueires de farinha de mandioca exportada. Segundo Almada, esta região apresenta uma diminuição em seu número de escravos nesse período.

\begin{abstract}
A Comarca de São Mateus, tradicionalmente dedicada à produção e exportação de farinha de mandioca, contava em 1856 com $18 \%$ dos escravos da Província, caindo essa porcentagem para 12\% em 1872. Não incentivada pelo surto cafeeiro, a sua economia se manteve estacionária,

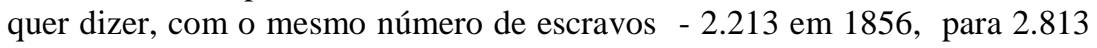
em 1872 - e produzia praticamente o mesmo número de alqueires de farinha

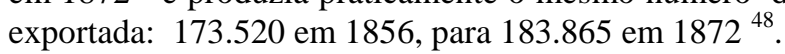

\footnotetext{
${ }^{47}$ Dados extraídos das seguintes fontes: - Memória Statística da Província do Espírito Santo escrita no anno de 1828 por Ignácio Accioli de Vasconcelos (APEES); - Censo Local, apresentado à Assembléia Legislativa pelo Presidente Joaquim Marcelino da Silva Lima, em 25 de maio de 1857 (APEES); - Censo de 1872/Brasil: Diretoria Geral de Estatística; - Brasil: D.G.E. Relatórios e Trabalhos Estatísticos apresentados ao Ministro e Secretário de Estado dos Negócios do Império em 31 de dezembro de 1876.

48 ALMADA, Vilma Paraíso Ferreira de. Escravismo e Transição: o Espírito Santo (1850-1888). R.J.: Edições Graal, 1984. p.70. Dados retirados dos Relatórios dos Presidentes da Província de 1852 e de 1874.
} 
Devemos observar, entretanto, que a afirmativa de Almada de que a economia mateense se manteve estacionária neste período, baseia-se na comparação que estabelece com a região sul da província, cujo desenvolvimento econômico atingiu cifras bem maiores, principalmente em relação ao aumento da população escrava. Isto não quer dizer que São Mateus estivesse sem apresentar níveis de desenvolvimento econômico nesta época, tendo em vista que os números relativos à população escrava demonstram um aumento de $27 \%$ aproximadamente do contingente no período de 16 anos.

\subsection{As vias de comunicação.}

O desenvolvimento agropecuário e mercantil de São Mateus foi facilitado pelo rio, uma via permanente com a costa brasileira. $\mathrm{O}$ rio funcionava como hidrovia, foi $\mathrm{o}$ maior agente de integração do município de São Mateus com outras localidades.

O Presidente da Província do Espírito Santo, José Fernandes da Costa Pereira Jr., ao comentar, em 1862, sobre o potencial dos rios da província, faz a seguinte descrição do rio São Mateus:

\footnotetext{
Este rio, primitivamente denominado Cricaré, vem da província de Minas, sendo pouco conhecido na sua origem. É navegável por barcos de 10 palmos de calado até dez léguas acima da foz e 2 da cidade, no lugar denominado Jacarandá. Dahi para cima a profundidade vai diminuindo, sendo, porem sufficiente para canoas de pequena lotação até 8 léguas. $O$ vapor da companhia Espírito Santo navega sem dificuldades da Barra a cidade de São Matheos. A barra tem regularmente 12 palmos de profundidade no preamar. Os principais afluentes d'este rio são: Sant'Anna, S. Joaquim, o Mariricú e o Preto, aquelles à margem esquerda e os dois últimos à direita. ${ }^{49}$
}

Além das embarcações a vela que faziam o comércio com as províncias vizinhas, São Mateus tornou-se escala obrigatória dos vapores, quando se iniciou a navegação regular no Espírito Santo. O movimento do porto intensifica-se, especialmente a partir da autorização da navegação regular a partir de 1850. Entre as embarcações mais citadas

\footnotetext{
${ }^{49}$ Relatório de Presidente da Província do Espírito Santo José Fernandes da Costa Pereira Jr. (25/05/1862, p. 70). Biblioteca Digital do APEES.
} 
que aportavam por lá, destacam-se os vapores das Cia Espírito Santo e Caravelas, da Miranda e Jordão \& Cia, navios do Lhoyd Brasileiro, que aportavam com uma regularidade quinzenal. ${ }^{50}$

A partir de 1850, novas alternativas de comunicação são tentadas, como por exemplo, com o interior de Minas: uma 'picada' de São Mateus, unindo este município à região do Peçanha, em Minas, atravessando todo o sertão norte da província do Espírito Santo. Porém este caminho não passou de uma entrada exploratória, tanto que, em 1872 o presidente da província Gabriel de Paula Fonseca, informava nada poder adiantar sobre a mesma e sugeria uma saída de São Mateus através das nascentes do rio de mesmo nome e daí até Filadéfia (região da atual Teófilo Otoni) em território mineiro ${ }^{51}$.

A iniciativa particular foi muito importante no trabalho de aberturas de vias de comunicação, ou desbravamento de caminhos, que posteriormente tornaram-se estradas. O major Antonio Rodrigues da Cunha é citado como pioneiro na abertura da picada do Peçanha, por volta de 1871. A região do Peçanha (Descoberto do Peçanha) em Minas interligava São Mateus à região do Serro, pondo assim em comunicação as duas províncias. Esta região fica no vale do rio Suaçuí, rio que deságua no rio Doce (em área próxima ao atual município de Governador Valadares), não distando muito das nascentes do rio São Mateus em Minas, na região do Alto São Mateus. A notícia desta conquista mereceu nota no "Jornal do Comércio" de Minas:

[...] O Espírito Santo existe aí ao pé de nós, apenas separado por uma mata de facílima penetração; por não haver um pequeno sacrifício para comunicar com nossos irmãos vizinhos, precisamos demandar ao Rio de Janeiro [...] Aberta a nossa comunicação com São Mateus, poderemos augurar um futuro lisonjeiro para esses lugares: estaremos apenas a cinqüenta léguas do litoral. O Pessanha será ponto de passagem para todos os negociantes de Diamantina, Serro, Penha e São João ${ }^{52}$.

Embora de penetração não tão fácil assim, como nos relata o jornal mineiro e reitera o presidente da Província do Espírito Santo, muito pelo contrário, de dificílima

\footnotetext{
50 NARDOTO, Eliezer \& LIMA, Herinéia. História de São Mateus. São Mateus: EDAL, 1999, p.50.

${ }^{51}$ ROSA, Lea B. de Alvarenga. Condições da Província do Espírito Santo - Primeiros Caminhos de Minas Gerais. Vitória:Ed. Instituto Histórico (IHGES), 1999, p. 9.

${ }^{52}$ Extraído do Relatório lido no Paço d'Assembléia Legislativa da Província do Espírito Santo pelo Presidente o Exmo. Sr. Doutor Francisco Ferreira Corrêa; na sessão ordinária do ano de 1871. In. BICHARA, Terezinha Tristão. História do Poder Legislativo do Espírito Santo/ 1835-1889. vol. 1. Vitória, 1984. p. 282.
} 
penetração devido à forte presença de índios Botocudos até o último quartel do século XIX - principalmente os Giporoks (botocudos 'maus' ou 'bravos') concentrados no 'centro da mata' e nos altos de serra das vertentes do São Mateus, ou Alto São Mateus (região localizada acima das matas do norte do rio Doce) - a necessidade de aberturas de rotas comerciais terrestres se impunha ao perigo das matas.

Desde 1853 encontramos informações sobre a possibilidade de abertura de uma estrada que estabeleça a ligação do Espírito Santo com Minas Gerais pelo norte capixaba, a qual ligaria a cidade de São Mateus ao Serro e que muito benefício traria para as duas províncias. ${ }^{53}$

Em relatório datado de 1854, o então presidente da Província do Espírito Santo, Sebastião Machado Nunes, informa a situação da picada que está sendo aberta, para a ligação do Espírito Santo com Minas, através da região norte capixaba:

\begin{abstract}
Muito tempo há que se projeta estabelecer uma comunicação entre a comarca do Serro em Minas, e a de São Matheus desta província. Informovos com prazer que já se deu princípio aos trabalhos próprios para se conseguir este importante melhoramento de incalculável vantagem para aquella como para esta província. [...] Em data de 3 de março do anno p.p. foi por ordem do Exm. Presidente de Minas celebrado um contracto com o major João Baptista Dias e o capitão Remígio Elceto de Souza para a abertura de uma picada transitável por cavalleiros e cargueiros, partindo da freguezia do Pessanha até o primeiro povoado à margem do rio São Matheus. [...] Em data de 3 de julho do mesmo anno tinha informado o emprezario Dias que a dita picada achava-se aberta até o rio Suassuhy, sendo provável que hoje se ache muito mais adiantada, porque me consta que estes trabalhos tem progredido. ${ }^{54}$
\end{abstract}

O presidente conclui seu relatório fazendo uma análise da situação das estradas da província, realçando a necessidade da ligação com Minas:

Abrir comunicações novas, e melhorar as existentes para facilitar a condução dos productos da lavoura aos portos do littoral, é, como sabeis, a maior necessidade da época. A estrada de São Pedro D'Alcântara, a de Santa

\footnotetext{
${ }^{53}$ Relatório do Presidente da Província do Espírito Santo Evaristo Ladislau e Silva, de 23/05/1853. Biblioteca Digital do APEES. O presidente observa também que, além da picada para o Serro, já determinou o início "dos trabalhos de abertura do canal de Itaúnas em São Mateus, e do Una na Serra para os quaes aplicou a quantia de quatro contos de réis [...] e [frisando de que] convenço-me de que serão vencidos os obstáculos que forem aparecendo às comissões que nomeei dos cidadãos José Barbosa Meirelles, Marcellino Vieira Machado, Joaquim Pereira de Aguiar, Antonio Rodrigues da Cunha, Manoel Ribeiro Silvares e Roque José Gomes para a realização dos mesmos trabalhos", cujo resultado será de muita vantagem para a Província.

${ }^{54}$ Relatório do Presidente da Província do Espírito Santo, Sebastião Machado Nunes (25/05/1854, p. 41). Biblioteca Digital do APEES.
} 
Thereza, e essa outra que se projecta no município de São Mateus são as principais, de que a província tem uma necessidade imperiosa. ${ }^{55}$

Contudo, finaliza o presidente, é necessário também efetuar melhorias em outras picadas já existentes, as quais têm relação direta com as três principais estradas citadas, inclusive "a que comunica o município de São Matheus com os que lhe ficão do Sul, a qual se acha muito arruinada". ${ }^{56}$

Outro presidente da Província do Espírito Santo, Nascentes D’ Azambuja, em 1852 destaca em relatório ser da maior importância "uma estrada que communique directamente pelo sertão a Villa de Linhares com a Cidade de São Matheus, por ser este o único meio de levantar a mesma Villa do atrazo e abatimento em que está", não obstante o potencial que tem para se tornar uma das mais importantes da Província ${ }^{57}$.

Nesse sentido ordenou à Câmara Municipal de Linhares a promoção de explorações dos sertões para encontrar a melhor direção que tal estrada deverá tomar e também já colocou esta obra como uma das prioridades da província. ${ }^{58}$

Já o presidente Leão Velloso, ao analisar a precariedade das vias de comunicação da província, observa que "a população foi se aglomerando à beira do mar, e dos rios navegáveis, e à fazer por água sua comunicação, e transporte de productos". Dessa forma não se cuidou de abrir estradas, já que não se precisava das mesmas. Afirma que a província não possui nenhuma estrada, "além das picadas abertas no desígnio de chamar para aqui o commercio de Minas Geraes; o mais não passa de caminhos vizinhaes". ${ }^{59}$

A partir de 1856, houve algum comércio entre São Mateus e Santa Clara, às margens do rio Mucuri - porto onde a navegação deste rio permitia embarcações a vapor até o mar, até São José do Porto Alegre (atual município de Mucuri no Extremo Sul da Bahia).

Santa Clara, fazenda situada às margens do rio Mucuri, distava aproximadamente oito léguas do mar, e localizava-se em terras consideradas pertencentes ao termo de São

\footnotetext{
${ }^{55}$ Relatório do Presidente da Província do Espírito Santo Sebastião Machado Nunes (25/05/1854, p. 45). Biblioteca digital do APEES.

${ }^{56}$ Ibidem.

${ }^{57}$ Relatório do Presidente da Província do Espírito Santo Nascentes D’ Azambuja (24/05/1852. p. 44). Biblioteca Digital do APEES.

${ }^{58}$ Ibidem.

59 Relatório do Presidente da Província do Espírito Santo Pedro Leão Velloso (25/02/1859, p. 45). Biblioteca Digital do APEES.
} 
Mateus. Era um entreposto comercial situado a caminho de Nova Filadélfia (atual município de Teófilo Otoni), também às margens do Mucuri no interior mineiro. Era produtora de gêneros de subsistência e criadora de gado vacum.

Sobre o percurso entre São Mateus e Santa Clara, nos informa o relatório do vice-presidente da Província do Espírito Santo, Barão de Itapemirim:

Foi aberta uma picada da cidade de São Matheus com direção a Santa Clara, e não posso deixar de consignar aqui o nome do tenente coronel Matheus Antonio dos Santos a cujos esforços se deve principalmente a exploração desta importante estrada, em cujos trabalhos foi guiado pelo engenheiro da companhia Mucury, o Sr. Charles Bernard. ${ }^{60}$

Segundo informações passadas pelo referido tenente coronel, foram gastos dez dias de viagem em função do processo de medição da referida picada, mas que em situação normal gasta-se de três dias e meio até a cidade. Itapemirim observa ainda que a estrada deve atravessar o rio Itaúnas (o qual segue 12 léguas numa largura de 16 a 25 braças e cuja profundidade permite a navegação a barcos que demandem 20 palmos de água), e devido a proximidade desse rio com Santa Clara, "a navegação fluvial vem offerecer todas as vantagens para uma communicação que tanto deve influir nos destinos d'aquella parte da nossa província", ${ }^{61}$

No relatório do presidente da província Costa Pereira Jr., de 1861, temos as seguintes as seguintes informações sobre a picada de Santa Clara:

Aberta em 1858 pelas diligencias do engenheiro Carlos de Bernard, dirigese da cidade de São Mateus, ao ribeiro de Pedras, affluente do Mucury, onde se entronca na estrada que vem de Santa Clara para Philadélfia, seguindo d'ahi para Minas Novas, onde a encontra a estrada geral do Rio a Bahia. [...] O fim a que se mirou com a abertura desta picada foi, ligar-se a cidade de São Matheus com a colônia do Mucury. ${ }^{62}$

A Colônia do Mucuri, assim como a Colônia Militar do Urucu - criada para a defesa de 'agressões' dos selvagens - e a Colônia D. Pedro II, todas no nordeste mineiro, foram criadas pela Companhia do Mucuri, cujo diretor, o político mineiro Teófilo Otoni,

\footnotetext{
${ }^{60}$ Relatório do Vice-Presidente da Província do Espírito Santo Barão de Itapemirim (25/05/1857, p. 2324). Biblioteca Digital do APEES.

${ }^{61}$ Ibidem.

${ }^{62}$ Relatório do Presidente da Província do Espírito Santo José Fernandes da Costa Pereira Júnior (23/05/1861, p. 52). Biblioteca Digital do APEES.
} 
projetou a abertura de rotas para possibilitar o fluxo de comércio entre a as povoações já bem estabelecidas na região - como o Peçanha e as freguesias adjacentes - com o vale do Mucuri. Os próprios moradores do Peçanha já haviam iniciado explorações e abertura de caminhos em direção ao Rio São Mateus, região onde algumas povoações já se estavam estabelecendo". 63

Sobre esse assunto o relatório do presidente Pereira de Barros, informa acerca do interesse manifestado pelo diretor da empresa do Mucuri, Teófilo Otoni, para o projeto dessa estrada, tendo colocado à disposição do governo provincial o engenheiro francês daquela companhia - Charles Bernard - o qual já se encontrava em São Mateus para acompanhar os trabalhos de abertura da referida picada. Cumpre agora "fazer continuar uma estrada de incalculáveis vantagens futuras, e que desde já fará agitar um grande commercio de gados entre o município de São Matheus e Minas Novas por intermédio de Philadelphia e Santa Clara no Mucury". ${ }^{64}$

A inexistência de outras vias terrestres de escoamento da produção agrícola aumentava o movimento no porto de São Mateus, especialmente após a autorização da navegação regular a partir da década de 1850, com subvenção ao empresário ou associação que mantivesse um pequeno vapor entre a Barra de São Mateus e São Mateus.

No contexto da navegação a vapor, o relatório do presidente da Província do Espírito Santo Evaristo Ladislau e Silva, registra a grande utilidade trazida por este tipo de navegação na província, e de "quanto interesse foi para a mesma província o contracto direto que o governo Imperial fez ultimamente celebrar e que já está em vigor para tocar o vapor em diversos portos desde Itapemirim a Mucury nas suas viagens de ida e volta do Rio de Janeiro a Caravellas". ${ }^{65}$

Sobre a navegação a vapor, o presidente Pedro Leão Velloso, registra que "as duas companhias - Mucury e Espírito Santo -, vão marchando regularmente; tendo sido, de fevereiro para cá, constantes nas viagens de seus dois vapores, sahindo do Rio de

\footnotetext{
${ }^{63}$ MISSAGIA, I. Mattos. A colonização "étnica” do Mucuri (1811 - 1873). In: Dimensões - Revista de História da UFES. Vitória: NPIH/UFES. 2002. n. 14, p. 127.

${ }^{64}$ Relatório de 13/02/1857, p. 14-15. Biblioteca Digital do APEES. Outro presidente da província, Leão Velloso, em 1859 registra que "pela [estrada] de S. Clara em S. Matheus tem descido algumas boiadas: é uma estrada que se destina a acabar com o isolamento em que está o importante termo de S. Matheus".

${ }^{65}$ Relatório do Presidente da Província do Espírito Santo Evaristo Ladislau e Silva (23/05/1853, p. 34). Biblioteca Digital do APEES.
} 
Janeiro o Mucury, sempre no primeiro de cada mez, e o São Matheus a 12”. ${ }^{66}$ Finaliza suas análises indagando "porque rasão esta província ficou, e continua fora da linha de navegação da Companhia Brasileira de paquetes a vapor", tendo em vista que o porto de Vitória dispõe de acesso fácil e seguro, e também porque tal providência muitos benefícios traria ao progresso e civilização do espírito santo, tirando-o de sua 'imerecida obscuridade' ${ }^{67}$

Dois anos depois, em 1861, o presidente Costa Pereira nos traz novas informações, acerca da navegação a vapor na província, ao se referir à navegação de cabotagem e à fluvial. Em relação à navegação de cabotagem a vapor, registra: "a navegação a vapor cujos benefícios a província reconhece é exercida pela Companhia Espírito Santo que actualmente possue hum excellente navio, o Juparanã, da força de 120 cavallos", o qual faz uma viagem mensalmente, passando pelos portos de Itapemirim, Vitória e São Mateus. Observa que a Companhia Mucury, que enviava (também mensalmente) ao porto de Vitória o vapor São Matheus teve seu contrato 'encampado', mas que certamente o governo contratará com alguma empresa a navegação a que ela (a Companhia Mucury) estava obrigada. ${ }^{68}$ Ressalta ainda que a presidência foi autorizada pela Assembléia Provincial (na lei do orçamento vigente), a subvencionar qualquer empresário que se obrigasse a mandar um vapor todos os meses aos portos de Guarapari, Santa Cruz e Rio Doce - neste sentido tentará entendimentos com a Companhia Espírito Santo ou com o proprietário do vapor São Matheus para que se encarreguem desse serviço.

O contrato para a criação de uma companhia de navegação a vapor no rio São Mateus foi efetuado em 1870, entre o cidadão Olindo Gomes dos Santos Paiva - Barão de Timbuí e o vice-presidente da província Dionísio Álvaro Rozendo, sendo que o percurso da navegação deveria alcançar também o rio Itaúnas, que deságua ao norte da Barra de São Mateus.

Mesmo conseguindo a concessão do privilégio da navegação a vapor do rio São Mateus, o Barão de Timbuí não pôde organizar a Companhia, e, até 1876, a comarca de

\footnotetext{
${ }^{66}$ Relatório do Presidente da Província do Espírito Santo Pedro Leão Velloso (25/05/1859, p. 33). Biblioteca Digital do APEES.

67 Ibidem.

${ }^{68}$ Relatório do Presidente da Província do Espírito Santo José Fernandes da Costa Pereira Júnior (25/05/1861, p. 60). Biblioteca Digital do APEES.
} 
São Mateus ficou privada desse importante melhoramento ${ }^{69}$. Em 1877 o privilégio de concessão foi transferido para José dos Santos Neves, membro de uma importante família da oligarquia mateense ${ }^{70}$, depois de muita polêmica na Assembléia Legislativa Provincial.

Desde 1863 já havia sido autorizado pelo governo provincial a cobrança do imposto de $1 \%$ sobre os produtos exportados pelo município para construção do cais do porto $^{71}$. Também o calçamento da Praça do Comércio, onde as atividades do comércio portuário se desenvolviam, a iluminação a gás e a pavimentação das ladeiras e ruas próximas ao porto, foram realizadas com subvenções do governo provincial, como era de costume na época.

\subsection{A escravidão em São Mateus via oralidade.}

Em seus quatro séculos e meio de colonização, a cidade de São Mateus guardou muitas histórias das relações entre escravos e senhores em sua memória popular, histórias de lutas e covardias, de justiça e bravura, protagonizadas por diversos negros às quais chegaram até nós principalmente via relatos orais. São incontáveis histórias, lendárias ou não, sendo que boa parte delas podem ser em parte atestadas a partir da documentação cartorial então trabalhada.

Por ter sido tão presente e tão intensa, relataremos algumas dessas histórias orais que ainda hoje estão presentes no imaginário mateense, a título de exemplificação, independentemente da re-significação e da reelaboração feita pela memória popular, haja vista a profundidade em que esteve inserida a escravidão nesta região.

Envolto a um universo lendário, o casario e a praça do porto do rio São Mateus, outrora Cricaré, serve de pano de fundo para as mais curiosas histórias de aventura e rebeldia, deflagradas por negros e abolicionistas que não se enquadraram no sistema de

\footnotetext{
${ }^{69}$ Debate sobre a Navegação do Rio São Mateus. "Deputado fala contra a Concessão de Privilégio dado a José dos Santos Neves". In. BICHARA, Terezinha Tristão. História do Poder Legislativo do Espírito Santo/ 1835-1889. vol.1. Vitória, 1984. p. 276.

${ }^{70}$ José dos Santos Neves era irmão do promotor João dos Santos Neves e do médico Graciano Santos Neves, sendo também pai do reconhecido médico Dr. Jones que e avô do governador Jones dos Santos Neves (1945). José dos Santos Neves foi também tio do governador Graciano Santos Neves (1895-1897), filho de seu irmão Graciano (médico).

${ }^{71} \mathrm{O}$ imposto foi criado sob a administração do presidente José Joaquim do Carmo (1863-1865), e a cobrança foi prorrogada no governo do presidente Manoel José da Menezes Prado (1875-1877).
} 
dominação vigente. Entre estes destacam-se Benedito Meia-Légua, Negro Rugério, Silvestre Nagô, Constância de Angola, Viriato Cancão-de-Fogo, Clara Maria dos Rosário, entre outros, relativos ao período estudado (segunda metade do século XIX), alguns dos quais tivemos conhecimento através da documentação cartorial trabalhada, tais como, por exemplo, o documento de doação do escravo Benedito Meia-Légua. Se considerarmos só as fontes orais, poderíamos retroceder ainda mais no tempo, às histórias que remontam à princesa de Cabinda, Zacimba Gaba, revolucionária das primeiras décadas do século XVIII, chegada escrava em São Mateus por volta de 1690, segundo a lenda.

De Benedito Meia-Légua, tivemos acesso à cópia da escritura de sua doação que diz o seguinte:

Crioulo preso na cadeia dessa cidade, sentenciado pelo júri à prisão das galés perpétua. Sendo doador Manuel Rodrigues de Oliveira e donatário o advogado João Pereira da Silva Sarmento, cuja transferência foi registrada no Livro ${ }^{\circ} .1$, Fls. 49, a 11 de junho de $1864 .{ }^{72}$

Segundo Maciel de Aguiar, conta-se que esse advogado que recebeu a doação de Meia-Légua, era do Rio de Janeiro, abolicionista e ligado a José do Patrocínio. Mas Benedito teria se evadido da prisão meses depois e passou com seu bando a saquear fazendas e libertar os escravos que viviam nas senzalas.

Para as tentativas de captura de Meia-Légua, existe o memorável relatório do Ministro da Justiça à época, Francisco Maria Sodré Pereira, citando as ações atribuídas a Benedito Meia-Légua, justificando assim a necessidade de sua captura pelas Forças do Governo. $^{73}$

\footnotetext{
${ }^{72}$ Cartório de $1^{\circ}$. Ofício de São Mateus. Livro do Notariado. Livro 1, fl. 49, de 11 de junho de 1864. Escritura de doação do escravo Benedito.

${ }^{73}$ Diz o documento:"Termo de São Mateus -- Ao Chefe de Polícia comunicou o Delegado que um grupo de 20 a 30 escravos, fugidos de diversas fazendas, todos armados e capitaneados por Benedito, criminoso evadido da cadeia, vivem nas matas da fazenda de João Rodrigues de Oliveira Guedes, atacando na estrada os viandantes e roubando as fazendas, sem ser possível capturá-los por falta de Força. Acrescentava o informante que os escravos do município pretendiam, no dia de Sant'Ana, fazer uma inssurreição, a fim de ficarem todos livres. O Presidente fez logo seguir para São Mateus 24 praças de linha, um inferior e um corneta, sob o mando de um oficial de confiança, a fim de bater os quilombolas e restabelecer a ordem e segurança na localidade. Com a notícia de continuar os calhambolas a invadir as fazendas e agredir os seus habitantes, sendo pelo dito Benedito arrancada uma menor do poder de seus pais e barbaramente estrupada, determinou o Presidente fazer seguir o Chefe de Polícia para São Mateus. A Força prendeu sete quilombolas, criminoso, co-réu de Benedito, e oito acoutadores e aliciadores de escravos, sem que houvesse incidente algum a lamentar-se. O alferes comandante da Força, depois de cercado o quilombo, penetrou nele sozinho e nessa ocasião ouviu-se dois tiros. Bendito errou o alvo e fêzse em fuga, perseguido pelo mesmo alferes, que não conseguiu capturá-lo. O quilombo ficou destruído e
} 
Sodré Pereira, determinou ao governo da Província do Espírito Santo sua captura em 5 de maio de 1885, pelo 'Termo de São Mateus', documento que narra notícias do Chefe de Polícia da província de que "um grupo de 20 a 30 escravos, fugidos de diversas fazendas, todos armados e capitaneados por Benedito, viviam nas matas atacando na estrada os viandantes e roubando as fazendas ". ${ }^{74}$

Nos relatos orais, no bom tempo de suas andanças, Benedito carregava uma imagem de São Benedito junto a seu corpo, atuando com grande devoção na Irmandade de São Benedito dos Homens Pretos. Organizava a festa popular de São Benedito e outros folguedos, como congados ou Baile de Congos também conhecido regionalmente por Ticumbi. É considerado um dos maiores líderes negros da região, com a sua rebeldia ao utilizar a devoção ao santo negro para fins de ações de resistência à escravidão, dominando a região conhecida por Sapê do Norte por mais de quarenta anos. Teria sido assassinado (queimado vivo no interior de uma árvore) pelas Forças do Governo em 1885, já octogenário, nas matas onde vivia. Segundo a lenda, a imagem de São Benedito retida junto ao corpo de Meia-Légua não foi destruída pelo fogo no interior da árvore, o que gerou a popular festa de traslação dessa imagem pelo rio São Mateus todo dia 31 de dezembro.

Outro escravo que se tornou uma espécie de figura lendária foi o já citado Negro Rugério, que, juntamente com Sivestre Nagô e outros trinta negros aproximadamente, de origem angolana, se aquilombaram nas terras de Dona Rita Cunha, esposa do comendador Antonio Rodrigues da Cunha e mãe do Barão de Aimorés, em meados do século XIX, segundo relatos orais recolhidos pelo escritor Maciel de Aguiar, em fins da década de 1960 e início de 70. Ao tomar conhecimento de que um de seus escravos de maior confiança havia se aquilombado em sua própria fazenda, e, já conhecendo a inteligência daquele negro, Dona Rita selou um acordo com Negro Rugério, que era mestre de farinha e importante produtor deste produto:

dona Rita comprometia-se a não chamar a Força ou os capitães-do- mato para a captura dos negros fugidos, permitindo que eles se instalassem às margens do rio São Domingos, (...) e ainda daria proteção política caso fosse de interesse da Força do Governo da Província invadir o quilombo para prender os seus habitantes. Ela compraria a farinha de mandioca pela metade do preço e revenderia para os atacadistas (...) Negro Rugério se

os calhambolas que não foram presos refugiaram-se nas matas...”. Rio de Janeiro, 5 de maio de 1885. Francisco Maria Sodré Pereira - Ministro da Justiça.

74 AGUIAR, Maciel de. Os últimos Zumbis: a saga dos negros no vale do Cricaré durante a escravidão. Porto Seguro, Brasil-Cultura, 2001. p. 320. 
comprometeu a produzir a farinha que dona Rita necessitasse, trazendo a farinha em sacas, nas canoas, até o Porto de São Mateus e dona Rita só teria o trabalho de embarcar a mercadoria nos navios. ${ }^{75}$

Segundo o escritor, a farinha de mandioca era um dos principais produtos que vinham do interior do país, para a mesa da 'aristocracia', e a farinha de São Mateus, notadamente produzida por Negro Rugério e comercializada por dona Rita Cunha, era a que tinha melhor cotação nos mercados consumidores das grandes cidades. Durante o Primeiro e Segundo Reinados, São Mateus se notabilizou como exportador de farinha, sendo que a partir de meados do século, esse produto passa a ter uma cotação própria na Corte "notadamente com a participação do Quilombo do Negro Rugério e com a cumplicidade de dona Rita Cunha que garantia o trabalho dos negros em suas terras em troca da exclusividade da compra da produção". ${ }^{76}$

Nesse contexto, Negro Rugério estabeleceu-se como importante farinheiro da região, 'tornando-se Rei da Farinha"77. Seu quilombo, o Quilombo de Santana, mesmo sob a proteção de Dona Rita Cunha, começou a incomodar os proprietários rurais locais, que pressionavam sob a alegação de que nele 'viviam gentes condenadas por vários crimes, saqueadores de fazendas e escravos fugidos', muitos dos quais há anos procurados por capitães-do-mato e pelas guerrilhas dos governos da província.

Em ambos os relatos que estamos transcrevendo, Rugério sentindo-se seguro com o acordo selado com Dona Rita Cunha, que enquanto viveu manteve seu compromisso com o Negro, passou a cobrar dos aquilombados uma produção cada vez maior, agindo igual aos senhores no tratamento com os negros:

de chicote em punho, Negro Rugério andava pelas farinheiras açoitando os negros e obrigando-os a trabalhar, como se fosse um feitor, até que os revolucionários passaram a pressioná-lo pela postura autoritária e por aquelas atitudes, que tanto combatiam. Ele não gostava de festa, não perdia tempo vendo as brincadeiras, seu negócio era produzir farinha cada vez mais, com a mesma filosofia dos senhores de escravos, e já não pensava em sua raça, visto que já não se considerava mais um escravo, mas um senhor ${ }^{78}$.

\footnotetext{
75 AGUIAR, Maciel de. Os últimos Zumbis: a saga dos negros do vale do Cricaré durante a escravidão. Porto Seguro: Brasil Cultura, 2001, p.101. Baseado no relato de Manduca Evêncio (1965 e 1971), apelido de Manoel Antonio de Oliveira. Morador da cidade de São Mateus, Evêncio era jornalista e historiador. Apontamentos coletados em Conceição da Barra.

${ }^{76}$ Ibidem, p. 103.

${ }^{77}$ Ibidem, p. 105. Afirmação de Hermógenes Lima Fonseca. Entrevista realizada em 18 /12/1978, em Conceição da Barra. Hermógenes Lima é folclorista.

${ }^{78}$ Ibidem, p. 106. Relato de Manduca Evêncio.
} 
Esses 'revolucionários' citados são os escravos que não aceitavam o tratamento dado por Rugério, e que provocavam pequenas rebeliões no Quilombo de Santana ${ }^{79}$, as quais foram todas sufocadas por ele. Outros negros libertários chegaram a ameaçar invadir Santana para libertar os negros que viviam açoitados, tais como o já citado Benedito Meia-Légua, Viriato Cancão-de-Fogo, Constança de Angola e Clara Maria do Rosário.

Porém com a morte de Dona Rita em fins da década de 1870, as coisas mudaram e o Negro Rugério, ameaçado pelos proprietários rurais, se vê obrigado a mudar de postura em relação aos negros rebelados.

A morte de Dona Rita simboliza o início da decadência do Quilombo, onde cada negro "passou a cuidar de seu próprio interesse, o que era coletivo passou a ser individual, relaxando a segurança e abandonando todos os objetivos de uma agricultura participativa". 80

Nesse contexto, as Forças do Governo apoiadas pelos proprietários rurais promove um cerco ao Quilombo no dia 26 de julho de 1884, no dia de Nossa Senhora de Sant'Ana, pondo fim a ele, devido à notícia da ameaça de uma insurreição, em que todos os negros seriam libertados.

Durante os 'anos de ouro’ do Quilombo de Santana, Negro Rugério, em função do compromisso com Dona Rita, conseguiu a alforria de um de seus escravos de confiança, conhecido por Silvestre Nagô, homem 'astucioso, sarcástico e festeiro' ${ }^{81}$, o qual viria a ter importante papel no contexto da produção da farinha de mandioca na segunda metade do século XIX. Nagô seria

\footnotetext{
a ligação com dona Rita, viveria pelo largo da praça do Porto, de fraque, bengala e cartola, vistoriando a chegada da carga, recebendo dinheiro da venda da farinha e sempre tendo que mostrar-se vitorioso, garboso e insolente, como prova de que os negros não eram preguiçosos, ignorantes
}

\footnotetext{
${ }^{79}$ Sabemos que a região litorânea brasileira foi palco de muitas rebeliões escravas, a exemplo da fazenda produtora de açúcar conhecida por Engenho de Santana, situada ao norte de São Mateus, em Ilhéus (sul da Bahia), onde os escravos se rebelaram ao longo de diversas décadas, sendo a mais destacada a revolta de 1789. Nesta data os escravos tomaram a direção da fazenda, matando o capataz, e dominando a produção do açúcar por dois anos. Cf. SCHWARTZ, Stuart. Segredos Internos: Engenhos e escravos na sociedade colonial. São Paulo: Companhia das Letras, 1988; MARCIS, Teresinha. Viagem ao Engenho de Santana. Ilhéus: Editus, 2000; REIS, João José e SILVA, Eduardo. Negociação e conflito: a resistência negra no Brasil escravista. São Paulo: Companhia das Letras, 1989.

${ }^{80}$ Ibidem, p. 108. Afirmação de Hermógenes Lima Fonseca.

81 AGUIAR, Maciel de. Os últimos Zumbis: a saga dos negros do vale do Cricaré durante a escravidão. Porto Seguro: Brasil Cultura, 2001, p.169.
} 
passivos e desprovidos de inteligência ${ }^{82}$.

Segundo Maciel de Aguiar, este negro infernizou a vida da 'aristocracia' rural mateense com sua

pose de lorde inglês, sua roupa mandada vir do Rio de Janeiro, que nem
os ricos usavam, dado o seu alto valor, mas andava de pés descalços, como
a dizer que estava fazendo uma fina ironia aos brancos e, quando perguntado,
falava sempre que só calçaria os sapatos quando os negros pudessem
calçar.

Além da função de recebedor e despachador da farinha vinda do Quilombo para o porto de São Mateus, Silvestre Nagô teria desempenhado também uma outra atividade que resultaria no surgimento de tradições culturais de grande importância regional, como o Baile de Congos, conhecido também como Ticumbi, a Marujada e o Reis-deBoi. Era 'festeiro e lustroso' ${ }^{94}$, e na organização de seus folguedos, os negros eram vestidos com roupas 'decentes e enfeitadas'.

Segundo Aguiar, Nagô introduziu estas ‘brincadeiras' nas festas de São Benedito e no Natal - definidas pelos estudiosos como 'ciclo natalino', que vai de 25 de dezembro a 3 de fevereiro, dia de São Brás - , atravessando duas outras datas importantes, 6 de janeiro (Santos Reis) e 20 de janeiro (São Sebastião). As 'brincadeiras' introduzidas por Nagô passaram a mobilizar a população, que vinha às ruas para festejar estes acontecimentos. ${ }^{85}$

Ao contrário de Rugério, que vivia para trabalhar na produção de farinha no Quilombo, Sivestre Nagô se torna um símbolo de prosperidade e uma espécie de amálgama entre o misticismo dos negros e a Igreja Católica, na cidade de São Mateus, se tornando um mito regional.

Em sua especialidade de comerciante de farinha, comerciava os derivados desse produto na calada da noite, vendendo inclusive a farinha de Dona Rita para outros compradores, numa espécie de contrabando, passando 'de canoa para canoa nas barrancas do Cricaré', sempre fazendo chegar os produtos ao armazém do porto:

\footnotetext{
${ }^{82}$ Ibidem, p. 169. Relato de Manoel Antonio de Oliveira (Manduca Evêncio).

${ }^{83}$ Ibidem, p. 169. Relato de Manoel Antonio de Oliveira (Manduca Evêncio)

${ }^{84}$ AGUIAR, Maciel de. Os últimos Zumbis: a saga dos negros do vale do Cricaré durante a escravidão. Porto Seguro: Brasil Cultura, 2001. Pág. 171. Relato de Manoel Antonio de Oliveira (Manduca Evêncio)

${ }^{85}$ Ibidem, p. 171.
} 


\begin{abstract}
Silvestre Nagô estabelecia uma relação clandestina que prosperava a cada dia, negociando a farinha com dona Rita e os beijus de fáti de coco, de amendoim, de roda, além do polvilho, da goma, da farinha de coco, da pamonha e, sobretudo da tapioca, que a aristocracia rural cada vez disfarçava na hora de comprar (...) Na prática, era proibido aos quilombolas vender ou trocar seus produtos sem que deixassem uma parcela de lucro aos comerciantes locais. Se assim fosse, ninguém reclamava, e Silvestre Nagô podia freqüentar os estabelecimentos falando com os proprietários no mesmo tom de voz, e sem constrangimentos das partes ${ }^{86}$.
\end{abstract}

Nos estudos relativos aos quilombos, a questão da aceitação dos seus produtos nos mercados das cidades do interior e também das capitais, é um assunto ainda não muito explorado. Embora esse fenômeno comercial ocorra em várias partes do Brasil, não podemos afirmar muito acerca da qualidade desses produtos e de sua aceitação popular. Quando não eram destinados à venda, eram trocados por sal, pólvora, armas de fogo e tecidos preferencialmente. Embora houvesse medidas de repressão por parte dos governos das províncias, contra esse comércio, sabe-se que ele era praticado. Segundo Almada, no sul da Província do Espírito Santo, na região de Itapemirim, "os quilombolas, através da ajuda de outros escravos, mantinham relações com as comunidades vizinhas com as quais trocavam alguns produtos de suas roças por mercadorias de que necessitavam, tais como sal, aguardente e farinha. Além disso, sobreviviam roubando gado e objetos como roupas e armas [...]". ${ }^{87}$

Em São Mateus,

as canoas ficavam em fila, na enchente do rio Cricaré, esperando para descarregar a produção que vinha do Quilombo do Negro Rugério, a que os compradores não tinham acesso e somente dona Rita era a beneficiária. Compromisso de palavra, mas compromisso de verdade, e como tal revendia para os demais comerciantes a preços bem em conta, deixando os outros produtores praticamente sem mercado e com muita indignação. Era uma sociedade em que todos saíam ganhando, mas dona Rita e Negro Rugério, a bem da verdade, a maior parte, e os demais negros ganhando uma vida de respeito e dignidade, podendo produzir, dançar, festejar os santos da devoção e, sobretudo, fazer 'Cabula' 88 .

\footnotetext{
${ }^{86}$ Ibidem, p. 174.

87 ALMADA, Vilma Paraíso Ferreira de. Escravismo e Transição: o Espírito Santo (1850-1888). R.J.: Edições Graal, 1984, p. 163.

${ }^{88}$ AGUIAR, Maciel de. Os últimos Zumbis: a saga dos negros do vale do Cricaré durante a escravidão. Porto Seguro: Brasil Cultura, 2001, p. 173.
} 
Segundo Aguiar, no Rio de Janeiro, “os jornais davam uma cotação especial para os produtos produzidos em São Mateus, em especial a farinha e os bijus, e lembravam que eles eram produzidos num quilombo nas terras de uma rica senhora de escravos", levantando-se a suspeita de que "havia um franco comércio dela com os negros aquilombados, entre estes um negro que andava pelas ruas de São Mateus, usando fraque, bengala e cartola e pés descalços". Devido a esse fato, "muitos mercadores chegavam em São Mateus e iam logo perguntando pelo negro de fraque, cartola, bengala e pés descalços com o objetivo de negociar". ${ }^{89}$

Sendo assim, Nagô teria se transformado em comerciante respeitado e procurado, instaurando uma concorrência que incomodava os negociantes locais.

Nesta conjuntura de fatos, a fiscalização teria sido acionada pelos concorrentes de Nagô, que foi preso por comerciar sem autorização, numa falsa negociação comercial armada pelos fiscais da receita:

\begin{abstract}
chegaram os policiais e o levaram para a Cadeia Velha, mas antes era preciso arrancar seu fraque na praça, levá-lo quase despido para a prisão, desmoralizando-o, para que nunca mais se atrevesse (...) Nagô foi levado ao centro da praça, no Porto, como se fosse um criminoso e, numa espécie de julgamento sem defesa foi condenado a duzentos açoites $(. . .)^{90}$
\end{abstract}

A partir de então ninguém mais teria se atrevido a negociar farinha com desconhecidos, exatamente no momento em que guerrilhas eram formadas para combater o Quilombo de Santana, já após a morte de Dona Rita Cunha.

Outra história de negros que viveram em São Mateus no decorrer do século XIX, que ficou na memória popular, foi a de Constança de Angola, escrava do coronel Matheus Gomes da Cunha, filho de Dona Rita Cunha e irmão de Aimorés. Trata-se de um caso de violência contra a criança, visto que o filho de Constança, criança de colo ainda, foi jogado na fornalha da casa de farinha da fazenda Boa Esperança, pela primeira esposa do coronel, Dona Romana. Com a morte da criança, Constança começou a ameaçar a patroa de morte, que a mandou para o tronco, aprisionando-a na senzala. Com este fato houve uma tentativa de rebelião na fazenda Boa Esperança. Afastada desta fazenda pela família Cunha, a esposa do coronel Mateus foi viver em

\footnotetext{
${ }^{89}$ Ibidem, p. 177.

${ }^{90}$ Ibidem, p. 178. Relato de Balduíno Antônio dos Santos. Balduíno (95 anos de idade) é 'cabuleiro' e cantador, além de mestre do Alardo de São Brás. Entrevista realizada em 18 de junho de 1968, em São Mateus.
} 
São Mateus. Ajudada pelo grupo de negros liderados por Viriato Cancão-de-Fogo, a escrava Constança teria conseguido libertar-se indo viver nos matos, passando a comandar lutas contra os capitães-do-mato e as forças do governo e apoiando o grupo de Benedito Meia-Légua.

Com o grupo de Viriato Cancão-de-Fogo, Constança saquearia várias fazendas, libertando escravos que padeciam nos instrumentos de tortura das senzalas das fazendas de São Mateus.

Outra jovem negra que se notabilizou no cenário opressor da escravidão em São Mateus no século XIX foi Clara dos Anjos, ou Clara Maria do Rosário dos Pretos, personagem ativa no processo de libertação dos negros. Mucama de uma família rica teve a oportunidade de aprender a ler e a escrever, passando a desfrutar de grande prestígio junto aos abolicionistas, devido às suas orientações e à sua atuação muito bem desempenhada, integrando-se, ainda na juventude, à ação desses intelectuais.

Clara passou a interligá-los pelos mesmos anseios de liberdade, levando informações aos escravos fugidos e orientando os que lutavam na cidade, colocando em prática os planos da destruição das lavouras pelo fogo ateado na calada da noite, como forma de intimidação'.91

Junto com os abolicionistas, teria passado a organizar a Irmandade de São Benedito dos Homens Pretos, confraria religiosa mais sensível à luta dos negros. Clara exerceria aí importante papel, ela

\begin{abstract}
que sabia a leitura e as quatro operações e, principalmente, falar pros homens de letra. Andava pelos matos, na calada da noite, lendo as notícias que saíam nos jornais, reunindo os negros que ouviam com muita atenção suas palavras, para no outro dia se encontrar com os sinhozinhos que lutavam na cidade. ${ }^{92}$
\end{abstract}

Na Província do Espírito Santo, desde 1869 já havia organizações libertárias, pois boa parte da elite intelectual capixaba era entusiasmada com o ideal abolicionista.

\footnotetext{
91 AGUIAR, Maciel de. Os últimos Zumbis: a saga dos negros no vale do Cricaré durante a escravidão. Porto Seguro, Brasil-Cultura, 2001, p. 134. O senhor de Clara- um fazendeiro da Bahia, que havia decidido viver em São Mateus 'pela facilidade de comprar escravo e de fazer justiça com as próprias mãos’ - chamava-se Luís José dos Santos Guimarães (proprietário de uma das firmas comercializadoras de escravos as quais retornaremos no capítulo 3) e havia, em 5 de fevereiro de 1882, declarado ao Fundo de Emancipação, presidido por Manoel Lopes de Azevedo, o valor de 960\$000 (novecentos e sessenta mil-réis) 'para efeito de indenização por sua escrava de nome Clara, na tentativa de se livrar da presença de quem já incomodava a classe dominante local'.

92 Ibidem, p. 137. Depoimento de Balduíno Antônio dos Santos.
} 
Clara teve uma filha com um abolicionista mateense, José Antonio de Souza Lé, fixando assim raízes na região. A filha de Clara, Lavínia da Boa Morte, se casou com Cercinílio Aguiar, se tornando posteriormente avós de Maciel de Aguiar. Segundo Maciel, durante sua infância ouviu inúmeros relatos sobre negros contados pelo avô, que ficaram em sua memória, os quais o motivaram a recolher, posteriormente, os depoimentos orais remanescentes da escravidão na região. ${ }^{93}$

Além dos nomes de negros que ficaram na memória popular em São Mateus, tidos como líderes revolucionários, tanto homens quanto mulheres, não podemos deixar de destacar também um tipo de ritual dos negros que havia nesta região, o qual teria arrebanhado milhares de adeptos, inclusive brancos, durante a segunda metade do século XIX, uma espécie de sincretismo religioso que provocou muita polêmica por parte da Igreja Católica, que é a prática da Cabula. O ritual da Cabula,${ }^{94}$ conforme a versão de Aguiar, era praticado nas matas dos sertões de São Mateus e da Barra de São Mateus, principalmente nas matas do Jacarandá. Esta prática cerimonial, oriunda de ancestrais africanos, segunda a lenda, teria sido trazida por Viriato Cancão-de-Fogo para o meio popular de São Mateus:

Viriato era africano de nascença e veio para o Brasil num navio apinhado de escravos, ainda menino, por isso não se lembrava de seus pais, dizia sempre que era filho da África, parido da barriga da noite, e só andava na escuridão, nunca via a luz do dia era uma figura mítica, lendária, que servia de socorro para todos os necessitados. (...) Trazia no corpo cicatrizes feitas

\footnotetext{
${ }^{93}$ Segundo Aguiar, que era então bisneto de Clara dos Anjos, seu avô, Cercinilio Aguiar, fora criado no Sapé do Norte, sertão de São Mateus, região que durante o Segundo Reinado viveu o apogeu econômico em função do ciclo da farinha de mandioca. Esta região teria gerado três quilombos e vários líderes negros que enfrentaram os capitães-do-mato deixando provas de que os negros não aceitaram pacificamente o cativeiro, o que justifica a existência de diversos instrumentos de castigos físicos encontrados na região, tais como gargalheiras, algemas, grilhetas, troncos, grilhão, giramundo, golilha, etc.

${ }^{94}$ Cf. SLENES, Robert. A Árvore Nsanda Transplantada: Cultos Kongo de Aflição e Identidade escrava no Sudeste Brasileiro (séc. XIX). In. LIBBY, D.C. e FURTADO, J. F. (org.). Trabalho livre, trabalho escravo: Brasil e Europa, séculos XVII e XIX. São Paulo: Anablume, 2006. Segundo Slenes, a cabula "era uma religião una, com variações". Entre as manifestações identificadas por este autor na África Central e no Sudeste brasileiro estão "as reuniões em clareiras na floresta, perto de riachos, onde estariam presentes os espíritos da terra; a adoração aos primeiros habitantes da terra em que estão e a seus sacerdotes, o que, no caso brasileiro, leva os negros a procurarem os sacerdotes indígenas, promovendo o sincretismo; e a utilização de uma língua secreta, que inseria prefixos 'ca' na frente de todas as palavras, como 'Cabula' onde 'bula' significa 'quebrar' e estaria relacionada ao transe religioso. [...] $\mathrm{O}$ ponto culminante da cabula é quando a pessoa recebe um nome específico, que fica para o resto de sua vida e representa o seu guia espiritual.[...] De acordo com pesquisadores, as manifestações religiosas caminhavam junto com planos de rebelião, como as conspirações que ocorreram em Vassouras em 1848 e em São Roque, no Espírito Santo, em 1854."
} 
pelo corte do 'sacrifício do Camucito' e tinha a pele povoada por marcas dos ferros dos troncos quando vivia nas fazendas. Foi quem trouxe a Cabula para o meio do povo, no passado ela só podia ser vista por gente escolhida, e não era qualquer um que podia assistir, tinha que ter santo. ${ }^{95}$

Diz a lenda que Viriato mandava o Tatá, o espírito destemido, para acudir 'o necessitado', havendo vários desses espíritos na Cabula. Este africano virou um mito nas histórias relacionadas a essa seita, principalmente a da 'Mesa de Santa Maria', 'no grotão da mata virgem, antes do bispo proibir e mandar muita gente prá cadeia' ${ }^{96}$

Os praticantes da Cabula ou cabulistas se reuniam na mata fechada, na noite alta, tendo a sua reunião o nome de Mesa. Em São Mateus havia 'duas Mesas Capitulares: a de Santa Bárbara e a de Santa Maria' e, acredita o escritor Maciel de Aguiar ter existido ainda uma terceira Mesa, 'a de nome São Cosme e São Damião - mais misteriosa e mais central'. O chefe da Mesa tem o nome de enbanda, secundado em seus trabalhos pelo cambone. As reuniões eram secretas, ora em determinada casa, mas geralmente nas matas, sempre à noite, todos de branco e descalços, onde os comuns, os camanás, se dirigiam ao Camucito, local escolhido para a realização dos rituais. Diz a lenda que os baculos, que são os guerreiros da Cabula, apareciam nas horas críticas em auxílio a Viriato Cancão-de-Fogo, que encarnava também um destes ${ }^{97}$.

Mesmo envolto a todo um mundo místico, Viriato teria sido acusado por ajudar na fuga da escrava Constança de Angola e por se unir a outros negros na resistência do

\footnotetext{
${ }^{95}$ Ibidem, p. 27. Relato de José Antonio Jorge, conhecido como Zé de Ana (85 anos), importante tirador de Baile de Congos, folguedo conhecido como Ticumbi, além de conhecedor de segredos da seita. Entrevista realizada em 20 de outubro de 1968.

${ }^{96}$ Ibidem, p. 29. D. João Batista Corrêa Nery, bispo do Espírito Santo entre 1863 e1920, com uma postura extremamente reacionária, perseguiu os praticantes da Cabula, dando fím à sua prática, após violenta repressão. Os registros deixados pelo bispo à época, em suas andanças pela região, publicados em sua Carta Pastoral (1901), contém informações detalhadas dessa prática, se tornando um documento importante cujas descrições impressionaram estudiosos da época como Nina Rodrigues e Artur Ramos. Segundo o bispo a Cabula nada mais é do que 'vestígios de uma religião atrasada e africana ... .resultando de tudo isso perigosa amálgama, que só serve para ofender a Deus e perverter as almas’ (Carta Pastoral, 1901).

${ }^{97}$ In: AGUIAR, Maciel de. Os últimos Zumbis: a saga dos negros do vale do Cricaré durante a escravidão. Porto Seguro: Brasil Cultura, 2001, p. 33. Uma outra figura lendária, Preto Bongo, um ex-escravo originário da Guiné, segundo Maciel de Aguiar, 'que se orgulhava de nunca ter sido batizado', confundese com as lendas de curas e magia atribuídas a ele. Segundo a lenda, era temido por conversar com os baculos, espécie de divindade encontrada nos terreiros da Cabula, que adivinhava pensamentos, além de fazer desaparecer e aparecer animais diante dos olhos de todos. Era capaz de, sozinho, 'botar para correr a Força do Governo e os capitães-do-mato que viviam perseguindo os escravos fugidos das fazendas'. In: AGUIAR, Maciel de. Os últimos Zumbis: a saga dos negros do vale do Cricaré durante a escravidão. Porto Seguro: Brasil Cultura, 2001, p. 33.
} 
Quilombo de Santana, em 1884, quando morreu Negro Rugério, além da participação em várias lutas para a libertação de negros cativos.

Enfim, poderíamos citar ainda vários outros nomes de líderes negros que, na memória popular mateense, desafiaram as normas sociais vigentes e enfrentaram as forças policiais de repressão à escravidão. Porém, nossa proposta de trabalho vai além de uma reflexão baseada nas histórias orais, sendo esta breve incursão apenas uma tentativa de elucidar a dimensão do campo trabalhado. 


\section{CAPÍTULO 2}

A ESCRAVIDÃO NAS DISCUSSÕES OFICIAIS E NA LEGISLAÇÃO DO ESPÍRITO SANTO NA SEGUNDA METADE DO OITOCENTOS 
Os recortes temáticos e temporais adotados nesta parte do estudo têm por referência a consulta/análise da vasta documentação produzida no âmbito das instâncias governamentais da província capixaba no decorrer do Oitocentos, cuja maior parte deste acervo se encontra sob a guarda do Arquivo Público Estadual do Espírito Santo/APEES, sendo que certas séries documentais estão digitalizadas e disponibilizadas à pesquisa.

O rico repertório dessas fontes oficiais é constituído, sobretudo, pelos Relatórios Presidenciais - elaborados e publicados entre 1835 e 1888 -, pelo Ementário da Legislação Provincial - discutida e aprovada nas sessões realizadas pela Assembléia Legislativa capixaba - e na qual se incluem ainda os conteúdos expressos nas Posturas Municipais da cidade de São Mateus e da Vila da Barra de São Mateus, cujas normas estabelecidas na edilidade passavam também pela aprovação da Assembléia Provincial.

Trata-se de documentos importantes para os estudos referentes à história do Espírito Santo no período imperial, pois trazem ricas informações acerca da situação geral da província, fornecendo importantes dados sobre diversos temas e questões relativas ao contexto sócio-econômico e político capixaba, dentre estes, os temas ligados à escravidão no Espírito Santo e em São Mateus.

A consulta à legislação provincial foi facilitada pela existência de um Catálogo elaborado pelo Arquivo Público do Estado do Espírito Santo (APEES), no qual se encontra a relação da legislação aprovada no período estudado, com o título e a ementa dos itens referentes aos decretos, leis, regulamentos, resoluções, atos e instruções, abarcando vários temas e assuntos. No caso específico deste estudo, procedemos à seleção e análise dos itens relativos aos escravos e à escravidão na província capixaba.

Quanto à legislação municipal, reunida sob o nome de Posturas Municipais da Vila da Barra de São Mateus e da cidade de São Mateus, estas foram sucintamente analisadas, haja vista que as mesmas conformam um quadro parcial da sociabilidade da população, incluindo aí os escravos, seus comportamentos e costumes, a estrutura material onde se assentava a sociedade local da época, dentre outros aspectos, os quais serão explorados no desenvolvimento do capítulo.

Procuraremos colocar em evidência o conjunto das medidas legislativas e das providências adotadas pelo governo provincial com vistas a manter sob controle as situações e os movimentos que conformaram a resistência escrava no Espírito Santo, principalmente no que se refere à repressão aos escravos fugitivos, à proliferação dos 
quilombos e também às ameaças ou ocorrências de insurreições/revoltas escravas em distintos momentos no território espírito-santense.

Nesta perspectiva, grande parte das informações reunidas neste capítulo tem o intuito de demonstrar que as autoridades da província capixaba encontraram sérios obstáculos no encaminhamento prático dessas medidas, a exemplo das diversas situações respaldadas pela legislação criada e aprovada no período, na qual se destaca a formação de guerrilhas para captura de escravos fugidos e destruição dos quilombos, e onde sobressai a precariedade do aparato policial da província que, por sua vez, gerava grandes dificuldades no momento de composição das guerrilhas e na garantia dos recursos necessários à manutenção das mesmas, cujas lacunas eram apontadas como principais causas do freqüente fracasso governamental na resolução de tais problemas.

Além destas questões, também focaremos outros aspectos relativos ao escravismo na província capixaba, tais como os fatos envolvendo suicídios de escravos, ocorrências policiais, criminalidade, estruturas judiciais e o trato dos poderes local e provincial no tocante à escravidão, procurando, na medida do possível, associar tais situações ao contexto mais amplo do sistema escravista, principalmente nos momentos em que as determinações legais em relação à escravidão e oriundas do governo central deveriam ser acatadas nas províncias, a exemplo das principais medidas decretadas no período imperial com vistas à abolição gradual da escravatura, dentre as quais dedicaremos especial atenção à criação do Fundo de Emancipação de Escravos no início da década de 1870, cujas prerrogativas foram estabelecidas na Lei do Ventre Livre para serem aplicadas em todo o Império.

\subsection{A escravidão nos Relatórios dos Presidentes da Província.}

Revoltas, quilombos, fugas de escravos e a formação de guerrilhas para combatê-los.

No conjunto das fontes oficiais já referidas, constatamos uma maior incidência de questões relativas às formas de resistência escrava ao cativeiro, cujas manifestações e ocorrências foram registradas em distintos momentos e abarcaram diferentes regiões da província. Portanto, o ponto de partida de nossas análises recairá sobre esta temática, com vistas a reunir e caracterizar os fatos mais significativos que marcaram as formas de resistência escrava no Espírito Santo, as medidas e providências adotadas pelo 
governo provincial para a resolução desses conflitos, e os elementos subjacentes aos discursos oficiais acerca da manutenção e do equilíbrio do sistema escravista regional.

Ressaltamos inicialmente a relevância da abordagem deste tema, considerando que a questão atual envolvendo os procedimentos acerca do reconhecimento e titulação das comunidades remanescentes de quilombos, colocada formalmente pela Constituição Brasileira de 1988, reacendeu a discussão em torno da temática nos meios acadêmicos, sobretudo no campo das ciências sociais, onde a antropologia e a história ocupam papéis de destaque na abordagem da referida matéria.

Em se tratando da história, nota-se que nos últimos tempos, o conjunto da produção historiográfica registrou um crescimento contínuo dos estudos relativos aos diversos aspectos que conformaram a instituição escravista no Brasil, nos quais se destaca o tema da resistência escrava e os processos de formação dos quilombos. ${ }^{98}$

Assim, ao atentarmos para as práticas de fugas dos escravos e para a ocorrência dos quilombos ao longo do período de vigência do sistema escravista no Brasil, constatamos que tais fenômenos foram recorrentes desde o período colonial, cuja temática é abordada por Guimarães em seu estudo relativo aos quilombos em Minas Gerais no século XVIII ${ }^{99}$, no qual observa que "onde quer que o escravismo tenha sido implantado constatamos o surgimento de comunidades formadas por escravos fugidos de seus senhores: os quilombos". Segundo ele, os quilombos constituíram uma das mais completas e complexas formas de reação escrava nas Minas Gerais setecentista, quando foi expressiva a participação destes na dinâmica social, haja vista que no período de 1710 a 1798, registrou-se a descoberta e destruição de, pelo menos, 160 quilombos em Minas, cujos dados reforçam ainda mais a recusa das propaladas teses da "escravidão suave", da relação harmoniosa entre senhores e escravos, e também da passividade e aceitação, por parte dos escravos, da sua condição cativa.

Mesmo que as pesquisas de Guimarães se refiram ao século XVIII, muitas das questões e análises por ele destacadas apresentam aspectos similares ao contexto do sistema escravista no século XIX, haja vista que a existência dos quilombos provocou desgastes não só ao escravismo enquanto categoria econômica, mas à sociedade escravista como um todo. Neste sentido, os quilombos, formados principalmente por

\footnotetext{
${ }^{98}$ Cf., dentre outras obras, REIS, João José e Flávio dos Santos GOMES (org.). Liberdade por um Fio: História dos Quilombos no Brasil. Cia. das Letras: São Paulo, 1996.

${ }^{99}$ GUIMAR ÃES, Carlos Magno. Escravismo e rebeldia escrava: Quilombos nas Minas Gerais do século XVIII. In: SILVA, Maria Beatriz Nizza da (Org.). Brasil - colonização e escravidão. Rio de Janeiro: Nova fronteira, 2000, p.325.
} 
escravos fugitivos, expressam uma contradição estrutural da realidade escravista, na medida em que retiram o escravo do processo produtivo e impossibilitam a reposição do capital nele investido, além de levar o governo e os proprietários de escravos a um consumo improdutivo com gastos exigidos na montagem de um sistema repressivo especializado - a exemplo das guerrilhas ${ }^{100}$ criadas no Espírito Santo - e dos prejuízos materiais advindos das ações dos quilombolas (tais como roubos, assaltos, incêndios, etc.), e das perdas dos impostos arrecadados pelo governo sobre o trabalho escravo. ${ }^{101}$

Nesta perspectiva, observamos que os presidentes da Província do Espírito Santo fazem diversas referências em seus relatórios acerca de fatos relacionados aos escravos e à escravidão, dentre os quais o tema dos quilombos e quilombolas aparece como um assunto que sempre preocupou as autoridades e os grandes proprietários da província, assim como toda a sociedade de uma maneira geral, já que estes representavam uma ameaça constante à ordem estabelecida, sobretudo nas décadas de 1840 e 1850, período que comporta a maior preocupação acerca deste assunto no âmbito governamental. Neste caso, novamente nos remetemos ao estudo de Guimarães sobre Minas ${ }^{102}$, no qual ressalta que, além dos desgastes materiais, a existência dos quilombos provocava outros tipos de desgastes importantes, tais como a negação da eficácia do aparato jurídicoideológico criado para prevenir fugas e punir fugitivos e quilombolas recapturados, além da existência de um medo permanente nas autoridades e na população em geral, devido às constantes ameaças de ataques quilombolas ou até mesmo da "má conduta" dos agentes encarregados da repressão aos quilombos.

No que tange aos tipos de quilombos e ao número de seus integrantes, nota-se que estes tanto podiam ser constituídos de populações reduzidas (menos de uma dezena de habitantes) como podiam atingir números significativos (centenas de quilombolas), cujo aumento da sua população poderia ocorrer em função da adesão de novos escravos fugidos e também da reprodução interna da própria população quilombola que

\footnotetext{
100 O termo guerrilha aqui tem a conotação original do termo que é "pequeno corpo irregular de guerreiros voluntários que atacam geralmente o inimigo fora de campo ou de emboscada; escaramuça; facção política sem elementos para constituir partido disciplinado". (v. Pequeno Dicionário Brasileiro da Língua Portuguesa, $11^{\mathrm{a}}$ edição, GAMMA/Editora Civilização Brasileira S.A., Rio de Janeiro, s/d.). No contexto do século XIX o termo não tem nenhuma relação com o sentido atual, o qual nos remete outros elementos como, por exemplo, oposição política, contestação e ideologia. As guerrilhas na Província do Espírito Santo eram constituídas por elementos contratados pelo Governo Provincial - assim como os famosos capitães-do-mato o eram por particulares - os quais recebiam 'soldos' para perseguição e captura de escravos fugitivos, combate a quilombolas e destruição de quilombos.

101 GUIMAR ̃̂ES, op. cit., p. 326.

102 Ibidem.
} 
constituía famílias naquelas situações em que a existência do quilombo permanecia por mais tempo, resistindo em meio às adversidades inerentes à sua natureza clandestina. No caso do Espírito Santo, as limitações impostas pelas fontes consultadas na elaboração deste estudo não nos permitiu dimensionar os quilombos quanto aos seus contingentes populacionais, haja vista que encontramos, quando muito, referências esporádicas e imprecisas acerca da caracterização dos mesmos, pois as autoridades enfatizavam aspectos negativos dos quilombolas com intuito de vulgarizar e desclassificar a sua existência e permanência no território capixaba.

Outro aspecto contemplado nas tentativas de caracterização dos quilombos diz respeito aos tipos de atividades desenvolvidas pelos mesmos, cuja variação geralmente é associada às diferentes condições sócio-econômicas e também naturais das distintas regiões brasileiras, onde os quilombolas poderiam se dedicar num leque de atividades que abarcavam coleta, agricultura, criação de animais, mineração, contrabando, saques e assaltos a tropas e fazendas, dentre outras formas de garantir a subsistência. Neste sentido, a região de São Mateus, enquanto grande produtora da farinha de mandioca, muito provavelmente comportou a existência de quilombos desenvolvendo essa mesma atividade, não somente para o sustento do agrupamento, mas também para negociar a produção excedente e adquirir outros produtos de que necessitavam. Contudo, há várias menções do governo provincial acerca de grupos de escravos fugitivos promovendo saques e assaltos aos viandantes e às propriedades agrícolas nas redondezas de São Mateus, sendo também recorrente nos relatórios da polícia a referência a este tipo de ação dos quilombolas em vários locais da província capixaba no Oitocentos.

Guimarães notou, com propriedade, que os quilombos são semelhantes por um lado e diferentes por outro, na medida em que tem em comum o fato de serem constituídos por escravos fugitivos em sua maior parte, mas se diferenciam porque cada quilombo tem sua época de existência, sua região e seus mecanismos de sobrevivência, cujos aspectos constituem uma configuração histórico-cultural específica.

No decorrer do período colonial, o Espírito Santo registrou diversos episódios envolvendo as relações conflituosas entre os colonizadores e os povos indígenas. No período, os índios representavam um grande percentual no quadro demográfico capixaba, sobretudo nos primeiros tempos do processo colonizador iniciado em 1534 com a divisão do país em Capitanias Hereditárias, quando muitos embates marcaram a relação entre os colonizadores portugueses e os povos indígenas da região. 
Os problemas relativos aos índios permaneceram no decorrer do Oitocentos. Contudo, neste novo contexto histórico, quando se registra o maior impulso de crescimento do contingente escravo existente na Província do Espírito Santo - em decorrência das transformações verificadas em suas estruturas agrárias, principalmente a partir da introdução da cafeicultura na região -, o foco de atenção das autoridades capixabas se volta, prioritariamente, para os diversos episódios e situações envolvendo as estratégias de resistência dos escravos.

Frente a esta situação, e sob pressão dos setores economicamente dominantes, as autoridades políticas regionais tomaram medidas visando a solução do problema, onde sobressaem as iniciativas de criação e formação de guerrilhas para captura de escravos fugidos e combate aos diversos quilombos existentes na província.

O tema referente à existência de um grande número de quilombos e as providências governamentais no sentido de reprimi-los e combatê-los, aparece com freqüência nos relatórios dos presidentes da província no decorrer do século XIX. No entanto, tais registros são mais incidentes no período anterior à proibição do tráfico, pois as práticas governamentais relativas à formação de guerrilhas para combate aos quilombolas remontam à década de 1840, conforme observa o Presidente Costa Pereira: “... como de todos os lados se clamasse contra o grande $\mathrm{n}^{\circ}$ de escravos que fugindo das casas dos seus senhores grupavam-se em diversos lugares, sobretudo perto dos povoados e dali corriam a atacar os viandantes e os lavradores das vizinhanças”, a Assembléia Provincial criou, pela lei de 29 de julho de 1845, uma guerrilha, com a missão de capturar esses escravos fugitivos e a destruir os seus quilombos. ${ }^{103}$

Portanto, é no transcurso das décadas de 1840 e de 1850 que se faz notória a menção das autoridades provinciais acerca da existência de um grande número de quilombos no território espírito-santense e das diversas tentativas frustradas de criação de guerrilhas para combatê-los. Neste contexto, a região de São Mateus aparece com destaque enquanto palco dessas manifestações, conforme constatamos nos registros referentes a esta questão em diversos relatórios presidenciais do período.

Nos anos finais da década de 1840, sobretudo nos relatórios presidenciais, as menções e queixas das autoridades provinciais acerca da proliferação dos quilombos no território espírito-santense, não somente tornaram-se mais freqüentes, como também

\footnotetext{
${ }^{103}$ Relatório do Presidente da Província do Espírito Santo José F. da Costa Pereira Jr, 23/05/1861, p. 18.
} 
aparecem carregadas de expressões de caráter pejorativo, com vistas a vulgarizar e desclassificar os fatos e o fenômeno em questão, conforme se abstrai na avaliação que o governo faz do problema dos quilombos em 1848, e na qual se evidencia também a existência de quilombos estabelecidos bem próximos às vilas e cidades da província: “... há porém um mal, e mal ingente, que para o futuro pode acarretar bem desagradáveis conseqüências, falo dos diversos ajuntamentos de negros fugidos, ou vulgarmente quilombos, que se acham constituídos mesmo ao pé dos povoados". ${ }^{104}$

Em outras fontes oficiais deste mesmo ano, constamos novas queixas das autoridades provinciais no que tange à inoperância do governo no sentido de combater "um dos graves problemas de segurança" no território capixaba, ou seja, a existência de "escravos fugidos que vivem reunidos em quilombos, nas matas". Conforme a avaliação do governo, a permanência destes representava uma grande ameaça ao desenvolvimento da agricultura como fonte primordial de prosperidade da província. ${ }^{105}$ Assim, em 1848, logo no início do seu relatório, o Vice Presidente Monjardim desabafa:

A propósito tratarei d'um mal ingente, que persegue esta província desde muitos anos, o qual ainda não pode ser extirpado, apesar dos esforços empregados pelas diversas administrações que hão se sucedido, e de alguns sacrifícios, não pequenos, do cofre provincial. Falo do grande número de escravos, que vivem juntos em quilombos, trazendo em contínuos sustos os fazendeiros. ${ }^{106}$

O clima de insegurança dos fazendeiros e proprietários de escravos diante da ameaça que os quilombos representavam à manutenção de suas riquezas e propriedades, é destacado no estudo de Vilma Almada ${ }^{107}$, quando esta observa que "nas fazendas a insegurança dos senhores chegava algumas vezes ao pânico, levando-os então a apelar para o Presidente da Província em busca de socorro". Acerca disto, cita o caso de um abaixo-assinado, realizado em 1847, onde consta a participação de 54 senhores solicitando providências do governo para a destruição dos quilombos de Araçatiba, Santo Agostinho, Lama Preta e Jacaraobas, no município de Vianna.

\footnotetext{
${ }^{104}$ Relatório do Presidente da Província Antonio Pereira Pinto, de 30/11/1848, p. 8 e 9. Biblioteca Digital do APEES.

${ }^{105}$ Relatório do Presidente da Província Luiz P. do Coutto Ferraz, de 01/03/1848, p.6 e 7. Biblioteca Digital do APEES.

${ }^{106}$ Relatório do Vice-Presidente da Província Jose F. de A. Monjardim, de 01/08/1848, p. 2. Biblioteca Digital do APEES.

${ }^{107}$ ALMADA, Vilma Paraíso F. de. Escravismo e Transição: o Espírito Santo (1850-1888). RJ: Edições Graal, 1984, p.138.
} 
Tal quadro não se altera nos anos subseqüentes, quando também constatamos diversas referências críticas acerca da presença dos quilombos no território capixaba, os quais, desta feita, são considerados pelo governo como um mal que deve ser extinto o quanto antes, pois atenta contra a tranqüilidade pública da província e poderá, no futuro, comprometer fortunas, bens e a própria existência de membros desta sociedade. E, exatamente por isto, as autoridades provinciais deveriam adotar medidas emergenciais para destruir os quilombos que formigão na província e tanto concorrem para o definhamento da agricultura e desmoralização da escravatura. ${ }^{108}$

Sendo assim, em meados do século XIX as autoridades provinciais ainda se debatiam em tentativas, geralmente frustradas, de criação de guerrilhas para a destruição dos quilombos e captura de escravos fugidos, cujos resultados, até então, eram insatisfatórios, não compensando os recursos investidos pelos cofres provinciais. Tal situação é objeto de destaque no relatório de Felippe Leal em $1850{ }^{109}$, quando o mesmo informa à Assembléia que "nada de profícuo se há podido conseguir a respeito dos quilombos, cuja existência é notória" na província, e na qual... "muitas tentativas hão-se feito para extirpar este terrível cancro da lavoura..., mas desgraçadamente tem sido elas frustradas, e por isso pesada ao cofre provincial”.

As justificativas das autoridades provinciais acerca do fracasso do governo na resolução dos problemas inerentes à resistência escrava no Espírito Santo se pautavam não somente na falta de recursos financeiros para melhor organizar e sustentar as guerrilhas de combate aos quilombolas e capturas de escravos fugitivos, mas também na existência de coiteiros ${ }^{110}$, o que tornava mais difícil a resolução de tais problemas, pois,

... desgraçadamente alem dos quilombos existem também indivíduos, que lavrão pequenos sítios com o serviço dos escravos fugidos. Contra estes principalmente convém desenvolver a maior vigilância, e direi mesmo toda a energia. (...)... dada a existência de semelhantes coitos em verdade ninguém pode contar com sua propriedade segura, por quanto ao menor aceno, à mais pequena ameaça os negros trocam pelos quilombos a casa de seus senhores.

\footnotetext{
108 Relatório do Presidente da Província Antonio J. de Siqueira, de 11/03/1849, p.7,15/16. Biblioteca Digital do APEES.

${ }^{109}$ Relatório do Presidente da Província Felippe J. P. Leal, de 25/07/1850, p. 9. Biblioteca Digital do APEES.

${ }^{110}$ Coiteiro ou Couteiro são denominações dadas aos indivíduos que dão asilo ou protegem "bandidos"- a citação destacada na sequiência do texto foi extraído no Relatório do Presidente Antonio Pereira Pinto, de 30/11/1848, p. 8 e 9. Biblioteca Digital do APEES.
} 
A existência de pessoas que acoitavam os escravos fugidos em suas propriedades foi muito debatida no âmbito governamental da província neste período, haja vista o destaque dado a este assunto nos relatórios presidenciais, nos quais se destaca que a proteção aos escravos fugidos era um procedimento funesto aos bens individuais, além de se constituir num fator de intranqüilidade pública, já que favorecia a continuidade das fugas e dos quilombos na província e, neste sentido, a polícia deveria dedicar "todo o empenho em descobrir algum desses acoitadores para serem punidos na forma da lei”.

Ainda sobre as ações dos coiteiros na província, Felippe Leal, em 1850, tece o seguinte comentário:

\footnotetext{
Julgo que enquanto se der o fato escandaloso de certos homens receberem escravos fugidos em suas casas, e com eles trabalharem e viverem em relações com os que se acham reunidos em quilombos, como é notório, semelhante mal continuará a pesar sobre a província, e sua agricultura acabar-se-á. (...) Se por ventura a policia quer cumprir seu dever, entrando no conhecimento deste negócio, ninguém, que tem certeza de tanto escândalo, e o testemunha quotidianamente, ousará descobrir os nomes desses homens, pois que o medo pela vida a faz cega e muda. ${ }^{111}$
}

A partir das informações e análises oriundas das principais autoridades públicas da província, fica evidente a precariedade e o despreparo que revestia a atuação do contingente policial existente no Espírito Santo à época. A alegação para este quadro, presente na maioria dos relatórios presidenciais, diz respeito à escassez de recursos financeiros nos cofres públicos provinciais, considerada o principal empecilho de melhorias na segurança pública regional. Tal situação fica patente, quando se observa a polêmica instaurada nas instâncias governamentais acerca da criação das guerrilhas de combate aos quilombos na província, cujo assunto foi objeto de análise crítica em vários relatórios presidenciais, sobretudo nos anos subseqüentes à criação da primeira lei com este fim, a saber, a Lei $n^{\circ} 8$, de 29 de julho de 1845.

Nesta perspectiva, em 1848, o governo informa que fez o que pode "para levar avante algumas diligencias, a fim de bater esses quilombos com as precisas cautelas, e com o devido segredo e reserva", mas, estas não surtiram efeito algum, pois, a lei criada em 1845 apresenta lacunas nos procedimentos relativos à criação de guerrilhas de combate aos quilombolas na província. Nesta mesma ocasião, nota-se que o fracasso das

\footnotetext{
${ }^{111}$ Relatório do Presidente da Província Felippe J. P. Leal, de 25/07/1850, p. 10. Biblioteca Digital do
} APEES. 
guerrilhas se devia à ausência de um "comandante corajoso e responsável” na condução de tal empreitada, o que somente seria viável se o governo concedesse certos privilégios de remuneração e segurança pessoal a este cargo, e autorizasse o executivo a "engajar um comandante para a guerrilha permanente por ele criada, o qual tenha vencimentos seguros e fixos que o ponham a abrigo de maiores necessidades, e permitam a sua residência na capital, quando não lhe for necessário bater as matas”. Esta necessidade decorria dos fatos "desgraçados" já ocorridos, de atentados e vinganças contra os comandantes das guerrilhas, criando receios nos indivíduos pretendentes ao cargo. ${ }^{112}$

Tal sugestão de alteração na lei de criação das guerrilhas foi acatada pela Assembléia Provincial ainda em 1848, conforme registro feito pelo governo sucessor: "A lei provincial n. ${ }^{\circ} 8$ de 31 de julho de 1845, que criou uma guerrilha para empregar-se na batida de tais quilombos, foi substituída pela de n. $^{\circ} 8$ datada de 4 de maio d'este ano, e esta satisfaz convenientemente as necessidades de semelhante serviço", posto que, além de outras mudanças, tornou permanente o cargo do comandante da guerrilha, com o soldo de $500 \$ 000$ réis anuais. ${ }^{113}$

Mesmo com as alterações na lei referente à criação de guerrilhas de combate aos quilombos, as iniciativas do governo nesta área, além de contar com parcos recursos financeiros, não obtinha resultados que justificassem tais investimentos públicos e a criação de novas guerrilhas, já que os recorrentes fracassos destas tornaram-se alvos de críticas aguçadas no âmbito político-administrativo da província no decorrer do período.

No conjunto das fontes oficiais consultadas, e no tocante ao problema dos quilombos e dos escravos fugitivos na província, a maioria das queixas das autoridades provinciais se refere à escassez dos recursos materiais e humanos destinados pelo governo central e provincial para solucionar tais questões, com destaque para a precariedade que marca a composição dos quadros das respectivas guerrilhas criadas.

A polêmica instaurada no âmbito governamental da província, acerca da manutenção ou da extinção das guerrilhas enquanto estratégia de combate aos quilombolas no território espírito-santense é objeto de destaque, sobretudo nos anos finais da década de 1850, quando o governo provincial admite que o "serviço das guerrilhas tem sido dispensado com vantagem para os cofres públicos”.

\footnotetext{
${ }^{112}$ Relatório do Presidente da Província Luiz P. do Coutto Ferraz, de 01/03/1848, p. 6 e 7. Biblioteca Digital do APEES.

${ }^{113}$ Relatório do Vice-Presidente da Província Jose F. de A. Monjardim, de 01/08/1848, p. 2. Biblioteca Digital do APEES.
} 
A partir de 1859, nota-se o acirramento das críticas do governo às guerrilhas criadas para combate aos quilombos na província, cujas manifestações sobressaem em diversos relatórios presidenciais, a exemplo das análises do Presidente Leão Velloso, quando observa que “... se pela lei provincial está a presidência autorizada a criar guerrilhas na capital, em São Mateus e na Serra, a experiência, porém, tem mostrado a inconveniência de tal espécie de força, se tal nome pode merecer”. Ressalta ainda que a guerrilha não se encontra organizada e que "nenhum serviço presta, causando aliás crescidas despesas aos cofres provinciais, quando saem a diligencias...". ${ }^{114}$

Devemos, contudo, atentar para o fato de que, nos relatórios presidenciais do período, muitas questões e argumentos foram construídos com intuitos e interesses políticos diversos, pois, eram nesses relatórios que os sucessivos presidentes prestavam contas à Assembléia Legislativa Provincial acerca das suas ações e dos recursos dos cofres provinciais direcionados à formação das guerrilhas de combate aos quilombos. Nestes, geralmente, foram registradas queixas e lamentações relativas à falta de numerário nos cofres públicos para a adoção de medidas nesta área, do que decorria a fragilidade e precariedade do aparato policial da província e, conseqüentemente, as restrições imposta às ações do executivo na resolução de tais problemas - a exemplo das justificativas do Presidente Ferraz à Assembléia em 1848, quando aponta a escassez de verbas e a ineficiência da força policial como causa do fracasso das guerrilhas, onde “muitas vezes o governo provincial sentiu-se impotente para oferecer ajuda efetiva".

Nesta mesma perspectiva, é oportuno destacar as considerações tecidas pelo Presidente Leal em $1850{ }^{115}$, quando avalia criticamente a criação e a atuação das guerrilhas de combate aos quilombos na província, alegando que, apesar da presidência muito desejar "prover de remédio a necessidade palpitante que sente a Província de aniquilação desse flagelo", o governo não dispunha de recursos, assim como nas tentativas anteriores de formação das guerrilhas, as quais não foram devidamente organizadas, pois reunia "gente, que não pode incutir a confiança que demanda uma força de tanta importância, e que se alista levada pela mira no salário, havendo até o fato de ser a própria que avisa qualquer movimento que vai ter". Nessas condições, era praticamente impossível manter o segredo exigido por empreitadas desse tipo. Todavia, ressalta que pretendia mandar "alistar algumas praças" para marcharem em diligência a

\footnotetext{
${ }^{114}$ Relatório do Presidente da Província Pedro Leão Velloso, de 25/05/1859 (Appenso A - Polícia, p. 8). Biblioteca Digital do APEES.

${ }^{115}$ Relatório do Presidente Felippe J. P. Leal, de 25/07/1850, p. 10 e 11. Biblioteca Digital do APEES.
} 
um dos lugares onde consta existirem "reuniões de negros fugidos", mas, em conseqüência da "falta de numerário nos cofres", nada pode fazer a este respeito.

$\mathrm{Na}$ seqüência do período, também são feitas referências à criação de uma guerrilha na Comarca de São Mateus (Lei n ${ }^{\circ} .19$ de 28 de julho de 1852), a qual não pode ser organizada por falta de verbas, cujas despesas não foram previstas no orçamento. Na ocasião, a manutenção das guerrilhas de combate aos quilombos foi novamente questionada, quando se propôs a redução do contingente guerrilheiro para diminuição de gastos, com vistas a aumentar as cifras do aparato policial permanente e "regular". Esta sugestão se amparou numa avaliação negativa do governo acerca da atuação das guerrilhas, as quais não respondiam aos fins da sua criação, pois: "o que de princípio ia produzindo de bom resultado, pelo que apenas oito quilombolas têm sido apreendidos, quando, segundo o que geralmente consta, muitos são os escravos acoitados por essas matas".

Assim, além de sugerir a redução do número de guerrilheiros (que deveriam residir na capital para estarem prontos em atender a qualquer chamado), o governo provincial propunha ainda que os vencimentos destes fossem marcados por diárias, as quais seriam suprimidas quando saíssem em diligências para as apreensões, visto que nesses casos teriam direito ao pagamento dos senhores dos aquilombados, e cujo valor deveria ser maior do que aquele estabelecido na legislação provincial (Lei $\mathrm{n}^{\circ}$. 8, de 4/5/1848). Com isto, o governo esperava que as guerrilhas se empenhassem com maior afinco nas diligências e realizassem maior número de apreensões de quilombolas. ${ }^{116}$

Os propósitos governamentais de reduzir as despesas das guerrilhas "visando maior investimento nas melhorias da força pública", são reafirmados em meados da década de 1850, quando se destaca que "o sistema de guerrilhas não tem apresentado bons resultados; e, com efeito, nada de bom se pode esperar de uma força desorganizada, e sem a menor disciplina". Neste sentido, a despesa com guerrilhas foi suprimida do orçamento provincial em 1855 - “excetuando a quantia de $400 \$ 000$ réis com o comandante da de $\mathrm{S}$. Matheus", onde tal sistema será mantido, devido às dificuldades de transporte de qualquer força àquela localidade pela distância, e também porque as despesas com a sua manutenção são "diminutas". ${ }^{117}$

\footnotetext{
${ }^{116}$ Relatório do Presidente da Província Evaristo Ladislau Silva, de 23/05/1853, p.12 e 14. Biblioteca Digital do APEES.

${ }^{117}$ Relatório do Presidente da Província Sebastião M. Nunes, de 25/05/1854, p. 13,14 e 48. Biblioteca Digital do APEES.
} 
Levando-se em conta a precariedade das guerrilhas de combate aos quilombos, podemos inferir que, dentre outros fatores, esta situação se apresentava como propícia à deflagração das revoltas escravas verificadas na província no século XIX, cujas evidências são também encontradas na documentação oficial, onde diversas ocorrências ou "ameaças" de insurreições escravas, abarcando vários pontos do território espíritosantense, são mencionadas pelas autoridades da província à época. Assim, das revoltas ou insurreições escravas ocorridas na província capixaba na segunda metade do Oitocentos, constatamos que a chamada Insurreição do Queimado, ocorrida em 1849, tornou-se referência e destaque, não somente nos relatórios presidenciais, mas também nos estudos mais recentes acerca da escravidão no Espírito Santo, nos quais sempre consta a menção desta enquanto fato ocorrido e registrado na documentação oficial. ${ }^{118}$

Esta reação escrava teve lugar na antiga Freguesia de São José do Queimado ${ }^{119}$, e durou apenas cinco dias, ou seja, até a prisão dos líderes do movimento, a saber: o escravo Elisiário, que fugiu da cadeia (formando posteriormente um quilombo na região próxima ao Morro do Mestre Álvaro na Serra) e mais dois escravos - Chico Prego e João da Viúva Monteiro - que foram condenados à forca.

Nesta insurreição, se destaca a participação diferenciada de dois religiosos, haja vista que o advogado dos escravos revoltosos foi o padre João Clímaco de Alvarenga Rangel, o qual possuía propriedade na Serra e que teve alguns dos seus escravos envolvidos na rebelião (por isto julgou justo defendê-los), mas que nada pôde fazer para inocentá-los, e frei Gregório Maria de Bene, missionário capuchinho, considerado o responsável pela insurreição e "o único capaz de receber a imputação do crime". ${ }^{120}$

Sobre este acontecimento, o governo provincial do período ${ }^{121}$ informou que foram executados dois líderes da insurreição, sendo que, para isto, foram remetidos dois “algozes" da corte, cuja operação custou aos cofres provinciais 274\$920 réis (transporte de ida e volta destes e de mais cinco "permanentes" que os escoltaram). Sobre os outros "cabeças" da insurreição, estes não foram executados, pois fugiram da cadeia de Vitória

\footnotetext{
${ }^{118}$ Cf. CAMPOS, Adriana Pereira. Abolicionistas, Negros e Escravidão. Dimensões - Revista de História da UFES, n. 10, jan. jul./2000.

${ }^{119}$ Freguesia criada em meados do século XIX e posteriormente incorporada ao município da Serra-ES, situado no entorno da Capital e integrante da atual área metropolitana denominada "Grande Vitória".

${ }^{120}$ Cf. BORGES, Clério José. A Revolta do Queimado - Negros em busca de liberdade. Livro de História da Serra, Serra-ES: Edições do autor, 1998.

${ }^{121}$ Relatório do Presidente da Província Felippe J. P. Leal, de 25/07/1850, p. 11. Biblioteca Digital do APEES.
} 
onde estavam presos, os quais, mesmo com as prontas providências tomadas pelas autoridades acerca da 'fuga desses malvados', os mesmos não foram mais capturados.

Após o episódio do Queimado, o foco de atenção das autoridades capixabas se voltou para a região norte da província, quando houve ameaça de uma insurreição de escravos na Freguesia de São Mateus, em 1851. Acerca disto, o Presidente d'Azambuja registra que foram feitos consertos no quartel do destacamento da cidade de São Mateus (que estava quase caindo), cuja despesa importou em 101\$740 réis, sendo necessária tal obra, pela urgência de para lá enviar-se um forte destacamento devido aos receios de uma insurreição de escravos. Contudo, ressalta que tal episódio não exerceu a menor influência na tranqüilidade pública, posto que "se desvaneceu em pouco tempo". ${ }^{122}$ Não obstante, o governo chama atenção acerca da necessidade "palpitante" de se conceder alguns fundos "para serem despendidos com guerrilhas que batam os muitos e povoados quilombos que tem a Província, onde estão acoitados inúmeros escravos, os quais representam grande perigo e podem causar diversos prejuízos à sociedade capixaba”.

Sendo assim, novamente na década de 1860 , o governo provincial ${ }^{123}$, ao mesmo tempo em que elogiava a 'índole pacífica dos espírito-santenses', destacava também que 'em alguns pontos da Província se receava uma insurreição de escravos', devido aos boatos existentes em seu meio, de que os acontecimentos da Guerra do Paraguai levariam à emancipação dos cativos. Diante disto, foram adotadas medidas para frustrar qualquer tentativa a esse respeito e restabelecer a calma nos 'espíritos mais exaltados'.

Contudo, no ano seguinte esta mesma situação torna-se objeto de preocupação das autoridades provinciais, quando surgem boatos 'de que uma insurreição de escravos se preparava em S. Matheus e Itapemirim', fazendo com que o Presidente ${ }^{124}$, mesmo considerando tais boatos 'infundados', adotasse medidas preventivas para 'tranqüilizar o espírito público', enviando o Chefe de Polícia interino a São Mateus e reforçando o destacamento policial em Itapemirim. Porém, conforme a previsão do governo, mais uma vez os boatos não tiveram consistência alguma e logo se desvaneceram.

Ao observar e analisar os dados referentes à composição e à distribuição espacial da população capixaba em 1856 percebe-se que tal quadro demográfico pode contribuir

\footnotetext{
${ }^{122}$ Relatório do Presidente da Província José B. N. d'Azambuja, de 24/05/1852, p.17 e 49. Biblioteca Digital do APEES.

${ }^{123}$ Relatório do Presidente da Província José Joaquim do Carmo, de 26/05/1865, p. 5. Biblioteca Digital do APEES.

${ }^{124}$ Relatório do Presidente da Província Alexandre R. da Silva Chaves, de 25/05/1866, p. 6. Biblioteca Digital do APEES.
} 
na elucidação de certos aspectos relacionados à ocorrência e/ou ameaças das revoltas escravas registradas pelos presidentes da província à época. Assim, o levantamento estatístico populacional de 1856 aponta um total de 48.855 habitantes no território espírito-santense, no qual se inclui 12.100 cativos, correspondendo a $24,8 \%$ do total dos habitantes levantados pelo censo. Ou seja, a população escrava abarcava em torno de $1 / 4$ do total desta população, demonstrando a existência de um expressivo contingente de escravos nos quadros demográficos da província neste período. Por outro lado, neste mesmo quadro demográfico, são notadas diferenças e especificidades relativas à distribuição numérica e percentual da população livre e da população escrava nos cinco Termos existentes na província, conforme a disposição dos dados específicos de cada núcleo populacional da província, discriminados na Tabela 1.

Tabela 1: População da Província do Espírito Santo em 1856.

\begin{tabular}{|c|c|c|c|c|c|c|c|}
\hline Distritos & Fogos & $\begin{array}{c}\text { Pop. } \\
\text { Livre }\end{array}$ & $\begin{array}{c}\% \\
\text { P. L. }\end{array}$ & $\begin{array}{c}\text { Pop. } \\
\text { Escrava }\end{array}$ & $\begin{array}{c}\% \\
\text { P. E. }\end{array}$ & $\begin{array}{r}\text { Total } \\
\text { Pop. }\end{array}$ & $\begin{array}{c}\% \\
\text { Total }\end{array}$ \\
\hline Capital & 1.075 & 4.139 & - & 863 & - & - & - \\
\hline Cariacica & 524 & 3.253 & - & 896 & - & - & - \\
\hline Vianna & 363 & 2.228 & - & 1.274 & - & - & - \\
\hline Mangarahy & 336 & 1.388 & - & 316 & - & - & - \\
\hline Carapina & 186 & 1.125 & - & 205 & - & - & - \\
\hline \multirow[t]{2}{*}{ Espírito Santo } & 236 & 1.031 & - & 280 & - & - & - \\
\hline & & 13.164 & 26,9 & 3.834 & 7,9 & 16.998 & 34,8 \\
\hline Serra & 319 & 2.004 & - & 520 & - & - & - \\
\hline Queimado & 172 & 919 & - & 569 & - & - & - \\
\hline N. Almeida & 262 & 2.048 & - & 465 & - & - & - \\
\hline Santa Cruz & 704 & 2.586 & - & 251 & - & - & - \\
\hline \multirow[t]{2}{*}{ Linhares } & 333 & 928 & & 36 & - & - & - \\
\hline & & 8.485 & 17,3 & 1.841 & 3,7 & 10.326 & 21,2 \\
\hline C. de S. Matheus & 524 & 1.743 & - & 1.859 & - & - & - \\
\hline \multirow[t]{2}{*}{ B. de S. Matheus } & 325 & 1.859 & - & 354 & - & - & - \\
\hline & & 3.602 & 7,5 & 2.213 & 4,5 & 5.815 & 12,0 \\
\hline Guarapary & 399 & 2.924 & - & 213 & - & - & - \\
\hline Benevente & 363 & 2.518 & - & 412 & - & - & - \\
\hline \multirow{2}{*}{ Piuma } & 145 & 994 & - & 133 & - & - & - \\
\hline & & 6.536 & 13,4 & 758 & 1,6 & 7.294 & 14,9 \\
\hline Itapemirim & 428 & 2.508 & - & 1.885 & - & - & - \\
\hline Cachoeiro & 200 & 1.494 & - & 1.254 & - & - & - \\
\hline \multirow[t]{2}{*}{ Itabapoana } & 185 & 986 & - & 315 & - & & \\
\hline & & 4.968 & 10,1 & 3.454 & 7,1 & 8.422 & 17,1 \\
\hline TOTAL & 7.079 & 36.793 & 75,2 & 12.100 & 24,8 & 48.855 & 100,0 \\
\hline
\end{tabular}

Fonte: Relatório do Presidente da Província do Espírito Santo José Maurício F. P. de Barros, de 13/02/1857, p. 9 e 10 - Biblioteca Digital do APEES. 
Neste quadro demográfico de 1856, percebe-se que nos Termos de São Mateus e do Itapemirim, a proporção diferencial entre o quantitativo da população livre e da população escrava, se apresenta bem mais tênue do que nas outras áreas da província. Assim, no caso do núcleo populacional de São Mateus, no total dos 5.815 habitantes, a população livre somava 3.602 habitantes e a população escrava somava 2.213 habitantes e, no núcleo populacional do Itapemirim, no total de 8.422 habitantes, a população livre somava 4.968 habitantes e a população escrava somava 3.454 habitantes. Neste sentido, pode-se inferir que a composição dos quadros demográficos dessas duas regiões, em certa medida, justifica o temor que se instaurava nessas duas localidades quando afloravam boatos e ameaças relativas à eclosão de revoltas ou insurreições escravas.

Apesar das muitas ameaças de revoltas escravas não se concretizarem na província, diversos atos governamentais relacionados às formas de reação escrava são registrados no transcurso da década 1860 e nos anos subseqüentes. Tanto é assim que, em $1864{ }^{125}$, o governo informava que, além das três classes que formavam a polícia da província, existia ainda "uma companhia de guerrilha com a única missão de capturar escravos fugidos" (criada pela Lei $\mathrm{n}^{\circ} 8$, de 24 de julho de 1861), composta por um comandante (com a gratificação de $500 \$ 000$ réis) mais os "20 engajados vencendo a gratificação de $2 \$ 000$ réis por cada dia que se empregam em diligencias”. Porém, ressaltava-se que esta Companhia estava muito aquém de corresponder aos objetivos da sua criação, pois, "só de longe em longe aparece um escravo por ela capturado, entre os muitos que por aí andam foragidos, e isto mesmo com avultada despesa para os cofres provinciais" e da pesada contribuição para os respectivos senhores de escravos.

Acerca disto, o Presidente Pindahiba notava que, no transcurso de 14 meses (de julho de 1863 a setembro de 1864) foram apreendidos apenas nove escravos que estavam realmente fugidos, cujos serviços custaram aos cofres provinciais a quantia de 1:035\$305 réis (com as gratificações pelos dias despendidos nas diligências), mais a importância de $208 \$ 000$ réis que os donos desses escravos repartiram entre os praças da guerrilha, o que perfazia um total de 1:243\$305 réis, e cujo valor, dividido pelo número de escravos apreendidos, apresentava um custo de $138 \$ 145$ réis por escravo capturado.

Portanto, com base neste cálculo, o governo propunha a extinção desta Companhia, por considerar tal despesa excessiva, não somente pela escassez dos

\footnotetext{
${ }^{125}$ Relatório do Presidente da Província Eduardo Pindahiba Mattos, de 3/10/1864, p.61,71,72. Biblioteca Digital do APEES
} 
recursos públicos da província, mas, sobretudo, pelo pouco trabalho que os 'guerrilheiros' dedicavam a este serviço, cuja esfera de ação não ia além de quatro a seis léguas a partir da capital, além de ser um serviço "mal feito e de difícil, senão, impossível fiscalização, dando mesmo lugar a abusos quase inevitáveis”. ${ }^{126}$

Apesar das recorrentes análises críticas e de todas as avaliações negativas feitas pelas autoridades políticas em relação à criação, desempenho e manutenção dessas guerrilhas de combate aos quilombos no Espírito Santo, os sucessivos governos provinciais, por falta de alternativa, lançavam mão deste expediente, com vistas a solucionar ou minimizar os graves problemas gerados pelas inúmeras fugas de escravos e pela multiplicação dos quilombos no território capixaba. E, mesmo diminuindo de intensidade nos idos de 1870 e de 1880, a criação dessas guerrilhas ainda permaneceu como prática governamental, haja vista que nos fins da década de 1870 se registra a decretação de outra lei que "autoriza o Presidente da Província a criar uma Guerrilha para captura de escravos fugidos e destruição de quilombos" (Lei n ${ }^{\circ} 9$, de 9 de agosto de 1877), a qual será também utilizada em meados da década de 1880, quando o governo, diante dos boatos de escravos fugidos vagando pelas estradas e ameaçando a tranqüilidade pública, por Ato de 23 de julho de $1885^{127}$, cria novamente uma Guerrilha (composta de dez praças e um comandante) para capturá-los e destruir seus quilombos. Porém, em 23 de setembro de 1885, o governo suspende a execução deste Ato, ao perceber que tal serviço era feito irregularmente e também que essas despesas oneravam os cofres públicos.

Com base nos dados discriminados na Tabela 2, fica evidenciada a tendência de redução do contingente escravo do Espírito Santo a partir da segunda metade dos anos de 1870, a qual se torna mais acentuada no transcurso da década de 1880.

\footnotetext{
${ }^{126}$ Relatório do Presidente da Província Eduardo Pindahiba de Mattos, de 03/10/1864, p. 61,71 e 72. Biblioteca Digital do APEES.

${ }^{127}$ Relatório do Vice-Presidente da Província Manoel Ribeiro C. Mascarenhas, de 02/10/1885. Biblioteca Digital do APEES.
} 
Tabela 2: Declínio da população escrava no ES (1872 a 1887).

\begin{tabular}{lc}
\hline ANO & $\mathrm{N}^{\circ}$. DE ESCRAVOS \\
\hline 1872 & 22.659 \\
1874 & 22.738 \\
1878 & 20.862 \\
1879 & 20.788 \\
1880 & 20.638 \\
1881 & 20.597 \\
1884 & 20.216 \\
1885 & 19.762 \\
1887 & 13.382 \\
\hline
\end{tabular}

Fonte: SALETTO, Nara. Transição para o trabalho livre e Pequena propriedade no Espírito Santo (1888-1930). Vitória: EDUFES, 1996, p. $78 .{ }^{128}$

No intervalo de tempo abarcado pela Tabela 2, diversos fatores de ordem interna e externa contribuíram na diminuição do quantitativo dos escravos na província, dentre os quais podemos destacar: a introdução de imigrantes estrangeiros na província, a intensificação do movimento abolicionista no país, a criação dos fundos de emancipação de escravos pelo governo central e provincial, além do consequiente aumento das concessões de alforrias. Neste contexto, pode-se compreender, então, a concomitante redução das guerrilhas de combate aos quilombos na província à época.

Não obstante, na conjuntura escravista de meados da década de 1880, quando várias situações já apontavam para a derrocada do sistema escravista no Brasil, Almada destaca que as reações escravas generalizaram-se também na província capixaba, pois além dos registros das diversas fugas de escravos, houve também uma tentativa de insurreição em São Mateus, em janeiro de 1885, quando foi processado, como cabeça do movimento, Francisco Mota. ${ }^{129}$

Martins ressalta que ao longo do século XIX, os escravos aproveitavam o momento das comemorações religiosas para planejar grandes revoltas. Segundo o autor, “os fatos verificados em São Matheus elucidam um pouco mais este costume, bem como o papel da imprensa, ao ocultar os eventos capazes de promover o pânico na sociedade da época”. Destaca o papel da imprensa e o da polícia ante a denúncia de um plano de revolta escrava "planejado para ocorrer em meio às comemorações em louvor

128 Dados retirados por SALETTO nas seguintes fontes: Recenseamento de 1872; Relatórios do Ministério da Agricultura - 1875, 1887, 1889; Relatório do Ministério do Império de 1883, e Relatório da Diretoria Geral de Estatística em 1876.

${ }^{129}$ ALMADA, Vilma Paraíso Ferreira de. Escravismo e Transição: o Espírito Santo (1850-1888). R.J.: Edições Graal, 1984. p. 201. 
a Sant'Anna, no dia 27 de julho de 1884, em São Matheus, norte da Província do Espírito Santo, com a finalidade de promover a emancipação geral dos escravos do município". ${ }^{130}$

Enfim, do exposto acima, ressaltamos que os fatos e as análises apresentados ao longo deste texto, requerem maiores estudos no sentido de gerar proposições mais definidas acerca do tema em foco. Não obstante, consideramos que as questões centrais colocadas aqui, além de motivar e subsidiar novas pesquisas sobre a temática em foco apresenta também algumas contribuições ao conjunto de conhecimentos sobre a escravidão na província capixaba. Dentre essas questões podemos destacar:

I) A política de combate aos quilombolas na Província do Espírito Santo no decorrer do Oitocentos se revestiu de um forte aparato legal, haja vista o variado leque de leis e decretos que respaldaram as ações empreendidas pelo governo nesta matéria, sobretudo aquelas que autorizaram investimentos dos cofres provinciais na criação e manutenção das guerrilhas para a captura de escravos fugitivos e destruição dos quilombos, conforme relação que se segue:

1. Lei $\mathrm{n}^{\mathrm{o}} 8$, de 29 de julho de1845 - Cria uma guerrilha para prender criminosos $e$ escravos fugitivos;

2. Lei $\mathrm{n}^{\circ} 8$, de 27 de julho de 1846 - Determina que a multa estabelecida no art. $9^{\circ}$ da Lei 8, de 28 de julho de 1845, seja dividida entre os que capturarem os escravos fugitivos;

3. Lei $\mathrm{n}^{\circ} 8$, de 4 de maio de 1848 - Cria uma guerrilha destinada à captura de criminosos e escravos fugitivos;

4. Lei $\mathrm{n}^{\mathrm{o}} 19$, de 28 de julho de 1852 - Cria uma guerrilha na Comarca de São Mateus, destinada a captura de escravos fugitivos, desertores e criminosos;

5. Dec. $\mathrm{n}^{\mathrm{o}} 12$ (329), de 5 de julho de 1858 - Cria na Vila da Serra uma guerrilha destinada à captura de escravos fugitivos, desertores e criminosos;

6. Lei $\mathrm{n}^{\mathrm{o}} 8$, de 24 de julho de 1861 - Cria uma companhia de guerrilha com a única missão de capturar escravos fugidos;

7. Dec. $\mathrm{n}^{\mathrm{o}} 20$ (516), de 12 de agosto de 1865 - Vigora a Lei 19, de 28 de junho de 1852 que criou na Cidade de São Mateus uma guerrilha;

${ }^{130}$ Cf. MARTINS, Robson L. M.. Em louvor a Sant'Anna: notas sobre um plano de revolta escrava em São Mateus, norte do Espírito Santo, Brasil, em 1884. Estudos Afro-Asiáticos, n. 38, Rio de janeiro, dez. 2000. 
8. Dec. $\mathrm{n}^{\circ} 9$ (550), de 3 de julho de 1867 - Cria no Termo de Itapemirim uma guerrilha que se empregará na captura de escravos e criminosos;

9. Dec. $\mathrm{n}^{\mathrm{o}} 7$ (586), de 31 de outubro de 1868 - Extingue a guerrilha criada pela Lei 9, de 3 de julho de 1867, no Município de Itapemirim;

10. Lei ${ }^{\circ}$ 9, de 9 de agosto de 1877 - Autoriza o Presidente da Província a criar uma Guerrilha para captura de escravos fugitivos e destruição de quilombos;

11. Ato de 23 de julho de 1885 - Com base na Lei 9 de 1877, o governo cria uma Guerrilha (composta de dez praças e um comandante) para captura de escravos fugidos e destruição dos quilombos;

12. Ato de 23 de setembro de 1885 - Através do qual o governo suspende a guerrilha criada pelo Ato de 23 de julho de 1885 ;

II) Mesmo com todas as medidas legais adotadas pelo governo provincial para conter a revolta e a resistência dos escravos à instituição escravista, os resultados obtidos nessas empreitadas não foram satisfatórios, cujas principais alegações para tal fracasso foram: a escassez dos recursos públicos, a precariedade na composição das guerrilhas criadas e a existência de um grande número de coiteiros de escravos na província;

III) A incapacidade das autoridades provinciais em conter a proliferação dos quilombos no território espírito-santense, leva o governo a solicitar também a colaboração dos fazendeiros interessados na recuperação de suas escravarias, cuja principal evidência registrada nos relatórios presidenciais, se refere à contribuição dos "senhores dos aquilombados" no pagamento de diárias aos componentes das guerrilhas criadas;

IV) $\mathrm{Na}$ matriz discursiva do governo provincial acerca dos problemas gerados pela fuga de escravos e pela formação de muitos quilombos no território capixaba, sobressai a questão da dependência do setor produtivo da agricultura regional face à manutenção do trabalho escravo, pois, a proliferação dos quilombos era tida como o "terrível cancro da lavoura da província", devendo ser contida, pois senão a "sua agricultura acabar-se-á";

V) Ainda nesta matriz discursiva oficial, a fuga dos escravos e os quilombos aparecem como o grande terror que prejudica a segurança e a tranqüilidade pública "trazendo em contínuos sustos os fazendeiros", além de representarem uma séria ameaça ao direito de propriedade, bens e fortunas dos membros da sociedade regional e que, por isto, deveriam ser "extirpados", "aniquilados" e "destruídos".

Enfim, esse conjunto de ações e providências tomadas pelo governo provincial, para conter a resistência e as reações escravas no território capixaba, percorre todo o 
período analisado, demonstrando que as guerrilhas de captura dos escravos fugidos e de combate aos quilombos, foram recursos utilizados no Espírito Santo até praticamente as vésperas da Abolição.

Polícia, Justiça e Escravidão.

Neste tópico, dedicamos atenção especial a diversas situações policiais e judiciárias verificadas no Espírito Santo na segunda metade do século XIX, nas quais, direta ou indiretamente, os escravos foram objeto de inquéritos, julgamentos e/ou ocorrências policiais de vários tipos, cujos registros são mencionados nas fontes oficiais, haja vista que tais casos exigiam a atuação e o posicionamento do aparato policial e judiciário da província. Os fatos e situações desta natureza são geralmente destacados no item "Segurança e Tranqüilidade Pública da Província”, recorrente em praticamente todos os relatórios presidenciais consultados nesta pesquisa.

Dentre estes, destacaremos aqueles que possibilitam uma avaliação mais ampla acerca do posicionamento das autoridades provinciais diante dos crimes ou situações enquadradas no âmbito da justiça, onde os escravos comparecem como personagens principais da trama, ora como réus ora como vítimas. Em se tratando dos escravos réus, estes eram sempre "culpados", presos e, conforme a gravidade do crime praticado, condenados à pena de morte. A exemplo disto, destaca-se que em uma sessão do júri de Itapemirim, foram julgados diversos réus, onde "33 réus livres se apresentarão a serem julgados, e todos foram absolvidos, saindo, entretanto condenados os três únicos escravos, que foram julgados". ${ }^{131}$

É quase consenso nos relatórios presidenciais, o atraso da Justiça e a falta de magistrados na província, fatos esses que sempre contribuíam para agravar o estado das questões que dependiam do posicionamento do Judiciário, além de facilitar os abusos de poder em tais matérias. Neste aspecto, os presidentes da província não se cansavam de denunciar a deficiência da Justiça, a falta de cultura e imparcialidade dos Juízes, sendo mesmo notório o comprometimento da Justiça com os poderosos do lugar - a exemplo do depoimento de Costa Pereira em 1861, onde afirma que os juízes da província “estão

\footnotetext{
${ }^{131}$ Relatório do Presidente da Província Pedro Leão Velloso, de 25/5/1859, p. 12. Biblioteca Digital do APEES.
} 
longe da posição vantajosa que a importância do cargo e a responsabilidade do ministério deviam ter criado. Pobres e dependentes sofrem privações...". ${ }^{132}$

Almada afirma que o sistema escravista, ao apoiar-se na submissão absoluta e na obediência ilimitada do negro ao seu proprietário, não poderia permitir o menor desacato a este, sob pena de comprometer toda a ordem social: "baseado na sujeição pessoal, o sistema escravista só poderia manter-se pela opressão, e a Lei, expressão da sociedade, não tinha alternativa senão curvar-se ante essa evidência." ${ }^{133}$

Ao final da década de 1850, o governo observava que dentre os "crimes mais notáveis" ocorridos na província naqueles últimos tempos, estavam aqueles praticados por escravos contra os seus senhores, cujos principais foram:

Em 1855 o assassinato de Joaquim Alves de Vasconcellos, morto a golpes de machado por 2 escravos, em 1857 o de Manoel José de Mattos, também morto por 2 escravos que em uma fogueira queimarão o cadáver; o grave ferimento de Maria Lopes de Oliveira por uma escrava, que acometeu sua senhora com uma mão de pilão; a morte de uma escrava por bárbaros castigos, e finalmente a morte de 2 mulheres por seus maridos. ${ }^{134}$

Acerca do primeiro crime referido na citação anterior, o Barão de Itapemirim informou que este ocorreu no sul da província, em 1855, quando "Joaquim Alves de Vasconcellos, morador do distrito de Itabapoana, foi ahi assassinado a 17 de novembro último por dois de seus escravos, que logo se evadiram; graças a diligencias da polícia foram depois capturados, tendo sido já pronunciados, corre o processo seus termos". Com efeito, também se verificava o contrário, ou seja, casos de assassinatos dos escravos pelos seus senhores. Neste aspecto, o Barão de Itapemirim destacou a ocorrência de outro homicídio no distrito de Itabapoana, quando "Maria Francisca do Espírito Santo e Maria Luiza do Sacramento mandaram amarrar uma escrava e a

\footnotetext{
${ }^{132}$ Relatório do Presidente da Província José F. da Costa Pereira Júnior, de 23/05/1861. Biblioteca Digital do APEES.

${ }^{133}$ ALMADA, Vilma, op. cit., 1984, p. 134. A historiografia mais recente sobre a escravidão no Brasil já eliminou o conceito de 'obediência ilimitada' do escravo ao seu senhor. Depois do trabalho de Almada, muitos outros foram realizados abrindo novas perspectivas de abordagem do tema, a exemplo das pesquisas de Sílvia H. Lara e João José Reis dentre outros mais recentes que vêem 'brechas' da legislação para escravos.

${ }^{34}$ Relatório do Presidente da Província Pedro Leão Velloso, de 25/5/1859, p. 12. Biblioteca Digital do APEES.
} 
maltratarão com pancadas e fogo de modo que a vítima teve de sucumbir. As rés achamse presas e procede-se contra elas na forma da lei”. ${ }^{135}$

Não obstante, a maioria dos registros encontrados nos relatórios presidenciais acerca desta matéria, diz respeito mesmo aos escravos que assassinaram os seus senhores. Esse tipo de ocorrência criminal permanecerá no decorrer do período, a exemplo dos casos apontados pelos presidentes da província para a década de 1870:

Foi cometido um assassinato no dia 10 de setembro de 1876, no lugar denominado Rio Novo, município do Cachoeiro de Itapemirim, na pessoa do fazendeiro Victorino Ferreira Leitão, por três escravos que a pouco a infeliz vitima havia comprado no Rio de Janeiro, os quais já responderam ao Júri e foram condenados a pena última. ${ }^{136}$

Dentre os escravos que assassinaram seus senhores na província capixaba e que, portanto, foram presos, submetidos a julgamentos e condenados, há o registro do crime praticado em São Mateus no ano de $1875^{137}$, quando “... foi assassinado com um tiro de bala, na estrada do sertão da cidade de S. Matheus, nas imediações da fazenda, o infeliz José Vicente de Leiria, cujo crime apurado pela Promotoria Publica foi praticado pelo próprio escravo do morto de nome Ignácio, que já se encontra preso". Embora não dispondo de informações sobre o desfecho desse caso, podemos deduzir que os castigos aplicados ao escravo foram extremamente severos, provavelmente desembocando em pena de morte para o mesmo, considerando que a Lei de 10 de junho de 1835 , que impunha a pena de morte ao escravo que matasse o seu senhor, com pequenas alterações, era ainda vigente na década de 1870 .

Nos idos de 1880, essas situações ainda são destacadas pelas autoridades provinciais, já que em 1883, o Chefe de Polícia notifica o assassinato, em Itabapoana, do Capitão Antonio Gomes da Silveira e Souza, e que, nesta mesma ocasião, foi ferido gravemente o seu irmão Manoel, pelos escravos Dyonisio e Clemente. Destaca ainda que um desses escravos suicidou-se quando perseguido pela polícia e que o outro, ao ser conduzido à Vila, precipitou-se no rio e só depois é que encontraram o seu cadáver. ${ }^{138}$

\footnotetext{
${ }^{135}$ Relatório do Vice-Presidente da Província Barão de Itapemirim, de 8/3/1856, p. 4; e, Relatório deste mesmo Vice-Presidente, de 25/5/1857, p.11 e 12. Biblioteca Digital do APEES.

${ }^{136}$ Relatório do Presidente da Província Antonio J. M. Nogueira da Gama, de 3/3/1877, p. 3. Biblioteca Digital do APEES.

${ }^{137}$ Relatório do Vice-Presidente da Província Manoel C. R. Mascarenhas, de 4/5/1875, p. 2. Biblioteca Digital do APEES.

${ }^{138}$ Relatório do Presidente da Província Martim F. R. de Andrada Jr., de 3/3/1883, p. 8. Biblioteca Digital do APEES.
} 
Diante dessas várias informações, deduzimos que era significativa a incidência de atos considerados criminosos praticados pelos escravos à época, o que traz à tona a existência de outras formas de resistência e rebeldia nos quadros da escravidão na província capixaba. No contexto da sociedade escravista, a violência, a dominação e a repressão foram mecanismos indispensáveis à manutenção do sistema, sendo a priori sancionados pela própria Justiça, pois,

\begin{abstract}
os abusos do poder levavam os senhores a punirem com excessivo rigor as menores faltas praticadas pelos escravos, enquanto que, por sua vez, a Lei, por negligência ou incapacidade, tacitamente sancionava essa ordem social violenta, levada pela convicção do perigo que representava para a sociedade punir o senhor pelos castigos impostos aos seus escravos. Dessa forma, a escravidão fechada em si mesma, caracteriza um sistema: violento, porque instável e inseguro; instável e inseguro porque violento. Neste círculo vicioso giravam presos os senhores e os escravos. ${ }^{139}$
\end{abstract}

O conjunto de dados e fragmentos selecionados nessas fontes oficiais nos informa também sobre outros aspectos relacionados ao tema em foco, tais como consta nos quadros fornecidos pelas autoridades policiais da província à época, ao tratarem da situação das cadeias existentes no Espírito Santo, do número de presos em cada uma delas, dos tipos de crimes praticados pelos mesmos, além das ocorrências policiais relativas aos delitos, suicídios e fatos similares verificados nos respectivos períodos.

No que se refere à quantidade dos escravos incluídos no número total de presos e detentos registrados nas principais cadeias da província e em distintos períodos, constatamos serem tais números bastante expressivos no leque dos dados recolhidos em diversas fontes consultadas para este fim. Neste sentido, no levantamento realizado em 1854, num total de 90 presos recolhidos na cadeia da vila de Itapemirim, havia "onze escravos, fugidos alguns, e outros por serem encontrados depois do toque de silencio à noite”. ${ }^{140}$ Ainda acerca disto, no início da década de 1860, consta que dentre 73 réus julgados pelo júri, 7 eram escravos e, dentre 23 réus julgados pelas autoridades policiais, 4 também eram escravos. No ano seguinte, nota-se que dentre os 52 réus julgados na província, 7 eram escravos. Neste período, o governo assume uma postura discriminatória em relação à presença de escravos no conjunto dos presos detidos nessas

\footnotetext{
139 ALMADA, Vilma Paraíso Ferreira de. Escravismo e Transição: o Espírito Santo (1850-1888). RJ: Edições Graal, 1984, p. 138.

${ }^{140}$ Relatório do Presidente da Província Sebastião Machado Nunes, de 25/5/1855, p. 4-5. Biblioteca Digital do APEES.
} 
cadeias, ao realçar a necessidade das prisões terem maior número de celas, onde "sejam presos os simples indiciados, cujos antecedentes e condição social não comportem a companhia de escravos ou de delinqüentes reconhecidamente perversos ". ${ }^{141}$

O Presidente Pindahiba ${ }^{142}$ ressalta que o Espírito Santo é uma das províncias mais pacíficas e ordeiras do Império e, com base nas estatísticas criminais, observa que o índice de crimes diminuiu na região. Segundo ele, dentre os 43 criminosos presos no ano de 1863, houve dois casos de "furtos de escravos", citando ainda - no item intitulado "fatos notáveis" - o caso de um escravo, de propriedade de João Pinto dos Santos, que praticou crime de estupro numa criançinha e fugiu, sem que a escolta que o perseguiu pudesse capturá-lo. Contudo, conforme relata o presidente, seu cadáver apareceu boiando no "Lamerão" próximo à Vitória, presumindo-se que o mesmo se atirou ao mar e morreu afogado. Nos idos de 1860, fatos desta natureza também são registrados pelo governo provincial ${ }^{143}$, dentre os quais se destaca um escravo fugido dentre os 34 presos da cadeia de Vitória e também que outro escravo fugido foi encontrado morto na praia no entorno da capital, cujo motivo foi asfixia por submersão.

Mesmo não dispondo de muitas informações acerca de suicídios de escravos na província capixaba nas fontes consultadas, consideramos importante ressaltar que esta é uma questão ainda pouco explorada pela historiografia dedicada à escravidão no país, mesmo sabendo-se da significativa incidência de suicídios entre os mesmos no Brasil escravista. No entanto, podemos identificar certos aspectos da questão levantados em estudos sobre o tema, mas abarcando outras províncias brasileiras no Oitocentos, os quais fornecem informações e dados quantitativos coletados em vários tipos de fontes, cujos resultados, em seu conjunto, contribuem na elucidação deste assunto também no contexto da província capixaba. ${ }^{144}$

\footnotetext{
${ }^{141}$ Relatório do Presidente da Província José F. da Costa Pereira, de 23/5/1862, p.10, 11,19. Biblioteca Digital do APEES.

${ }^{142}$ Relatório do Presidente da Província Eduardo Pindahiba de Mattos, 3/10/1864, p.12-15. Biblioteca Digital do APEES.

${ }^{143}$ Relatório do Presidente da Província Carlos de C. Pinto, 23/5/1867, Anexo 1, p. 4-5. Biblioteca Digital do APEES.

${ }^{144}$ Cf., dentre outros estudos: OLIVEIRA, Saulo Veiga \& ODA, Ana Maria G. Raimundo. O suicídio de escravos em São Paulo nas últimas décadas da escravidão - artigo disponível na biblioteca on-line SciELO (Bireme/FAPESP), comentário postado por InovaBrasil às 8/20/2008 06:39 AM (Fonte: Alex Sander Alcântara / Agência FAPESP); ODA, Ana Maria G. Raimundo \& OLIVEIRA, Saulo Veiga. Registro de suicídios entre escravos em São Paulo e na Bahia (1847-1888): notas de pesquisa ("Dos desgostos provenientes do cativeiro: uma história da psicopatologia dos escravos brasileiros no século XIX" / FAPESP); REYNALDO, Renata. Representação do suicídio de escravos no Recife acompanhou mudanças sociais - Resenha da dissertação de Ezequiel David do A. Canário/UFPE, disponível em http://www.ufpe.br/agencia/index.php?option=com_content\&view=article\&id, acesso em 26/08/2011.
} 
Nesta perspectiva, a ocorrência de suicídios entre escravos mostra que, na medida em que a escravidão era, pelo menos no plano da retórica, questionada e vista como um elemento de atraso, o suicídio de escravos ganhava novos sentidos, e tornava-se uma prova dos efeitos degeneradores da escravidão na sociedade. Nota-se ainda que as abordagens referentes aos "suicídios de escravos" acompanharam as mudanças sociais e serviram como instrumento de crítica ao sistema escravista, haja vista que este assunto não era tratado da mesma forma, recebendo ênfases distintas conforme fossem os diferentes interesses dos grupos integrantes da sociedade à época.

De acordo com estudos mais recentes sobre o tema ${ }^{145}$, não se deve generalizar a explicação das causas dos suicídios entre escravos, pois existe um amplo leque de possibilidades que poderiam levar o escravo a tomar uma atitude tão radical em relação a sua vida. Portanto, observa-se que a prática do suicídio entre escravos envolvia motivações de natureza diversa, como as psicossomáticas, o desejo de retornar ao seio dos amigos e familiares na África, a fuga do cativeiro, o medo de castigos severos, entre outras, que nos remetem à reflexão acerca do desgaste físico e emocional sofrido pelos indivíduos submetidos ao cativeiro.

Sendo assim, ocorriam suicídios em momentos de fuga e/ou para evitar a venda a outro senhor, pelo temor de castigos 'imoderados', além do banzo e da chamada alienação mental do escravo. Acerca desta última causa tão alegada nos documentos oficiais, ressalta-se que nesses tipos de fontes, os motivos apresentados para justificar o suicídio dos escravos passavam por "filtros sociais", podendo, sobretudo nos casos da “alienação mental", estar-se encobrindo situações de assassinatos e mortes de escravos por excessos de castigos físicos aplicados pelos senhores, evitando-se, desta forma, maiores investigações acerca do trágico ocorrido.

Muito também já se mencionou acerca do banzo enquanto causa dos suicídios entre escravos, cuja recorrência revela facetas ainda pouco conhecidas da escravidão, sendo notável atribuir-se ao banzo uma forte causa desses suicídios. No século XIX, com as primeiras teorias psicológicas, o comportamento dos escravos "banzeiros" foi reconhecido como distúrbio mental associado à nostalgia, sendo o mesmo considerado responsável pela espantosa mortandade notada entre os africanos, principalmente nos recém-chegados ao Brasil, bem como pelo número de suicídios ocorridos entre eles.

\footnotetext{
${ }^{145}$ Cf. pesquisas e estudos referidos na nota anterior (Nota $\mathrm{n}^{\circ} 142$ ).
} 
Provavelmente, os rótulos atribuídos ao banzo encobriam uma vasta gama de problemas psicológicos ou psiquiátricos “que iam da depressão à esquizofrenia; ou eram provocados pela desnutrição, por doenças contagiosas, ou por consumo excessivo de álcool e drogas - como a maconha, apreciada por muitos escravos, que a chamavam de pango". Porém, que não se deve reduzir a importância do banzo enquanto uma das expressões trágicas da loucura comum a milhões de indivíduos vitimados pelo tráfico de escravos, e que a divulgação desse sofrimento nos jornais pode ter contribuído na formação da sensibilidade abolicionista no interior da sociedade imperial. ${ }^{146}$

Nota-se, grosso modo, que o índice de "mortes voluntárias" entre escravos, quando comparadas ao dos homens livres, era de duas ou três vezes mais elevado, cujas variações vinculavam-se aos quantitativos de livres e escravos no quadro demográfico das regiões pesquisadas e também ao período enfocado. Nesta perspectiva, o estudo deste tema com referência às duas últimas décadas da escravidão em São Paulo, aponta para um alto índice de suicídios entre escravos naquela província, onde, em 75 casos de suicídios de escravos, 48 foram em Campinas e 19 em outras cidades ${ }^{147}$.

Ainda acerca desta questão, deve-se levar em conta que na segunda metade do século XIX a mão de obra escrava sofreu grandes abalos em decorrência da proibição do tráfico (1850), da intensificação do tráfico interprovincial (sobretudo do Nordeste para o Sudeste do país), da decretação da Lei do Ventre Livre (1871), dentre outros, cujas situações provocaram uma nova configuração no perfil e na distribuição do contingente escravo nas regiões brasileiras. Nesta perspectiva, no estudo já citado acerca do suicídio de escravos em Recife (1850-1888) constatou-se que, dentre os 188 casos de suicídios ocorridos naquela localidade no período, 80 foram de escravos e 8 de libertos - demonstrando que, mesmo numa conjuntura de diminuição da população escrava e aumento da população livre, a razão de 10 suicídios de livres para 8 de cativos é relativamente alta para um contingente de cativos que a cada dia diminuía em Recife.

\footnotetext{
${ }^{146}$ Cf. VENANCIO, Renato Pinto. Banzo: a melancolia negra. Aventuras na História 3, 01/02/2005 disponível em http://guiadoestudante.abril.com.br/estudar/historia/banzo-melancolia-negra-434032.sh, acesso em 26/08/2011 - Segundo este autor, ainda hoje se discute o significado de banzo, sendo mais aceito o que se remete à origem africana da palavra, equivalente a "pensar" ou "meditar". Não obstante, o termo banzo também foi utilizado, em 1799, para designar uma doença integrante do leque das "doenças agudas e crônicas que mais freqüentemente acometem os pretos recém-tirados da África", em cuja situação o escravo permanecia entristecido, parava de falar e, acima de tudo, deixava de se alimentar, vindo a falecer pouco tempo depois.

${ }^{147}$ Campinas era conhecida na época como "Bastilha Negra", possuindo uma população constituída por 18 mil livres e 14 mil escravos, sendo que esses últimos representavam $44 \%$ do total desta população. (Cf. ODA \& OLIVEIRA, op. cit., 2008).
} 
Outra questão que se destaca neste sentido, diz respeito à representação dos suicídios entre pessoas livres por um lado e dos suicídios entre escravos por outro, na medida em que as pesquisas revelam uma distinção entre essas duas situações, conforme análises do conteúdo dos jornais à época, nos quais o suicídio entre livres e escravos foi representado de forma diferenciada, ou seja, que as notícias veiculadas sobre as mortes voluntárias variavam de acordo com o status do suicida. ${ }^{148}$

Sendo assim, os suicídios de pessoas livres eram explicados com base nos aspectos relacionados a problemas financeiros, questão passional, doenças, falta de fé cristã, dentre outras. Nas situações de mortes voluntárias entre livres, os "pormenores do caso eram citados, os motivos do ato eram indagados e comentados, além da presença de frases de pesar pela morte do indivíduo e condolências à família". ${ }^{149}$

Em contrapartida, as notícias envolvendo mortes voluntárias entre escravos, além de serem mencionados de forma objetiva e pontual - constando apenas o nome do senhor e do escravo, se este era foragido, o local e o meio escolhido para o ato -, estas não tinham a preocupação de esclarecer os motivos do suicídio, denotando cuidados em eximir o senhor do cativo suicida de qualquer responsabilidade sobre a decisão do mesmo em dar cabo à vida. Geralmente, enquadravam-se tais ocorrências no rol da loucura ou desespero, ou por motivos ignorados (tanto pelo senhor quanto pelas pessoas próximas ao escravo em questão e que foram inquiridas pela polícia). Em certos casos, os suicídios de escravos eram atribuídos como conseqüência dos vícios, do caráter bravio, indisciplinado e rancoroso do escravo, ou até mesmo relacionados à origem étnica do cativo. Ou seja, nas conjunturas em que a legitimidade da escravidão não era ainda questionada pelas elites, o suicídio entre escravos esteve relacionado mais ao cativo do que ao cativeiro.

Acerca dos meios mais usuais nos atos suicidas de escravos, nota-se que dentre estes predominava o enforcamento, seguido de afogamento e uso de arma branca, sendo raros os casos de envenenamento. Muitas dessas situações se aplicam em relação ao "suicídio" de escravos na província capixaba, pois, no relatório do Chefe de Polícia em 1868 encontramos as seguintes citações envolvendo mortes e suicídios de escravos: a do escravo José (propriedade de João Chrisostomo de Carvalho), marinheiro da lancha Santo Antonio, que se atirou ao mar e afogou-se (a tripulação e o mestre da referida

\footnotetext{
${ }^{148}$ Cf. pesquisas e estudos referidos em nota anterior (Nota $\mathrm{n}^{\mathrm{o}} 142$ ).

${ }^{149}$ Cf. ODA \& OLIVEIRA, op. cit., 2008.
} 
lancha declararam que o escravo foi acometido por um "ataque de alienação mental" que o levou à morte); a do escravo Vicente (propriedade de Manoel dos Santos Simões) que viajando numa canoa no rio sitio Furado em Nova Almeida, caiu da canoa e afogouse; e a de outro escravo de nome Vicente (pertencente ao americano J. A. Roussel estabelecido nas matas do rio Doce) que foi encontrado enforcado com um cipó na referida mata, sendo que o mesmo havia desaparecido há pelo menos cinco dias. ${ }^{150}$

No referido Relatório da Polícia do ano de 1868, identificamos também o Quadro $n^{o} 3$ (Relação dos presos recolhidos à cadeia pública da capital durante o ano de 1867$)^{151}$, onde consta que no conjunto de 224 presos, 55 eram escravos $(24,5 \%$ do total), cujos crimes assinalados para os mesmos foram: "Requisição de seu Senhor" (26 casos), "Fugido" e/ou "Por andar fugido" (10 casos), "Desordem" (5 casos), "Ferimento" (1 caso), "Embriaguez" (4 casos), "Andar fora d'horas" (1 caso), "Pronunc. " (sic)" (2 casos), e nada consta (6 casos). Pouco tempo depois, nota-se que num total de 158 criminosos recolhidos pela polícia em 1869, 130 foram "por embriaguez, desordem e outras culpas semelhantes", em cujas categorias "estão incluídos muitos escravos que foram presos à requisição dos respectivos senhores".

Nesta perspectiva, ao analisarmos o conteúdo expresso nas Posturas Municipais de São Mateus e da Vila da Barra de São Mateus no período em foco, colocaremos em destaque as diversas normas referentes às proibições e punições direcionadas especificamente ao comportamento dos escravos naquelas duas localidades, conforme a abordagem do item que se segue.

\footnotetext{
${ }^{150}$ Anexo $G$ do Relatório do Presidente da Província Francisco L. B. Sampaio, Abril/1868. Biblioteca Digital do APEES.

${ }^{151}$ Cf. Anexo $G$ do Relatório do Presidente da Província Francisco L. B. Sampaio, Abril/1868. Biblioteca Digital do APEES.
} 


\subsection{A Legislação Provincial e as Posturas Municipais.}

Além das diversas referências feitas à Legislação Provincial nos tópicos tratados anteriormente, consideramos oportuno focalizar também outros aspectos que perpassam a relação que se estabelece entre a manutenção do sistema escravista e o conjunto das leis decretadas e aplicadas no âmbito provincial e municipal. Nesta perspectiva, trataremos inicialmente das Posturas Municipais vigentes na cidade de São Mateus e na Vila da Barra de São Mateus para, em seguida, procedermos à análise de outros temas recorrentes no conjunto da Legislação Provincial, sobretudo no que tange às medidas inerentes a criação e aplicação dos Fundos destinados à emancipação dos escravos no Espírito Santo, procurando destacar as suas especificidades em meio ao processo mais geral desencadeado pelo governo imperial nesta matéria.

As Posturas Municipais e os mecanismos locais de controle social da escravidão: a discriminação e o cotidiano do escravo.

Ao analisarmos o conteúdo expresso nas Posturas Municipais das localidades capixabas do período, identificamos diversos itens que se referem a proibições e punições específicas ao comportamento dos escravos. Estes itens, ou melhor, estes 'artigos', foram elaborados pela Câmara Municipal e fazem parte de um conjunto maior de normas e regras de conduta inerentes aos diversos interesses da municipalidade. Para os objetivos específicos deste estudo, selecionamos os assuntos relativos à escravidão e aos escravos, seus comportamentos e costumes, os quais configuram um quadro parcial da sociabilidade da população, principalmente no transcurso das décadas de 1860, 1870 e 1880, período em que se registra a aprovação de um grande número dessas Posturas.

Conforme a circunstância e a mudança de costumes, a Câmara enviava artigos para serem aprovados e inseridos no Código de Posturas. Contudo as 'posturas' eram, às vezes, inconsistentes, obscuras e sem adequação à realidade local, apesar de terem por objeto a codificação de normas reguladoras da organização social da população em seus usos e costumes. As Posturas também se caracterizavam pelo aspecto facultativo das suas determinações, sendo que, em alguns artigos subsequientes àqueles que impunham proibições, geralmente havia ressalvas, haja vista a impraticabilidade de serem 
atendidas. Contudo, para as punições e proibições relacionadas aos escravos não encontramos nenhuma ressalva.

Sendo assim, não é de se estranhar que a infração do Código de Posturas da Câmara Municipal figure em segundo lugar na relação dos maiores delitos praticado na Província do Espírito Santo a partir de 1859. Nota-se também, em certos casos, o registro de queixas dos cidadãos diretamente ao governo provincial, quando consideravam abusivas as regras estabelecidas nas Posturas.

Em 1861, o Decreto n ${ }^{\circ} .407$ - item 442 aprovou as Posturas da Câmara Municipal da Barra de São Mateus, sendo largamente estendidos os artigos referentes aos escravos, seja porque, até então, não haviam recebido a atenção considerada necessária, seja porque os perigos existentes naquele grupo tornaram-se mais evidentes. Entre os artigos, podemos destacar alguns que se referem especificamente a proibições e punições, tais como: Artigo 8 - que pune "o taberneiro que consentir em sua taberna escravo mais tempo que o necessário para compra dos gêneros que vai buscar, e se este for encontrado bebendo, ou jogando, será multado em $30 \$$ rs., ou oito dias de cadeia"; Artigo 38 - estipulando que a pessoa que "proferir em lugar publico palavras obscenas, fazer gestos ou tomar atitudes da mesma natureza, ou apresentar quadros ou figuras ofensivas da moral pública, multa de $40 \$$ rs. e, sendo escravo, será punido com oito dias de prisão"; Artigo 41 - em que "o escravo achado em ato de infração poderá ser logo conduzido ao subdelegado de polícia, e recolhido à cadeia até verificar-se quem é seu senhor para contra ele requerer-se a imposição da pena".

Em outra Postura Municipal de São Mateus, de 06/12/1864, Lei nº. 480, item 548, constam as seguintes normas e restrições: Artigo 10 - "ninguém poderá comprar a escravos café ou qualquer outro gênero de produção agrícola, assim como animais de qualquer espécie, sem autorização por escrito dos senhores ou administradores dos mesmos; os infratores serão multados em trinta mil réis, e no dobro na reincidência"; Artigo 14 - fica estabelecido que "as pessoas que arrematarem ou forem encarregadas das passagens, não passarão escravos, sem que estes mostrem bilhetes de seu senhor ou administrador, no qual lhes dê consentimento: se assim não procederem, incorrerão na multa de cinco mil réis."

Na década de 1870 encontramos uma nova aprovação do Código de Posturas da Câmara Municipal de São Mateus ${ }^{152}$, tornando o controle sobre o escravo mais

${ }^{152}$ Cf. Ementário das Leis Provinciais, Catálogo do APEES - Lei no . 06, item 1115, de 11/11/1879. 
minucioso, abrangendo questões relacionadas a divertimentos, segurança pública dentre outras, tais como: Artigo 45 - "Os escravos que forem encontrados a jogar quaisquer jogos sofrerão cinco dias de prisão e as pessoas livres que com eles jogarem, ou prestarem para isso suas casas sofrerão vinte mil réis de multa"; Artigo 78 - "A pessoa que der couto a escravos fugidos, aconselhá-los a fugir, seduzi-los para qualquer fim pagará trinta mil réis de multa por cada escravo e dez dias de prisão, além de pagar os dias de trabalho aos donos dos mesmos"; Artigo 79 - "Os escravos que sem bilhetes de seus senhores ou pessoas deles encarregados, forem encontrados nas ruas, depois do toque de recolher, serão presos até o dia seguinte"; Artigo 81 - "Ficam expressamente proibidas as reuniões de escravos nas casas de negócio, multa de dez mil réis aos donos destas casas".

Portanto, conforme podemos notar no teor dos artigos constantes nas referidas Posturas Municipais das duas localidades mencionadas, o escravo era tolhido em vários aspectos da sua vida cotidiana e também no convívio social, cuja situação fica explícita tanto na cidade de São Mateus como também na Vila da Barra de São Mateus. Isto é perceptível nas diversas proibições abarcando a sociabilidade, os costumes e os comportamentos dos escravos nessas duas edilidades, cujo reforço a tais normas também atingiam determinados indivíduos livres dessas sociedades, a exemplo dos donos de tabernas e proprietários de barcos, dentre outros.

As Leis Provinciais e o Fundo de Emancipação.

Na Legislação Provincial do Espírito Santo e nos relatórios presidenciais, sobretudo na década de 1870 , notamos que outro tema importante referente à escravidão passa a fazer parte das preocupações governamentais: trata-se da decretação da chamada Lei do Ventre Livre (Lei Rio Branco), sua regulamentação e a concomitante criação do Fundo de Emancipação de escravos, cujas disposições acerca deste último encontramse discriminadas no texto da referida lei. Contudo, antes de focarmos este processo e os seus efeitos no contexto específico da província capixaba, destacaremos as linhas gerais que presidiram a tramitação desta matéria pelo governo imperial, já que os encaminhamentos de cunho mais geral e referente a esta legislação específica deveriam ser acatados em todas as províncias do Brasil. 
O Fundo de Emancipação de Escravos do Império é considerado um instrumento libertador implantado através da Lei 2.040, de 28 de setembro de 1871, apelidada de Lei do Ventre Livre. No conjunto das medidas legislativas adotadas pelo governo imperial em relação à situação da escravidão no país, a referida legislação demarca o momento crucial em que o Estado assumiu a condução do processo de emancipação escrava, posto que, no texto que regulamenta esta lei, fica explícita a intenção do governo em extinguir a escravidão ainda que de forma gradual, no sentido de garantir uma transição segura para uma mudança abrupta e que abalaria as bases da sociedade imperial.

Muitos estudos já se ocuparam de analisar os meandros dos processos que presidiram as calorosas discussões em torno da aprovação e da execução da Lei do Ventre Livre à época, já que a mesma, além de declarar livres os filhos das escravas nascidos a partir daquela data, também instituiu, em seu $3^{\circ}$ artigo, a criação do Fundo de Emancipação de Escravos no Império do Brasil, cujo instrumento e as brechas abertas pela lei de 1871, foram aproveitados pelos escravos "que, nos anos seguintes, com a conivência de advogados emancipacionistas, usaram cada vez mais a instância da Justiça para procurar alforriar-se" (PENA, 2001:18). ${ }^{153}$ Em outras palavras, o referido Fundo tornou-se um fator que contribuiu na condução do processo emancipacionista em curso, sendo utilizado como estratégia da luta escrava para se livrar do cativeiro.

Neste sentido, na ocasião de aprovação da Lei Rio Branco, a maior resistência imposta ao projeto de lei veio dos representantes escravocratas das províncias cafeeiras da região centro-sul. ${ }^{154}$ Mesmo assim, o projeto foi transformado em Lei, onde se estabelecia a criação do Fundo de Emancipação, cuja finalidade era registrar cativos de todas as províncias do Brasil, a fim de serem beneficiados pelas quotas do Fundo, com base nos recursos financeiros provenientes dos impostos sobre escravos, de loterias nacionais, de multas e outras contribuições.

Uma caracterização geral da aplicação e atuação do Fundo de Emancipação é objeto de destaque no estudo realizado por Fabiano Dauwe ${ }^{155}$, segundo o qual este

\footnotetext{
${ }^{153}$ A título de exemplo, e sem desmerecer o conjunto dos valiosos trabalhos dedicados a tais questões, podemos citar, particularmente, uma obra de grande relevo e que trata de forma detalhada deste assunto, a saber: PENA, Eduardo Spiller. Pajens da Casa Imperial, jurisconsultos, escravidão e a lei de 1871. Campinas, SP: Editora da Unicamp / Centro de Pesquisa em História Social da Cultura, 2001.

${ }^{154}$ Acerca disto, Vilma Almada destaca que os dois deputados pela Província do Espírito Santo votaram contra o projeto.

${ }^{155}$ Cf. DAUWE, Fabiano. A libertação gradual e a saída viável: os múltiplos sentidos da liberdade pelo fundo de emancipação de escravos. Dissertação de Mestrado/UFF, 2004 - Apud SANTOS, Lucimar Felisberto dos. Os bastidores da lei: estratégias escravas e o Fundo de Emancipação. In: Revista de
} 
Fundo reuniria recursos pecuniários a serem destinados a cada província do país (e também ao Município Neutro) para a libertação da quantidade de escravos que fosse possível, sendo que, as cotas a serem distribuídas entre as províncias deveriam ser proporcionais ao número de escravos existentes nas mesmas.

Todavia, antes se dar início à concessão das cartas de liberdade com os recursos provenientes deste Fundo, dever-se-ia providenciar a Matrícula Geral (Especial) dos Escravos em todo território nacional, em cuja matrícula deveria constar nome, sexo, cor, idade, estado civil, filiação, aptidão para o trabalho e a profissão do escravo. ${ }^{156}$

Neste sentido, em cada uma das províncias do Império foi estabelecida uma Junta Classificatória de Escravos com a atribuição de elaborar listas ou relações dos escravos a serem contemplados com os recursos oriundos do Fundo de Emancipação. As Juntas Classificatórias de Escravos, ao elaborar as referidas listas/relações de escravos, deveriam atentar para os critérios de classificação e/ou exclusão dos escravos no tocante aos benefícios concedidos pelo Fundo. ${ }^{157}$

Sendo assim, nos critérios estipulados para a inclusão/classificação dos escravos nestas listas, predominava a preferência pela emancipação da família escrava, objetivando mantê-la unida ou ainda possibilitar que isto se efetivasse, sobretudo no caso de cônjuges com filhos, mas que viviam separados por serem escravos de senhores diferentes, dentre outras situações em que a família escrava deveria ser priorizada na composição das referidas listas. Esta classificação também contemplava a emancipação individual de escravos, cujos critérios eram diferenciados daqueles aplicados à família escrava. No caso dos "indivíduos" cativos, teriam prioridade os que tivessem filhos livres, os que estivessem na faixa etária entre 12 a 50 anos (preferencialmente as mulheres mais jovens e os homens mais idosos), os que pudessem entrar com certa quota para a sua libertação, além dos mais morigerados a juízo dos senhores, sendo que, em igualdade de condições a sorte decidirá. ${ }^{158}$

Acerca da exclusão dos escravos em tais listas, deveriam ser observados os seguintes critérios: os escravos sujeitos a cláusula de serviço e às alforrias condicionais,

História, 1, 2 (2009), pp. 18-39 - artigo disponível em www.revistahistoria.ufba.br/2009..2/a02.pdf, acesso em 30 de julho de 2011.

${ }^{156}$ Cf. Decreto 4.835, de 1 de dezembro de 1871, criado para regulamentar os critérios a serem utilizados na Matrícula Especial de Escravos, instituída na Lei 2.040, de 28 de setembro de 1871.

${ }^{157}$ Tais critérios foram especificados no Artigo 27 do Decreto $n^{\circ} 5.135$, de 13 de novembro de 1872, que aprovou a regulamentação geral para a execução da Lei 2.040.

${ }^{158}$ Cf. Decreto de no 5.135, já referido na nota 137. 
os suspeitos de crimes, os fugitivos ou habituados à embriaguez, os que estivessem tentando obter a liberdade judicialmente, dentre outros critérios de exclusão.

Esses critérios de classificação dos escravos vigoraram por mais de uma década, sofrendo alterações somente pelo aviso circular datado de 19 de janeiro de 1883, que estendia as preferências de classificação também aos escravos casados com pessoas livres. Todavia, este critério já era observado na Corte desde a primeira listagem concluída pela Junta em $1876 .^{159}$

Também no caso da aplicação prática das quotas deste Fundo houve grande resistência dos fazendeiros escravocratas das áreas cafeeiras do país, a exemplo dos valores exorbitantes que estes impuseram ao preço dos seus escravos, daqueles que possuíam as características exigidas pelo referido Fundo para serem alforriados, além do retardamento, por vários anos e em vários locais, do início dessas emancipações. Nesta situação, registra-se que de maio/1876 a agosto/1885, após a aplicação do Fundo de Emancipação, numa população escrava de 1.333 .228 pessoas, apenas 2,1\% foram libertadas com o mesmo - ou seja, 24.165 indivíduos cativos.

Na Província do Espírito Santo, o Fundo libertou 422 escravos, numa população escrava estimada em 19.762 pessoas no ano de 1885, ou seja, abrangendo apenas $2,1 \%$ do contingente escravo existente na província à época. Acerca disto, Almada (1984:192) observa que esta média ainda foi a maior entre as demais províncias cafeeiras do sudeste brasileiro $(\mathrm{MG}=1,6 \% ; \mathrm{RJ}=1,5 \%$ e $\mathrm{SP}=0,6 \%)$.

Portanto, para certos autores fica patente que o Fundo de Emancipação não apresentou resultados notáveis, tornando-se, muitas vezes, "um meio dos proprietários se livrarem de seus escravos 'menos úteis' a preços muito satisfatórios”, haja vista que "mais escravos foram libertados gratuita ou condicionalmente, do que pelo Fundo de Emancipação". ${ }^{160}$

Mesmo antes da aprovação da Lei do Ventre Livre, os rumos tomados pelo movimento emancipacionista em direção à abolição 'gradual' da escravatura no Brasil, ganhou forma em vários pontos do Império, sendo que no Espírito Santo, seus reflexos se fizeram sentir na Lei Provincial $\mathrm{n}^{\mathrm{o}} 25$, de 4 de dezembro de 1869, a qual autorizava a despesa anual de 6:000\$000 réis para alforrias de escravos de cinco a dez anos de idade, cujos benefícios deveriam ser requeridos junto ao governo até sete de setembro de cada

\footnotetext{
${ }^{159}$ Cf. SANTOS, op. cit., p. 20.

${ }^{160}$ CONRAD, apud ALMADA, 1984, p. 192 e 193.
} 
ano. Assim, ao final do primeiro ano de validação desta lei (07/09/1869 a 07/09/1870), foram apresentadas 15 petições e beneficiadas 11 escravas: 3 em Vitória; 4 em Guarapari, 1 na Serra, 1 na Vila do Espírito Santo, 1 em Cariacica e 1 em Mangarahy. Nesta distribuição dos referidos benefícios, nota-se que nenhuma alforria foi requerida para São Mateus e Itapemirim, considerados locais de expressiva concentração de escravos na província. ${ }^{161}$

Entretanto, em 1871, a já citada lei é objeto de análise crítica no discurso do presidente da Província do Espírito Santo, Ferreira Correa ${ }^{162}$, ao destacar que a mesma, embora representasse recompensa financeira imediata para o senhor, só futuramente, talvez, viesse a constituir-se em benefício para a escrava, haja vista a tenra idade que contemplava as alforrias (5 a 10 anos), pois, nessa situação, a escrava alforriada continuaria vivendo na casa do seu ex-senhor, que depois de receber o preço da alforria, a manteria consigo na mesma condição de escrava e, conseqüentemente utilizando-se dos seus serviços como outrora. Considerava-se mais apropriada a idade de 15 a 30 anos para a concessão destas alforrias, pois, nesta faixa etária, a alforriada já não precisaria mais viver sob a tutela de do seu ex-senhor.

Acerca disto, nota-se que foi aprovada pela Assembléia Legislativa do Espírito Santo a Lei Provincial n ${ }^{\circ}$. 30, de 11 de dezembro de 1871, a qual consignou a quantia de 6:000\$000 réis anuais para a manumissão de escravos do sexo feminino de 12 a 35 anos, por preço não excedente a um conto de réis cada uma, "dando-se preferência àquelas que tiveram pecúlio". Também esta lei provincial de 1871 foi objeto de crítica por conceder a alforria em função da capacidade de pecúlio da escrava, evidenciando o pouco amadurecimento da sociedade capixaba para com a emancipação dos escravos.

$\mathrm{Na}$ finalização deste capítulo consideramos oportuno registrar a percepção que tivemos acerca do papel crucial da legislação enquanto um dos pilares básicos utilizados pelo governo na manutenção do sistema escravista no país, cujas leis referentes à abolição gradual da escravidão foram amplamente utilizadas pelas oligarquias dominantes no sentido de retardar ao máximo o fim da escravidão no Brasil.

Nos três tópicos tratados nesta parte do estudo a principal questão que orientou o conjunto das informações e argumentos reunidos em cada uma das temáticas enfocadas

\footnotetext{
${ }^{161}$ Cf. Almada, 1984, p.189 e 190.

162 Relatório do Presidente da Província do Espírito Santo Francisco Ferreira Correa, de 9/10/1871, p.132133, Biblioteca Digital do APEES.
} 
foi a de evidenciar a posição frágil e vulnerável do escravo no campo da legislação criada para amortecer os impactos que a abolição da escravatura causaria no país caso esta se configurasse numa ruptura repentina e radical da ordem escravocrata.

Mesmo os escravos conseguindo tirar certo proveito de determinadas conjunturas que marcaram a decretação das principais leis relativas à abolição gradual da escravidão no Brasil, tais como em 1850 com a proibição do tráfico, em 1871 com a Lei do Ventre Livre e também nos momentos finais da escravidão, o governo e as elites dominantes conseguiram reverter em seu favor a aplicação prática das referidas leis, tendo em vista a posição marginal e submissa do escravo nas hierarquias sociais predominantes no transcurso da segunda metade do século XIX.

Em tal contexto, aos escravos restou a possibilidade de criação de meios e alternativas que subvertessem as regras inerentes ao bom funcionamento do sistema escravista através das fugas, da formação dos quilombos, das revoltas, dos suicídios e das brechas que a legislação lhes proporcionou no sentido da obtenção da liberdade e da conquista da autonomia e concomitante afirmação da identidade, tão sufocada pela longa duração das áridas condições a que foram submetidos em cativeiro, cujas situações, conforme foi possível verificar no desenvolvimento do texto, mesmo apresentando certas particularidades locais e regionais, foram processadas de formas semelhantes tanto em São Mateus, como na Província do Espírito Santo e também no contexto da nação como um todo. 
CAPÍTULO 3

O ESCRAVO ENQUANTO MERCADORIA 
Ao longo de todo o século XIX, a farinha de mandioca foi o produto-rei da produção agrícola e da economia de São Mateus, já que a mesma permaneceu no topo das suas exportações durante todo esse período, mesmo com a gradual implantação da lavoura cafeeira naqueles territórios a partir de meados do Oitocentos.

Outras atividades também geravam riquezas em São Mateus a exemplo dos produtos oriundos do extrativismo vegetal, praticado em larga escala nas ricas matas e florestas daquela região desde o período colonial, onde se incluem a exploração das madeiras e das ervas medicinais (sendo que, neste último caso, a poaia teve mais destaque).

Contudo, não se pode ignorar que o comércio de escravos sempre foi dinâmico nesta realidade econômica, haja vista o grande número de compras e vendas de escravos registrados nos documentos cartoriais de São Mateus, além das diversas escrituras tratando de hipotecas e penhoras de escravos em circunstâncias variadas, cujas situações em conjunto movimentaram grandes quantias do capital circulante naquela praça/mercado, tornando São Mateus parte importante da economia provincial do Espírito Santo.

Uma tendência geral verificada no contexto escravista do Brasil a partir de 1850, com a proibição do tráfico externo de escravos, diz respeito ao fato de que muitos comerciantes e fazendeiros estimularam o comércio interno de escravos, tanto de algumas províncias para outras, como no interior das próprias províncias, podendo estas transações serem chamadas de 'tráfico interprovincial' ou 'intraprovincial' de escravos.

Observa-se que os estudos acerca desta temática, até pouco tempo atrás, trataram sobretudo das regiões agro-exportadoras, sendo que as regiões com economia mais voltada para o mercado interno eram quase que exclusivamente vistas como 'perdedoras' de escravos no interior destes circuitos. ${ }^{163}$

Também podemos perceber, no conjunto das escrituras públicas que envolvem negócios com escravos, que determinadas famílias/indivíduos comparecem nestes documentos num movimento ou dinâmica financeira 'decadente', ou seja, vendendo muitos escravos, penhorando ou hipotecando outros tantos, demonstrando uma

163 Tal foi o caso do Rio Grande do Sul que, entre 1863 e 1872 apresentou uma perda de aproximadamente dez mil escravos, quase mil por ano, mas que nas pesquisas recentes demonstram uma outra realidade em Pelotas, por exemplo. Cf. VARGAS, Jonas. Das charqueadas para os cafezais? $O$ comércio de escravos envolvendo as charqueadas de Pelotas (RS) entre as décadas de 1850 e 1880. Anais do $5^{\circ}$. Encontro Escravidão e Liberdade no Brasil Meridional, p.1. 
tendência de perda ou fragmentação de seus patrimônios (tais como escravos, imóveis etc), aparentando certo 'empobrecimento' na hierarquia sócio-econômica regional.

Por outro viés, outro grupo de famílias/indivíduos ${ }^{164}$ apresentam um movimento contrário, ou seja, de crescimento e aumento dos seus investimentos e patrimônios, comparecendo nestas escrituras como aqueles que dispõem até de capitais para bancar um grande número de empréstimos, penhora e hipotecas no conjunto desta sociedade mateense.

Neste contexto, se assiste à derrocada de algumas famílias, diante da ascensão de outras, mais bem preparadas para enfrentar os reveses econômicos que marcaram as conjunturas do período estudado.

Sendo assim, consideramos que a concentração da renda ajudou a condicionar quem vendeu e quem comprou escravos após a extinção do tráfico atlântico. Enfim, pode-se afirmar que as transações de escravos envolvendo a oligarquia mateense a partir de meados do Oitocentos, apenas aprofundou uma concentração de renda que já existia anteriormente.

O comércio de escravos figurou como mais um elemento na estrutura comercial que se montou em São Mateus ao longo dos anos. Este comércio "não gerou fortunas no século XIX naquela região, apenas fez parte delas, ou gerou possiblidades de outros investimentos quando as negociações revertiam em dinheiro." 165

Conforme a análise que fizemos dos dados reunidos na pesquisa envolvendo as transações, registradas em cartório, referentes ao comércio de escravos em São Mateus, percebemos que é possível identificar e destacar quem eram os comerciantes/ fazendeiros que mais se destacaram no comércio de escravos em São Mateus no período (1863-1887), sem descartar a possibilidade da ocorrência de negociações não registradas em cartório.

No caso das mulheres casadas, via de regra, tornavam-se proprietárias por ocasião da morte do marido, e várias destas viúvas aparecem participando do comércio de escravos em São Mateus, sobretudo para a venda de cativos.

\footnotetext{
${ }^{164}$ Não podemos deixar de considerar que a maioria dos negociantes analisados possuem algum grau de parentesco entre si.

165 A região de São Mateus, a nosso ver, apresenta uma certa similaridade com Mogi das Cruzes no interior paulista. Cf. CONSTANTE, Armando de Melo Servo. Comércio de escravos em Sant'Anna de Mogy das Cruzes na segunda metade do século XIX - 1864/1887. In: Anais do XVII Encontro Regional de História - O Lugar da História. ANPUH/SP - UNICAMP. Campinas, 6 a 10 de setembro de 2004.
} 
Nosso estudo acerca da compra e/ou venda de escravos em São Mateus na segunda metade do século XIX amparou-se, sobretudo, na análise do banco de dados construído com as informações recolhidas na consulta à doze livros do Notariado de São Mateus, nos quais identificamos a existência de um conjunto significativo de fontes reveladoras de diversos aspectos das relações escravistas naquela região.

Após exame do leque disponível desses documentos, constatamos que:

1. Os fluxos mercantis, envolvendo negócios com escravos, somaram o total de 606 escravos comprados e vendidos, em 460 documentos negociados entre 1863 e 1887. Entre os outros documentos cartoriais envolvendo atividade mercantil com escravos, há os classificados de 'avulsos' (por não se constituírem fontes seriais) tais como hipotecas, penhoras, permutas, contratos, doações, entre outros, somando-se 81 registros.

2. Em meio aos proprietários de escravos, seja nas compras, vendas, hipotecas ou penhoras, apesar de verificar-se um grande número de nomes/sobrenomes envolvidos nestas, um pequeno grupo de indivíduos se apresenta com destaque tanto no maior volume das quantias investidas, como também no número de escravos incluídos neste rol de transações mercantis. Entre os compradores registram-se 192 e entre os vendedores 268 nomes de proprietários.

No conjunto dessas fontes se destacam também as declarações e os registros de cartas de alforrias (objeto de análise no próximo capítulo) e o caráter extremamente mercantil que presidiu as relações escravistas na sociedade mateense, cujas evidências, a priori, são notadas no predomínio numérico das fontes cartorárias relativas aos registros das escrituras de compra e venda de escravos, além das hipotecas, permutas, declarações de dívidas e outros tipos de transações comerciais envolvendo o valor/preço dos escravos.

Deter-nos-emos neste capítulo numa análise mais aprofundada acerca das escrituras de compra e venda de escravos, considerando que estas perfazem o maior número neste conjunto de fontes, possibilitando que se obtenha uma visão mais ampla das características que permearam as relações mercantil-escravistas na região de São Mateus no período enfocado. 
3.1. Padrões de compra e venda de escravos em São Mateus na segunda metade do século XIX.

Mesmo considerando que os registros cartorários apresentam mudanças em seu formato no decorrer dos tempos, ao atentarmos para uma caracterização do teor dessas fontes, observamos que as escrituras de compra e venda de escravos são documentos que nos fornecem um conjunto de dados/informações de natureza semelhante (que refletem o contexto sociocultural e também a situação sócio-econômica e política da época em que foram produzidos), dentre as quais se destacam os nomes dos respectivos compradores e vendedores, suas patentes/titulações e posições sociais naquela sociedade, os nomes das testemunhas, o nome do escravo (sua idade, origem/etnia, cor, estado conjugal e ocupação) e o valor que presidiu a compra/ venda do escravo naquela ocasião.

Sendo assim, constatamos que as escrituras públicas de compra e venda de escravos da segunda metade do século XIX apresentam geralmente a mesma estrutura textual, contendo, de forma seqüencial, os seguintes dados e informações:

a) nome do cativo, nome do vendedor, nome do comprador, valor da comercialização;

b) data de emissão, lugar onde é lavrada;

c) endereço do vendedor e do comprador;

d) nome, sexo que é inferido do nome, origem, cor, idade, naturalidade, estado civil e profissão/ocupação do escravo;

e) observações quanto à forma de quitação, informes sobre o recolhimento do imposto de meia sisa - paga pelo comprador que, no ato, apresenta a certidão da meia siza emitida na Coletoria;

f) nome das testemunhas, quando existentes;

g) pessoas que assinam a rogo das partes contratantes, quando estas têm impedimentos;

h) fecho do tabelião e assinatura.

Ressaltamos que nos doze livros pesquisados no Cartório do $1^{\circ}$ Ofício Arnaldo Bastos em São Mateus (v. Tabela 1), localizamos um total de 460 escrituras de compra e venda, envolvendo um número aproximado de 606 escravos, negociados num intervalo de 25 anos, ou seja, entre 1863 e 1887, e em cujo período verifica-se uma maior dinamização no contexto da economia regional, motivada não somente pela introdução da lavoura cafeeira, mas também pelo aumento da produção da farinha de 
mandioca (principal atividade geradora de riquezas em todo o período analisado), e cujos efeitos promovem uma intensificação no comércio de escravos naquela região.

Assim, no evolver da pesquisa e nos documentos referentes à compra e/ou venda de escravos registrados nos Livros do Notariado de São Mateus, constatamos a existência de variados tipos e/ou formas de efetivação de tais atos comerciais, dentre os quais predominaram as escrituras de vendas ou compras individuais de escravos, nos quais também identificamos a ocorrência significativa de casos envolvendo compras ou vendas coletivas de vários escravos numa mesma escritura.

Ainda acerca da variação nos tipos de escrituras de compra ou venda de escravos, verificamos a ocorrência, em menor proporção, dos casos de compra ou venda da metade do escravo, além de outras situações mais atípicas, tais como a negociação de três quintas partes, da quinta parte ou da décima parte do valor de determinados escravos. Também foram identificados casos peculiares, como a venda "condicional” de um escravo, a venda de escravos que já se encontravam hipotecados com os respectivos compradores e uma escritura relativa à venda de escravos juntamente com bens imóveis.

Chama a atenção neste conjunto de fontes a grande ocorrência de escrituras que tratam da venda de escravas acompanhadas dos seus respectivos filhos ingênuos, sendo menos recorrente, porém, os registros que se referem à venda de casais de escravos, cujas situações remetem ao estudo da família escrava e ao tipo de tratamento dado à escravidão por certos proprietários de escravos daquela localidade.

Conforme se avançou na pesquisa (e do ponto de vista cronológico-linear das fontes), foi possível acompanhar a trajetória de alguns escravos comercializados várias vezes no decorrer do período, havendo situações em que estes eram comprados e, praticamente no mesmo dia, eram revendidos a preços mais elevados, o que reforça o caráter mercantil imputado por determinados indivíduos daquela sociedade no trato com a escravidão em nível local.

Nesta perspectiva, detectamos a existência de várias firmas e/ou empresas especializadas no comércio da compra ou venda de escravos, cujas denominações em sua maioria, se referem a nomes e/ou sobrenomes de famílias que compunham a oligarquia agrária e mercantil de âmbito regional. Em certos casos, tais firmas atuavam neste ramo comercial também na praça do Rio de Janeiro, para onde se direcionava o maior volume das exportações da farinha de mandioca de São Mateus. 
É oportuno ainda nesta parte do estudo, fornecer uma caracterização dos doze livros do Notariado objeto desta pesquisa, com foco privilegiado no conjunto dos registros de compra e venda de escravos contidos nos mesmos (v. Tabela 1), haja vista que tais livros apresentam diferenças entre si no que tange aos períodos abarcados, ao quantitativo desse tipo de fonte neles registradas e também ao formato de transcrição das escrituras de compra e venda de escravos que trazem.

Acerca deste último aspecto mencionado, observamos que há um divisor de águas por volta de 1873, pois, a partir deste ano, a elaboração das escrituras de compra e/ou venda de escravos passa a destacar detalhadamente os dados e as informações referentes à matrícula do escravo e também à sua averbação, constando nestas, inclusive, as respectivas datas e os locais onde as mesmas foram efetivadas.

Acreditamos que tal situação decorre da obediência às mudanças na legislação relativa à escravidão no período, sobretudo no que tange aos procedimentos inerentes à transferência de escravos e a arrecadação do imposto da meia sisa. Neste sentido, o lançamento das escrituras públicas de compra e venda de escravos deveria estar de acordo com o Artigo $1^{\circ}$ do Decreto $\mathrm{n}^{\circ} .2 .833$, de 12 de outubro de 1861.

Ainda acerca da legislação vigente à época, nota-se que as escrituras públicas deveriam ser lavradas nas cidades e vilas pelos tabeliães de notas e, nas freguesias ou capelas fora das cidades ou vilas, por um Juiz de Paz, conforme determinava a Lei de 30 de outubro de 1830, presente na Coleção das Leis do Império. ${ }^{166}$

Em suma, a escritura pública de compra e venda de escravos na segunda metade do século XIX representava a declaração pública de um negócio jurídico definitivo, irrevogável e quitado, elaborada no momento mesmo da comercialização do escravo enquanto propriedade de outrem. Tinha, portanto, validade como documento oficial, cuja finalidade era colocar o Estado a par do que estava sendo comercializado e assegurar os direitos do vendedor e do comprador, assim como o pagamento dos impostos respectivos. Tais relações econômico-sociais eram formalizadas na escritura, haja vista que sobre a compra do escravo incidia a meia sisa - imposto cobrado em negociações inter vivos, ou seja, imposto de transmissão pago pelo comprador quando o negócio realizado ultrapassava os duzentos mil réis.

\footnotetext{
${ }^{166}$ Cf. NASCIMENTO, Jarbas V. \& NARDOCCI, Izilda Maria. Compra e venda de homens negros: uma prática cartorial no século XIX. In: Academos, Revista Eletrônica da FIA, Vol. II N. 2 Jul - Dez/2006, p. $1-11$.
} 
Tabela 1: Dados gerais da compra e venda de escravos em doze Livros de Notas de São Mateus (1863-87)

\begin{tabular}{cccccr}
\hline $\mathrm{N}^{\circ}$. LIVRO & PERIODO ABARCADO & $\mathrm{N}^{\circ}$. ESCRITURAS & $\%$ & $\mathrm{~N}^{\circ}$. ESCRAVOS & $\%$ \\
\hline 1 & $13 / 06 / 1863$ a $23 / 01 / 1867$ & 22 & 4,7 & 25 & 4,1 \\
2 & $02 / 02 / 1867$ a 04/01/1873 & 83 & 18,2 & 106 & 17,5 \\
4 & $30 / 06 / 1870$ a 01/02/1873 & 37 & 8,1 & 47 & 7,7 \\
5 & $14 / 03 / 1873$ a 26/10/1874 & 59 & 12,8 & 85 & 14,2 \\
6 & $07 / 03 / 1873$ a 05/11/1877 & 40 & 8,6 & 43 & 7,0 \\
7 & $19 / 12 / 1874$ a 13/06/1878 & 67 & 14,7 & 79 & 13,1 \\
10 & $18 / 02 / 1878$ a 30/08/1879 & 16 & 3,5 & 21 & 3,5 \\
11 & $13 / 06 / 1878$ a 01/10/1880 & 53 & 11,5 & 86 & 14,1 \\
12 & $23 / 04 / 1880$ a 22/03/1884 & 32 & 6,9 & 49 & 8,1 \\
15 & $04 / 11 / 1880$ a 29/03/1884 & 30 & 6,5 & 44 & 7,3 \\
18 & $10 / 03 / 1884$ a 24/05/1887 & 12 & 2,6 & 13 & 2,1 \\
19 & $09 / 04 / 1884$ a 12/04/1887 & 09 & 1,9 & 08 & 1,3 \\
TOTAL & $\mathbf{2 5}$ anos & $\mathbf{4 6 0}$ & $\mathbf{1 0 0 , 0}$ & $\mathbf{6 0 6}$ & $\mathbf{1 0 0 , 0}$ \\
\hline
\end{tabular}

Fonte: Cartório do 1ํ Ofício de São Mateus.

Conforme podemos observar no exposto na Tabela 1, o registro das escrituras públicas de compra e/ou venda de escravos em São Mateus, suscita determinadas questões e apresenta as seguintes configurações básicas:

1. As lacunas existentes na sequiência dos números dos livros arrolados na coluna $n^{o}$. do livro da tabela, onde não constam os livros de $\mathrm{n}^{\circ} .3,8,9,13$ e 14 , se justifica pelo fato de que os referidos livros foram dedicados especificamente ao lançamento de procurações;

2. A diferença para mais existente entre o número de escravos comercializados (606) e o número total das escrituras arroladas (460) se explica pelo fato de que diversas escrituras tratam de compras ou vendas duplas (2 escravos) e/ou de compras ou vendas coletivas (vários escravos negociados na mesma escritura);

3. A seqüência numérica crescente dos livros não obedece necessariamente à sequiência cronológica dos registros de compra e venda de escravos, haja vista que escrituras referentes a um mesmo ano são registradas concomitantemente em diferentes livros, a saber: escrituras referentes ao ano de 1867 são encontradas no conjunto dos registros dos Livros 1 e 2; escrituras referentes ao ano de 1873 são encontradas no conjunto dos registros dos Livros 2, 4 e 5; escrituras referentes ao ano de 1877 são encontradas no conjunto dos registros dos Livros 6 e 7; escrituras referentes ao ano de 1878 são encontradas no conjunto dos registros dos Livros 7, 10 e 11; escrituras referentes ao ano de 1880 são encontradas no conjunto dos registros dos Livros 11, 12 e 15; escrituras referentes ao ano de 1884 são encontradas no conjunto dos registros dos Livros 
12, 15, 18 e 19; e, finalmente, nos Livros 18 e 19 são registradas escrituras referentes a um mesmo período, qual seja, de 1884 a 1887;

4. Acerca dos livros contendo o maior número de escrituras de compra ou venda de escravos e também o maior contingente dos escravos comercializados em São Mateus no referido período, nota-se que o Livro 2 concentra o maior quantitativo de escrituras (18,2\% do total) e o maior número de escravos comercializados $(17,5 \%$ do total), haja vista que o mesmo também abarca um maior intervalo de tempo desses registros, ou seja, 7 anos (1867 a 1873), considerando que a média de abrangência temporal dos registros dos demais livros (8 livros) gira em torno de 4 a 5 anos (Cf. Livros 1,4,6,7,12,15,18 e 19);

5. Na observação dos dados reunidos na Tabela 1 se podem ainda destacar as conjunturas de maior dinamização dos negócios envolvendo a compra/ venda de escravos em São Mateus, onde se nota que os picos mais significativos neste sentido foram registrados nas décadas de 1860 e 1870 (que reúnem uma média de $80 \%$ do total dos escravos negociados), sobretudo nos anos de 1870 quando se verifica a maior quantidade dos negócios dessa natureza;

6. Também sobressai nesta amostragem que tal dinâmica decai no decorrer dos anos de 1880, quando o percentual de vendas e compras de escravos apresenta quedas vertiginosas em relação às duas décadas precedentes, abarcando uma média de $20 \%$ do total dos escravos comercializados no período;

7. As tendências apontadas nos itens 5 e 6 acima expostos podem ser explicadas levando-se em conta a variação da conjuntura político-econômica que marcou o contexto da escravidão no país na segunda metade do Oitocentos - a exemplo da proibição do tráfico de escravos em 1850 e o crescimento da lavoura cafeeira demandando maior contingente de mão-de-obra escrava -, além de se observar também as variações conjunturais verificadas no contexto da economia regional.

É interessante ressaltar que estas escrituras são documentos que fornecem os preços dos escravos de forma mais próxima dos valores de mercado, embora não abrangendo parcela tão representativa da população cativa, a exemplo das Listas de Classificação de Escravos para o Fundo de Emancipação, produzidas em meados da 
década de 1870, que contém também avaliações individuais dos escravos arrolados ${ }^{167}$. Lamentavelmente, estas Listas de Classificação de Escravos da Província do Espírito Santo não foram localizadas até o momento, não se sabendo se encontram irremediavelmente perdidas ou destruídas.

\subsubsection{Perfil dos compradores e dos vendedores de escravos.}

Para traçarmos o perfil dos compradores e dos vendedores de escravos em São Mateus, na segunda metade do Oitocentos, é necessário fazermos uma breve retrospectiva dos principais proprietários rurais mateenses no período estudado, os quais estavam interligados por laços consanguiíneos, formando uma espécie de oligarquia rural e mercantil de base familiar, representada pelo Barão de Aimorés. A expansão cafeeira na província capixaba além de implicar na expansão da escravidão, acarretou a formação de poucos, mas autênticos grupos oligárquicos assentados na grande propriedade rural com base escravista.

Conforme já ressaltamos no Capítulo 1, em meados do século XIX dá-se início à formação de uma oligarquia agrária e mercantil mateense, representada pelo major Cunha, mais conhecido na história de São Mateus como Barão de Aimorés, e que esta oligarquia assentava-se em bases nitidamente escravocratas.

A introdução da cultura do café em São Mateus associada à grande produção da farinha e ao comércio de escravos ocasionou a efetivação dessa oligarquia, possuidora de patentes da Guarda Nacional, a qual exerceu influência na política local e também junto ao governo provincial.

Numa conjuntura favorável, um dos primeiros fazendeiros a fazer investimentos no café nas terras mais a oeste do município de São Mateus, foi Antonio Rodrigues da Cunha, o major Cunha ${ }^{168}$.

\footnotetext{
${ }^{167}$ Cf. MOTTA, J. Flávio \& MARCONDES Renato L. Duas fontes documentais para o estudo dos preços dos escravos no Vale do Paraíba paulista. Revista Brasileira de História. São Paulo, v. 21, nº42, 2001.

168 A família Cunha, além de proprietária de terras e de escravos, era proprietária também de meio de transporte para sua produção, como podemos verificar no Relatório do Presidente da Província do Espírito Santo Luís Antonio F. Pinheiro, de 22/09/1868, no Mappa dos Navios pertencentes à Província do Espírito Santo (Biblioteca Digital do APEES, publicação de 1869, p. 75). O Presidente Pinheiro lista doze embarcações no porto de São Mateus. Entre estas, duas são propriedade de Antonio Rodrigues da Cunha (uma sumaca de nome Especuladora, e um hiate, o Santa Rosa). Outra embarcação era de D. Leocádia da Cunha, filha do primeiro casamento do Barão (com Dona Tomásia, filha do Barão de Itapemirim), o patacho Vênus. Leocádia era casada com Antonio Gomes Sodré, grande proprietário de
} 
A partir de 1863 o Major inicia a colonização do interior da região de São Mateus, implantando algumas fazendas a oeste, seguido por alguns irmãos, cunhados e outros parentes, os quais, também, intencionavam o cultivo do café. Entre a extensa parentela do Major, podemos citar algumas famílias, sendo as mais notórias, os Santos Neves, os Gomes Sodré, os Abel de Almeida, os Faria Lima, os Silvares, entre outras, todas originárias da grande propriedade rural estruturada em bases escravistas.

O início da expansão do café em São Mateus a partir de 1860, coincide com a data dos primeiros registros cartoriais relacionados a escravos (1863), tais como as alforrias e as escrituras de compra e venda de escravos. Nestes documentos, os vários nomes de proprietários de escravos, de compradores e vendedores, de alforriados e alforriandos, estão registrados repetidas vezes.

Tabela 2: Percentual de escravos comprados pelos 10 maiores compradores em São Mateus (1863-1887).

\begin{tabular}{lcc}
\hline Comprador & Escravos comprados & Percentual \\
\hline 1- Antonio Rodrigues da Cunha & 45 & 7,4 \\
2 - Domingos Rocha da Silva Rios & 29 & 4,8 \\
3 - Matheus Gomes da Cunha & 27 & 4,5 \\
4 - Jacintho José Rodrigues & 18 & 3,0 \\
5 - Raulino Francisco de Oliveira & 17 & 2,8 \\
6 - José Joaquim de Almeida Fundão & 15 & 2,5 \\
7 - João dos Santos Neves & 14 & 2,3 \\
8 - João Gomes dos Santos & 14 & 2,3 \\
9 - Leonel Joaquim Fundão \& Cia & 14 & 2,3 \\
10 - Manoel José Rodrigues Oliveira & 14 & 2,3 \\
Total de escravos comprados & 207 & 34,2 \\
Outros escravos negociados & 399 & 65,8 \\
& & \\
Total geral & 606 & 100,0 \\
\hline
\end{tabular}

Fonte: Cartório de 1ํo Ofício de São Mateus.

Podemos observar na Tabelas 2, que o nome de Antonio Rodrigues da Cunha consta como o maior comprador de escravos no período estudado (45 escravos comprados), e como um dos 10 maiores vendedores (8 escravos vendidos - v. Tabela 3). Seu irmão Mateus Gomes da Cunha vem em terceiro lugar entre os compradores, e a firma de seu sogro, Leonel Joaquim Fundão \& Cia (pai de Ercília, sua terceira esposa), figura em nono lugar.

terras. Também o nome de Leonel Joaquim de Almeida Fundão (que figura na lista dos 10 maiores compradores de escravos), consta como proprietário da lancha Lago, dentre outros nomes de proprietários relacionados nos registros de compra e venda de escravos. 
Em segundo lugar vem o nome de Domingos Rocha da Silva Rios, alferes e destacado proprietário de terras, entre os maiores compradores (29 escravos comprados), aparecendo também como um dos 10 maiores vendedores (12 escravos vendidos - v. Tabela 3 )

Em terceiro, como já nos referimos, figura o nome de Mateus Gomes da Cunha irmão de Antonio Rodrigues da Cunha -, coronel da Guarda Nacional e proprietário da Fazenda Boa Esperança, com 27 escravos comprados.

Uma firma também aparece na lista dos maiores compradores, a Leonel Joaquim Fundão \& Cia, com a compra de 14 escravos entre 1878 e 1884.

Igualmente uma firma (empresa) comercializadora de escravos aparece na lista dos 10 maiores vendedores de escravos: a Faria \& Bastos, do Rio de Janeiro, que em dois documentos (dois registros cartoriais) realiza a venda de 24 escravos, em 1873. Um registro especifica a venda de 10 escravos por 6:900\$000 rs. e o outro registro especifica 14 escravos com duas-metades já forras, por 8:350\$000 rs. As duas escrituras de venda dos 24 escravos, pela firma Faria \& Bastos, tiveram por comprador Antonio Rodrigues da Cunha. Todos os escravos negociados estavam matriculados na Colecttoria Geral do município, incluindo várias crianças, sendo que o escravo mais velho estava com apenas 41 anos de idade.

Tabela 3: Percentual de escravos vendidos pelos 10 maiores vendedores em São Mateus (1863-1887).

\begin{tabular}{lcc}
\hline Vendedor & Escravos vendidos & Percentual \\
\hline 1 - Andrelino Leite de Barcellos & 26 & 4,3 \\
2 - Faria \& Bastos & 24 & 4,0 \\
3 - Ana Luiza Gomes H. Paiva & 22 & 3,6 \\
4 - Francisco Vicente Dutra & 14 & 2,3 \\
5 - Domingos Rocha da Silva Rios & 12 & 2,0 \\
6 - Lourenço Bernardo Vieira & 11 & 1,8 \\
7 - Francisca Romana Lopes/outros & 11 & 1,8 \\
8 - Leopoldo Smith de Vasconcellos & 11 & 1,8 \\
9 - Raulino Francisco de Oliveira & 9 & 1,5 \\
10 - Antonio Rodrigues da Cunha & 8 & 1,3 \\
Total de escravos vendidos & 148 & 24,4 \\
Outros escravos negociados & 458 & 75,6 \\
& & \\
Total geral & 606 & 100,0 \\
\hline
\end{tabular}

Fonte: Cartório de 1o Ofício de São Mateus.

Entre os vendedores escravocratas figura em primeiro lugar o nome do alferes Andrelino Leite de Barcellos, que, embora não tenhamos encontrado referências dele 
com a parentela do Barão, é possível que seja filho ou neto de Antonio Leite Barcellos, um dos nomes presentes na ata de fundação da Vila em 1764, provavelmente grande proprietário de terras.

Os nomes de duas mulheres aparecem na lista dos vendedores, Ana Luiza Gomes H. Paiva (esposa do doutor Honório Gomes de Paiva Coutinho) e Francisca Romana Lopes (cujas vendas são feitas em sociedade com outros), ambas da elite local. Ana Luíza aparece na lista dos 10 principais compradores com 5 escravos comprados em 1882.

Os 10 maiores compradores equivalem a 5,2\% do total de compradores e compraram $34,2 \%$ dos escravos comprados. Os 10 maiores vendedores equivalem a $3,7 \%$ do total de vendedores e venderam $24,4 \%$ dos escravos vendidos. Isso significa que há uma concentração tanto no mercado de compra quanto no de venda, sendo o mais concentrado o de compra, o que equivale a um oligopólio na estrutura de mercado de venda de escravos, e a um oligopsônio na estrutura de mercado de compra de escravos.

As Tabelas 2 e 3 confirmam a alta concentração de cativos nas mãos de um grupo restrito de proprietários, mas, indicam também que a propriedade escrava em São Mateus estava distribuída em amplos setores da sociedade local, não importando a extensão das posses, visto que o restante dos escravos foram negociados por 182 compradores (num total de 192) e por 258 vendedores (num total de 268). (v. Tabelas 6 e 7)

\begin{tabular}{|c|c|c|}
\hline Patente & Frequência & Percentual \\
\hline$\overline{\text { Capitão }}$ & 8 & 4,2 \\
\hline $\begin{array}{l}\text { Empresário/ } \\
\text { Negociante }\end{array}$ & 7 & 3,6 \\
\hline Tenente & 6 & 3,1 \\
\hline Doutor & 4 & 2,1 \\
\hline Alferes & 1 & 0,5 \\
\hline $\begin{array}{l}\text { Padre/Vigário/ } \\
\text { Reverendo }\end{array}$ & 1 & 0,5 \\
\hline Coronel & 1 & 0,5 \\
\hline Preto forro & 1 & 0,5 \\
\hline Major & 1 & 0,5 \\
\hline Nada consta & 162 & 84,4 \\
\hline Total & 192 & 100,0 \\
\hline
\end{tabular}


Para traçarmos um perfil mais detalhado dos compradores/vendedores de escravos, uma outra variável importante deve ser avaliada: a patente dos negociadores.

Observando as Tabela 4 e 5, vemos que é nítida a presença dos elementos da Guarda Nacional com patentes mais elevadas. Entre os compradores destacam-se 8 capitães, 6 tenentes, 1 coronel, 1 major e 1 alferes, Entre os vendedores destacam-se 4 capitães, 4 tenentes, 1 coronel, 1 major e um 1 alferes.

Tabela 5: Patente dos vendedores de escravos em

\begin{tabular}{lcc}
\multicolumn{3}{c}{ São Mateus (1863-1887). } \\
\hline Patente & Frequência & Percentual \\
\hline $\begin{array}{l}\text { Empresário/Nego } \\
\text { ciante }\end{array}$ & 8 & 3,0 \\
Doutor & 5 & 1,9 \\
Tenente & 4 & 1,5 \\
Capitão & 4 & 1,5 \\
Alferes & 1 & 0,4 \\
Padre/Vigário/ & 1 & 0,4 \\
Reverendo & & 0,4 \\
Coronel & 1 & 0,4 \\
Falecido & 1 & 0,4 \\
Major & 1 & 0,4 \\
Desembargador & 1 & 89,9 \\
& & 100,0 \\
Nada consta & 241 & \\
Total & 268 & \\
\hline Fonte: Cartório de 10 Ofício de São Mateus.
\end{tabular}

Fonte: Cartório de 1ํo Ofício de São Mateus.

Sabemos que a única patente de major figurada nas Tabela 4 e 5 corresponde a Antonio Rodrigues da Cunha (Barão de Aimorés); a única de coronel entre os compradores é a de Matheus Gomes da Cunha (irmão de Aimorés), e a única entre dos vendedores é de Matheus Antonio dos Santos (da Vila da Barra), assim como o padre/vigário é o mesmo para os dois tipos de negócios, o reverendo José Pereira Duarte Carneiro. O único alferes entre os compradores trata-se de Andrelino Leite Barcellos (já citado) e o único entre os vendedores é a de Miguel Teixeira Sarmento.

Em segundo lugar vem a patente/ocupação de empresário/negociante (8 para os vendedores e 7 para os compradores), incluídas também nesse rol as firmas comercializadoras, seguida, em terceiro lugar pela de doutor (4 compradores e 5 vendedores). O destaque para o único desembargador entre os vendedores, coube a Júlio César Bittencourt.

Entre os capitães mencionados nas compras/vendas de escravos temos o nome de Luís José dos Santos Guimarães, proprietário da firma Luís José dos Santos Guimarães 
\& Cia, a qual retornaremos mais adiante quando tratarmos do mercado de escravos e das firmas comercializadoras de escravos em São Mateus.

Em relação à Tabela 6 podemos observar que o maior número de compradores (95), praticamente a metade dos 192, compraram apenas 1 escravo, correspondendo a um percentual de 49,5\%, ao passo que 1 comprador apenas chega a comprar 45 escravos (Antonio Rodrigues da Cunha), seguido por outro que compra 29 escravos (Domingos da Silva Rios) e por um terceiro que compra 27 escravos (Matheus Gomes da Cunha). (v. também Tabela 2)

Tabela 6: Percentual do número de compradores de escravos em São Mateus (1863-1887).

\begin{tabular}{ccccc}
\hline $\begin{array}{c}\mathrm{N}^{\mathbf{0}} \text {. de escravos } \\
\text { negociados }\end{array}$ & $\mathrm{N}^{\mathbf{0}}$. de compradores & $\begin{array}{c}\text { \% de } \\
\text { compradores }\end{array}$ & $\begin{array}{c}\text { Total de escravos } \\
\text { negociados }\end{array}$ & $\begin{array}{c}\text { \% de escravos } \\
\text { negociados }\end{array}$ \\
\hline 1 & 95 & 49,5 & 95 & 15,6 \\
2 & 34 & 17,7 & 68 & 11,2 \\
3 & 20 & 10,4 & 60 & 9,9 \\
4 & 10 & 5,2 & 40 & 6,6 \\
5 & 11 & 5,7 & 55 & 9,1 \\
6 & 8 & 4,2 & 48 & 1,9 \\
7 & 1 & 0,5 & 7 & 2,6 \\
8 & 2 & 1,0 & 16 & 1,7 \\
10 & 1 & 0,5 & 10 & 9,2 \\
14 & 4 & 2,1 & 56 & 2,5 \\
15 & 1 & 0,5 & 15 & 2,8 \\
17 & 1 & 0,5 & 17 & 3,0 \\
18 & 1 & 0,5 & 18 & 4,5 \\
27 & 1 & 0,5 & 27 & 4,8 \\
29 & 1 & 0,5 & 29 & 7,4 \\
45 & 1 & 0,5 & 45 & 100,0 \\
\hline Total & 192 & 100,0 & 606 &
\end{tabular}

Entre os vendedores de escravos (v. Tabela 7), 168 venderam apenas 1 escravo, correspondendo a um percentual de $62,7 \%$, ao passo que 1 vendedor apenas (Andrelino Leite Barcellos) chegou a vender 26 escravos, seguido por outro que vende 24 (a firma Faria \& Bastos) e por um terceiro que vende 22 (Ana Luíza Gomes H. Paiva). (v. também Tabela 3)

Enfim, podemos concluir que num conjunto de 2.813 escravos existentes em São Mateus, por exemplo em 1872, boa parte (606 escravos que corresponde a 21,5\%) aparecem envolvidos nas transações de compra e venda, ou seja, devem ter sido jogado nesse mercado transferidos de proprietários. 
Tabela 7: Percentual do número de vendedores de escravos em São Mateus (1863-1887).

\begin{tabular}{crrrr}
\hline $\mathrm{N}^{\mathbf{}}$. de escravos negociados & $\mathrm{N}^{\mathbf{o}}$. de vendedores & $\%$ de vendedores & $\begin{array}{c}\text { Total de escravos } \\
\text { negociados }\end{array}$ & $\begin{array}{c}\% \text { de escravos } \\
\text { negociados }\end{array}$ \\
\hline 1 & 168 & 62,7 & 168 & 27,7 \\
2 & 39 & 14,6 & 78 & 12,8 \\
3 & 20 & 7,4 & 60 & 10,0 \\
4 & 15 & 5,5 & 60 & 10,0 \\
5 & 8 & 3,0 & 40 & 6,6 \\
6 & 5 & 1,8 & 30 & 4,9 \\
7 & 3 & 1,1 & 21 & 3,4 \\
8 & 1 & 0,4 & 8 & 1,5 \\
9 & 1 & 0,4 & 9 & 5,4 \\
11 & 3 & 1,1 & 33 & 2,0 \\
12 & 1 & 0,4 & 12 & 2,3 \\
14 & 1 & 0,4 & 14 & 3,8 \\
23 & 1 & 0,4 & 23 & 4,0 \\
24 & 1 & 0,4 & 24 & 4,3 \\
26 & 1 & 0,4 & 26 & 100,0 \\
\hline
\end{tabular}

Fonte: Cartório de 1ㅇ Ofício de São Mateus.

3.1.2. Perfil dos escravos: sexo, idade, preços, origem e outras variáveis.

Idade e sexo dos escravos negociados em São Mateus.

Como podemos verificar na Tabela 8 , os homens constituem o maior número (326) de escravos comprados/vendidos em São Mateus entre 1863 e 1887, atingindo um percentual de 53,8\% do total, ao passo que as mulheres (269) representam 44,4\%.

Tabela 8: Sexo dos escravos comprados/vendidos em São Mateus (1863-1887).

\begin{tabular}{lcc}
\hline & Frequência & Percentual \\
\hline Homens & 326 & 53,8 \\
Mulheres & 269 & 44,4 \\
Não se sabe & 11 & 1,8 \\
Total & 606 & 100,0 \\
\hline
\end{tabular}

Fonte: Cartório de 1o Ofício de São Mateus.

Gráfico1: Sexo dos escravos comprados/vendidos em São Mateus (1863-1887).

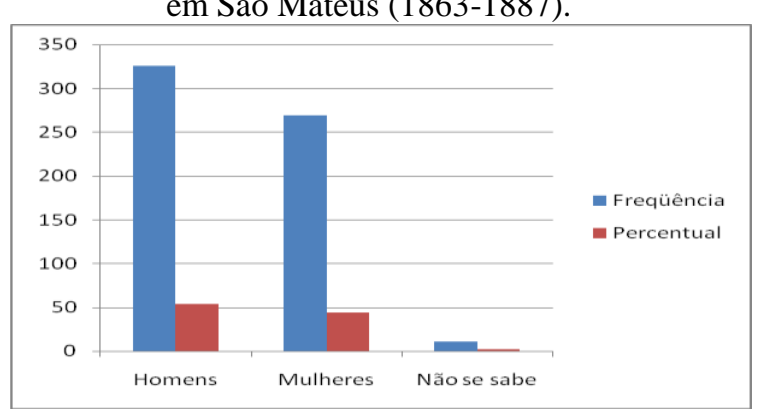

Fonte: Cartório de 1o Ofício de São Mateus. 
Para 11 escravos não foi possível identificar o sexo, pois se tratam de 2 escrituras, em que uma se refere a uma venda coletiva de escravos, não especificando o nome do escravo, e outra que, embora seja venda individual não foi possível identificar o nome do escravo no documento. Sem os nomes não foi possível identificar o sexo. Estas escrituras deram prioridade à importância paga/recebida pela negociação e o número de escravos envolvidos, não se preocupando com outras referências, tais como nome e idade do cativo.

Desses 606 escravos comprados e vendidos, em 388 não consta a idade, ou seja, em 64\% das negociações não houve referências a essa variável. (v. Tabela 9)

Tabela 9: Idade dos escravos comprados/vendidos em São Mateus (1863-1887).

\begin{tabular}{|c|c|c|c|c|c|}
\hline \multirow{2}{*}{$\begin{array}{l}\text { Idade } \\
\text { escravo }\end{array}$} & \multicolumn{3}{|c|}{ Sexo do escravo } & \multirow[t]{2}{*}{ Total } & \multirow[t]{2}{*}{$\%$} \\
\hline & Não se sabe & Homens & Mulheres & & \\
\hline $0-14$ & - & 25 & 22 & 47 & 7,7 \\
\hline $15-19$ & - & 15 & 15 & 30 & 4,9 \\
\hline $20-24$ & - & 17 & 20 & 37 & 6,1 \\
\hline $25-29$ & - & 22 & 14 & 36 & 5,9 \\
\hline $30-34$ & - & 9 & 11 & 20 & 3,3 \\
\hline $35-39$ & - & 3 & 7 & 10 & 1,7 \\
\hline $40-44$ & - & 12 & 9 & 21 & 3,5 \\
\hline $45-49$ & - & 4 & 2 & 6 & 1,0 \\
\hline $50-54$ & - & 4 & 3 & 7 & 1,2 \\
\hline $55-59$ & - & - & - & - & - \\
\hline $60-64$ & - & 2 & 1 & 3 & 0,5 \\
\hline $65-70$ & - & 1 & - & 1 & 0,2 \\
\hline Total & - & 114 & 104 & 218 & 36,0 \\
\hline Não consta & 11 & - & - & 388 & 64,0 \\
\hline Total geral & 11 & 326 & 269 & 606 & 100,0 \\
\hline
\end{tabular}

Fonte: Cartório de 1o Ofício de São Mateus.

Apenas $36 \%$ destas negociações contém a variável idade, reduzindo expressivamente a quantificação da amostragem, para apenas 218 escravos. Entre estes, a faixa etária predominante (excetuando as crianças de 0 a 14 anos) foi a de 20 e 24 anos, com um total de 37 escravos, seguido pela de 25-29 anos com 36 escravos. Após os 30 anos o número de escravos decresce, sendo que na faixa dos 40- 44 há um pequeno acréscimo percentual.

Não deixa de ser curioso o fato de apenas 1 escravo possuir a idade de 70 anos, e apenas 3 a de 60 anos, tornando evidente a baixa expectativa de vida. 
Se considerarmos crianças os escravos de até 14 anos (sabemos que na realidade essa idade era menos) temos 47 registros destes $(7,8 \%)$, o que pode ser considerado um número razoável de crianças entre os comprados/vendidos. (v. Tabela 9)

Das 47 crianças arroladas, 22 são do sexo feminino e 25 do masculino, denotando um percentual quase equilibrado entre os dois sexos e confirmando uma tendência geral da província, pois no Espírito Santo havia equilíbrio na proporção entre os sexos dos escravos ${ }^{169}$. Esta situação é atribuída à especificidade adquirida pelo surto cafeeiro na província, que devido ao fato de ser introduzido tardiamente, parece ter se adaptado às dificuldades decorrentes do fim do tráfico de africanos, sendo que esta proporção parece resultar dos percentuais equilibrados de nascimentos.

Entre os 218 escravos comprados/vendidos, 154 - que equivalem a 70\% - estão inseridos na faixa etária mais produtiva, ou seja, entre 15 a 44 anos. (v. Tabela 9) Apenas 17 estão acima dos 45 anos, ao passo que 47 são abaixo de 15 anos.

Entre os 218 escravos comprados/vendidos que possuem a idade (113 homens e 105 mulheres), temos a predominância da idade de 25 anos (27 escravos - v. ANEXO 2/ Tabela 1) sendo entre estes, 17 homens e 10 mulheres; com a idade de 30 anos o número de mulheres se mantém (10 escravos) ao passo que o número de homens cai acentuadamente (de 17 para 7). Isto talvez poderia ser explicado pela desvantagem da predominância de homens nos trabalhos da lavoura, mas por se tratar de uma faixa etária ainda jovem não podemos afirmar com mais precisão. Embora o número de homens decresça, porém se observarmos a idade de 40 anos, um relativo equilíbrio entre os sexos é alcançado (7 homens e 9 mulheres), praticamente igual ao mesmo número de homens (7) e de mulheres (10) da idade de 30 anos. (v. ANEXO 2/ Tabela 1)

Pesquisando nos inventários a idade da população escrava jovem da província, considerando que esta estava incluída na faixa etária dos 16 e 40 anos, Almada constatou que no decorrer da segunda metade do século XIX, nas unidades produtivas de Cachoeiro do Itapemirim, ela variou muito decaindo na década de 1880, enquanto em Vitória, embora também variasse, ela recrudesce.

Nas escrituras de compra/venda de escravos em São Mateus evidenciamos a mesma tendência em relação às variações de idades na faixa etária produtiva, embora tenhamos considerado esta entre 15 e 44 anos (um pouco mais ampla que a de Almada)

${ }^{169}$ Cf. ALMADA, 1984, p.126. 
o que altera pouco as análises, e embora não tenhamos arrolados os dados segundo as variáveis década e idade.

Preços dos escravos negociados em São Mateus.

Os preços dos cativos variavam em função de fatores diversos tais como o sexo, a idade, o ofício, a condição física, dentre outros, além de estarem sujeitos às variações de conjunturas específicas ou das particularidades dos lugares de aquisição.

A exemplo de Minas e, de modo mais geral no Brasil, o aumento dos preços dos escravos no começo da década de 1850 , pode ter sido uma primeira conseqüência ao súbito encerramento do comércio escravagista.

\section{Segundo Bergard,}

as tendências paralelas de aumento destes preços encontradas em outros cantos das Américas mostram que havia razões mais que fundamentais de longo prazo para tais aumentos. Estas razões giravam em torno das complexas variáveis econômicas que funcionavam nos países escravistas e pelo mundo afora. Contudo, é provável que os preços tenham subido naquela década [1850] por causa da demanda européia dos produtos básicos do Novo Mundo e do aumento na produtividade e lucratividade da mão-de-obra escrava. Se os valores dos escravos subiram demais, pode-se pressupor que a elevação da demanda causou a elevação dos preços, e isto, por sua vez refletia a maior lucratividade de suas atividades econômicas. ${ }^{170}$

Para esse autor, o preço do trabalho escravo subiu na década de 1850 devido a fatores econômicos mais essenciais, como o aumento das demandas da produtividade e das mercadorias e não devido à rápida crise causada pelo fim do tráfico. Assim, entre essas mudanças estavam os aumentos dos preços internacionais para produtos básicos como o algodão, o açúcar e o café. ${ }^{171}$

Embora essa explicação seja adequada também para o caso do Brasil, sabemos que a razão principal para o aumento dos preços dos escravos aqui girava mais em torno do corte da entrada dos cativos associada à demanda da mão-de-obra para o café.

No Brasil, a questão do preço do escravo, que aumentou gradativamente após 1850, tornou-se nitidamente tensa após a criação do Fundo de Emancipação em 1871(e

${ }^{170}$ BERGARD, Lair W. Escravidão e História Econômica - demografia de Minas Gerais, 1720-1888. Bauru: EDUSC, 2004, p. 252.

${ }^{171}$ Cf. Carlos Roberto Antunes dos Santos, Preços de escravos na Província do Paraná: 18611887(Estudo sobre as escrituras de compra e venda de escravos), 1974 e Pedro Carvalho de Mello. A Economia da escravidão nas fazendas de café: 1850-1888. R.J., PNPE,1984, mimeo, vol.I. 
de sua regulamentação a partir de 1872). Nesse momento verifica-se uma tendência de supervalorização no preço dos cativos arrolados. ${ }^{172}$

Tabela 10: Número de escravos comprados/vendidos por sexo e por décadas em São Mateus (1863-1887).

\begin{tabular}{|c|c|c|c|c|c|c|c|c|}
\hline \multirow[t]{2}{*}{ Década } & \multicolumn{6}{|c|}{ Sexo do escravo } & \multirow[b]{2}{*}{ Total } & \multirow[b]{2}{*}{$\%$} \\
\hline & Homens & $\%$ & Mulheres & $\%$ & Não se sabe & $\%$ & & \\
\hline $1860-69$ & 52 & 8,6 & 52 & 8,6 & - & - & 104 & 17,2 \\
\hline $1870-79$ & 200 & 33,0 & 170 & 28,0 & 1 & 0,2 & 370 & 61,0 \\
\hline $1880-87$ & 74 & 12,2 & 47 & 7,8 & 10 & 2,0 & 132 & 21,8 \\
\hline Total & 326 & 53,8 & 269 & 44,4 & 11 & 2,2 & 606 & 100,0 \\
\hline
\end{tabular}

Fonte: Cartório de 1ㅇ Ofício de São Mateus.

Gráfico 2: Número de escravos comprados/vendidos por sexo e por décadas em São Mateus (1863-1887).

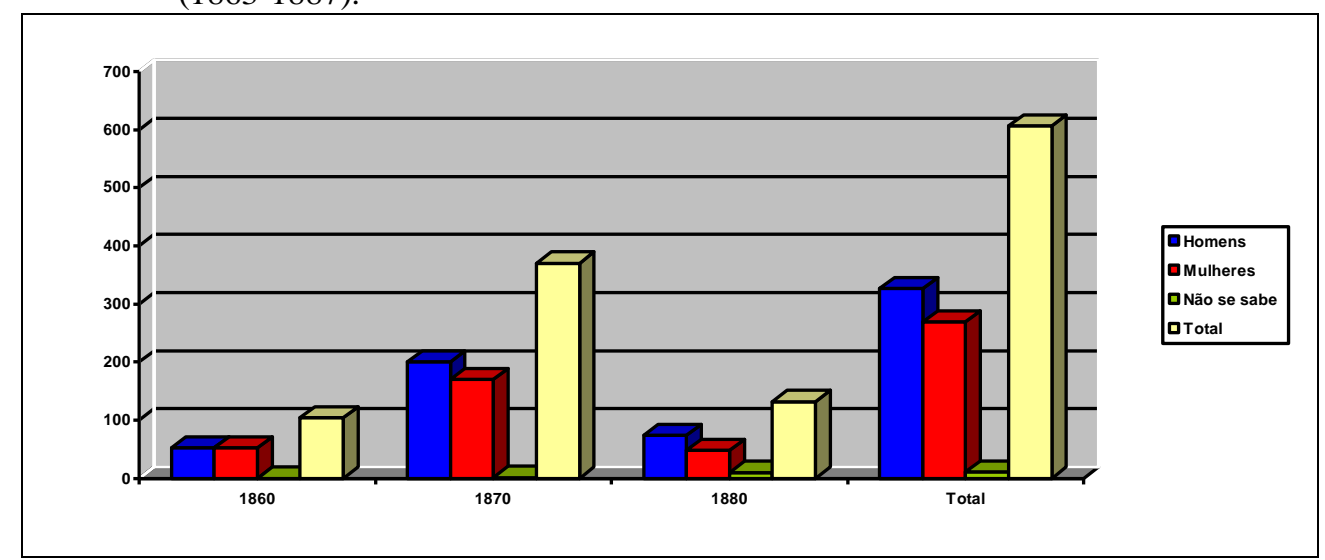

Fonte: Cartório de 1ㅇ Ofício de São Mateus.

O caso de São Mateus não foge à tendência geral do país, alcançando esta supervalorização de preços também na década de 1870 (v. Tabela 12 e ANEXO 2/Tabela 4) e o maior volume de compra/venda de escravos (61,0\%). (v. Tabela 10 e Gráfico 2)

\footnotetext{
${ }^{172}$ Cf. MOTTA, J. Flávio \& MARCONDES Renato L. Duas fontes documentais para o estudo dos preços dos escravos no Vale do Paraíba paulista. Revista Brasileira de História. São Paulo, v. 21, nº42, 2001. Estes autores apontam a importância do conjunto das fontes constituídas de escrituras de compra e venda de escravos para o estudo e análise do valor de mercado do escravo. Contudo, ressaltam que nas Listas de Classificação para Emancipação dos Escravos (do Fundo de Emancipação acima referido), verifica-se uma tendência de supervalorização no preço dos cativos arrolados (a exemplo das localidades de Lorena e Cruzeiro na Província de São Paulo, onde pesquisaram), considerando o pressuposto de que as Juntas de Classificação eram compostas por alguns dos beneficiários das indenizações que eventualmente poderiam vir deste Fundo.
} 
Os homens são os mais comprados/vendidos nas décadas de 1870 e 1880 em São Mateus, sendo que na década de 1860, eventualmente as mulheres possuem a mesma correspondência numérica. (v. Tabela 11)

Embora os homens tenham alcançado o maior valor nas décadas de 1870 e 1880 entre as médias de preços dos escravos comprados/vendidos, a valorização das mulheres, que foi maior na década de 1860, praticamente equiparou-se a estes ao final das três últimas décadas de escravidão.

Tabela 11: Média de preços de escravos comprados/vendidos por décadas em São Mateus (1863-1887).

\begin{tabular}{lcccrcrrr}
\hline Década & $\begin{array}{c}\mathrm{N}^{\circ} . \text { de } \\
\text { Escravos }\end{array}$ & $\begin{array}{c}\text { Homens } \\
\text { (em réis) }\end{array}$ & Preço Médio & Mulheres & Preço Médio & $\begin{array}{c}\text { Não se } \\
\text { sabe }\end{array}$ & Preço Médio \\
\hline 1860 & 104 & 52 & 619000 & 52 & 830619 & & - \\
1870 & 370 & 200 & 905282 & 170 & 851835 & 1 & 80000 \\
1880 & 132 & 74 & 965470 & 47 & 741481 & 10 & 1.090909 \\
Total & 606 & 326 & 829917 & 269 & 807978 & 11 & 585454
\end{tabular}

Fonte: Cartório de 1o Ofício de São Mateus.

Gráfico 3: Média de preços de escravos comprados/vendidos por décadas (em réis) e por sexo em São Mateus (1863-1887).

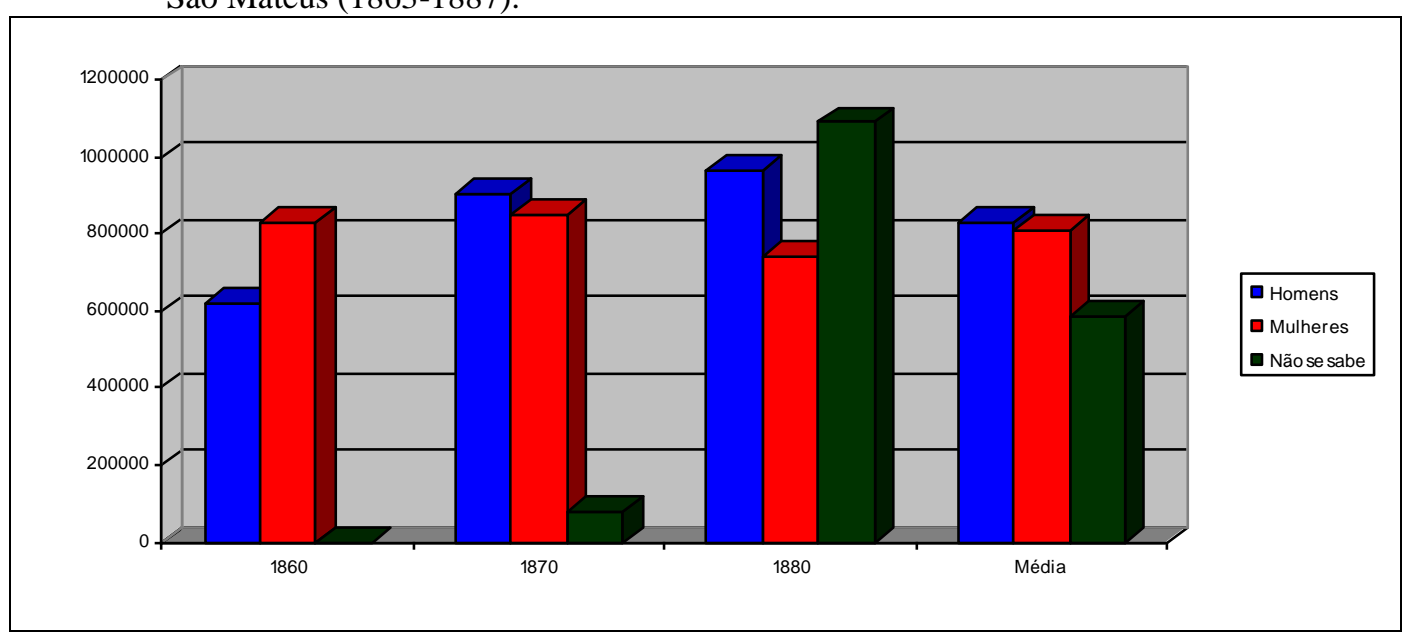

Fonte: Cartório de 1o Ofício de São Mateus.

Entre os valores médios alcançados nas compras/vendas de escravos por ano em São Mateus entre 1863 e 1887, os homens também alcançaram o maior valor no último ano integral da escravidão, em 1887 (1:275\$000 rs. - v. Tabela 12), ao passo que o valor médio das mulheres no mesmo ano é reduzido a menos da metade do valor destes (600\$000 rs.). Esta valorização é praticamente a do último ano de escravatura, sendo que para os homens foi muito elevada (haja vista a proximidade com a data de assinatura da Lei Áurea em 13 de maio de 1888, momento em que todos os escravos 
perdem definitivamente todo o seu valor econômico, implicando um prejuízo para os proprietários enquanto capital investido).

Tabela 12: Média de preços de escravos comprados/vendidos por ano em São Mateus (1863-1887).

\begin{tabular}{|c|c|c|c|c|c|c|c|}
\hline Ano & $\begin{array}{l}\mathrm{N}^{\mathrm{o}} \cdot \mathrm{de} \\
\text { Escravos }\end{array}$ & Homens & $\begin{array}{l}\text { Preço Médio } \\
\text { (em réis) }\end{array}$ & Mulheres & Preço Médio & $\begin{array}{r}\text { Não se } \\
\text { sabe }\end{array}$ & Preço Médio \\
\hline 1863 & 5 & 2 & 400000 & 3 & 1.166000 & - & - \\
\hline 1864 & 11 & 6 & 730000 & 5 & 748000 & - & - \\
\hline 1865 & 3 & 2 & 290000 & 1 & 300000 & - & - \\
\hline 1866 & 8 & 1 & 400000 & 7 & 676571 & - & - \\
\hline 1867 & 44 & 20 & 375000 & 24 & 637916 & - & - \\
\hline 1868 & 22 & 14 & 1.028500 & 8 & 1.018750 & - & - \\
\hline 1869 & 11 & 7 & 1.110000 & 4 & 1.237500 & - & - \\
\hline 1870 & 24 & 20 & 807000 & 4 & 942500 & - & - \\
\hline 1871 & 18 & 11 & 958181 & 7 & 1.007142 & 1 & 80000 \\
\hline 1872 & 32 & 17 & 1.122941 & 14 & 655714 & - & - \\
\hline 1873 & 76 & 32 & 738709 & 44 & 646363 & - & - \\
\hline 1874 & 25 & 15 & 770000 & 10 & 773000 & - & - \\
\hline 1875 & 17 & 9 & 1.006666 & 8 & 787000 & - & - \\
\hline 1876 & 39 & 20 & 421642 & 19 & 697368 & - & - \\
\hline 1877 & 44 & 28 & 1.184571 & 16 & 1.155312 & - & - \\
\hline 1878 & 27 & 13 & 919615 & 14 & 847500 & - & - \\
\hline 1879 & 69 & 35 & 1.123390 & 34 & 1.006156 & - & - \\
\hline 1880 & 23 & 16 & 1.036666 & 7 & 871428 & - & - \\
\hline 1881 & 30 & 13 & 1.030531 & 7 & 914285 & 10 & 1.090909 \\
\hline 1882 & 22 & 14 & 910714 & 8 & 1.006250 & - & - \\
\hline 1883 & 21 & 12 & 975379 & 9 & 710606 & - & - \\
\hline 1884 & 18 & 11 & 750000 & 7 & 629285 & - & - \\
\hline 1885 & 7 & 4 & 775000 & 3 & 825000 & - & - \\
\hline 1886 & 2 & - & - & 2 & 375000 & - & - \\
\hline 1887 & 5 & 2 & 1.275000 & 3 & 600000 & - & - \\
\hline Total & 606 & 326 & - & 269 & - & 11 & - \\
\hline
\end{tabular}

Fonte: Cartório de 1o Ofício de São Mateus.

Os homens são os mais comprados/vendidos, 326 escravos, enquanto as mulheres somam-se 269 ao longo do último quartel da escravidão em São Mateus. Em duas negociações envolvendo 11 escravos não se sabe o sexo destes (uma negociação em que foram comprados/vendidos 10 escravos coletivamente - em 1881 - não constando o nome de cada cativo, e em outra em que foi negociado apenas um, em 1871, constando apenas valores, nome do vendedor e do comprador dentre outras informações).

De acordo com a Tabela 12 a subida dos preços dos escravos em São Mateus se deu a partir de 1868, quando alcançou a cifra de 1:028\$500 rs. para os homens e de $1.018 \$ 750$ rs. para as mulheres, um aumento considerável visto que no ano anterior (1867), a média era de $375 \$ 000$ rs. para os homens e de $637 \$ 916$ rs. 
Em 1872, provavelmente com os efeitos da Lei do Ventre Livre em 1871, há um novo aumento dos preços para os cativos do sexo masculino e queda acentuada destes para cativos do sexo feminino em São Mateus.

A partir de então, por toda a década de 1870 e boa parte da de 1880, há uma estabilização da alta de preços, sendo que as maiores se deram em 1872, 1875, 1877 , 1879, 1880, 1881 e 1882, tanto para homens quanto para mulheres. A partir de 1883, nos últimos cinco anos de escravidão, com a pressão do movimento abolicionista houve uma tendência à queda de preços dos escravos (v. Tabela 12)

De acordo com as Tabelas 2 e 3 do ANEXO 2 (v. ANEXO 2 - Tabelas 2e 3), em 51 compras/vendas o valor foi de até $80 \$ 000$ rs; estas negociações foram realizadas nos primeiros anos dos registros, quando o preço do escravo ainda não havia se elevado tanto, sendo que a maior parte das compras/vendas foram coletivas, e uma parcela destas talvez tenha sido realizada entre uma mesma parentela. Outras negociações se destacaram, ao longo dos 25 anos (1863-1887), tais como:

- a de 1 escravo que alcançou 2:500\$000 rs.;

- a de 1 escravo que alcançou $2.160 \$ 000$ rs;

- a de 1 escravo que alcançou 2:000\$000 rs.;

- as de 22 escravos que alcançaram o valor de 1:500\$000 rs. cada um;

- as de 34 escravos que alcançaram o valor de 1:400\$000 rs. cada um;

- as de 27 escravos que alcançaram o valor de 1:300\$00 rs. cada um;

- as de 42 escravos que alcançaram o valor de 1:200\$000 rs. cada um;

- as de 20 escravos que alcançaram o valor de 1:100\$000 rs. cada um;

- a de 60 escravos que alcançaram o valor de 1:000\$000 rs. cada um;

No entanto, o fator preponderante na determinação do preço do escravo era a própria conjuntura econômica. No decorrer da segunda metade do século XIX, como qualquer outra mercadoria, o valor dos preços dos escravos sofreu grandes modificações, regulando-se pela lei da oferta e da procura.

A crescente demanda de mão-de-obra nas lavouras cafeeiras da província capixaba vai coincidir com o fim do tráfico de africanos, ocasionando uma alta dos preços. Estes dobraram na segunda metade da década de 1850 e triplicaram na década de $1860 .{ }^{173}$ Entre 1877 e 1881 os preços atingem a maior alta, e mesmo decrescendo

${ }^{173}$ ALMADA, 1984, p. 129. 
pouco ao longo da década de 1880, chega às vésperas da Abolição ainda com um valor considerável. ${ }^{174}$

Outras variáveis dos escravos negociados em São Mateus: cores, ocupação e estado conjugal.

Como no caso das alforrias, é elevado número de nada consta nas escrituras de compra e venda (35,2\% - v. Tabela 13) acerca de algumas variáveis dos escravos, reduzindo consideravelmente a amostragem para 392 documentos.

Na variável cor a preta é a predominante com 217 registros (35,8\%), seguida pela cor crioula $(11,2)$, parda $(8,8)$ e cabra $(6,6)$. Aqui, como no caso das alforrias, estas caracterizações são as mais utilizadas. Devemos fazer uma observação a respeito da expressão crioula, amplamente utilizada nos documentos de compra e venda, enquanto cor (e nunca etnia) e muito raramente denotando a origem do escravo: nestes casos o termo aparece junto a outro, como crioulo $(a)$-preto $(a)$, preto $(a)$-crioulo $(a)$, crioulo-denação; também há casos em que a palavra aparece citada duas vezes em momentos distintos do mesmo documento, indicando cor e origem (nascido no Brasil).

Os homens constituem a maioria em relação às cores preta e parda. Em relação à cor cabra há um equilíbrio entre os sexos. O interessante é que a cor mulata quase não é mencionada, apenas 1 caso para o sexo masculino e 1 para o feminino. Há uma referência à cor 'mixta' (impossível de se deduzir o que esta seja na realidade, pois só temos a referência a um caso de compra de escrava (de Araçuaí/ MG - Arassuhay no documento - no Vale do Jequitinhonha).

\footnotetext{
${ }^{174}$ Almada observa que "no Espírito Santo o preço médio de um escravo de 15 a 29 anos passa de 1.167 mil réis em 1881, para 809 mil réis em 1887, demonstrando valer, ainda na última data, $69,3 \%$ do valor alcançado em 1881". Op. cit., p.130.
} 
Tabela 13: Cores dos escravos comprados/vendidos em São Mateus (1863-1887).

\begin{tabular}{lcrrrrrrr}
\hline $\begin{array}{l}\text { Cor do } \\
\text { escravo }\end{array}$ & \multicolumn{7}{c}{ Sexo do escravo } & \\
& Homens & $\%$ & Mulheres & $\%$ & Não se sabe & $\%$ & Total & $\%$ \\
\hline Preta & 120 & 19,8 & 97 & 16,0 & - & - & 217 & 35,8 \\
Crioula & 37 & 6,2 & 31 & 5,1 & - & - & 68 & 11,2 \\
Parda & 28 & 4,6 & 25 & 4,2 & - & - & 53 & 8,8 \\
Cabra & 20 & 3,3 & 20 & 3,3 & - & - & 40 & 6,6 \\
Fula & 4 & 0,7 & 7 & 1,2 & - & - & 11 & 1,8 \\
Mulata & 1 & 0,2 & 1 & 0,2 & - & - & 2 & 0,4 \\
Cor 'mixta' & - & - & 1 & 0,2 & - & - & 1 & 0,2 \\
& & & & & - & & & \\
Nada consta & 116 & 19,1 & 87 & 14,3 & 11 & 1,8 & 214 & 35,2 \\
Total & 326 & 53,9 & 269 & 44,3 & 11 & 1,8 & 606 & 100,0 \\
\hline
\end{tabular}

Fonte: Cartório de 1ㅇ Ofício de São Mateus.

Gráfico 4: Cores dos escravos comprados/vendidos por sexo em São Mateus (1863-1887).

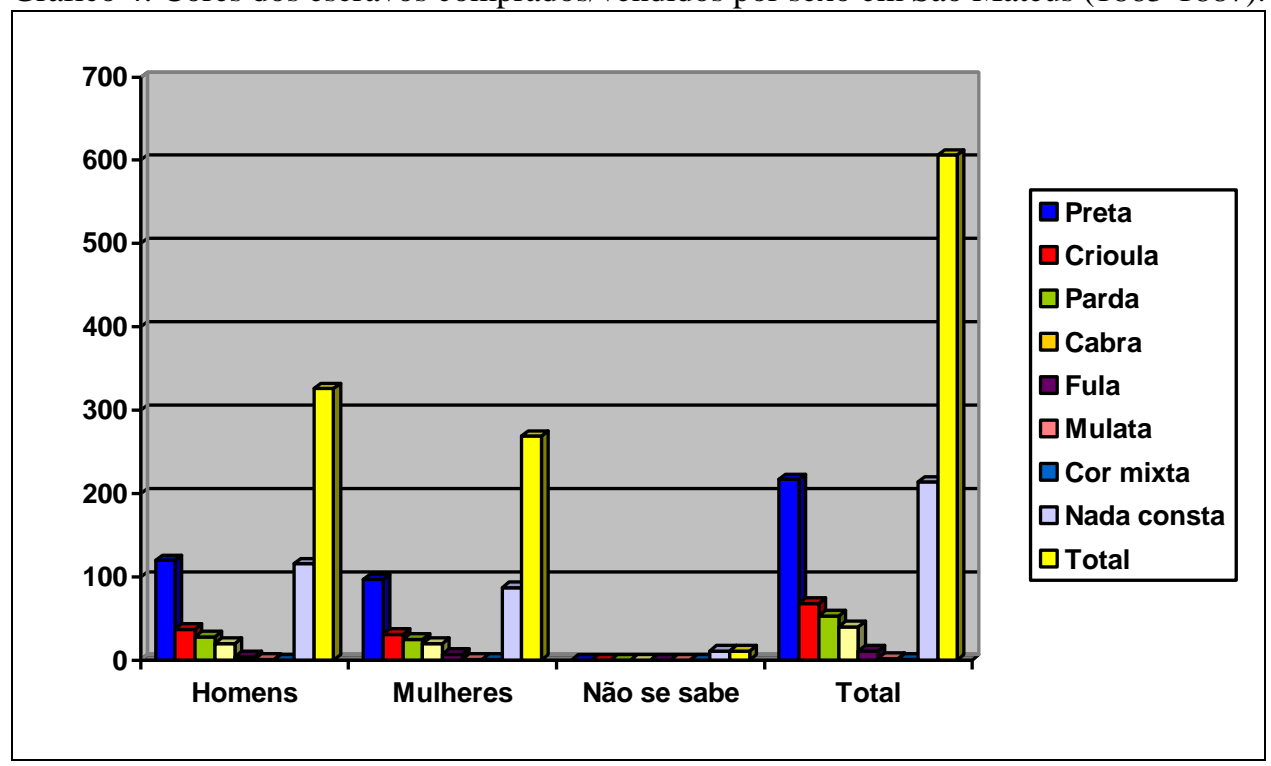

Fonte: Cartório de 1o Ofício de São Mateus.

Em relação à ocupação dos escravos comprados/vendidos em São Mateus, (v. Tabela 14) os serviços de lavoura são os mais citados (10,4\%), secundado pelos serviços domésticos (1,5\%). As especializações são variadas (costureiro, cozinheiro, carpinteiro, pedreiro, marítimo dentre outros), mas são pouco registradas. Novamente o elevado índice de nada consta (86\%), reduz a amostragem consideravelmente para 83 documentos apenas. 
Tabela 14: Ocupações dos escravos comprados/vendidos em São Mateus (1863-1887). Ocupação do Sexo do escravo

escravo

$$
\text { Homens } \% \text { Mulheres } \% \text { Não se sabe } \% \text { Total } \%
$$

\begin{tabular}{|c|c|c|c|c|c|c|c|c|}
\hline $\begin{array}{l}\text { Serviços } \\
\text { de lavoura }\end{array}$ & 34 & 5,6 & 27 & 4,4 & - & - & 61 & 10,4 \\
\hline $\begin{array}{l}\text { Serviços } \\
\text { domésticos }\end{array}$ & 2 & 0,3 & 8 & 1,3 & - & - & 10 & 1,5 \\
\hline Costureira (o) & - & - & 2 & 0,3 & - & - & 2 & 0,3 \\
\hline Cozinheira (o) & 1 & 0,2 & 1 & 0,2 & - & - & 2 & 0,3 \\
\hline Sem ofício & 1 & 0,2 & 1 & 0,2 & - & - & 2 & 0,3 \\
\hline $\begin{array}{l}\text { Apto para } \\
\text { qualquer serviço } \\
\text { ganhadeiro }\end{array}$ & 1 & 0,2 & - & - & - & - & 1 & 0,2 \\
\hline Maritimo & 1 & 0,2 & - & - & - & - & 1 & 0,2 \\
\hline Carpinteiro & 1 & 0,2 & - & - & - & - & 1 & 0,2 \\
\hline Pedreiro & 1 & 0,2 & - & - & - & - & 1 & 0,2 \\
\hline Vaqueiro & 1 & 0,2 & - & - & - & - & 1 & 0,2 \\
\hline Fiadeira & - & - & 1 & 0,2 & - & - & 1 & 0,2 \\
\hline Nada consta & 283 & 46,7 & 229 & 37,8 & 11 & 1,8 & 523 & 86,0 \\
\hline Total & 326 & 53,9 & 269 & 44,3 & 11 & 1,8 & 606 & 100,0 \\
\hline
\end{tabular}

Fonte: Cartório de 10 Ofício de São Mateus.

Gráfico 5: Ocupações dos escravos comprados/vendidos por sexo em São Mateus (1863 -1887).

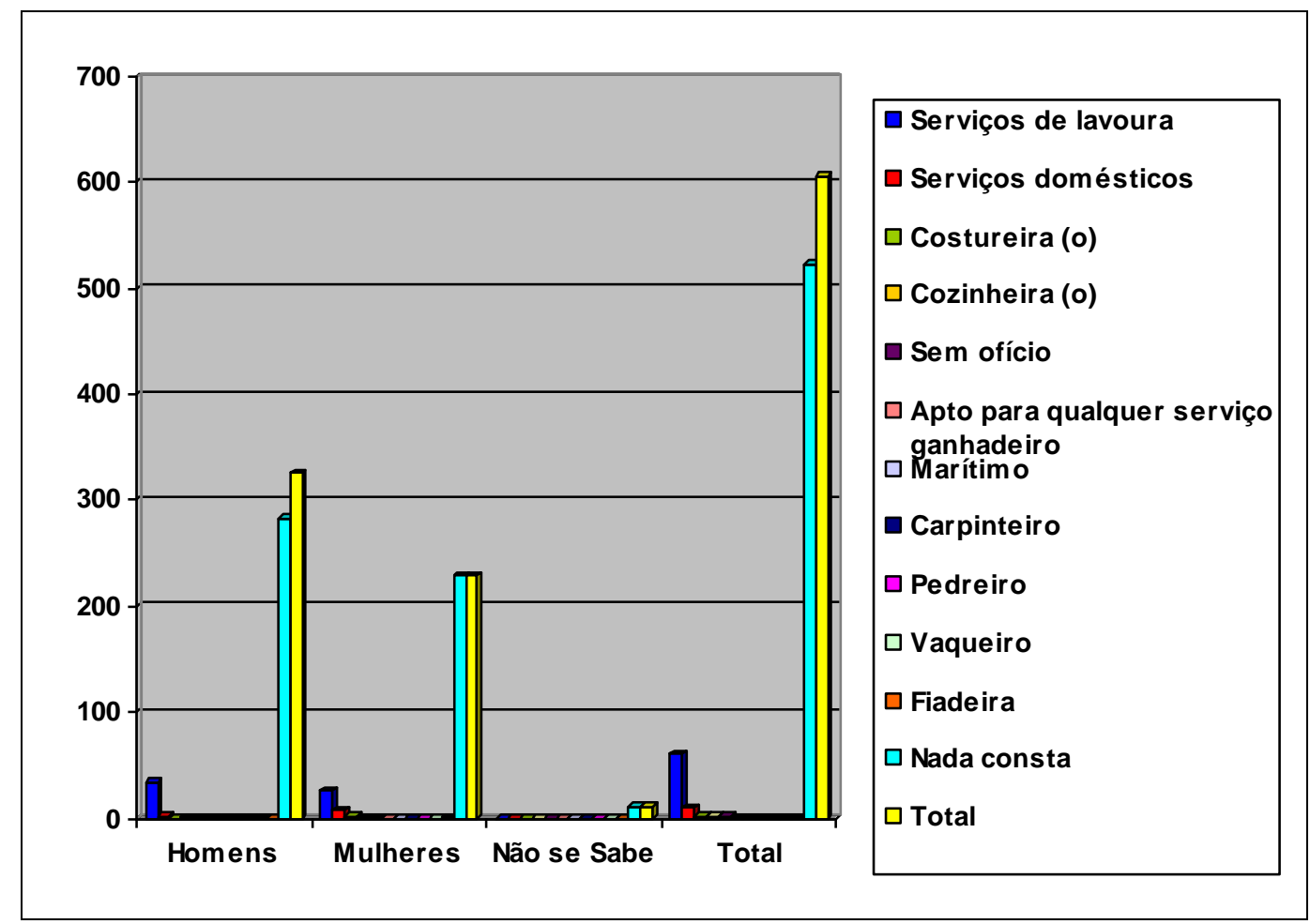

Fonte: Cartório de 1ํo Ofício de São Mateus. 
Os homens são a maioria nos serviços de lavoura (5,6\%), como já era de se esperar (v. Tabela 14); no entanto, as mulheres alcançam um número elevado nestes serviços $(4,4 \%)$. Nos serviços domésticos elas são a maioria $(1,3 \%)$ em relação aos homens $(0,3 \%)$. Nas ocupações especializadas, os homens constituem o maior número, sendo que as mulheres aparecem apenas como costureira (duas), como cozinheira (uma) e como fiadeira (uma). Nos serviços de ganho comparecem apenas um homem. Embora não obtemos maior número de registros dos serviços de ganho nas escrituras de compra/venda de escravos, pressupomos que havia muitos escravos de ganho em São Mateus no período estudado. Estes escravos são muito citados na história oral, sendo que alguns se tornaram famosos na região como quitandeiros na praça do porto.

Quanto ao estado conjugal dos escravos (v. Tabela 15) incluímos as categorias criança e adolescente para ajudar a discernir melhor as composições sociais. Os solteiros compõem a maior faixa (18,3\%), sendo que foi encontrado apenas 1 registro de casamento $(0,2 \%)$. Os 'outros' $(1,5 \%)$ são os referentes a outras formas de relações, tais como amasios e mancebias.

Tabela 15: Estado conjugal dos escravos comprados/vendidos em São Mateus (1863-1887).

\begin{tabular}{|c|c|c|c|c|c|c|c|c|}
\hline \multirow{2}{*}{$\begin{array}{l}\text { Estado } \\
\text { conjugal do } \\
\text { escravo }\end{array}$} & \multicolumn{7}{|c|}{ Sexo do escravo } & \multirow[b]{2}{*}{$\%$} \\
\hline & Homens & $\%$ & Mulheres & $\%$ & Não se sabe & $\%$ & Total & \\
\hline Solteiros & 55 & 9,1 & 56 & 9,2 & - & - & 111 & 18,3 \\
\hline Casados & 1 & 0,2 & - & - & - & - & 1 & 0,2 \\
\hline Outros & 5 & 0,8 & 4 & 0,7 & - & - & 9 & 1,5 \\
\hline Adolescentes & 8 & 1,3 & 5 & 0,8 & - & - & 13 & 2,1 \\
\hline Crianças & 16 & 2,6 & 13 & 2,1 & - & - & 29 & 4,8 \\
\hline Nada consta & 241 & 39,7 & 191 & 31,5 & 11 & 1,8 & 443 & 73,1 \\
\hline Total & 326 & 53,9 & 269 & 44,3 & 11 & 1,8 & 606 & 100,0 \\
\hline
\end{tabular}


Gráfico 6: Estado conjugal dos escravos comprados/vendidos em São Mateus (1863-1887).

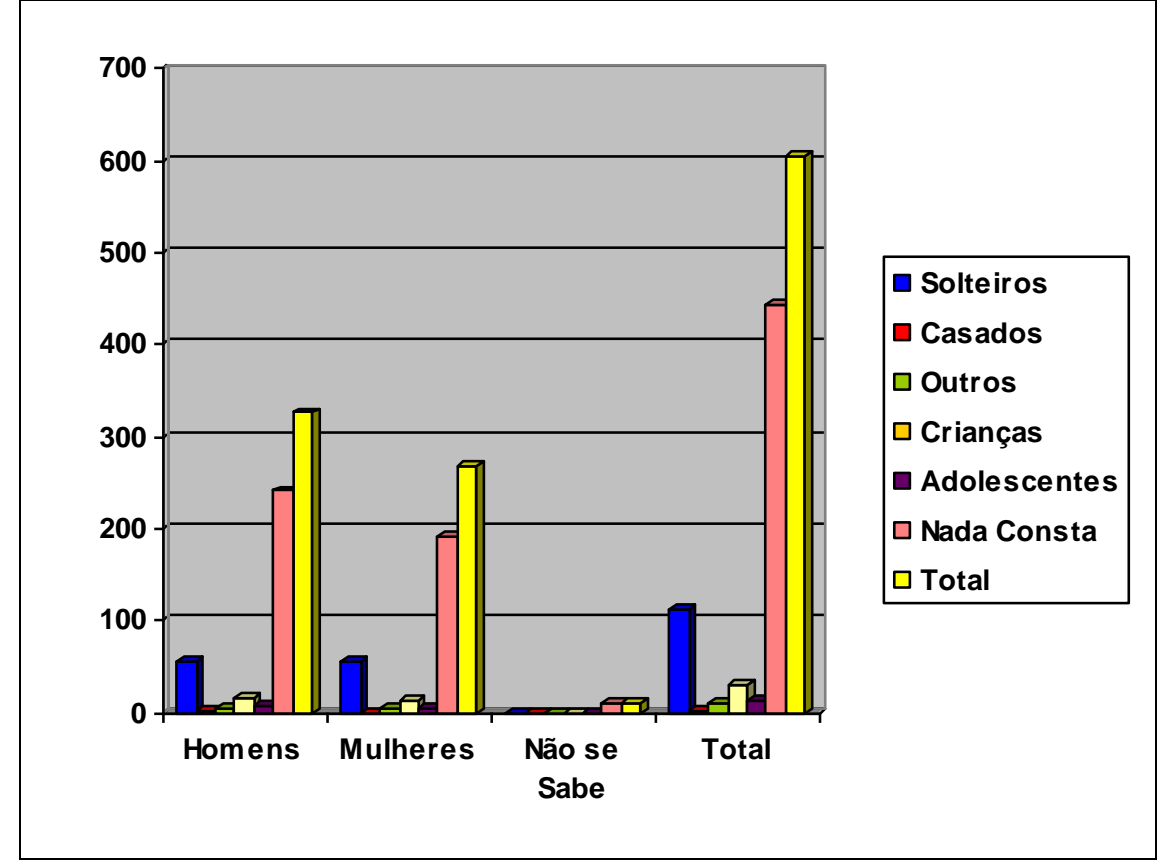

Fonte: Cartório de 1o Ofício de São Mateus.

Embora seja também elevadíssimo o índice de nada consta (v. Gráfico 6) acerca do estado conjugal do escravo $(73,1 \%)$, reduzindo a amostragem para apenas 163 escravos, podemos verificar o equilíbrio entre o número de homens solteiros $(9,1 \%)$ e mulheres solteiras $(9,2 \%)$. Nos dados obtidos verificamos o casamento de apenas um homem. Entre as crianças podemos considerar que também há um relativo equilíbrio entre os sexos.

Acerca da procedência dos escravos negociados em São Mateus.

Embora o mercado de escravos em São Mateus, da segunda metade do século XIX, fosse um mercado de cunho local, em que a maior parte dos escravos objeto de compra e venda residia e trabalhava na própria região, não podemos desconsiderar a variedade de locais de sua procedência. (v. Tabela 16) 
Tabela 16: Origem/procedência dos escravos comprados/vendidos em São Mateus (1863-1887).

\begin{tabular}{|c|c|c|c|c|c|}
\hline \multirow{2}{*}{$\begin{array}{l}\text { Origem/pro- } \\
\text { cedência } \\
\text { do escravo }\end{array}$} & \multirow[b]{2}{*}{ Homens } & \multicolumn{2}{|c|}{ Sexo do escravo } & \multirow[t]{2}{*}{ Total } & \multirow[t]{2}{*}{$\%$} \\
\hline & & Mulheres & Não se sabe & & \\
\hline Província do Espírito Santo & - & - & - & - & - \\
\hline São Mateus & 73 & 122 & - & 195 & 32,2 \\
\hline Vila da Barra & 25 & 17 & - & 42 & 6,9 \\
\hline Serra & 1 & - & - & 1 & 0,2 \\
\hline Vitória & 4 & 9 & - & 13 & 2,1 \\
\hline Linhares & 4 & 1 & - & 5 & 0,8 \\
\hline Viana & 2 & 1 & - & 3 & 0,5 \\
\hline Município de São Raymundo & - & - & - & - & 0,0 \\
\hline Total & 109 & 150 & - & 259 & 42,7 \\
\hline Província da Bahia & 6 & 10 & 1 & 17 & 2,8 \\
\hline Caravelas & 1 & - & - & 1 & 0,2 \\
\hline Alcobaça & - & 2 & - & 2 & 0,3 \\
\hline Total & 7 & 12 & 1 & 20 & 3,3 \\
\hline Província de Minas Gerais & 7 & 13 & - & 20 & 3,3 \\
\hline Minas Novas/Araçuaí & 10 & 17 & - & 27 & 4,5 \\
\hline Filadélfia & - & 4 & - & 4 & 0,7 \\
\hline Total & 17 & 34 & - & 51 & 8,6 \\
\hline Rio de Janeiro & 12 & 8 & - & 20 & 3,3 \\
\hline Município Neutro & - & 1 & - & 1 & 0,2 \\
\hline Total & 12 & 9 & - & 21 & 3,6 \\
\hline Africanos & 14 & 9 & - & 23 & 3,8 \\
\hline Nada consta & 167 & 55 & 10 & 232 & 38,3 \\
\hline Total Geral & 326 & 269 & 11 & 606 & 100,0 \\
\hline
\end{tabular}

Fonte: Cartório de 1o Ofício de São Mateus. 
Gráfico 7: Origem/procedência dos escravos comprados/vendidos em São Mateus (1863-1887).

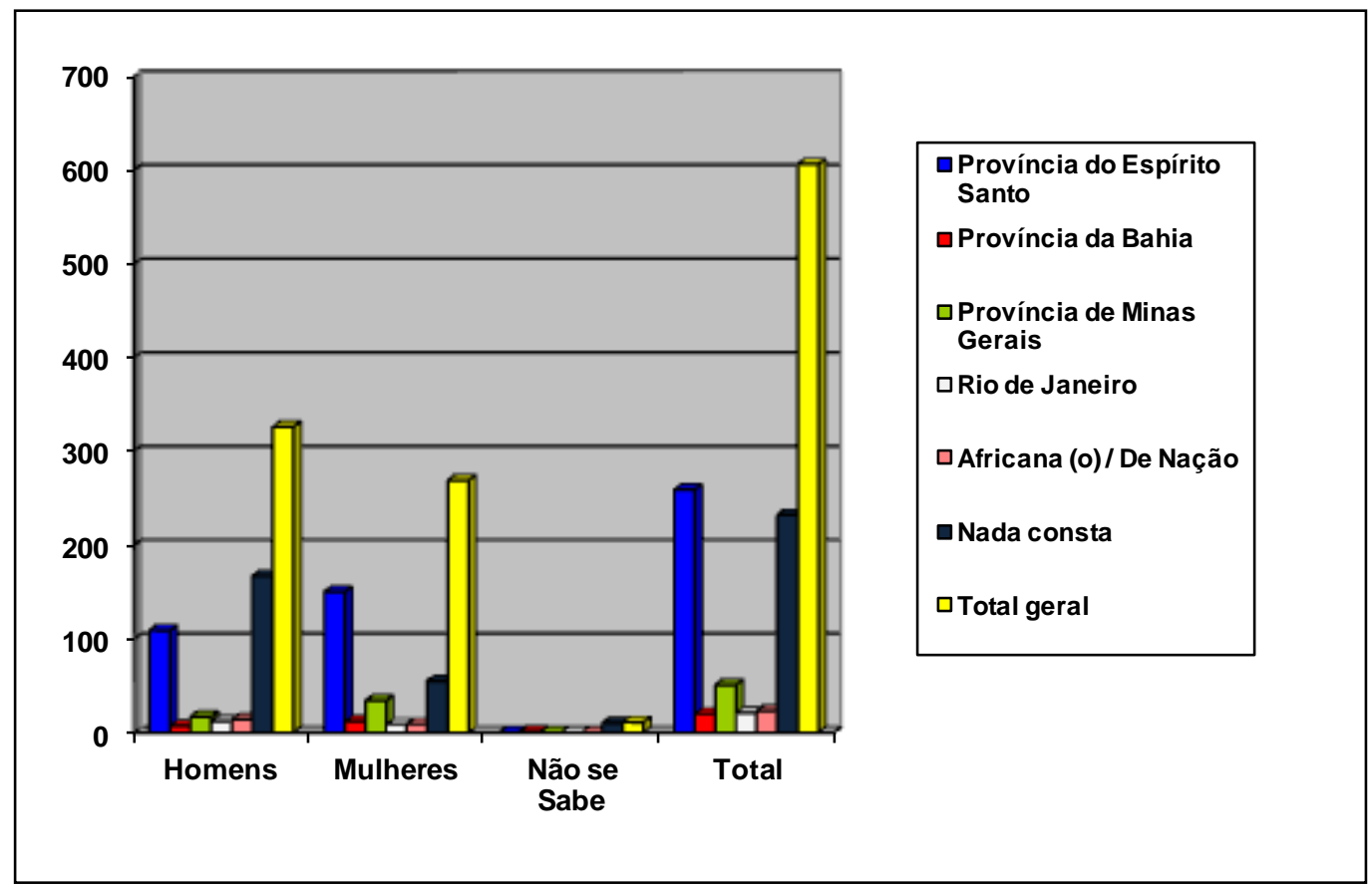

Fonte: Cartório de 1o Ofício de São Mateus.

Com base nos dados da Tabela 16, podemos afirmar que a maior parte dos escravos negociados na Freguesia de São Mateus (v. Tabela 16 e Gráfico 7) era formada por indivíduos nascidos e criados nesta região ou em suas circunvizinhanças, sendo 195 do município de São Mateus (32,2\%) e 42 da Vila da Barra (6,9\%), totalizando-se 237 destes $(39,1 \%)$ para o conjunto dos 606 escravos. De todo o Espírito Santo somam-se 259 escravos, vindo apenas 22 escravos de outras regiões da província.

Entre os restantes, 51 escravos são procedentes da Província de Minas Gerais (especificando-se apenas Filadélfia/4 escravos e Minas Novas/27 escravos), o que é um número significativo, mais que o dobro da Província da Bahia (20 escravos, especificando-se apenas Caravelas/1 escravo e Alcobaça/2 escravos). Filadélfia e Minas Novas juntas forneceram um montante de 31 escravos, o que corrobora mais uma vez a ligação comercial de São Mateus com essas regiões via rio Mucuri e rio Doce.

Os escravos oriundos da Corte (Rio de Janeiro/ Município Neutro) somam-se 21, enquanto os escravos africanos/de nação somam-se 23 (havendo algumas, poucas, referências a angolanos e de nação nagô). 
Em 232 compras/vendas nada foi constatado a respeito da procedência do escravo, revelando assim o elevado índice $(38,3 \%)$ de ausência dessa importante variável nos documentos de compra e venda.

Embora a presença de traficantes de escravos, corsários e outros clandestinos no porto da Barra de São Mateus antes e depois da abolição do tráfico externo, seja muito relatada através da história oral e da literatura local, podemos afirmar que a entrada de africanos na região, mesmo vindos legalmente de outras partes do Brasil, não teve peso significativo na segunda metade do século XIX. Neste período esta entrada $(3,8 \%)$ provavelmente reduzida em relação ao período anterior à proibição em 1850 - não foi expressiva, embora mantendo-se mais elevada que os oriundos da Província da Bahia $(3,3 \%)$ e do Rio de Janeiro $(3,6 \%)$.

\subsubsection{Firmas comercializadoras de escravos.}

Entre os compradores/vendedores de escravos não constam apenas indivíduos particulares, mas também empresas especializadas na compra/venda de escravos. A partir de 1863, têm-se o registro de 15 destas firmas atuando no mercado de São Mateus. São elas:

1 - Alves, Ferreira \& Cia;

2 - Faria \& Bastos;

3 - Fonseca, Rios \& Cia;

4 - Fundão \& Irmãos;

5 - Faria, Cunha \& Cia;

6 - Fundão Júnior \& Cia;

7 - Guimarães, Gaiato \& Cia;

8 - José Joaquim Almeida Fundão \& Cia;

9 - Leonel Joaquim de Almeida Fundão \& Cia;

10 - Luis José dos Santos Guimarães \& Cia;

11 - Morgado, Rios, Guimarães \& Cia;

12 - Rios \& Cia;

13 - Veiga \& Cia;

14 - Simões, Faria \& Cia; e

15 - Joaquim Lopes \& Irmão.

Entre estas, ao que nos foi possível averiguar, a Faria, Cunha \& Cia é uma das primeiras firmas comercializadoras de produtos agrícolas e escravos da região, que, embora sediada no Rio de Janeiro, tinha como espaço de atuação o porto de São Mateus. Esta firma era composta pelos sócios Manoel José de Faria e Reginaldo Gomes 
da Cunha, respectivamente, irmão e cunhado de Antonio Rodrigues da Cunha/ Barão de Aimorés. ${ }^{175}$ Desde fins da década de 1840, segundo relatos, toda a produção de farinha de mandioca da Fazenda São Domingos (situada à margem do rio São Domingos, afluente do São Mateus) de propriedade do comendador Antonio Rodrigues da Cunha e de dona Rita Cunha, pais de Aimorés, seria exportada em barcos à vela, de propriedade da fazenda para a firma Faria, Cunha \& Cia, estabelecida no Rio de Janeiro.

Tabela 17: Sexo do comprador e firmas compradoras de escravos em São Mateus

\begin{tabular}{|c|c|c|c|}
\hline $\begin{array}{l}\text { Sexo do comprador/ } \\
\text { firmas compradoras }\end{array}$ & Frequência & Percentual & Percentual Acumulado \\
\hline Homens & 167 & 87,0 & 87,0 \\
\hline Mulheres & 18 & 9,5 & 96,4 \\
\hline Joaquim de & & & \\
\hline Almeida Fundão \& Cia & 1 & 0,5 & 96,9 \\
\hline Faria \& Bastos & 1 & 0,5 & 97,4 \\
\hline Fonseca, Rios \& Cia & 1 & 0,5 & 97,9 \\
\hline Faria, Cunha \& Cia & 1 & 0,5 & 98,4 \\
\hline Fundão, Júnior \& Cia & 1 & 0,5 & 99,0 \\
\hline Guimarães, Gaiato \& Cia & 1 & 0,5 & 99,5 \\
\hline José Joaquim de Almeida & & & \\
\hline Fundão \& Cia & 1 & 0,5 & 100,0 \\
\hline Total & 192 & 100,0 & - \\
\hline
\end{tabular}

Fonte: Cartório de 1o Ofício de São Mateus.

Numericamente as firmas compradoras (v. Tabela 17) são poucas (7 ao todo) em relação ao número de indivíduos compradores de escravos (167 homens e 18 mulheres), correspondendo apenas a 3,5\% do total de compradores. Entre as 15 firmas registradas nas escrituras de compra/venda de escravos, 7 aparecem como compradoras e 8 como vendedoras. Apenas 3 firmas, a Faria \& Bastos, a Faria, Cunha \& Cia e a Fundão, Júnior \& Cia, figuraram entre os compradores e os vendedores, ou seja, realizaram negociações de compras/vendas de escravos. Não há registro de compra/venda de escravos de uma firma para outra.

Entre os vendedores de escravos (v. Tabela 18), somam-se 204 homens $(76,1 \%)$ 42 mulheres $(15,7 \%), 14$ sócios $(5,2 \%)$ e 8 firmas, as quais correspondem a apenas $3,2 \%$ do total de vendedores.

${ }^{175}$ JORNAL DE SÃO MATEUS, $n^{\circ}$. 465, de 20/09/2001. 
Tabela 18: Sexo do vendedor/ firmas vendedoras de escravos em São

Mateus (1863-1887).

\begin{tabular}{lccc}
\hline $\begin{array}{l}\text { Sexo do vendedor/ } \\
\text { Firmas vendedoras }\end{array}$ & Frequência & Percentual & Percentual Acumulado \\
\hline Homens & 204 & 76,1 & 76,1 \\
Mulheres & 42 & 15,7 & 91,8 \\
Sócios & 14 & 5,2 & 97,0 \\
& & & \\
Alves, Ferreira \& Cia & 1 & 0,4 & 97,4 \\
Faria \& Bastos & 1 & 0,4 & 97,8 \\
Fundão \& Irmãos & 1 & 0,4 & 98,1 \\
Faria, Cunha \& Cia & 1 & 0,4 & 98,5 \\
Luis José dos Santos & 1 & 0,4 & 98,9 \\
Guimarães \& Cia & & & \\
Morgado, Rios, & 1 & 0,4 & 99,3 \\
Guimarães \& Cia & & & 9,4 \\
Rios \& Cia & 1 & 0,4 & 100,0 \\
Veiga \& Cia & 1 & 0,4 & - \\
& & & \\
Total & 268 & 100,0 & \\
\hline
\end{tabular}

Fonte: Cartório de 1o Ofício de São Mateus.

Em relação ao número de escravos comprados pelas firmas (v. Tabela 19), a maior compra é a de 14 escravos realizada pela firma Leonel Joaquim de Almeida Fundão \& Cia. A firma Guimarães, Gaiato \& Cia compra 3 escravos e a Fonseca, Rios \& Cia compra 2 escravos. As outras 4 firmas compradoras de escravos só compraram 1 escravo por vez em suas negociações.

Tabela 19: Número de escravos comprados por sexo do comprador/firmas compradoras em São Mateus

\begin{tabular}{|c|c|c|c|c|c|c|c|c|c|c|}
\hline \multirow{2}{*}{$\begin{array}{l}\text { Número } \\
\text { de } \\
\text { escravos } \\
\text { comprados }\end{array}$} & \multicolumn{9}{|c|}{ Sexo do comprador/firmas compradoras } & \multirow[t]{2}{*}{ Total } \\
\hline & $\mathrm{H}$ & M & $\begin{array}{l}\text { Leonel } \\
\text { Joaquim } \\
\text { de } \\
\text { Almeida } \\
\text { Fundão } \\
\text { \& Cia }\end{array}$ & $\begin{array}{r}\text { Faria } \\
\& \\
\text { Bastos }\end{array}$ & $\begin{array}{l}\text { Fonseca, } \\
\text { Rios } \\
\text { \&Cia }\end{array}$ & $\begin{array}{l}\text { Faria, } \\
\text { Cunha } \\
\& \\
\text { Júnior }\end{array}$ & $\begin{array}{c}\text { Fundão, } \\
\text { Júnior \& } \\
\text { Cia }\end{array}$ & $\begin{array}{c}\text { Guimarães, } \\
\text { Gaiato } \\
\text { \& Cia }\end{array}$ & $\begin{array}{r}\text { José } \\
\text { Joaquim } \\
\text { de } \\
\text { Almeida } \\
\text { Fundão } \\
\text { \& Cia }\end{array}$ & \\
\hline 1 & 77 & 14 & - & 1 & - & 1 & 1 & - & 1 & 95 \\
\hline 2 & 32 & 1 & - & - & 1 & - & - & - & - & 34 \\
\hline 3 & 17 & 2 & - & - & - & - & - & 1 & - & 20 \\
\hline 4 & 10 & - & - & - & - & - & - & - & - & 10 \\
\hline 5 & 10 & 1 & - & - & - & - & - & - & - & 11 \\
\hline 6 & 8 & - & - & - & - & - & - & - & - & 8 \\
\hline 7 & 1 & - & - & - & - & - & - & - & - & 1 \\
\hline 8 & 2 & - & - & - & - & - & - & - & - & 2 \\
\hline 10 & 1 & - & - & - & - & - & - & - & - & 1 \\
\hline 14 & 3 & - & 1 & - & - & - & - & - & - & 4 \\
\hline 15 & 1 & - & - & - & - & - & - & - & - & 1 \\
\hline 17 & 1 & - & - & - & - & - & - & - & - & 1 \\
\hline 18 & 1 & - & - & - & - & - & - & - & - & 1 \\
\hline
\end{tabular}




\begin{tabular}{ccccccccccc}
27 & 1 & - & - & - & - & - & - & - & - & 1 \\
29 & 1 & - & - & - & - & - & - & - & - & 1 \\
45 & 1 & - & - & - & - & - & - & - & - & 1 \\
Total & 167 & 18 & 1 & 1 & 1 & 1 & 1 & 1 & 1 & 192 \\
\hline
\end{tabular}

O mesmo ocorre entre o número de escravos vendidos pelas 8 firmas comercializadoras (v. Tabela 20), ou seja, apenas 1 firma negociou um número maior de escravos: a Faria \& Bastos que vendeu 24 escravos em uma só transação. As outras 7 firmas restantes venderam apenas 1 escravo por negociação.

Tabela 20: Número de escravos vendidos por sexo do vendedor/ firmas compradoras em São Mateus

\begin{tabular}{|c|c|c|c|c|c|c|c|c|c|c|c|c|}
\hline \multirow{2}{*}{$\begin{array}{l}\text { Número } \\
\text { de } \\
\text { escravos } \\
\text { vendidos }\end{array}$} & \multirow[b]{2}{*}{$\mathrm{H}$} & \multirow[b]{2}{*}{ M } & \multirow[b]{2}{*}{ Sócios } & \multicolumn{4}{|c|}{ Sexo do vendedor } & \multirow[b]{2}{*}{$\begin{array}{c}\text { Luis José } \\
\text { dos Santos } \\
\text { Guimarães } \\
\text { \& Cia }\end{array}$} & \multirow[b]{2}{*}{$\begin{array}{c}\text { Morgado, } \\
\text { Rios, } \\
\text { Guimarães } \\
\text { \& Cia }\end{array}$} & \multirow[b]{2}{*}{$\begin{array}{c}\text { Rios } \\
\& \\
\text { Cia }\end{array}$} & \multirow[b]{2}{*}{$\begin{array}{c}\text { Veiga } \\
\& \\
\text { Cia }\end{array}$} & \multirow[t]{2}{*}{ Tota } \\
\hline & & & & $\begin{array}{r}\text { Alves, } \\
\text { Ferreia } \\
\& \text { Cia }\end{array}$ & $\begin{array}{r}\text { Faria } \\
\& \\
\text { Bastos }\end{array}$ & $\begin{array}{r}\text { Fundão } \\
\& \\
\text { Irmãos }\end{array}$ & $\begin{array}{l}\text { Faria, } \\
\text { Cunha } \\
\& \text { Cia }\end{array}$ & & & & & \\
\hline 1 & 121 & 31 & 9 & 1 & - & 1 & 1 & 1 & 1 & 1 & 1 & 168 \\
\hline 2 & 33 & 3 & 3 & - & - & - & - & - & - & - & - & 39 \\
\hline 3 & 16 & 3 & 1 & - & - & - & - & - & - & - & - & 20 \\
\hline 4 & 12 & 3 & - & - & - & - & - & - & - & - & - & 15 \\
\hline 5 & 7 & 1 & - & - & - & - & - & - & - & - & - & 8 \\
\hline 6 & 5 & - & - & - & - & - & - & - & - & - & - & 5 \\
\hline 7 & 3 & - & - & - & - & - & - & - & - & - & - & 3 \\
\hline 8 & 1 & - & - & - & - & - & - & - & - & - & - & 1 \\
\hline 9 & 1 & - & - & - & - & - & - & - & - & - & - & 1 \\
\hline 11 & 2 & - & 1 & - & - & - & - & - & - & - & - & 3 \\
\hline 12 & 1 & - & - & - & - & - & - & - & - & - & - & 1 \\
\hline 14 & 1 & - & - & - & - & - & - & - & - & - & - & 1 \\
\hline 23 & - & 1 & - & - & - & - & - & - & - & - & - & 1 \\
\hline 24 & - & - & - & - & 1 & - & - & - & - & - & - & 1 \\
\hline 26 & 1 & - & - & - & - & - & - & - & - & - & - & 1 \\
\hline Total & 204 & 42 & 14 & 1 & 1 & 1 & 1 & 1 & 1 & 1 & 1 & 268 \\
\hline
\end{tabular}

Fonte: Cartório de 1ㅇ. Ofício de São Mateus.

A década de 1870 foi a que mais registrou negociações de compras de escravos em São Mateus, como podemos observar pela Tabela 21. Os homens foram os que mais compraram escravos nesta década e também no período estudado (1863-1887), configurando-se em 167 compradores. As mulheres compradoras de escravos somamse 18 representando um percentual de apenas 9,3\% do total. As 7 firmas realizaram compras durante onze anos apenas, entre 1869 e 1880, não demonstrando maior expressividade numérica nestas negociações. 
Tabela 21: Ano do registro da compra e sexo do comprador/ firmas compradoras de escravos em São Mateus (1863-1887).

\begin{tabular}{|c|c|c|c|c|c|c|c|c|c|c|}
\hline \multirow[t]{2}{*}{ Ano } & \multicolumn{9}{|c|}{ Sexo do comprador/ firmas compradoras } & \multirow[t]{2}{*}{ Total } \\
\hline & Homens & Mulheres & $\begin{array}{l}\text { Leonel } \\
\text { Joaquim } \\
\text { de } \\
\text { Almeida } \\
\text { Fundão } \\
\text { Cia }\end{array}$ & $\begin{array}{l}\text { Faria } \\
\& \\
\text { Bastos }\end{array}$ & $\begin{array}{l}\text { Fonseca, } \\
\text { Rios \& } \\
\text { Cia }\end{array}$ & $\begin{array}{l}\text { Faria, } \\
\text { Cunha } \\
\text { \&Júnior }\end{array}$ & $\begin{array}{l}\text { Fundão, } \\
\text { Júnior \& } \\
\text { Cia }\end{array}$ & $\begin{array}{c}\text { Guimarães, } \\
\text { Gaiato } \\
\text { \& Cia }\end{array}$ & $\begin{array}{l}\text { José Joaquim } \\
\text { de Almeida } \\
\text { Fundão \& Cia }\end{array}$ & \\
\hline 1863 & 4 & - & - & - & - & - & - & - & - & 4 \\
\hline 1865 & 2 & - & - & - & - & - & - & - & - & 2 \\
\hline 1866 & 3 & - & - & - & - & - & - & - & - & 3 \\
\hline 1867 & 13 & 1 & - & - & - & - & - & - & - & 14 \\
\hline 1868 & 10 & 1 & - & - & - & - & - & - & - & 11 \\
\hline 1869 & 3 & 1 & - & 1 & - & - & - & 1 & - & 6 \\
\hline 1870 & 9 & 1 & - & - & - & - & 1 & - & - & 11 \\
\hline 1871 & 10 & 1 & - & - & - & - & - & - & - & 11 \\
\hline 1872 & 9 & 3 & - & - & - & - & - & - & - & 12 \\
\hline 1873 & 16 & 1 & - & - & - & - & - & - & - & 17 \\
\hline 1874 & 10 & - & - & - & - & - & - & - & - & 10 \\
\hline 1875 & 4 & - & - & - & - & - & - & - & - & 4 \\
\hline 1876 & 16 & 2 & - & - & - & 1 & - & - & - & 19 \\
\hline 1877 & 12 & 1 & - & - & - & - & - & - & - & 13 \\
\hline 1878 & 8 & 1 & - & - & - & - & - & - & - & 9 \\
\hline 1879 & 14 & 2 & 1 & - & - & - & - & - & - & 17 \\
\hline 1880 & 1 & - & - & - & - & - & - & - & 1 & 2 \\
\hline 1881 & 5 & 1 & - & - & - & - & - & - & - & 6 \\
\hline 1882 & 5 & 2 & - & - & - & - & - & - & - & 7 \\
\hline 1883 & 4 & - & - & - & - & - & - & - & - & 4 \\
\hline 1884 & 4 & - & - & - & - & - & - & - & - & 4 \\
\hline 1885 & 3 & - & - & - & - & - & - & - & - & 3 \\
\hline 1886 & 1 & - & - & - & - & - & - & - & - & 1 \\
\hline 1887 & 1 & - & - & - & - & - & - & - & - & 1 \\
\hline Total & 167 & 18 & 1 & 1 & 1 & 1 & 1 & 1 & 1 & 192 \\
\hline
\end{tabular}

Fonte: Cartório de 10 Ofício de São Mateus.

O mesmo ocorre com as vendas: as 8 firmas vendedoras de escravos embora atuam no mercado por um período mais longo (entre 1864 e 1885 - v. Tabela 22), realizaram negociações esporádicas não denotando maiores impactos no comércio regional. Os vendedores do sexo masculino predominam nas negociações, perfazendo um total de 203 elementos, enquanto as 42 mulheres têm uma atuação maior que nas compras representando um percentual de 15,7 dos vendedores de escravos. A categoria de sócios nas vendas tem sua representatividade (15 vendedores), não figurando nas compras. A década de 1870 é a que também mais registra negociações de vendas. 
Tabela 22: Ano do registro da venda e sexo do vendedor/ firmas vendedoras de escravos em São Mateus (1863-1887).

\begin{tabular}{|c|c|c|c|c|c|c|c|c|c|c|c|c|}
\hline \multirow[t]{2}{*}{ Ano } & \multicolumn{11}{|c|}{ Sexo do vendedor/firmas vendedoras } & \multirow[t]{2}{*}{ Total } \\
\hline & $\mathrm{H}$ & $\mathrm{M}$ & Sócios & $\begin{array}{c}\text { Alves, } \\
\text { Ferreira } \\
\text { \& Cia }\end{array}$ & $\begin{array}{l}\text { ria } \\
\text { astos }\end{array}$ & $\begin{array}{l}\text { \& Fundão } \\
\& \text { Irmãos }\end{array}$ & $\begin{array}{l}\text { Faria, } \\
\text { Cunha } \\
\& \text { Cia }\end{array}$ & $\begin{array}{l}\text { Luis José } \\
\text { dos Santos } \\
\text { Guimarães } \\
\text { \& Cia }\end{array}$ & $\begin{array}{l}\text { Morgado, } \\
\text { Rios, } \\
\text { Guimarães } \\
\text { \& Cia }\end{array}$ & $\begin{array}{l}\text { Rios } \\
\text { \& Cia }\end{array}$ & $\begin{array}{l}\text { Veiga } \\
\& C i a\end{array}$ & \\
\hline 1863 & 2 & 1 & 1 & - & - & - & - & - & - & - & - & 4 \\
\hline 1864 & 3 & - & - & - & - & - & - & - & - & - & 1 & 4 \\
\hline 1866 & 3 & - & - & - & - & - & - & - & - & - & - & 3 \\
\hline 1867 & 14 & 6 & - & - & - & - & - & - & 1 & 1 & - & 22 \\
\hline 1868 & 8 & - & 1 & - & - & - & - & - & - & - & - & 9 \\
\hline 1869 & 5 & - & 1 & - & - & - & - & 1 & - & - & - & 7 \\
\hline 1870 & 9 & 6 & - & - & - & - & - & - & - & - & - & 15 \\
\hline 1871 & 5 & 2 & 1 & - & - & - & - & - & - & - & 1 & 9 \\
\hline 1872 & 11 & 2 & - & - & 1 & - & - & - & - & - & - & 14 \\
\hline 1873 & 40 & 4 & 2 & - & - & - & - & - & - & - & - & 45 \\
\hline 1874 & 6 & 2 & 1 & - & - & - & - & - & - & - & - & 10 \\
\hline 1875 & 7 & 1 & - & - & - & 1 & - & - & - & - & - & 8 \\
\hline 1876 & 4 & 2 & 1 & - & - & - & - & - & - & - & - & 7 \\
\hline 1877 & 9 & 1 & 2 & - & - & - & - & - & - & - & - & 12 \\
\hline 1878 & 8 & 2 & - & - & - & - & - & - & - & - & - & 10 \\
\hline 1879 & 29 & 1 & 2 & 1 & - & - & - & - & - & - & - & 33 \\
\hline 1880 & 8 & - & - & - & - & - & - & - & - & - & - & 8 \\
\hline 1881 & 4 & 3 & 1 & - & - & - & - & - & - & - & - & 8 \\
\hline 1882 & 3 & 3 & 1 & - & - & - & - & - & - & - & - & 7 \\
\hline 1883 & 9 & 6 & - & - & - & - & - & - & - & - & - & 15 \\
\hline 1884 & 9 & - & - & - & - & - & - & - & - & - & - & 9 \\
\hline 1885 & 2 & - & - & - & - & - & 1 & - & - & - & - & 3 \\
\hline 1887 & 4 & - & - & - & - & - & - & - & - & - & - & 4 \\
\hline 1887 & 1 & - & 1 & - & - & - & - & - & - & - & - & 2 \\
\hline Total & 203 & 42 & 15 & 1 & 1 & 1 & 1 & 1 & 1 & 1 & 1 & 268 \\
\hline
\end{tabular}

Fonte: Cartório de 10 Ofício de São Mateus.

\subsection{Atividades mercantis com escravos.}

Nos estudos que analisam o tema em foco, percebe-se que desde o período colonial foi prática usual na sociedade brasileira o empenho dos escravos para contrair ou saldar dívidas, cujas evidências são apontadas principalmente nas pesquisas realizadas em inventários e na documentação cartorial, onde geralmente são encontradas referências à penhora e hipoteca de escravos como garantia ao pagamento das dívidas. Ou seja, em contextos em que a terra era barata, o escravo surgia como o bem mais valioso no qual investir, pois, dentre outros fatores, constituía-se na principal via de acesso ao crédito: "o escravo se metamorfoseava em crédito". ${ }^{176}$

\footnotetext{
${ }^{176}$ Cf. MATHIAS, Carlos Leonardo Kelmer. O movimento do crédito: o papel dos escravos nas relações de crédito, Rio de Janeiro e Minas Gerais (c. 1711 - c. 1756). In: Revista de História Regional 13(2): 46-
} 
E, não somente os mais pobres penhoravam seus escravos para contrair empréstimos, já que praticamente todas as faixas de fortunas valeram-se da penhora de escravos como garantia da solvência de suas dívidas. Conforme destacado por Mathias no estudo referente a Minas Gerais no Setecentos ${ }^{177}$, no total dos bens penhorados nos inventários post-mortem por ele pesquisados, $62,1 \%$ correspondiam aos escravos, ressaltando ainda que a participação dos escravos no valor total dos penhores era ainda mais significativa haja vista que dos 10:300\$000 rs. reunidos em penhor, os escravos corresponderam por $77,97 \%$ dessa quantia. Neste sentido, o autor constata que o escravo era o principal bem a garantir a solvência dos empréstimos contraídos pela sociedade mineira no período colonial, viabilizando aos negociantes diretamente envolvidos com as atividades do tráfico (interno e externo) condições privilegiadas de acumulação no bojo desses circuitos mercantis à época.

Tais situações, com as devidas adaptações ao contexto histórico, permaneceram recorrentes também no transcurso do Oitocentos, haja vista que vários estudos sobre riqueza e renda no Brasil da segunda metade do século XIX demonstraram que os escravos representavam uma parcela significativa da fortuna pessoal, sendo que, embora com algumas variações conforme o tempo e o lugar, em geral estes compunham cerca de $30 \%$ do patrimônio das pessoas abastadas. Não desconsiderando que a parcela da riqueza aplicada em escravos tinha um nível e liquidez muito maiores que outras formas de alocação da riqueza, como terras e equipamentos. Além do que, "parte das transações com escravos realizava-se por intermédio de crédito, possibilitado pela alta liquidez representada pelos cativos, especialmente em comparação com outros ativos não financeiros, e pela relativa estabilidade dos preços dos escravos". ${ }^{178}$

Nota-se, portanto, que os negócios mercantis e creditícios envolvendo os escravos como garantia tornaram-se freqüentes no transcurso do Oitocentos, não somente pelo aumento do contingente de escravos e da elevação do preço dos mesmos, mas também pela expansão do quantitativo dos proprietários de escravos nas diversas regiões do Império, sobretudo nas áreas onde se registrou uma maior dinamização das atividades econômicas geradoras de rendas no contexto do país no referido período.

69, Inverno, 2008 - Disponível em www.revistas2.uepg.br/index.php/rhr/article/view/2270/1757 , acesso em 30/07/2011.

177 Ibidem, p. 66.

${ }^{178}$ Cf. LUNA, F. V. \& KLEIN, H. Escravismo no Brasil. São Paulo: Edusp/Imprensa Oficial, 2010, p. 143. 
Nesta perspectiva, constatamos que tais práticas também foram usuais em São Mateus à época, haja vista que no conjunto da documentação cartorária investigada, encontramos um significativo número de escrituras referentes aos negócios dessa natureza (v. Tabela 23) e sobre os quais nos debruçaremos na sequiência deste tópico.

Tabela 23: Documentos avulsos/ negócios com escravos em São Mateus (1863-1887).

\begin{tabular}{lc}
\hline Tipo de documento/escritura & $\mathrm{N}^{\mathbf{o}}$ \\
& incidência \\
\hline Escritura de Dívida e Hipoteca & 30 \\
Permuta de escravos (as) / Troca de escravos & 07 \\
Contrato /Escritura de Contrato / Contrato de Sociedade Agrícola (e/ou de lavoura) & 06 \\
Escritura de doação causa-mortes (ou causa-mortis) & 05 \\
Escritura de penhor / Empréstimo e/ou Dívida sob Penhora. & 13 \\
Escritura de dação in solutum (para pagamento de débito) & 05 \\
Doação & 02 \\
Total de documentos & 68 \\
\hline
\end{tabular}

Fonte: Diversos Livros de Notas do Cartório do $1^{\circ}$ Ofício Arnaldo Bastos - São Mateus, 1863-1887.

Conforme observamos nos tipos e quantidades da documentação acima discriminada, nota-se que num leque de 68 escrituras reunidas na Tabela 23, determinados documentos apresentam maiores incidências, dentre estes: Escritura de dívida e hipoteca (30 documentos); Escritura de penhor / Empréstimo elou Dívida sob Penhora (13 documentos); Permuta elou Troca de escravos (7 documentos); Contratos (6 documentos); Escritura de doação causa-mortis (5 documentos); Escritura de dação insolutum (5 documentos); e Doação (2 documentos). Esse conjunto de escrituras representa cerca de $90 \%$ do total dos 75 documentos referentes aos diversos tipos de negócios mercantis envolvendo escravos em São Mateus. (v. ANEXO 3)

Ressaltamos ainda que um grupo de 7 escrituras não foram incluídas na Tabela 23, já que as mesmas apresentaram apenas uma incidência no conjunto, quais sejam: Distrato (destrato) de compra (de escravo); Recibo; Escritura de transferência de serviços; Escritura de locação de serviços; Escritura de transmissão mútua de bens imóveis e semoventes; Escritura de substituição de doação; e, Aditamento à escritura.

No caso dessas sete fontes 'avulsas', que apresentam apenas uma amostragem cada, faz-se necessário o exame individual das mesmas, com vistas a destacar os principais itens encontrados em seu conteúdo, no sentido de desvendar certas peculiaridades da escravidão em São Mateus, tal como se observa na escritura referente ao Distrato (destrato) de compra da escrava Leocádia ${ }^{179}$, realizado em 1868 , entre o

\footnotetext{
${ }^{179}$ Cf. Registro datado de 18 de janeiro de 1868 - Livro de Notas no 2, fl.100 - Cartório do $1^{\circ}$ Ofício
} Arnaldo Bastos - São Mateus-ES. 
Tenente Constantino Gomes da Cunha e Manoel Ferreira de Almeida, membros de importantes famílias da oligarquia mateense, dando margem a interpretação de que se trata de um "acordo de cavalheiros" ante algum problema ocorrido depois da compra.

Outra situação curiosa se deu em maio de 1882, no Aditamento à Escritura ${ }^{180}$ referente à venda da escrava preta de nome Benvinda (lavrada em 1 de maio de 1882), cujo aditamento foi realizado praticamente no mesmo dia da venda, para a inclusão da escrava de nome Feliciana (filha de Benvinda) na referida escritura. Provavelmente a intenção desse ato foi o de evitar a separação das duas escravas (mãe e filha), já que, através deste Aditamento elas permaneceriam juntas e sob a posse de uma mesma pessoa - no caso, a D. Anna Luisa Gomes Henrique de Paiva que comprou as referidas escravas de Olindo Antonio dos Santos, o Barão de Timbuí, um forte representante da oligarquia regional. Contudo, deve-se notar que nessa atitude não há sentimentalismo, pois, no contexto da última década da escravidão, os escravagistas eram cada vez mais pressionados tanto pelo movimento abolicionista quanto pela legislação decretada, no sentido de evitar-se a separação da família escrava e também das mães e filhos escravos em função de negócios envolvendo a compra e venda de cativos.

Também consideramos atípica nessa documentação 'avulsa' uma Escritura de substituição de doação, registrada em $1881^{181}$, na qual se faz referência à substituição de bens doados anteriormente, dentre estes se incluindo a substituição dos escravos Evencio, Regina, Angélica e Josefina, conforme disposto no texto da escritura, na qual a doadora é D. Rosa Gomes de Araujo e os beneficiados pela doação são seus filhos e netos. Assim, a alteração no documento original de doação pode ter sido motivada pela ampliação dos membros da família, sobretudo após o nascimento dos netos da D. Rosa.

Dentre as escrituras 'avulsas', consideramos que três dessas podem ser aqui agrupadas, por tratarem de questões relativas ao aluguel e contratação dos serviços de escravos na década de 1870, a saber:

1) Um Recibo de aluguel da escrava parda Lucinda, firmado pelo Sr. Manoel Ignácio das Chagas em $1872{ }^{182}$, após receber do Sr. Joaquim Barbosa de Souza a quantia de

\footnotetext{
${ }^{180}$ Cf. Registro de maio/1882 - Livro de Notas nº 12 , fl.71 - Cartório do $1^{\circ}$ Ofício Arnaldo Bastos - São Mateus-ES.

${ }^{181}$ Cf. Registro datado de 18 de abril de 1881 - Livro de Notas $\mathrm{n}^{\circ} 12$, fl.38 - Cartório do $1^{\circ}$ Ofício Arnaldo Bastos - São Mateus-ES.

${ }^{182}$ Cf. Registro datado de 17 de maio de 1872 - Livro de Notas nº 02, fl. 365 - Cartório do $1^{\circ}$ Ofício Arnaldo Bastos - São Mateus-ES.
} 
$10 \$ 000$ réis a título de aluguel da referida escrava - que já era metade forra e estava acumulando pecúlio no trabalho a jornal para obtenção da liberdade completa;

2) Uma Escritura de transferência dos serviços da liberta Genoveva, emitida pelo Sr. Francisco Marques de Abreu (Transmitente) para o Sr. Domingos Rocha da Silva Rios (Adquirente) em $1878{ }^{183}$, cuja menção à Genoveva como uma "liberta" leva-nos a inferir que esta já dispunha de uma carta de alforria, porém condicionada à prestação de serviços por determinado tempo até conquistar o direito à sua plena liberdade;

3) Uma Escritura de débito, obrigação e locação de serviços do escravo Justiniano ${ }^{184}$, pela quantia de 1:000\$000 rs. por três anos e meio, conforme consta no documento de 1879, onde são partes D. Maria Gomes da Conceição e o Major Antonio Rodrigues da Cunha (futuro Barão de Aimorés e principal representante da oligarquia mateense).

Encerrando este leque de documentos 'avulsos', destacamos a Escritura de transmissão mútua de bens imóveis e semoventes, registrada em 1880, onde figuram os escravos Desiderio, preto, no valor de 1:000\$000 rs., e Lucindo, crioulo, no valor de 1:500\$000 rs., assinando como partes na mesma os sócios componentes da extinta firma Fonseca Rios \& Cia ( já referida em tópico anterior sobre compra e venda de escravos).

Constatamos, portanto, que nesta pequena amostragem de escrituras 'avulsas', fica ainda mais evidente que os cativos de São Mateus foram objeto das mais variadas formas de relações mercantis-escravistas mantidas e conduzidas pelos principais representantes da oligarquia regional no decorrer da segunda metade do século XIX.

3.2.1. Hipotecas, penhoras, aluguel, empréstimos, doações e permutas.

Antes de adentrarmos na análise específica do conteúdo das escrituras reunidas na Tabela 23, é oportuno procedermos a uma caracterização dessas fontes, sobretudo aquelas que apresentam as maiores incidências no conjunto, ou seja, as hipotecas e penhoras de escravos. Tal procedimento torna-se necessário, pois, muitas vezes, no senso comum, hipotecas e penhoras são concebidas equivocadamente como similares, sendo que estas contêm diferenças pontuais, conforme se observa em seus significados:

\footnotetext{
${ }^{183}$ Cf. Registro datado de 27 de julho de 1878 - Livro de Notas no 10 , fl. 36 - Cartório do $1^{\text {o }}$ Ofício Arnaldo Bastos - São Mateus-ES.

${ }^{184}$ Cf. Registro datado de 7 de junho de 1879 - Livro de Notas n ${ }^{\circ} 11$, fl. 91 - Cartório do $1^{\circ}$ Ofício Arnaldo Bastos - São Mateus-ES.
} 
Hipoteca (hypotheca) se refere à sujeição de bens imóveis ao pagamento de uma dívida, sem transferência da posse do bem gravado ao credor; dívida que resulta dessa sujeição; direito ou privilégio que certos credores têm de ser pagos pelo valor de certos bens imóveis do devedor, de preferência a outros credores, dadas certas condições; hipotecar significa, portanto, assegurar e/ou garantir (...) Penhor, por sua vez, diz respeito ao direito real que vincula coisa móvel, ou mobilizável, a uma dívida, como garantia de seu pagamento; a coisa móvel ou mobilizável que constitui essa garantia, geralmente entregue ao credor; sendo que a penhora se refere à apreensão judicial de bens, valores, dinheiro, direitos, etc., pertencentes ao devedor executado, quantos sejam suficientes para garantir a execução judicial de determinada quantia; neste sentido, penhorar significa dar garantia ou afiançar. ${ }^{185}$

Sendo assim, nota-se a priori, que há uma nítida distinção entre hipoteca e penhora no que tange ao tipo de bem a ser enquadrado como garantia em cada um desses instrumentos creditícios, ou seja, enquanto a hipoteca comporta bens imóveis como garantia das dívidas, a penhora só comporta bens móveis ou mobilizáveis enquanto tal, cujo aspecto, por si só já lhes confere uma diferença considerável, a qual se reveste de novos atributos ao atentarmos para a sua significação no contexto do século XIX, onde a emissão dessas escrituras foi regida por legislação específica.

Acerca desta legislação específica referente à hipoteca e penhor de escravos no período em foco, constatamos que o Decreto 482, de 1846, já aludia à "hypotheca" dos escravos (art. $2^{\circ}$ ), sendo que posteriormente, na década de 1860, o sistema de registro cartorial acolheu o penhor de escravos e a hipoteca destes como bens acessórios ao bem principal declarado (a propriedade), cujas prerrogativas foram dispostas na Lei 1.237 de 24 de Setembro de 1864, na seguinte forma:

Art. 2. ${ }^{\circ}$ A hypotheca é regulada somente pela Lei civil, ainda que algum ou todos os credores sejam comerciantes. (...) $\S 1$. $^{\circ}$ Só podem ser objeto de hypotheca: Os imóveis. Os acessórios dos imóveis com os mesmos imóveis. Os escravos e animais pertencentes às propriedades agrícolas, que forem especificados no contrato, sendo com as mesmas propriedades. ${ }^{186}$

No texto dessa legislação subentende-se que a hipoteca de escravos somente poderia ocorrer conjuntamente com a propriedade, já que a mesma lei estabelecia que, no caso de escravos, quando considerados destacadamente, haveria a figura do penhor de escravos, conforme consta no art. 6. ${ }^{\circ}, \S 6 .^{\circ}$ da referida lei: “O penhor de escravos

\footnotetext{
${ }^{185}$ Cf. Pequeno Dicionário Brasileiro da Língua Portuguesa, 11 a edição, GAMMA/Editora Civilização Brasileira S.A., Rio de Janeiro, s/d.

${ }^{186}$ Fragmentos da referida lei, disponível em http://cartorios.org/2010/01/11/soriano-neto-machado-ruy-ea-queima-de-arquivos/, acesso em 31/07/2011 - As demais citações desta legislação e que se seguem no texto também foram retiradas desta mesma referência.
} 
pertencentes às propriedades agrícolas, celebrado com a cláusula constituti, também não poderá valer contra os credores hypothecarios, se o título respectivo não for transcrito antes da hypotheca".

O penhor mercantil de escravos era vedado pelo Código Comercial de 1850 (Lei 556, de 25 de junho de 1850, art.273), sendo, porém, previsto indistintamente pelo regulamento hipotecário (Decreto 3453 de 26 de abril de 1865), no qual foi criado a figura do Livro 6, destinado à transcrição do penhor de escravos, a saber: “Art. 30. O livro n. ${ }^{\circ} 6$ - Transcrição do penhor dos escravos -, servirá para a transcrição do penhor de escravos pertencentes às propriedades agrícolas celebradas com a clausula constituti (art. 6. $.^{\circ} \S 6 .^{\circ}$ da lei)".

Este mesmo decreto igualmente considerou os escravos como bens acessórios da propriedade, nos seguintes termos: “Art. 140. Consideram-se acessórios dos imóveis agrícolas e só podem ser hypothecados com estes imóveis: $§ 1 .^{\circ}$ Os instrumentos de lavoura e os utensílios das fabricas respectivas, aderentes ao solo. $§ 2{ }^{\circ}$ Os escravos e animais respectivos, que forem especificados no contrato". Esta situação é apontada por Perdigão Malheiros já em 1866 ao destacar que: “A hypotheca de escravos não pode hoje recair senão sobre os que pertencerem a estabelecimentos agrícolas, com tanto que sejam especificados no contrato, e só conjuntamente com tais imóveis como acessórios destes, do mesmo modo que os animais". ${ }^{187}$

Segundo Marcondes, o crédito assumiu papel fundamental no desenvolvimento da economia cafeeira no vale do Paraíba paulista, já que, a partir do Código Comercial de 1850 e da legislação hipotecária de 1864/65, a possibilidade de financiamento por meio de hipotecas e de instituições bancárias cresceu expressivamente na região, onde anteriormente o crédito concentrava-se nas mãos de "capitalistas e comissários locais dos grandes centros comerciais, especialmente os da praça do Rio de Janeiro". ${ }^{188}$

Chama atenção no caso de São Mateus, a grande incidência de hipotecas envolvendo escravos (30 documentos), cujos dados e as constatações deles emanadas contribuem para corroborar uma das questões centrais que nos preocupou nesta

\footnotetext{
${ }^{187}$ MALHEIROS, Agostinho Marques Perdigão. A escravidão no Brasil. Ensaio histórico-jurídicosocial. Parte $1^{\text {a }}$ - jurídica. Direitos sobre os escravos e libertos. Rio de Janeiro: Typographia Nacional, 1866 , p.70, § 49.

${ }^{188}$ MARCONDES, Renato Leite. O Financiamento Hipotecário da Cafeicultura no Vale do Paraíba Paulista (1865-87). In: Revista Brasileira de Economia, vol.56 n n $^{\circ}$, Rio de Janeiro, Mar. 2002 disponível em http://www.scielo.br/scielo.php?script=sci_arttex\&pid=S0034-71402002000100006, acesso em 31/07/2011.
} 
investigação, qual seja: demonstrar a existência de uma forte oligarquia agráriomercantil e escravista em São Mateus à época, cujo domínio não se restringia apenas à produção agrícola (farinha e café), mas que ampliava o seu raio de ação na rede de relações envolvendo a circulação e comercialização desta produção, além de controlar os negócios relativos ao comércio de escravos no âmbito regional.

Nesta situação, torna-se evidente que o acesso ao crédito e às transações monetárias no interior da sociedade mateense, estiveram condicionados à disponibilidade de capitais desta oligarquia para investimentos nas diversas conjunturas que marcaram os contextos econômicos nacional/regional no período em foco.

Em outras palavras, as negociações muito recorrentes de empréstimo sob penhora e hipoteca de escravos neste leque documental, evidencia, desde já, que uma boa parcela deste referido capital concentrava-se nas mãos de um seleto grupo de indivíduos da sociedade mateense que, em grande parte, eram elementos integrantes das famílias que compunham a referida oligarquia, aparecendo como credores em diversas situações envolvendo escravos como garantia dos empréstimos/ dívidas ou hipotecas.

Portanto, no total dos documentos cartoriais registrados no decorrer da segunda metade do século XIX em São Mateus, referentes às dívidas na forma de hipotecas (30 escrituras) e penhoras (13 escrituras), e nos quais os escravos (dentre outros bens) constam como garantia das quantias negociadas, identificamos um grupo restrito de indivíduos e/ou firmas que compareceram com maiores incidências nas referidas transações, sendo também detentores do maior quantitativo dos capitais investidos.

Assim, ao compararmos os quadros referentes aos 10 maiores vendedores e compradores de escravos em São Mateus, com a classificação que obtivemos acerca dos sete maiores credores/investidores em negócios creditícios envolvendo escravos naquela praça no mesmo período, chegamos às seguintes constatações:

1. A Firma Leonel Joaquim de Almeida Fundão \& Cia, que figura no topo dos maiores credores nos negócios creditícios, contabilizando um investimento de aproximadamente 29:000\$000rs./ 29 mil contos de réis em transações incluindo hipotecas e penhoras (onde constam 29 escravos como parte das garantias dos empréstimos efetuados), encontra-se também relacionado entre os maiores compradores de escravos (onde ocupa a $9^{a}$ posição), mas não é citado dentre os maiores vendedores de escravos; 
Quadro 1: Maiores credores nas negociações de escravos em São Mateus/ES (1863-1887).

\begin{tabular}{|l|l|l|}
\hline $\begin{array}{l}\text { Credores (dos maiores p/ os } \\
\text { menores investidores) }\end{array}$ & $\begin{array}{l}\text { Total } \\
\text { investido }\end{array}$ & $\begin{array}{l}\text { Número de escravos aceitos } \\
\text { como garantia }\end{array}$ \\
\hline $\begin{array}{l}\text { 1. Firma Leonel Joaquim de } \\
\text { Almeida Fundão \& Cia }\end{array}$ & $29: 043 \$ 185$ & 22 escravos \\
\hline 2. Domingos Rocha da Silva Rios & $24: 962 \$ 898$ & 63 escravos \\
\hline $\begin{array}{l}\text { 3. Major Antonio Rodrigues da } \\
\text { Cunha }\end{array}$ & $23: 047 \$ 000$ & 18 escravos \\
\hline 4. José Alves da Fonseca & $18: 000 \$ 000$ & 13 escravos \\
\hline 5. Tenente José dos Santos Neves & $16: 387 \$ 910$ & 28 escravos + 5 ingênuos \\
\hline 6. Francisco José de Faria & $15: 000 \$ 000$ & 6 escravos \\
\hline $\begin{array}{l}\text { 7. Jerônimo Francisco Afonso } \\
\text { Durães }\end{array}$ & $14: 000 \$ 000$ & 9 escravos \\
\hline TOTAL & $\mathbf{1 4 0 : 4 4 0 \$ 9 9 3}$ & $\mathbf{1 5 9}$ escravos \\
\hline
\end{tabular}

Fonte: Cartório de 1ㅇ Ofício de São Mateus.

2. Domingos Rocha da Silva Rios, por sua vez, além de figurar como o segundo maior credor nas transações creditícias (realizando empréstimos em torno de 25:000\$000 rs./25 mil contos de réis e aceitando 63 escravos como parte da garantia destes investimentos), ocupa também a segunda posição entre os maiores compradores e o $5^{\circ}$ lugar dentre os maiores vendedores de escravos em São Mateus, cujos dados apontam para uma atuação mais ou menos proporcional deste nos três principais ramos de negócios que envolviam o mercado de escravos na região;

3. O Major Antonio Rodrigues da Cunha também se destaca neste sentido, considerando que o mesmo se encontra em $3^{\circ}$ lugar dentre os maiores credores nas hipotecas e penhoras (onde investiu cerca de 23:000\$000 rs./ 23 mil contos de réis e aceitou 18 escravos como parte das garantias dos empréstimos), sobressaindo-se como o maior comprador de escravos em São Mateus, além de ocupar a $10^{a}$ posição entre os maiores vendedores de escravos no âmbito regional;

4. Acerca dos demais indivíduos que comparecem entre os maiores credores nos negócios creditícios em São Mateus - quais sejam: José Alves da Fonseca (em $4^{\circ}$ lugar, com 18:000\$000 rs./18 mil contos de réis - investidos e 13 escravos aceitos como parte das garantias); o Tenente José dos Santos Neves (em 5 lugar, com 16:000\$000 rs./ 16 mil contos de réis investidos e 28 escravos aceitos como parte das garantias); Francisco José de Faria (em 6 ${ }^{\circ}$ lugar, com 15:000\$000 rs./15 mil contos de réis investidos e 6 escravos aceitos como parte das garantias); e Jerônimo Francisco Afonso Durães (em $7^{\circ}$ lugar, com 14:000\$000 rs./14 mil contos de réis investidos e 9 escravos aceitos como parte das garantias) -, constatamos que seus nomes não se encontram entre os 10 maiores compradores e nem entre os 10 maiores vendedores de escravos na cidade, 
indicando que suas atuações estavam mais concentradas nas transações creditícias operadas naquela praça. 
CAPÍTULO 4

PADRÕES DAS ALFORRIAS EM SÃO MATEUS 
$\mathrm{Na}$ segunda metade do Oitocentos as lavouras de café expandiram-se pelo extremo norte capixaba, tornando-a mais uma região produtora da rubiácea na Província do Espírito Santo. Numa escala de produção mais modesta que a obtida na região sul, e complementando a produção da farinha de mandioca, a implantação da lavoura cafeeira na região gerou novas fontes de renda baseada em uma mão-de-obra quase toda produzida pelo braço escravo. A riqueza gerada pela exportação do café produzido pelo trabalho escravo, demandou muitas movimentações econômicas - incluindo aí as que utilizavam-se do escravo não só como produtor agrícola, mas efetivamente deste enquanto capital mercantil, enquanto objeto mercadológico - refletindo também um aumento na demanda das alforrias. Assim, o estudo das alforrias em São Mateus corresponde a de um município em relativa expansão econômica, visto que se trata de uma região que se manteve arraigada ao escravismo até os momentos finais da escravatura, podendo ser definida como um espaço moldado em relações sociais de produção escravista.

Neste contexto, este capítulo propõe-se a estudar os padrões das alforrias em São Mateus a partir do exame das variáveis contidas nas cartas de liberdade, tais como preços, sexo, idade entre outros, visando delinear alguns aspectos de sua demografia escrava.

As cartas de alforria, também denominadas de cartas de liberdade, registradas no Livro do Notariado (ou Livro de Notas) do Cartório de $1^{\circ}$. Ofício de São Mateus constitui a documentação básica, através da qual buscaremos analisar, tanto quantitativa, como qualitativamente, o processo de alforrias em São Mateus na segunda metade do Oitocentos.

No exame desse conjunto documental, procuramos extrair o maior número de dados contidos nos 172 documentos registrados entre os anos de 1863 e 1888, utilizando-se e amparando-se numa metodologia quantitativa, tentaremos estabelecer os ritmos das manumissões na região de São Mateus no último quartel da escravatura, tendo como referência, sempre que possível, as variações determinadas pelas mudanças conjunturais verificadas a partir de 1850, marco de abolição do tráfico externo de africanos para o Brasil.

Em relação à adoção desta metodologia, devemos ressaltar que, não só a história econômica, mas também a história social, absorveu muitos dos avanços experimentados pelas pesquisas seriais a partir da década de 1960. Embora essa quantificação para a 
história social tenha apresentado alguns limites - os quais só foram avaliados na década de 1980, quando então já se esboçara uma 'história social de base quantitativa' ${ }^{189}$ - nas duas últimas décadas do século $\mathrm{XX}$ os trabalhos de história social com séries e metodologias quantitativas se desenvolveram e se multiplicaram, formando linhas de pesquisas consolidadas.

Neste contexto, foi se constituindo uma história social da escravidão, a partir de uma proposta que implicava em uma renovação temática e metodológica, a qual resgatou questões antes minimizadas pela historiografia, referentes à história da sociedade escravista brasileira, que, por sua vez, refletiu-se na história da sociedade brasileira como um todo. Verificou-se um impulso nos trabalhos quantitativos, em sua maioria voltados para o estudo da demografia escrava, principalmente no que se refere à recomposição da população cativa. O estudo das alforrias se insere nessas novas perspectivas, sobretudo pela metodologia adotada, que, a partir de então, torna-se mais rigorosa em relação à pesquisa documental.

O conjunto documental referente à escravidão em São Mateus, registrado no Livro de Notas, fornece um aporte de dados estatísticos muito útil para o tratamento de alguns aspectos da sociedade escravista regional na segunda metade do século XIX. No caso específico que interessa ao presente capítulo em questão - os padrões ou a tipologia das alforrias -, não obstante a inexistência de informações mais seguras ${ }^{190}$ sobre o tamanho da população escrava, liberta e mesmo livre da região estudada, os documentos do Notariado nos permitem reter informações mais precisas acerca de determinadas variáveis, tais como origem, profissão, idade, gênero, valorização do escravo etc, fundamentais ao entendimento da prática de manumissões.

Estas informações, por sua vez, auxiliam na observação da composição da população escrava, sua distribuição pelo território, seus padrões de ocupação, as formas de distribuição da propriedade escrava, entre outros aspectos. Frente a tais informações, objetivamos neste capítulo verificar e analisar também, embora não seja objetivo central, a contribuição das alforrias para o entendimento da chamada 'resistência escrava'.

\footnotetext{
${ }^{189}$ CASTRO, Hebe Matos de. História Social. In: CARDOSO, Ciro F. S. e VAINFAS, R (orgs). Domínios da História: ensaios de teoria e metodologia. Rio de Janeiro: Campus, 1997, p. 49.

${ }^{190}$ Conforme constatamos na literatura sobre o tema, e também em certos relatórios presidenciais na Província do Espírito Santo (a exemplo do de Costa Pereira), a maioria dos levantamentos/censos demográficos realizados no decorrer da segunda metade do século XIX não são confiáveis e apresentam diversas lacunas. Contudo, são esses dados estatísticos que apóiam a maior parte das pesquisas e estudos realizados até então, a exemplo dos trabalhos de Vilma Almada e Nara Saletto.
} 
Para tanto, utilizaremos em linhas gerais as referências bibliográficas e estudos de caso produzidos por alguns pesquisadores no tocante às cartas de alforrias do século XIX, numa tentativa de melhor apreender o conceito de 'visão da liberdade' fornecida através das mesmas.

Para o pesquisador João José Reis o 'resistir escravo' não tinha de ser necessariamente manifesto em atos violentos, "em geral atitudes extremas como fugas, crimes e suicídios só entravam em cena quando a negociação falhava ou não acontecia por intransigência senhorial ou impaciência escrava", e embora muitos atos escravos pressupunham resistência ao sistema escravista, "as cartas de alforria, juntamente com a fuga, eram as formas mais comuns de resistência à escravidão". ${ }^{191}$

Com referência em Eisenberg, partimos da hipótese de que muitas características do alforriado-padrão variavam conforme as determinações específicas no tempo e espaço. Nesta perspectiva, torna-se mais relevante

discutir estas transformações históricas na alforria do que insistir num
padrão único para todo o Brasil em quatro séculos de história. A força das
conclusões dependerá, necessariamente, da representatividade dos dados:
algumas características ou variáveis constaram em todas as cartas, outras
apareceram menos ou em quase nenhuma. ${ }^{192}$

A partir de Eisenberg e de outros pesquisadores que adentraram no tema das manumissões no Brasil, devemos salientar que o fator econômico nem sempre é o único citado para explicar as alterações na frequiência de alforrias, sendo que outros fatores também podem ser apontados, tais como o demográfico e o político, entre este, as campanhas abolicionistas, para o caso das duas últimas décadas da escravidão. Neste sentido, o fenômeno da manumissão, como qualquer outro aspecto do regime escravocrata, deve ser analisado com relação à situação sócio-política e econômica predominante.

Em se tratando de uma região como a de São Mateus, a qual deve ser considerada sem vínculos diretos com a economia de exportação - como o modelo tradicional da plantation - a exemplo do sul da província (a região de Itapemirim) totalmente voltada para a realidade econômica do Vale do Paraíba, pode-se afirmar com

\footnotetext{
${ }^{191}$ REIS, João J. e SILVA, Eduardo. Negociação e conflito: a resistência negra no Brasil escravista. São Paulo: Companhia das Letras, 1989, p.19.

${ }^{192}$ EISENBERG, Peter. L. A Carta de alforria e outras fontes para estudar a alforria no século XIX. In: Homens esquecidos: escravos e trabalhadores livres no Brasil - séc. XVIII e XIX. Campinas: Ed. da UNICAMP, 1989, p. 257.
} 
base na observação de pesquisas de regiões que se enquadram no modelo citado, que a maior parte de sua escravaria, pelo menos a partir do início do século XIX, se reproduziam internamente. Em toda a sua trajetória, a região enfocada manteve-se direcionada para o abastecimento do mercado interno, seja ele regional, provincial ou interprovincial. ${ }^{193}$ Este fato possibilitou a constituição de famílias escravas, assim como ocorreu em outras partes da província, ${ }^{194}$ o que refletiu, certamente, na questão da obtenção de alforrias. ${ }^{195}$ Devido à falta de pesquisas quantitativas acerca da reprodução endógena da escravaria mateense, tanto da escrava propriamente dita, quanto da 'libertanda', ou mesmo da população forra, torna-se impreciso apresentar afirmativas mais exatas acerca de certas tendências que marcaram a variação demográfica desses contingentes.

Segundo a historiografia brasileira mais recente dedicada aos estudos das manumissões, do cotidiano escravo e das formas de resistência escrava, a partir de 1850 o número absoluto dos libertos começou a aumentar, não só por causa da intervenção do governo imperial na abolição do tráfico e na promulgação de leis emancipacionistas, mas também por conta da ação dos próprios escravos, que começam a dar sinais maiores de contestação a sua condição cativa e a questionar a legitimidade do poder senhorial. Nesse sentido, os estudos se debruçaram sobre as estratégias dos cativos para alcançar a liberdade.

Dessa forma, uma das primeiras indagações que nos vem à tona, diz respeito aos fatores que influíram na determinação da ocorrência de alforrias em determinados períodos de tempo na região de São Mateus.

Alguns autores apontaram a depressão ou decadência econômica como o fator mais importante para o aumento das alforrias, a exemplo de Schwartz sobre a Bahia de

\footnotetext{
${ }^{193}$ Um caso parecido foi o do Paraná. v. GUTIÉRREZ, Horacio. Demografia Escrava numa Economia Não-Exportadora: Paraná, 1800-1830. Estudos Econômicos, São Paulo, 17 (2): 297-314, maio/ago,1987. Conforme Gutiérrez, "constata-se entre os escravos do Paraná um significativo equilíbrio entre os sexos, baixa idade mediana da população, elevada magnitude de crianças escravas, de sorte que sua feição demográfica revela-se similar àquela encontrada na população livre. Tudo indica que a reprodução natural teve peso decisivo na conformação dessa estrutura, e surpreendentemente num período no qual o tráfico de africanos para o Brasil alcançava proporções inéditas".

${ }^{194}$ Ver CAMPOS, Adriana Pereira. Escravidão e creolização: a Capitania do Espírito Santo, 1790-1815. In: FRAGOSO, FLORENTINO, JUCÁ e CAMPOS (orgs.) Nas Rotas do Império. Vitória: EDUFES, 2006, p. 587.

${ }^{195}$ Tudo indica que a reprodução da escravaria mateense foi endógena, embora a região possuísse porto marítimo e contatos, ora freqüentes, com embarcações estrangeiras, registrando-se a entrada de escravos de diversas nacionalidade africanas. Há hipóteses (vagas e baseadas em relatos da história oral) da existência de contrabando de escravos chegados diretamente da África na região, destacando-se inclusive o fato de uma das últimas apreensões de navios negreiros na costa brasileira ter ocorrido na região de São Mateus (1856).
} 
fins do século XVII e primeira metade do XVIII, ao sugerir que "o aumento das alforrias pagas pode refletir um esforço dos senhores de escravos, no sentido de estimular a produtividade em momentos recessivos, através do aumento da oferta de oportunidades para a alforria". ${ }^{196}$ Para o século XIX, Kátia Mattoso reafirma as idéias de Schwartz acerca da incidência de alforrias na Bahia, em situações de conjuntura desfavorável, "onde os proprietários, carentes de dinheiro, realizavam o capital investido no escravo". ${ }^{197}$ (grifo nosso)

Já para as Minas Gerais, Francisco Vidal Luna e Iraci del Nero da Costa pesquisaram, a partir de Listas Nominativas de habitantes, libertos que se tornaram proprietários de escravos, no auge da mineração do ouro a partir do segundo quartel do século XVIII, e concluíram que a natureza do processo de trabalho associado à conjuntura favorável do momento, facilitavam a obtenção de alforrias. ${ }^{198} \mathrm{Na}$ estrutura de posse analisada por Costa \& Luna, um quinto dos forros eram proprietários de escravos no distrito diamantífero de Serro Frio: os forros representavam a expressiva parcela de $22,5 \%$ dos senhores.

Complementando, o trabalho de Andréia Lisly Gonçalves acrescenta que, nas Minas Gerais do século XIX, embora houvesse correspondência direta entre alforria e conjuntura econômica, (como no século XVIII), sempre em situação de crise ou não, a alforria era parte do domínio senhorial e não do escravo. ${ }^{199}$

A questão do domínio e do controle senhorial sobre os escravos, sempre constituiu ponto importante das discussões das relações escravistas no Brasil. Sendo concedidas, em sua maioria, mais para mulheres e crianças do que para homens, a carta de alforria impunha-se também como instrumento de manutenção da escravidão, visto que muitas vezes a liberdade do escravo vinha acompanhada de uma série de condições, reafirmando assim a dependência do libertando com relação a seu proprietário.

Em contraposição à situação das alforrias mineiras do século XIX colocadas por Lisly, a situação das alforrias analisadas por Schwartz na Bahia o levaram a afirmar que,

\footnotetext{
${ }^{196}$ SCHWARTZ, Stuart. Segredos internos: engenhos e escravos na sociedade colonial: 1550-1835. São Paulo: Companhia das Letras, 1988, p. 331.

${ }^{197}$ MATTOSO, 1976, p. 156.

${ }^{198}$ LUNA, Francisco Vidal e COSTA, Iraci del Nero da. A presença do elemento forro no conjunto de proprietários de escravos. Ciência e Cultura. 32(7), julho de 1980.

${ }^{199}$ GONÇALVES, Andréia L. As margens da liberdade: alforrias na comarca de Ouro Preto (1808/1870). São Paulo: USP, 2000 (Tese de doutorado).
} 
As limitações do escravismo eram reais e freqüentemente também destrutivas, mas daí crer (...) que a força inerente ao poder dos senhores e o funcionamento da instituição da escravidão determinaram, sozinhos, os parâmetros da vida escrava, é deixar de lado o papel essencial dos cativos na criação de sua própria cultura. ${ }^{200}$

Acerca desse tema, a pesquisa de Enidelce Bertin, sobre as alforrias em São Paulo no século XIX, esclarece "que os documentos de alforrias, muitas vezes apontaram para formas refinadas de domínio, entre elas o paternalismo, da qual faziam parte a mobilidade e a autonomia dos escravos". ${ }^{201}$ Bertin identifica a cidade de São Paulo como centro de convergência de escravos das fazendas do interior, seja libertos, libertandos ou mesmo escravos fugidos, que para lá afluíam com a intenção de obter pequenos ganhos com o lucro do comércio, podendo também desfrutar de maiores mobilidades físicas. Esta situação acabou gerando uma 'autonomia' escrava que na realidade era uma forma refinada de paternalismo. Sobre as alforrias, a autora esclarece que, apesar dos textos das cartas que procuram enaltecer a amizade e o amor que os proprietários possuíam com seus escravos, estas não eram via de regra, um ato fraterno. Na realidade, "as cartas eram utilizadas como um instrumento de controle pelos senhores de possíveis rebeliões escravas". ${ }^{202}$ A autora chama a atenção para o fato de que as alforrias não eram, na maioria das vezes um ato fraternal mas sim um instrumento de controle pelos senhores de rebeliões escravas.

Outros temas relacionados ao domínio e ao controle senhorial no Brasil também merecem destaque, tais como o das relações entre compadrio e alforria, visto que estas relações poderiam dar margem às estratégias de busca permanente pela liberdade. ${ }^{203}$

Alguns autores, a exemplo de Robert Slenes, perceberam a elaboração das relações de compadrio católico (no momento do batismo ou do casamento) como um

\footnotetext{
${ }^{200}$ SCHWARTZ, Stuart B. Segredos Internos: Engenhos e escravos na sociedade colonial. São Paulo: Companhia das Letras, 2005, p. 311-312.

201 BERTIN, Enidelce. Alforrias na São Paulo do século XIX: liberdade e dominação. São Paulo: Humanitas/USP/FFLCH, 2004, p. 36.

${ }^{202}$ Ibidem, p. 67.

${ }^{203}$ Tanto a alforria quanto as relações de compadrio eram para os cativos, alternativas constantes para fugir do cativeiro, uma possibilidade de esperança para eles, na tentativa de encontrar melhores condições de vida no universo escravista do Brasil. Assim como as alforrias, o compadrio se constituía em um estratégico elemento de consolidação de laços de sociabilidade naquela sociedade, formando laços afetivos entre a população escrava, livre e liberta. De fato, as relações de compadrio eram profundamente reguladas por solidariedades, parentescos, afinidades, e por vezes marcadas por vínculos de paternidade declarada entre padrinhos e afilhados. O compadrio tinha também funções políticas, pois em lugares que existia grandes plantéis de escravos os níveis de apadrinhamento de cativos geralmente eram mais consistentes. BERTIN, Enidelce. Alforrias na São Paulo do século XIX: liberdade e dominação. São Paulo: Humanitas/USP/FFLCH, 2004.
} 
instrumento que permeava o sistema escravista, articulando-se através de laços morais com indivíduos de maior influência para proteger a si e a sua prole, e eventualmente para ajudar posteriormente na compra da alforria. ${ }^{204} \mathrm{O}$ compadrio era uma aliança utilizada de diversas maneiras por escravos e libertos, sendo um recurso presente na construção de uma comunidade de cativos e livres de cor. Muito mais que o casamento, o compadrio católico favorecia as relações entre escravos e proprietários, entre livres e cativos, entre pardos e brancos de maneira geral.

Estes estudos situam o escravo enquanto agente social e a alforria, neste contexto, passa a ser uma conquista dos escravos. Assim, a participação dos cativos no processo de alforria passou a simbolizar uma ação de resistência à escravidão, expressando o consenso dos escravos na busca de liberdade.

A vontade dos senhores em conceder a liberdade a seus escravos, seja ela gratuita, paga ou condicional durante muito tempo foi a principal perspectiva abordada nos estudos relativos às alforrias, pois estes foram realizados não pela perspectiva dos cativos e da sua luta para alcançar a condição de forros.

Antes de adentrarmos no tema específico do capítulo, faremos alguns esclarecimentos acerca do registro, do conteúdo e do processo de elaboração das cartas, e a seguir analisaremos os padrões das mesmas.

\subsection{Conteúdo, processo de elaboração e registro das cartas de alforrias.}

No Brasil, durante todo o período escravista, a alforria foi um instrumento básico que transmitia a liberdade ao escravo, embora somente em 1824 tenha sido estipulada, pela primeira vez, a situação jurídica do alforriado, quando foi outorgada a primeira Constituição Brasileira. Neste contexto, a alforria se torna um instrumento legal, através do qual se documentava a passagem de um indivíduo de uma condição legal de escravo para uma condição legal de livre ${ }^{205}$. Na realidade o autor nesta passagem tem a pretensão de se referir à condição legal de liberto - há um erro conceitual neste caso.

\footnotetext{
${ }^{196}$ SLENES, Robert. Na senzala uma flor: esperanças e recordações na formação da família escrava. Brasil sudeste, século XIX. Rio de Janeiro: Nova Fronteira (Coleção História do Brasil), 1999.

${ }^{205}$ EISENBERG, Peter. L. A Carta de alforria e outras fontes para estudar a alforria no século XIX. In: Homens esquecidos: escravos e trabalhadores livres no Brasil - séc. XVIII e XIX. Campinas: Ed. da UNICAMP, 1989, p. 245.
} 
Porém só em 1871, com a Lei do Ventre Livre, é que tornava-se legal o direito do escravo de lutar pela sua alforria. ${ }^{206}$

Em muitas situações o documento da alforria era feito diretamente no cartório, em outras não, neste caso, era, pois, preciso lançar posteriormente o documento em cartório. Sendo assim, as cartas podiam ser apresentadas para registro em cartório pelo senhor ou pelo próprio alforriado (ou por um representante de uma das partes) sendo que a data do registro, às vezes, não coincide com a data da redação do documento, possuindo enormes intervalos de tempo, conforme podemos verificar nas cartas de São Mateus.

Neste sentido somos induzidos a pensar na probabilidade de ter havido um número bem maior de alforrias, cartas estas que foram concedidas e que não foram registradas.

Havia duas formas de registro: o de traslado e o de lançamento de carta de liberdade. A primeira forma era para os casos em que o escravo já havia recebido a liberdade e somente agora estava registrando-a em cartório. O notário copiava a carta no livro de registro e entregava uma cópia ao escravo, registrando-a, sendo anotadas duas datas no documento, a de concessão (ou declaração) e a do registro. O lançamento, por sua vez, era para os casos de liberdade concedida concomitantemente ao registro, constando duas datas iguais no documento, a da concessão (ou declaração) e a do registro.

Segundo Eisenberg, para registrar uma carta de alforria, o senhor ou seu procurador, chamava o tabelião para sua residência ou ia ao cartório e ditava os termos da carta para um escrivão. Se a carta já existisse, como no caso dos alforriados vindos de outros municípios e querendo documentar sua condição na nova residência, era só copiá-la. O cartório entregava a original para o senhor ou para o ex-escravo e transcrevia uma cópia para o livro de notas. Essa carta era datada, assinada, e atestada

\footnotetext{
206 Acerca da iniciativa de cativos, Maria Beatriz Nizza da Silva nos esclarece que, "na segunda metade do século XVIII e início do XIX, todo o processo pelo qual o escravo lutava pela sua alforria contra a vontade do senhor, recorrendo à autoridade mais próxima do governador ou ao soberano de Lisboa, estava já permeado, entre os letrados que dele participavam, de conceitos próprios das Luzes e certamente recebia a influência da escravidão em Portugal". Cf. SILVA, Maria Beatriz Nizza da (org.). A luta pela alforria. Brasil - Colonização e escravidão. R.J.: Nova Fronteira, 2000, p. 306.
} 
por duas testemunhas e pelo próprio tabelião, e pagava-se uma pequena importância em selos, para oficializar o ato. ${ }^{207}$

O registro oficializava a liberdade, sendo importante não só para o escravo, mas também para os proprietários que intencionavam garantir os termos acertados no contrato. Nos casos das alforrias condicionais, em que a liberdade exigia prazo para ser alcançada, o ato de inscrever a carta de manumissão no Livro do Notariado dava segurança ao escravo, mas atendia primordialmente ao interesse do senhor, principalmente nas situações de cartas compradas a longo prazo, com datas estabelecidas para pagamento. Já as cartas de liberdade incondicionais, ou gratuitas, atendiam diretamente ao interesse do escravo, visto que não havia exigências préestabelecidas pelo proprietário e a liberdade era alcançada de imediato - neste caso, deveria ser o escravo o maior interessado em registrá-la. Nestes registros, era comum os proprietários demonstrarem preocupação em garantir a alforria, declarada segundo sua 'espontânea vontade' ou até mesmo 'graciosidade', o que reforça o caráter de benemerecência que envolvia a alforria.

Em se tratando de formalidade,

registrar a carta de alforria em cartório poderia representar algo além do que dar garantias jurídicas a um documento expedido em âmbito particular (...). O registro civil poderia apresentar uma dimensão simbólica cujo alcance talvez ajude a esclarecer o significado da condição de liberto em relação a de escravo, mesmo que tal não se desdobrasse em qualquer modificação significativa das condições vividas sob o cativeiro'. ${ }^{208}$

Neste sentido, a leitura de cartas de alforrias inscritas em Livros de Notas de tabelionatos não é um procedimento linear, e não existe um padrão único para os termos que aparecem nestes documentos, visto que há uma variedade enorme das informações contidas nestas. Uma outra questão observada é a forma de redigir dos tabeliães, que muitas vezes simplesmente copiavam a fala de uma das partes envolvidas, fala esta às vezes confusa para explicar o intento, ou recopiava o texto já inscrito em outros documentos cartoriais, tais como testamentos, inventários post-mortem e outros. Percebe-se nitidamente que não há uniformidade na compreensão que os notários

${ }^{207}$ EISENBERG, Peter. L. A Carta de alforria e outras fontes para estudar a alforria no século XIX. In: Homens esquecidos: escravos e trabalhadores livres no Brasil - séc. XVIII e XIX. Campinas: Ed. da UNICAMP, 1989, p. 246-247.

208 GONÇALVES, Andréia L. As margens da liberdade: alforrias na comarca de Ouro Preto (1808/1870). São Paulo: USP/FFLCH, 2000 (Tese de doutorado), p. 224. 
possuíam ao elaborarem a documentação sobre as diferentes condições a que estivera submetida a maioria dos libertandos. Dependendo da redação podia ficar uma 'brecha' para uma possível reescravização do liberto, pois até 1871, havia a possibilidade de revogação das alforrias sob a alegação de ingratidão por parte do escravo. ${ }^{209}$ Schwartz nos informa que, devido a essa possibilidade de reescravização, os libertos normalmente guardavam em seu poder a carta original, visto que a escravidão ilegal de pessoas de cor era sempre um risco, mas para se protegerem e legalizarem plenamente a mudança de status, o documento era levado ao cartório mais próximo e registrado em livro. ${ }^{210}$

\subsection{As diversas modalidades das alforrias.}

Tendo em vista os diversos arranjos que podiam ser feitos em torno do processo da alforria, a observação dos estudos que abordam a questão das manumissões no Brasil, mesmo com muitas variações, classificam as diferentes categorias de manumissões em dois tipos básicos, a saber:

- as alforrias pagas ou compradas pelos escravos ou terceiros (vendidas pelos proprietários), também chamadas de alforrias onerosas ou condicionais, e cujo pagamento podia ser feito em dinheiro, mercadoria ou prestação de serviços, ou de uma combinação de prestação de serviços e pagamento, podendo ser incluído também nesse conjunto, as coartações (cuja característica principal é a compra da alforria em parcelas, que são pagas através de serviços por tempo determinado, principalmente a terceiros);

- as alforrias gratuitas ou 'espontâneas', 'doadas' ou 'concedidas' pelo senhor sem ônus, incluindo nesse grupo as chamadas alforrias incondicionais $;{ }^{211} \mathrm{e}$,

- as alforrias conquistadas por via judicial, em que o juiz estipula a sentença, a qual pode resultar a favor do escravo ou não (neste caso o juiz estipula um valor a ser pago por este), encontradas nos registros cartoriais de São Mateus, constituindo-se numa

\footnotetext{
${ }^{209}$ A Lei de 1871, ou Lei do Ventre Livre, influenciou a prática das alforrias, visto que a partir de então tornava-se legal o direito do escravo de lutar pela sua alforria.

${ }_{210}$ SCHWARTZ, Stuart B. Escravos, roceiros e rebeldes. Bauru: EDUSC, 2001, p. 174.

${ }^{211}$ Várias são as designações para esses conjuntos de alforrias, como por exemplo, a de Antonio Henrique Duarte Lacerda, que classifica as alforrias de Juiz de Fora no século XIX em: alforrias onerosas ou gratuitas condicionais, alforrias incondicionais, alforrias parciais, alforrias de verba testamentária; e a de Alessandra Gomes Caetano que a classifica as de Uberaba e Franca em duas categorias: onerosas e gratuitas. As onerosas se tipificam em condicionais pagas, condicionais não-pagas, e incondicionais pagas. Ver, respectivamente, LACERDA, Antonio H. D. Os padrões das alforrias em um município cafeeiro em Expansão (Juiz de Fora, Zona da Mata de Minas Gerais, 1844-88). São Paulo: FAPEB/Annablume, 2006 e GOMES, Alessandra Caetano. Em busca da liberdade: as alforrias em duas regiões do sudeste escravista, 1825-1888. Dissertação de Mestrado. São Paulo:USP/FFLCH, 2008.
} 
classificação à parte, por serem menos numerosas, embora freqüentemente encontrada na literatura das manumissões no Brasil.

Esta classificação pode servir de referencial para possíveis comparações entre os padrões de alforria em diferentes regiões do país e aqueles registrados na Província do Espírito Santo e na região de São Mateus. No entanto, não podemos perder de vista que há diversos outros tipos de alforrias que não se encaixariam com desenvoltura nessa classificação.

Assim, antes de adentrarmos na análise dos padrões das alforrias é necessário fazer algumas considerações acerca de sua tipologia para esclarecer alguns de seus significados.

Seguindo as análises de Alessandra Caetano Gomes ${ }^{212}$, existem dois grandes grupos de alforrias na literatura das manumissões: as onerosas e as gratuitas. As alforrias gratuitas seriam as doadas ou concedidas pelo proprietário a título gratuito, ou seja, não há ônus monetário ou condição para o escravo cumprir. Na documentação de São Mateus encontramos várias cartas dessa categoria, a exemplo das que se seguem:

Registro de Carta de Liberdade de Dorothéa, conferida por seu senhor o alferes Andrelino Leite de Barcelos na forma abaixo. [Carta de Liberdade conferida a favor da escrava Dorothéa]. Eu, abaixo assinado, Andrelino Leite de Barcelos, declaro que dentre os bens que possuo, tenho livre de embargos de todo e qualquer ônus a escrava de nome Dorothéa, que pelos bons serviços que me tem prestado e concedo sua liberdade por minha livre e espontânea vontade, ficando como: fica livre de hoje para sempre como se assim nascesse. E para clareza mandei passar a presente Carta a qual assino. São Matheus, onze de agosto de mil oitocentos e setenta e nove. Andrelino Leite de Barcelos. Reconheço ser verdadeira a presente. São Matheus doze de agosto de mil oitocentos e setenta e nove. Sebastião de Oliveira. Tabelião o nome assino em público Sabino José de Oliveira. São Matheus, doze de agosto de mil oitocentos e setenta e nove. Tabelião Sabino José de Oliveira. ${ }^{213}$

Registro de Carta de Liberdade de Ricardo. Pela presente, na qualidade e procurador bastante do meu cunhado, José Antônio de Oliveira Júnior, conforme a procuração datada de maio nas notas do tabelião Couto Grito, livro 52 folha 196v na Corte passada Rosário número 96, concede plena e inteira liberdade gratuita ao escravo de nome (rasurado), digo de nome Ricardo, crioulo, filho de Lourenço, matriculado na Colletoria Geral desta cidade com o número 1462 da matricula geral em vinte e seis de agosto de mil oitocentos e setenta e dois e para constar, faço e assino a presente. São Matheus, quatorze de maio de mil oitocentos e oitenta e quatro. Joaquim

\footnotetext{
${ }^{212}$ GOMES, Alessandra Caetano. Em busca da liberdade: as alforrias em duas regiões do sudeste escravista, 1825-1888. Dissertação de Mestrado. São Paulo: USP/FFLCH, 2008.

${ }^{213}$ Cartório de $1^{\circ}$ Ofício de São Mateus - Espírito Santo, Livro 11 - Folha 109 v.
} 
Monteiro de Morais. Reconheço verdadeira a firma supra. São Matheus, quatorze de maio de miloitocentos e oitenta e quatro. Eu, Sabino José de Oliveira, tabelião, a escrevi em publico e rogo com testemunho e sinal publico. Sabino José de Oliveira. D. Gr. Que nada mais tinha na dita carta que fielmente aqui registrei e a mesma reporto em poder do apresentante. São Matheus, quatorze de maio de mil oitocentos e oitenta e quatro. Tabelião Sabino José de Oliveira. ${ }^{214}$

O primeiro caso trata-se de um lançamento de carta de liberdade, pois a concessão e o registro foram feitos com a diferença de um dia apenas (onze e doze de agosto de 1879) e no segundo caso, do registro de um traslado, cuja cópia original foi feita no Rio de Janeiro (Corte), mas que só agora (14 de maio de 1884) estava sendo registrada em cartório, neste caso no Cartório de São Mateus. Ambas as cartas colocamse na categoria de gratuitas. Na literatura das manumissões estas cartas gratuitas são chamadas também de incondicionais, por grande parte dos pesquisadores.

Quanto à categoria onerosa, também chamadas por grande parte dos pesquisadores de alforrias condicionais, em que o escravo tem que cumprir uma condição ou pagar uma quantia, as tipificações aumentam. Nesse conjunto, Gomes diferencia as alforrias condicionais pagas, condicionais não-pagas e as incondicionais pagas. As alforrias condicionais pagas seriam aquelas nas quais o escravo teve que cumprir uma obrigação, ou condição e no mesmo documento se viu obrigado a realizar um pagamento que podia ser feito em dinheiro ou em mercadorias; as condicionais nãopagas são aquelas em que o escravo apenas teve que cumprir uma condição geralmente relacionada ao cumprimento de uma obrigação para com o proprietário ou terceiros, a quem este indicasse; nas incondicionais pagas, o escravo ou um terceiro teve que pagar por sua liberdade, mas não foi necessário cumprir obrigação ou condição para se tornar liberto, geralmente após o pagamento o escravo se tornava forro. ${ }^{215}$

Na documentação de São Mateus, temos alguns casos de alforrias incondicionais pagas, (as quais estão incluídas no conjunto das onerosas/ pagas), a exemplo dos seguintes registros:

Registro de Carta de Liberdade da escrava Laura. Pela presente dou esta carta de liberdade a minha escrava Laura, matriculada neste município, com a matricula 1446 da Matricula Geral da Relação pela quantia de seiscentos mil réis que recebi de seu benfeitor José Joaquim de Souza Graça a passo desta podemos desde já entrar na posse de sua liberdade como se de

\footnotetext{
${ }^{214}$ Cartório de $1^{\circ}$ Ofício de São Mateus - Espírito Santo, Livro 19 - Folha 10v e 11.

215 GOMES, Alessandra Caetano. Em busca da liberdade: as alforrias em duas regiões do sudeste escravista ( 1825-1888). Dissertação de Mestrado. São Paulo: USP/FFLCH, 2008.
} 
ventre livre nascesse para ser titulo passo a presente. São Matheus, sete de setembro de mil oitocentos e oitenta e quatro. Abílio Viegas Martins, depois de ter aqui registrado, entreguei o original ao assistente Antônio Feldelis que recebeu a que aqui assino. Eu, Bernardino de Senna, tabelião, Que a escrevi e assino. Bernardino de Senna. Antônio Fidelis Cardoso. ${ }^{216}$

Registro de Carta de Liberdade conferido pelo doutor Graciano dos Santos Neves a sua escrava criola de nome Luzia. A presente é a carta de alforria de minha escrava Luzia e a faço pelo meu próprio punho em virtude de ter recebido da mãe da mesma escrava quantia de um conto, quatrocentos mil réis, pode pois a mesma, Luzia, gozar sem mais ônus de sua inteira e perfeita liberdade. São Matheus, doze de janeiro de mil oitocentos e setenta e cinco. Doutor Graciano dos Santos Neves. Escrevo que continha na dita carta, que registrei, ele me remeteu a presente e assino a rogo Horácio Henrique da Silva, por não saber escrever. São Matheus, seis de fevereiro de mil oitocentos e setenta e cinco. O tabelião Sabino José de Oliveira. ${ }^{217}$

Outra categoria de alforrias onerosas são as alforrias condicionais pagas, a exemplo da que se segue:

Registro de Carta de Liberdade da escrava Genoveva, como abaixo se declara. Declaro que recebi da escrava Genoveva, preta de nação mina, pertencente a muitíssima senhora Dona Ana Luisa Henrique de Paiva, conforme o ordeno que está na carta de quatorze de abril a quantia de cento e cinquenta mil réis para indenização por sua liberdade atendendo a serviços prestados pela mesma preta Genoveva com condições de continuar o seu serviço fazendo (ilegível) da dita senhora Dona Ana e por ser verdade passo a presente e por isso, assinada como administrador geral Manoel Monteiro Marque Ventura, reconheço verdadeiro, afirmo a supra. São Matheus, trinta e um de julho de mil oitocentos e setenta e cinco. Eu, Sabino José d Oliveira, tabelião, escrevi e assino na presente e a rogo. Nada mais tinha na dita carta que fielmente registrei e comigo assinou João Dias Lopes de Vasconcelos. São Matheus, trinta e um de julho de mil oitocentos e setenta e cinco. O tabelião. Sabino José de Oliveira. João Dias Lopes de Vasconcelos. ${ }^{218}$

As alforrias onerosas formam um conjunto de cartas com redações e argumentos muito variados, por isso devem ser agrupadas segundo a existência ou não de condição imposta e de pagamento, combinadas separadamente. Enidelce Bertin ${ }^{219}$ utiliza uma tipologia nessa direção.

\footnotetext{
${ }^{216}$ Cartório de $1^{\circ}$ Ofício de São Matheus - Espírito Santo, Livro 18 - Folha 31v.

${ }^{217}$ Cartório de $1^{\circ}$ Ofício de São Matheus - Espírito Santo, Livro 7 - Folha 26.

${ }^{218}$ Cartório de $1^{\circ}$ Ofício de São Matheus - Espírito Santo, Livro 7 - Folha 70.

219 BERTIN, Enidelce. Alforrias na São Paulo do século XIX: liberdade e dominação. São Paulo: Humanitas/USP/FFLCH, 2004, p. 82.
} 
Bertin acrescenta ainda, acerca da tipologia estabelecida em sua pesquisa sobre as alforrias na cidade de São Paulo no século XIX, uma diferença entre as alforrias gratuitas - aquelas que não tiveram qualquer ônus para o escravo, seja em pagamento ou em cumprimento de obrigação - e aquelas que denomina de alforrias incondicionais e não pagas (as quais inclui na categoria das onerosas, sendo que aparentam ser gratuitas já que são incondicionais e não pagas). Isso se deve ao fato de que nestas cartas de liberdade, o texto não esclarece se o senhor recebeu alguma coisa em troca (ônus em serviços ou pagamentos), diferentemente das incondicionais pagas em que o texto explica a forma como foi realizado o pagamento.

Outro autor, José Roberto Pinto de Góis, ao pesquisar as alforrias do Rio de Janeiro entre 1840 e 1871 , estabelece uma tipologia mais resumida, a qual "tem a vantagem de estabelecer a diferença entre as cartas pagas e as gratuitas, para, só depois tratar de seu caráter condicional (oneroso) ou não. Tal procedimento permite conhecer melhor, na caso das cartas compradas pelos próprios escravos, o grau e o tipo de sua inserção na vida econômica". 220

Para Góis, tanto as cartas gratuitas como as pagas (ou onerosas) podem, por sua vez, ser incondicional ou condicional, sendo que esta última é 'condicionada' ao ato de 'servir' ao senhor ou à 'outra condição'.

A classificação das diversas modalidades de alforrias é uma das partes da pesquisa que mais apresenta dificuldades para o estudioso do tema das manumissões.

Classificar as diversas modalidades de alforrias condicionais e mesmo as incondicionais, que emergem da documentação, não é tarefa fácil, visto que as interpretações dos textos estão sujeitas às diferentes possibilidades de leitura dos mesmos.

\footnotetext{
${ }^{220}$ GÓIS, J. Roberto Pinto de. Padrões de alforrias no Rio de Janeiro - 1840/1871. In: FRAGOSO, FLORENTINO, JUCÁ e CAMPOS (orgs.) Nas Rotas do Império. Vitória: EDUFES, 2006, p. 526.
} 


\subsection{As alforrias de São Mateus.}

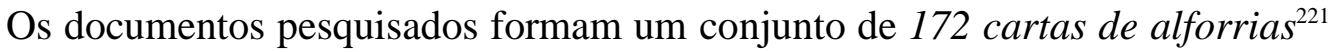
que correspondem a todas as encontradas para São Mateus no período de 1863 a 1888, ou seja, no último quartel da escravidão no Brasil, sendo 114 cartas concedidas para mulheres e 58 para homens. (v. Tabela 1)

\begin{tabular}{|c|c|c|}
\hline Sexo do & escravo Frequência & Percentual \\
\hline Mulheres & 114 & 66,3 \\
\hline Homens & 58 & 33,7 \\
\hline Total & 172 & 100,0 \\
\hline
\end{tabular}

Como em boa parte das regiões brasileiras, a década de 1870 foi a que mais forneceu alforrias em São Mateus (86 cartas - v. Tabela 2), correspondendo a um percentual de $50 \%$ das cartas obtidas. Em seguida vem a década de 1880, com 61 cartas fornecidas (35\%), sendo que na década de 1860 esse percentual foi muito baixo (12,8 $\%)$, correspondendo apenas a 22 cartas de alforrias.

Tabela 2: Registro das alforrias por décadas em São Mateus (1863-1888).

\begin{tabular}{lrrc}
\hline $\begin{array}{l}\text { Ano de } \\
\text { registro }\end{array}$ & Frequência & Percentual & Percentual Acumulado \\
\hline $1863-1869$ & 22 & 12,8 & 12,8 \\
$1870-1879$ & 86 & 50,0 & 62,2 \\
$1880-1888$ & 61 & 35,0 & 97,8 \\
Nada consta & 3 & 2,2 & 100,0 \\
Total & 172 & 100,0 & - \\
\hline
\end{tabular}

Fonte: Cartório de 1ㅇ. Ofício de São Mateus.

Sem querer esgotar o amplo leque de exemplos que podemos fornecer a partir da tipologia das alforrias, resumiremos a título de maior precisão, em seis modalidades principais as categorias de manumissões encontradas nos 172 documentos de alforria

${ }^{221}$ Estes documentos estão dispostos da seguinte forma: Livro 1 - 13 alforrias; Livro 2 - 18 alforrias; Livro 4 - 11 alforrias; Livro 5 - 12 alforrias; Livro 6 - 30 alforrias; Livro 7 - 13 alforrias; Livro 10 - 4 alforrias; Livro 11 - 7 alforrias; Livro 12 - 12 alforrias; Livro 15 - 13 alforrias; Livro 18 - 4 alforrias; Livro 19 -35 alforrias. 
pesquisados em São Mateus. Estas modalidades ou tipos expressam a forma de concessão da alforria. São elas:

Tabela 3: Tipos de cartas de alforria /Percentual das formas de concessão (1863-1888).

\begin{tabular}{lccc}
\hline Forma de Concessão & Frequência & Percentual & Percentual Acumulado \\
\hline Paga/onerosa & 67 & 39,0 & 39,0 \\
Incondicional (sem ônus) & 21 & 12,2 & 51,2 \\
Condicional & 19 & 11,0 & 62,2 \\
Via Judicial/protesto & 19 & 11,0 & 73,2 \\
Metade alforriada/coartação & 9 & 5,2 & 78,4 \\
Testamento/inventário/espólio & 6 & 3,5 & 82,0 \\
& & & \\
Nada Consta & 31 & 18,0 & 100,0 \\
Total & 172 & 100,0 & - \\
\hline
\end{tabular}

Fonte: Cartório de 1‥ Ofício de São Mateus.

No conjunto documental trabalhado (v. Tabela 3) podemos identificar, pelo menos, grosso modo, seis tipos de cartas de alforria, a saber: - 67 registros de cartas de liberdade vendidas pelos proprietários (as chamadas alforrias onerosas ou pagas); - 21 registros de cartas de liberdade concedidas "gratuitamente" (também chamadas de gratuitas ou incondicionais); - 19 registros de cartas de liberdade concedidas por via judicial; - 19 cartas condicionais (a qual estipula alguma condição para o seu alcance).

As alforrias condicionais são classificadas na categoria das onerosas por alguns estudiosos. Para o caso de São Mateus optamos por não incluí-las nessa classificação, porque em quase todos os documentos analisados só encontramos a referência à prestação de serviços ou nada constaram sobre isso, sendo que em apenas 3 delas foi estipulado valor a pagar; - 9 coartações/metade alforriada (2 coartações e 7 metade alforriada); e 6 alforrias via inventários/testamentos. Em 31 documentos não foi identificado o modo da concessão (nada constaram). Também foram identificadas algumas variáveis de escravos contidas nas cartas de liberdade, tais como sexo, idade, cor, profissão, etnia, dentre outras, as quais serão tratadas a seguir.

Dentro dessas seis modalidades, ainda se podem constituir subgrupos como: alforrias compradas com pagamento em dinheiro; alforrias compradas com pagamento em forma de prestação de serviços; alforrias compradas com pagamento em espécie; alforrias pagas com metade em dinheiro e metade prestação de serviços, dentre outros.

Devemos ainda ressaltar que optamos por não incluir as coartações na categoria das onerosas, agrupando-as aleatoriamente com as chamadas metade alforriada, por se 
tratarem de um numero muito reduzido de documentos (apenas 9 - mais adiante faremos algumas observações sobre essa forma de manumissão).

Os critérios utilizados para a classificação das cartas de liberdade de São Mateus, para agrupamento segundo modalidades específicas, baseou-se na observação das pesquisas de vários autores, dentre os quais, alguns já foram citados acima, que utilizaram critérios variados de classificação, a partir da bipolaridade tipológica das categorias onerosas/gratuitas.

Por se tratar de uma amostragem relativamente pequena de alforrias, nossa classificação na realidade é um referencial para comparações entre os padrões de alforria em diferentes regiões do país e aqueles registrados na Província do Espírito Santo, cujos diferenciais mais explícitos são os valores dos pagamentos e a forma (com prazos estipulados ou a vista, pagos pelo escravo ou por um terceiro), e a prestação de serviços por tempo determinado, para os casos principalmente das alforrias condicionais. Sem deixar de considerar as 31 alforrias que não deixaram indicações, mínimas que fossem, para definição da forma de concessão. Nestes casos os textos são muito formais, não detalhando nada, apenas que se tratava de uma carta de liberdade, indicando mais nomes de testemunhas, de tabeliães e datas.

Tabela 4: Tipos de cartas de alforria por sexo dos cativos em São Mateus (1863-1888).

\begin{tabular}{|c|c|c|c|c|c|c|}
\hline \multirow[t]{2}{*}{ Forma de concessão } & \multicolumn{3}{|c|}{ Sexo do escravo } & \multirow[b]{2}{*}{$\%$} & \multirow[b]{2}{*}{ Total } & \multirow[b]{2}{*}{$\%$} \\
\hline & Mulheres & $\%$ & Homens & & & \\
\hline Paga/onerosa & 41 & 36,0 & 26 & 44,8 & 67 & 39,0 \\
\hline Condicional & 13 & 11,4 & 6 & 10,3 & 19 & 11,0 \\
\hline Testamento/inventário/espólio & 4 & 3,5 & 2 & 3,4 & 6 & 3,5 \\
\hline Incondicional (sem ônus) & 17 & 14,9 & 4 & 6,8 & 21 & 12,2 \\
\hline Via Judicial/protesto & 14 & 12,3 & 5 & 8,6 & 19 & 11,0 \\
\hline Metade alforriada/coartação & 6 & 5,3 & 3 & 5,1 & 9 & 5,3 \\
\hline Nada Consta & 19 & 16,6 & 12 & 2,0 & 31 & 18,0 \\
\hline Total & 114 & 100,0 & 58 & 100,0 & 172 & 100,0 \\
\hline
\end{tabular}

Fonte: Cartório de 1‥ Ofício de São Mateus.

Sabemos que no período em que estas cartas foram registradas, muita coisa mudou em relação à composição da população escrava. O fim do tráfico transatlântico em 1850 significou uma reordenação de um mecanismo que não permitia o equilíbrio entre os sexos entre a população cativa. A nova configuração obtida a partir de então, consequiência da alteração dos preços dos escravos disponíveis no mercado interno e 
no tráfico, agora, interprovincial, embora implicando uma nova ordenação dessa população, não tirou das mulheres escravas o primeiro lugar na obtenção das alforrias. Nem o fim do tráfico, nem a aproximação do fim da escravidão influenciaram na primazia a estas na obtenção das alforrias.

Sendo assim, no conjunto documental estudado, as mulheres além de obterem a maioria das cartas em todas as categorias, representando um percentual de 66,3\% das alforrias contra 33,7 \% dos homens (v. Tabela 1), elas também se mantiveram à frente dos homens em números absolutos em todas as formas de concessão. (v. Tabela 4)

Devemos observar que, embora nas alforrias pagas ou onerosas elas representassem um percentual de 36,0\% (41 cartas - v. Tabela 4) das 114 cartas conquistadas por elas, contra 44,8\% (26 cartas) das 58 cartas conquistadas pelos homens, isto não quer dizer que os homens foram os mais beneficiados com as compras de alforrias: também nessa forma de concessão elas predominaram.

Nas alforrias incondicionais/sem ônus as mulheres alcançaram um grande número de alforrias (17 cartas) em relação aos homens (apenas 4), confirmando em termos numéricos, seu apreço pelos senhores proprietários, sendo que também nas cartas por via judicial elas conseguem a maioria esmagadora das alforrias (14 cartas), enquanto a dos homens estas somam-se 5.

\subsubsection{As alforrias onerosas, as condicionais e as coartações/metade alforriada.}

Durante todo o século XIX, houve a predominância das alforrias onerosas. A alta incidência de alforrias dessa categoria em todo o Oitocentos, e em todas as regiões do sudeste escravista, nos leva a crer na utilização da alforria não só enquanto tática para controle das ações escravas, mas enquanto objeto mercadológico para auxílio financeiro de proprietários em momentos de crise, podendo funcionar a alforria como capital ou como desencargo econômico.

Nas cartas de liberdade vendidas ou negociadas pelos proprietários ou compradas pelo escravo ou terceiros, classificadas na tipologia proposta para esse estudo de alforrias onerosas/pagas encontramos um percentual de 39,0 das cartas. (v. Tabela 4)

Neste conjunto documental, existem dados que possibilitam análises mais quantitativas sobre a escravidão em São Mateus, tendo em vista que as mesmas trazem os valores pagos pela liberdade dos (as) escravos (as) no decorrer do período estudado 
ou a condição do pagamento.

Além disto, essa documentação contém outros tipos de informações - tais como as formas de pagamento estabelecidas nas cartas, as quais podem ser agrupadas e comparadas com a realidade da escravidão na Província do Espírito Santo e também com a de outras regiões do país.

Analisando os dados sobre os valores pagos pelas cartas de liberdade de São Mateus por categorias, (v. Tabela 5) temos as seguintes situações da categoria das alforrias onerosas/pagas:

- Nesta categoria há o registro de 67 cartas de liberdade pagas, representando 39,0\% do total das manumissões, sendo que em 2 delas não consta o valor pago, embora nos documentos esteja explícito que foi pagamento em dinheiro e à vista;

- Em apenas 1 carta foi alcançado um valor superior a dois contos de réis (2:000\$000 rs.) e em outra um valor superior a 1:501\$000 (exatamente 1:600\$000 rs.), correspondendo a um percentual baixíssimo ( $0,6 \%$ do total);

- Do conjunto total, 5 cartas foram vendidas por até 200 mil réis (200\$000 rs.), representando também um percentual baixo (3,0\% do total), estando esta cotação, notadamente, com um valor mais accessível aos escravos. Não podemos esquecer que estamos tratando de uma região de economia que não se enquadra nos moldes das economias de exportação, tipo plantation, onde os plantéis são muito maiores; 
Tabela 5: Forma de concessão/ valor da alforria/ sexo dos escravos (1863-1888).

\begin{tabular}{|c|c|c|c|c|c|}
\hline Forma de Concessão & Valor da Alforria & $\begin{array}{l}\text { dos } \\
\text { M }\end{array}$ & $\begin{array}{c}\text { Escravos } \\
\mathrm{H}\end{array}$ & Total & $\%$ \\
\hline \multirow[t]{10}{*}{ Paga/onerosa } & Até 200 mil réis & 4 & 1 & 5 & 3,0 \\
\hline & 201-400 mil réis & 6 & 4 & 10 & 5,8 \\
\hline & 401-600 mil réis & 13 & 8 & 21 & 12,2 \\
\hline & 601-800 mil réis & 5 & 4 & 9 & 5,2 \\
\hline & 801-999 mil réis & 2 & 7 & 9 & 5,2 \\
\hline & 1 conto a $1 \$ 500$ mil réis & 8 & 1 & 9 & 5,2 \\
\hline & $\begin{array}{l}1 \text { conto e } 501 \text { mil réis a dois } \\
\text { contos }\end{array}$ & 1 & - & 1 & 0,6 \\
\hline & Acima de dois contos de réis & 1 & - & 1 & 0,6 \\
\hline & Nada Consta & 1 & 1 & 2 & 1,2 \\
\hline & Total & 41 & 26 & 67 & 39,0 \\
\hline \multirow[t]{6}{*}{ Condicional } & Até 200 mil réis & 1 & - & 1 & 0,6 \\
\hline & $601-800$ mil réis & 1 & - & 1 & 0,6 \\
\hline & 1 conto a $1 \$ 500$ mil réis & - & 1 & 1 & 0,6 \\
\hline & $\begin{array}{l}\text { Prestação de serviços sem valor } \\
\text { fixo }\end{array}$ & 8 & 4 & 12 & 6,9 \\
\hline & Nada Consta & 3 & 1 & 4 & 2,3 \\
\hline & Total & 13 & 6 & 19 & 11,0 \\
\hline \multirow[t]{4}{*}{ Testamento/inventário } & Até 200 mil réis & 1 & - & 1 & 0,6 \\
\hline & 201-400 mil réis & 1 & - & 1 & 0,6 \\
\hline & Nada Consta & 2 & 2 & 4 & 2,3 \\
\hline & Total & 4 & 2 & 6 & 3,5 \\
\hline \multicolumn{2}{|c|}{ Incondicional (sem ônus)Sem ônus } & 17 & 4 & 21 & 12,2 \\
\hline & Total & 17 & 4 & 21 & 12,2 \\
\hline \multirow[t]{5}{*}{ Via Judicial/protesto } & Até 200 mil réis & - & 1 & 1 & 0,6 \\
\hline & 201-400 mil réis & 2 & - & 2 & 1,2 \\
\hline & $\begin{array}{l}1 \text { conto e } 501 \text { mil réis a dois } \\
\text { contos }\end{array}$ & & 2 & 2 & 1,2 \\
\hline & Nada Consta & 12 & 2 & 14 & 8,0 \\
\hline & Total & 14 & 5 & 19 & 11,0 \\
\hline \multirow{6}{*}{$\begin{array}{l}\text { Metade } \\
\text { alforriada/Coartação }\end{array}$} & 201-400 mil réis & 1 & - & 1 & 0,6 \\
\hline & $601-800$ mil réis & - & 1 & 1 & 0,6 \\
\hline & 801-999 mil réis & - & 1 & 1 & 0,6 \\
\hline & $\begin{array}{l}\text { Prestação de serviços sem valor } \\
\text { fixo }\end{array}$ & 3 & 1 & 4 & 2,3 \\
\hline & Nada Consta & 2 & - & 2 & 1.2 \\
\hline & Total & 6 & 3 & 9 & 5,3 \\
\hline \multirow[t]{2}{*}{ Nada Consta } & Nada Consta & 19 & 12 & 31 & 18,0 \\
\hline & Total & 19 & 12 & 31 & 18,0 \\
\hline \multicolumn{2}{|l|}{ Total } & 58 & 114 & 172 & 100,0 \\
\hline
\end{tabular}

Fonte: Cartório de 1ํ. Ofício de São Mateus.

- Em 9 cartas encontramos os valores estipulados ente 1 conto e 1 conto e 500 mil réis (1:000\$000 e 1:500\$000 rs.), sendo 8 para mulheres e 1 para os homens, correspondendo a um valor significativo para os escravos, visto que se trata de uma 
região não abundante em formas alternativas de obtenção de capitais por parte dos escravos, completamente diferente do caso, por exemplo, de Minas Gerais no auge da mineração ou do Rio de Janeiro com suas formas urbanas de comércio ambulante;

- Em 49 cartas o valor da alforria variou entre 201 mil réis a 999 mil réis (201\$000 e $999 \$ 000$ rs.), constituindo a maior parcela das alforrias compradas.

Tabela 6: Valor das alforrias e ano da declaração (1860-1888).

\begin{tabular}{|c|c|c|c|c|c|c|c|c|c|c|c|c|}
\hline \multirow{2}{*}{$\begin{array}{l}\mathrm{ANO} \\
\text { DECL }\end{array}$} & \multicolumn{11}{|c|}{ VALOR DA ALFORRIA } & \multirow[t]{2}{*}{ TOTAL } \\
\hline & $\begin{array}{l}\text { Até200 } \\
\text { mil réis }\end{array}$ & $\begin{array}{l}201-400 \\
\text { mil réis }\end{array}$ & $\begin{array}{l}\text { 401-600 } \\
\text { mil réis }\end{array}$ & $\begin{array}{c}601-800 \\
\text { mil réis }\end{array}$ & $\begin{array}{l}801-999 \\
\text { mil réis }\end{array}$ & $\begin{array}{c}1 \text { conto a } \\
1 \$ 500 \\
\text { mil réis }\end{array}$ & $\begin{array}{l}1 \text { conto e } \\
501 \text { mil } \\
\text { réis a dois } \\
\text { contos }\end{array}$ & $\begin{array}{c}\text { Acima } \\
\text { de dois } \\
\text { contos } \\
\text { de réis } \\
\end{array}$ & $\begin{array}{l}\text { Prestação } \\
\text { de serviços } \\
\text { sem valor } \\
\text { fixo }\end{array}$ & $\begin{array}{l}\text { Sem } \\
\text { Ônus }\end{array}$ & $\begin{array}{l}\text { Nada } \\
\text { Consta }\end{array}$ & \\
\hline $1860-64$ & - & 1 & 1 & 1 & - & 1 & - & - & 1 & - & 2 & 7 \\
\hline $1865-69$ & - & 1 & - & - & - & 1 & - & - & 3 & 3 & - & 8 \\
\hline $1870-74$ & 2 & 4 & 2 & - & 1 & 1 & - & - & 2 & 4 & 17 & 33 \\
\hline $1875-79$ & 2 & - & 5 & 3 & 1 & 2 & 1 & - & 2 & 5 & 3 & 24 \\
\hline $1880-84$ & - & - & 4 & - & - & - & - & - & 2 & 4 & 4 & 14 \\
\hline $1885-88$ & 1 & 3 & 5 & 6 & 5 & - & - & - & - & 1 & 7 & 28 \\
\hline Não & & & & & & & & & & & & \\
\hline Consta & 3 & 5 & 4 & 1 & 3 & 5 & 2 & 1 & 6 & 4 & 24 & 58 \\
\hline Total & 8 & 14 & 21 & 11 & 10 & 10 & 3 & 1 & 16 & 21 & 57 & 172 \\
\hline
\end{tabular}

Fonte: Cartório de 1ํ. Ofício de São Mateus.

Neste conjunto documental de 172 cartas de liberdade, encontramos 78 cartas $^{222}$ com valores estipulados, independente da classificação ou da tipologia da alforria, incluindo aí as coartações, as condicionais pagas em dinheiro e as resultantes de processos judiciais em que o juiz estipulou o valor a ser pago pelo escravo. (v. Tabela 6) Das 172 cartas pesquisadas, em 57 cartas não constam dados referentes a pagamentos, em 16 os dados se referem à prestação de serviços sem valores fixos, e em 21 documentos não há referência a ônus para os escravos (são as incondicionais ou gratuitas). Dessas 78 cartas com valores estipulados, 13 não entram na categoria das onerosas/pagas (que totalizam 67 cartas), pois pertencem a outras categorias, restando 65 cartas das onerosas/pagas com valores definidos e 2 que não constam o valor, embora sejam classificadas no conjunto das onerosas/pagas.

222 (Total: $8+14+21+11+10+10+3+1=78$ cartas) 
Analisando os dados sobre os valores pagos pelas cartas de liberdade de São Mateus por décadas, (v. Tabela 6) temos as seguintes situações:

a) Década de 1860: temos o registro de 6 cartas de alforrias pagas.

- 1860 a 1864: Neste período há a declaração de 4 cartas de liberdade pagas, com valores estipulados entre $201 \$ 000$ e 1:000\$000 rs. (201 mil réis e 1 conto de réis), de 2 cartas não constando o valor pago pela alforria e de 1 referindo-se à prestação de serviços sem valor fixo;

- 1865 a 1869: Neste período há a declaração de apenas 2 cartas de liberdade pagas, uma com valor entre 201 mil réis e 400 mil réis (201\$000 e $400 \$ 000$ rs.) outra com valor entre 1 conto de réis e quinhentos mil réis. Outras 3 cartas se referem à prestação de serviços sem valor fixo (condicionais) e em duas 2 não há referência à cobrança de ônus (incondicionais).

b) Década de 1870: registra-se a ocorrência de 24 cartas de liberdade pagas.

- 1870 a 1874: há o registro de 10 cartas pagas com valores que vão até 1:000\$000 rs. (um conto de réis); em 17 cartas não consta sobre valores; 2 cartas de referem à prestação e serviços (condicionais) e 4 são sem ônus (incondicionais).

- 1875 a 1879: há o registro de 14 cartas pagas com valores que vão até 1:000\$000 rs. (1 conto de réis); em 2 cartas não consta sobre valores; 2 se referem à prestação de serviços (condicionais) e 5 são sem ônus (incondicionais).

c) Década de 1880: Período que reúne também um maior número de registros dessa categoria de manumissão, ou seja, 24 cartas de liberdade pagas.

- 1880 a 1884: há apenas 4 alforrias pagas encontradas nesse período, com valores estipulado entre $401 \$ 000$ e $600 \$ 000$ rs. (401 mil réis e 600 mil réis). Em 2 cartas há a referência à prestação de serviços sem valores fixos; em 4 não consta o valor e em outras 4 não há referência a ônus.

- 1885 a 1888: foram encontradas 20 alforrias pagas neste período.

Observamos que, um total de 15 dessas cartas foram negociadas por um mesmo proprietário de escravos - o coronel Domingos Rocha da Silva Rios, praticamente às vésperas da abolição, sendo as mesmas vendidas a preços relativamente altos nos meses de janeiro e fevereiro de 1888 . 
d) Não consta o ano da declaração da alforria: em 24 cartas.

Todavia constam valores que vão até:

- acima de 2:000\$000 rs. (dois contos de réis)/1 carta;

- entre 1:501\$000 e 2:000\$000 rs./ 2 cartas;

- entre 1:000\$000 e 1:500\$000 rs./ 5 cartas.

- As 16 cartas restantes variaram até $999 \$ 000$ rs. (999 mil réis).

As alforrias condicionais.

Trata-se de uma categoria polêmica, a qual é incluída por grande parcela dos pesquisadores, separadamente do rol das onerosas/pagas, como já foi ressaltado. Alguns pesquisadores preferem incluí-las no rol das gratuitas, para os casos em que não há ônus estipulado em termos monetários, havendo apenas outras condições, como por exemplo, a de 'servir ao senhor' por tempo pré-determinado. Entre as encontradas no conjunto documental estudado (19 cartas), 12 se referem à prestação de serviços sem valor fixo e em 4 não constam a condição exigida para a alforria, embora fazem referências 'à exigências'. Nas outras três cartas restantes, é estipulado o pagamento de 200 mil réis (200\$000 rs.) em uma, entre 601 e 800 mil réis (601\$000 e 800\$000 rs.) para a outra, enquanto que para a terceira é estipulado o alto valor entre 1:000\$000 e 1: $500 \$ 000$ rs. (v. Tabela 5)

\section{As coartações/metade alforriada.}

As diferenças entre as cartas coartadas e as compradas e condicionadas à prestação de serviços, pagamentos em espécie ou em moeda, por tempo determinado, são muito sutis, pois muitas cartas de alforria compradas eram parceladas assim como as coartações. Nas coartações, na maioria dos casos o cativo entregava um valor de entrada e pagava o restante em cotas, cujo prazo para o pagamento dessas poderia variar entre dois a vários anos (sete, oito ...), sendo mais comum o parcelamento em quatro anos (daí a expressão 'quartado') ${ }^{223}$, o mesmo tempo estabelecido para a maioria dos

223 O mais usual é o termo 'coartado' que significa estreitar, abreviar o tempo da alforria. 
casos de alforrias concedidas mediante a prestação de serviços por tempo determinado (das alforrias condicionais).

Entre as categorias das alforrias condicionais e das onerosas pode ser extraído, basicamente, quatro tipos de condicionalidade: as formas parceladas de pagamento, denominada no documento como coartação; a prestação de serviços ou o pagamento em espécie; o pagamento feito a vista pelo próprio manumisso, designada como 'autopagamento' e o pagamento realizado por 'terceiros'. Há que ressaltar ainda que, em muitos casos, as condições anteriormente especificadas poderiam vir combinadas. ${ }^{224}$

Mesmo considerando que a coartação seja uma forma de alforria condicional, paga de forma parcelada, ou mesmo que seja uma modalidade à parte, não podemos fazer muitas afirmações sobre o assunto, para os casos de São Mateus, com base em um conjunto documental em parte restrito - 172 cartas - onde identificamos apenas 2 casos destas. Os outros 7 casos identificados nos documentos como metade alforriada, foram agrupados no conjunto das coartações devido ao fato de ambas constituírem casos peculiares de concessão de alforrias. Todavia, devemos ressaltar que os casos de coartações sempre têm a sua importância para o estudo das relações escravistas devido à sua raridade, principalmente no Espírito Santo. (v. transcrições em ANEXO 3)

Novamente neste conjunto de alforrias as mulheres são maioria, com 6 cartas ou $67 \%$ do total, ao passo que os homens obtêm apenas 3 cartas $(33,0 \%)$ desse conjunto. (v. Tabela 7)

Tabela 7: Metade alforriada/ coartações por sexo dos cativos em São Mateus (1863-1888).

\begin{tabular}{lcc}
\hline $\begin{array}{l}\text { Sexo do } \\
\text { escravo }\end{array}$ & $\begin{array}{c}\text { Forma de concessão } \\
\text { Metade alforriada/ Coartação }\end{array}$ & Total \\
\hline Mulheres & 6 & 6 \\
Homens & 3 & 3 \\
Total & 9 & 9 \\
\hline Fonte: Cartório de 1ํ. Ofício de São Mateus. &
\end{tabular}

Nesta perspectiva de pequena amostragem, e mesmo utilizando-se de séries documentais mais numerosas, "a coartação representa modalidade de alforria

\footnotetext{
${ }^{224}$ GONÇALVES, Andréia L. As margens da liberdade: alforrias na comarca de Ouro Preto (1808/1870).
} São Paulo: USP, 2000 (Tese de doutorado), p.272. 
pouquíssimo estudada entre nós, e ao que tudo indica, pouco difundida no interior da América portuguesa, mostrando-se mais usual na capitania de Minas Gerais". ${ }^{225}$

Segundo Mello e Souza é de suma importância salientar a respeito das coartações, que estas são alforrias condicionais de características e traços muito peculiares, e de forma até ambígua, classificando-as às vezes como uma categoria à parte, e noutras não, ao lado das manumissões. A pesquisadora nos informa que nas Minas “o hábito de coartar os escravos foi sendo paulatinamente mais comum do que alforriá-los, correspondendo possivelmente a uma estratégia senhorial com vistas ao aumento de seus rendimentos". ${ }^{226}$

Esse este tipo de alforria se dava quando o cativo pagava por sua liberdade em parcelas, contratando antecipadamente o valor a ser pago. As parcelas podiam ou não ser fixadas previamente, estando a alforria condicionada à morte do proprietário, à continuidade de prestação de bons serviços e só era entregue após o pagamento completo do valor do escravo.

\begin{abstract}
Os coartamentos contribuíram em muito para complicar uma estrutura social já bastante complexa, abrindo vastas áreas de indefinição entre o cativeiro e a liberdade. Se era comum reconduzir os forros ao cativeiro, muito mais fácil seria fazê-lo com coartados: as partes nunca concordavam quanto ao montante das dívidas e das cláusulas anteriormente fixadas, embaralhavam os prazos, manipulavam as datas. Por outro lado, a confusão beneficiava também os escravos em vias de se alforriarem [...] neste sentido, o coartamento integrou as estratégias que os escravos souberam desenvolver de forma paciente, corajosa e, não raro, malandra. ${ }^{227}$
\end{abstract}

Outro autor, Eduardo França Paiva, ao pesquisar os testamentos post-mortem da Comarca do Rio das Velhas, também em Minas Gerais, afirma que "entre as várias formas de alforria existentes nas Minas Gerais do século XVIII, uma merece ser destacada: a coartação. Tratava-se, grosso modo, do pagamento parcelado da manumissão, podendo o coartado se ausentar do domínio senhorial durante anos

\footnotetext{
${ }^{225}$ SOUZA, Laura de Mello e. Coartação - problemática e episódios referentes a Minas Gerais no século XVIII. In: SILVA, Beatriz Nizza (org.) Brasil - Colonização e escravidão. R.J.: Nova Fronteira, 1999, p. 280. A pesquisadora nos informa que Schwartz menciona de passagem a coartação para mostrar a existência de variações e nuanças no seio da condição escrava; dentre tais variações contava a do escravo coartado, ou seja, aquele que conseguira o direito, 'expresso por seu proprietário em testamento ou outro documento, de pagar pela própria alforria, permitindo-lhe certa mobilidade de movimentos'.

${ }^{226}$ SOUZA, Laura de Mello e. Norma e Conflito - Aspectos da História de Minas no século XVIII. B.H: Ed. da UFMG/S.P.:Humanitas, 2006, p.159.

${ }^{227}$ Op. cit., p. 169.
} 
seguidos". No contexto mineiro dos Setecentos era "uma prática recorrente, mas muito pouco conhecida pela historiografia brasileira sobre a escravidão". ${ }^{228}$

França Paiva faz um levantamento dos escravos coartados, afirmando existir em Minas "uma tendência entre os senhores que adotaram as coartações, em valorizá-las em detrimento das alforrias" e que a própria quantidade destas "acertadas durante todo o século XVIII é um indicativo da boa aceitação delas, tanto por parte dos senhores quanto por parte dos escravos". ${ }^{229}$

Segundo o autor, nas Minas boa parcela dos libertos "pagou sua libertação em pó de ouro e ao preço de mercado, pagando também em trabalho, em serviços prestados à exaustão. Libertaram-se e, imediatamente, trataram de tornar-se proprietários de escravos, buscando assim, atenuar o estigma que carregavam na 'condição' e na 'qualidade' que possuíam, como se dizia na época". ${ }^{230}$ Por se tratar de uma economia dinâmica, maiores foram as oportunidades de obtenção dos valores pagos nas alforrias

No contexto das Minas Gerias do século XVIII, "num período de crise econômica, a mão-de-obra [escrava] transformava-se em encargo insustentável, acarretando a sua libertação imediata”. ${ }^{231}$

A 'carta de corte' era o documento que permitia a mobilidade do cativo, também considerado uma espécie de 'escravo de ganho', sendo adquirido por este só após o pagamento integral do seu valor. ${ }^{232}$

\footnotetext{
${ }^{228}$ PAIVA, Eduardo França. Coartações e alforrias nas Minas Gerais do século XVIII: as possibilidades de libertação escrava no principal centro colonial. Revista de História, versão impressa ISSN0034-890g n.133, São Paulo dez. 1995.

${ }^{229} \mathrm{O}$ autor encontrou coartações em 143 testamentos dos 357 pesquisados, resultando em 278 escravos beneficiados. PAIVA, Eduardo França. Escravos e libertos nas Minas Gerais do século XVIII: estratégias de resistência através dos testamentos. São Paulo: Annablume, 2a . ed., 2000, p. 84 - 85.

${ }^{230}$ PAIVA, Eduardo França. Escravidão e universo cultural na colônia. Minas Gerais, 1716-1789. B.H.: Ed. UFMG, 2001, p. 213.

${ }^{231}$ PAIVA, Eduardo França. Escravos e libertos nas Minas Gerais do século XVIII: estratégias de resistência através dos testamentos. São Paulo: Annablume, 2a . ed. ,2000, p. 21. No 'Prefácio à Segunda Edição' deste livro, Carla M. J. Anastasia elucida que 'à idéia estabelecida de que a sociedade mineira era mais democrática do que as outras sociedades coloniais, Eduardo Paiva contrapõe a de que as alforrias aparecem tanto como uma forma de coerção quanto como de resistência, ao serem percebidas diferentemente pelos senhores e pelos escravos. Ao suposto que o grande volume de alforrias derivava da crise da economia mineradora, o autor apresenta o da relação das manumissões com a vigorosa diferenciação econômica nas áreas urbanas coloniais mineiras, o que explicaria a generalização das coartações, um tipo de manumissão paga parceladamente pelo escravo ou por terceiros".
}

232 Transcrição de uma das duas coartações encontradas no conjunto da documentação: (Livro 1, folha 142, data: 23/01/1867): Lancamento de huma Carta de liberdade que me foi apresentada pelo Capitão Jose Affonco Martins como se segue. Digo Eu João das Chagas abaixo assignado que sou senhor e possuidor de todos os meus bens que me ficarão por minha meação por fallecimento de minha mulher Adriana Maria Alves livres e dezembargados assim bem hum escravo de nome Francisco, cujo escravo que já hé coartado da metade de sua avaliação por morte de sua senhora, e como tem sofrido alguns 
Podemos observar que as cartas de alforrias apresentam uma grande diversidade de casos e muitas peculiaridades, demonstrando uma complexidade na relação entre senhores e escravos.

Nas manumissões inseridas na perspectiva de acordo entre senhor e escravo, a exemplo das coartações, destaca-se também os casos de metade alforriada ${ }^{233}$, em que o escravo recebeu ou negociou apenas metade de sua alforria (50\% da alforria). Quando o escravo não possuía a quantia da qual precisava para obter sua alforria, era comum libertar o escravo pela metade, numa quarta parte dentre outras. Para as alforrias só encontramos documentos que se referiam à metade alforriada, a exemplo do escravo José, cujo valor, estipulado em 500\$000 rs., foi "proveniente da metade de sua liberdade, ficando o mesmo sujeito a feitorar por dois anos para que possa, então, receber sua carta de liberdade". ${ }^{234}$

Apesar de se tratar de uma pequena amostra, torna-se interessante uma rápida análise comparativa desse tipo de manumissão, pois estes casos nos proporcionam uma idéia mais precisa acerca dos significados da liberdade para os cativos e libertos, assim como nos casos de compra e venda de escravos (como foi mostrado no capítulo anterior) em que se negociava 'partes' do escravo, tais como a quinta parte, a terça parte, a metade dentre outras partes, gerando situações extremamente peculiares.

Os pagamentos para a metade da alforria (assim como para as alforrias 'integrais') poderiam ser efetuados em forma de prestação de serviços (3 casos na documentação pesquisada), com pagamento em dinheiro (4 casos), sendo estes valores

achaques, e sofre, que tome sumarios cuidado dos mesmos achaques, e atem sendo isto não ser fingido a mais de seis annos, e por bons serviços desde [ilegivel] que que tem servido a seos senhores passo esta Carta de liberdade passa de hoje em diante gosar de sua liberdade como de ventre livre nacesse sem constrangimento algum e por morte minha não podera os meos interessados se opor sobre esta mesma liberdade e o senhor escrivão Henrique para lançar no livro de Notas e entregar esta ao mesmo ditto escravo Francisco como senhorio que foi me assigno commo acostumado São Matheos trinta e hum de Desembro de mil oito centos sessenta eseis $=$ Eu João Jose das Chagas = testemunha[ilegível] Affonço Martins = testemunha Manoel Jose Ricardo Muricy [ilegivel]dusentos = pagou dusentos reis $S$ Matheus desenove de Janeiro de mil Oito centos sessenta e sete = F H de Macedo e mais nada continha [ilegivel] dita carta que aqui fielmente copiei, depois, do que entregui ao mesmo Capitão Affonço sendo tambem aqui assignado comigo Bernard.no de Senna Tabellião que o escrevi aos vinte hum de Janeiro de mil oito centos sessenta e sete.Bernardino de Senna. Je. Affonço Martins.

${ }^{233}$ Esta modalidade de alforria - metade alforriada (07 casos) - não faz parte do conjunto das coartações. As duas modalidades (coartação e metade alforriada) foram reunidas no mesmo bloco por se constituírem pouquíssimos casos em termos numéricos.

${ }^{234}$ Livro 15 , folha 121 v, data do registro: $12 / 08 / 1882$. 
variados entre 201 e $999 \$ 000$ rs. ${ }^{235}$ Em 2 casos não consta o valor recebido ou a forma de pagamento.

\subsubsection{As alforrias incondicionais.}

Retornando à análise da Tabela 5, podemos observar que as alforrias condicionais (19 cartas) e as incondicionais/sem ônus (21 cartas) possuíram, no período estudado, quase a mesma proporção em termos numéricos. Na última década do escravismo as alforrias incondicionais mantiveram uma porcentagem mais ou menos proporcional às décadas anteriores, enquanto que as alforrias onerosas aumentaram significativamente.

Constatou-se que, para o período em estudo, as mulheres foram as mais beneficiadas em São Mateus, assim como em todo o sudeste escravista na segunda metade do século XIX, com alforrias incondicionais não-pagas/sem ônus, sendo que na documentação pesquisada, 17 cartas foram concedidas para estas e 4 para homens. Embora representem um percentual de apenas 12,2 do total das alforrias, as alforrias "gratuitas" ou incondicionais/sem ônus cresceram gradativamente ao longo da segunda metade do Oitocentos, ocasionando uma eventual queda percentual das onerosas. (v. Tabela 8)

Tabela 8: Valor pago pelas alforrias e ano de registro (1863-1888).

\begin{tabular}{|c|c|c|c|c|c|c|c|c|c|c|c|c|}
\hline \multicolumn{13}{|l|}{$\overline{\mathrm{ANO}}$} \\
\hline \multirow[t]{2}{*}{ REG } & \multicolumn{12}{|c|}{ VALOR DA ALFORRIA } \\
\hline & $\begin{array}{l}\text { Até } 200 \\
\text { mil réis }\end{array}$ & $\begin{array}{l}\text { 201-400 } \\
\text { mil réis }\end{array}$ & $\begin{array}{c}401-600 \\
\text { mil réis }\end{array}$ & $\begin{array}{r}601-800 \\
\text { mil réis }\end{array}$ & $\begin{array}{c}801-999 \\
\text { mil réis }\end{array}$ & $\begin{array}{l}1 \text { conto a } \\
1 \$ 500 \\
\text { mil réis }\end{array}$ & $\begin{array}{l}1 \text { conto } \\
\text { e } 501 \text { mil } \\
\text { réis a } \\
\text { dois } \\
\text { contos }\end{array}$ & $\begin{array}{l}\text { Acima } \\
\text { de dois } \\
\text { contos } \\
\text { de réis }\end{array}$ & $\begin{array}{l}\text { Prestação } \\
\text { de serviços } \\
\text { sem valor } \\
\text { fixo }\end{array}$ & $\begin{array}{l}\text { Sem } \\
\text { ônus }\end{array}$ & $\begin{array}{l}\text { Nada } \\
\text { Consta }\end{array}$ & Total \\
\hline $1863 /$ & & & & & & & & & & & & \\
\hline $\begin{array}{l}1864 \\
1865 /\end{array}$ & - & - & 1 & 1 & - & - & - & 1 & 1 & 1 & 3 & 8 \\
\hline $\begin{array}{l}1869 \\
1870 /\end{array}$ & - & 3 & - & - & - & 1 & 1 & - & 4 & 3 & 2 & 14 \\
\hline $\begin{array}{l}1874 \\
1875 /\end{array}$ & 2 & 5 & 2 & - & 1 & 4 & - & - & 5 & 5 & 24 & 48 \\
\hline $\begin{array}{l}1879 \\
1880 /\end{array}$ & 4 & 3 & 6 & 2 & 1 & 4 & 2 & - & 3 & 6 & 7 & 38 \\
\hline $\begin{array}{l}1884 \\
1885 /\end{array}$ & 1 & - & 7 & - & 3 & 1 & - & - & 3 & 5 & 9 & 29 \\
\hline $\begin{array}{l}1888 \\
\text { Não }\end{array}$ & 1 & 3 & 5 & 7 & 5 & - & - & - & - & - & 12 & 32 \\
\hline Consta & 1 & - & 1 & - & - & - & - & - & - & 1 & - & 3 \\
\hline Total & 8 & 14 & 21 & 11 & 10 & 10 & 3 & 1 & 16 & 21 & 57 & 172 \\
\hline
\end{tabular}

Fonte: Cartório de 1o. Ofício de São Mateus.

\footnotetext{
235 A faixa dos preços das alforrias dos escravos com a metade alforriada (4 cartas) foram: uma entre
} 201- 400\$000 rs.; duas entre 601-800\$000 rs.; e outra entre 801- $999 \$ 000$ rs. 
Pela Tabela 8 podemos observar que o maior número de alforrias incondicionais/sem ônus foi concedido na década de 1870 (11 cartas: 5 entre 1870/74 e 6 entre 1875/79), caindo esse para apenas 5 cartas na década seguinte.

Através da concessão de alforrias incondicionais, os senhores demonstravam a dependência ao sistema escravista, a qual era dissimulada com chavões do tipo sentimentalista e humanitário, como se vê nestas cartas de liberdade, onde os motivos alegados aparecem como "recompensa aos bons serviços", "bons e fiéis serviços", "liberdade plena e gratuita", "justa pretensão da mesma", dentre outros. Muitas vezes, por trás desse gesto aparentemente "nobre e generoso" dos senhores, havia a imposição explícita ou implícita de diversas exigências e pré-condições para a obtenção da liberdade total e plena dos escravos, a exemplo das registradas nas cartas condicionais.

\title{
4.3.3. As cartas por via judicial.
}

As cartas por via judicial são resultantes de conflitos entre senhores e escravos, os quais necessitaram da interferência do poder público para sua solução, mediante decisão da justiça. A prática de recorrer a ações de liberdade pode ser explicada pela presença da legislação ibérica no Brasil, assim como em outros países colonizados pela Espanha. Estudos atuais demonstram que a legislação e as possibilidades de acesso à justiça por parte dos escravos, tiveram importante papel a partir dos séculos XVIII e XIX em vários países escravocratas das Américas e da Europa. ${ }^{236}$ Muitos escravos conseguiram levar sua queixa aos tribunais ou ao rei, conseguindo resultados positivos em vários casos.

Segundo Grinberg,

\begin{abstract}
que essas ocorrências, transformadas em conflitos, tenham sido em toda parte levadas à órbita estatal, ainda que muitas vezes através de apelos extrajudiciais, é da maior importância. Diferentemente dos casos de compra de alforria em que escravos e senhores resolvem, ainda que nem sempre pacificamente, suas contendas em âmbito privado, as ações de liberdade, qualquer que tenha sido o país onde tenham ocorrido, demonstram a relevância da definição do status jurídico e político [...]. ${ }^{237}$
\end{abstract}

\footnotetext{
${ }^{236}$ GRINBERG, Keila. Alforria, Direito e Direitos no Brasil e nos Estados Unidos. Estudos Históricos, Rio de Janeiro, n. 27, 2001, p. 63-83.

${ }^{237}$ Ibidem, p. 68.
} 
Frente a tal situação, as ações de liberdade no Brasil, resultante de conflitos que acabaram nos tribunais, foram produtos de discussões em torno da propriedade escrava, versando mais sobre a questão da propriedade e não da liberdade. Sendo assim, em termos jurídicos, os casos mais comuns no Brasil dizem respeito a duas situações: quando o escravo reivindicava o direito de receber a carta prometida pelo seu senhor, fazendo com que os juízes ancorassem na questão do direito de doações, ou quando o escravo reclamava por direito de compra e venda de sua alforria, procurando os juízes nestes casos, legitimar uma transação comercial.

$\mathrm{Na}$ realidade, os escravos que tentavam obter a liberdade por via judicial, ficavam mais sujeito à ação dos juízes, cuja decisão dos processos tinham nas mãos, tendo estes que se basear nas suas próprias convicções para sentenciar cada caso.

Tabela 9: Cartas de Liberdade por via Judicial/ protesto - São Mateus (1866/1885).

\begin{tabular}{|c|c|c|c|c|}
\hline Data & $\begin{array}{l}\text { Nome } \\
\text { Escravo }\end{array}$ & $\begin{array}{l}\text { Senhor } \\
\text { Proprietário }\end{array}$ & $\begin{array}{l}\text { Decisão } \\
\text { do Processo }\end{array}$ & $\begin{array}{l}\text { Juiz } \\
\text { Responsável }\end{array}$ \\
\hline $24 / 09 / 1873$ & Veridiana & $\begin{array}{lr}\text { Manoel } & \text { Ignácio } \\
\text { das } & \text { Chagas } \\
\text { (inventário) }\end{array}$ & "ex-ofício" & $\begin{array}{l}\text { Luis José dos } \\
\text { Santos Guimarães/ } \\
\text { Cap. (suplente) }\end{array}$ \\
\hline $27 / 05 / 1874$ & Francisca & $\begin{array}{l}\text { Rosa Benedita } \\
\text { Moreira }\end{array}$ & "em favor" & $\begin{array}{l}\text { João Francisco } \\
\text { Poggi de Figueiredo } \\
\text { / Dr. }\end{array}$ \\
\hline 03/10/1874 & Felisarda & $\begin{array}{l}\text { Eduardo Cardoso } \\
\text { Porto }\end{array}$ & "a favor" & $\begin{array}{l}\text { Antônio José Nunes } \\
\text { Cardoso }\end{array}$ \\
\hline 1874 & Maria & $\begin{array}{l}\text { Sebastião José de } \\
\text { Amorim }\end{array}$ & "em favor" & $\begin{array}{l}\text { João de Jesus } \\
\text { Silvares Júnior/ Pe }\end{array}$ \\
\hline 1874 & Joaquina & $\begin{array}{l}\text { Sebastião José de } \\
\text { Amorim }\end{array}$ & “em favor” & $\begin{array}{l}\text { João de Jesus } \\
\text { Silvares } \\
\text { Júnior/ Pe. }\end{array}$ \\
\hline 1874 & Anastácia & $\begin{array}{l}\text { Sebastião José de } \\
\text { Amorim }\end{array}$ & “em favor" & $\begin{array}{l}\text { João de Jesus } \\
\text { Silvares } \\
\text { Júnior/ Pe. }\end{array}$ \\
\hline 1874 & Catharina & $\begin{array}{l}\text { Sebastião José de } \\
\text { Amorim }\end{array}$ & “em favor” & $\begin{array}{l}\text { João de Jesus } \\
\text { Silvares Júnior/ Pe. }\end{array}$ \\
\hline 1874 & Luíza & $\begin{array}{l}\text { Sebastião José de } \\
\text { Amorim }\end{array}$ & "em favor" & $\begin{array}{l}\text { João de Jesus } \\
\text { Silvares } \\
\text { Júnior/ Pe. }\end{array}$ \\
\hline $21 / 09 / 1875$ & Camila & $\begin{array}{l}\text { Francisco José da } \\
\text { Silva }\end{array}$ & "em favor" & $\begin{array}{l}\text { Francisco Rodrigues } \\
\text { Sette Filho / Dr. }\end{array}$ \\
\hline 14/02/1876 & Maria & $\begin{array}{l}\text { Clemente Peixoto } \\
\text { Silva }\end{array}$ & "a favor" & $\begin{array}{l}\text { Francisco Rodrigues } \\
\text { Sette Filho / Dr. }\end{array}$ \\
\hline $18 / 05 / 1876$ & Honório & Não consta & "a favor" & $\begin{array}{l}\text { Francisco Rodrigues } \\
\text { Sette Filho / Dr. }\end{array}$ \\
\hline $16 / 12 / 1876$ & Eugênio & Não consta & "a favor" & $\begin{array}{l}\text { Sebastião } \\
\text { Barbosa/Te. }\end{array}$ \\
\hline
\end{tabular}




\begin{tabular}{|c|c|c|c|c|}
\hline $28 / 07 / 1878$ & Lucas & $\begin{array}{l}\text { Maria Benedicta } \\
\text { Martins }\end{array}$ & "favorável" & $\begin{array}{l}\text { Francisco Vicente } \\
\text { de Farias (suplente) }\end{array}$ \\
\hline $19 / 10 / 1878$ & Pedro & $\begin{array}{l}\text { Eduardo dos } \\
\text { Santos Porto }\end{array}$ & “1:600\$000" & $\begin{array}{l}\text { Severino P. Amaral } \\
\text { Brandão/ Pe. }\end{array}$ \\
\hline 08/03/1880 & Idalina & Não consta & "favorável" & $\begin{array}{l}\text { Antonio José Vieira } \\
\text { de Faria/ Alferes }\end{array}$ \\
\hline 18/10/1882 & Guilhermina & Não consta & "a favor" & $\begin{array}{l}\text { Antonio Martins de } \\
\text { Miranda/Dr. }\end{array}$ \\
\hline 06/06/1881 & Faustina & $\begin{array}{l}\text { Adeodato } \\
\text { Antonio } \\
\text { Santos }\end{array}$ & “em favor" & $\begin{array}{l}\text { Lourenço Bernardo } \\
\text { Vieira/Cap. }\end{array}$ \\
\hline $21 / 04 / 1883$ & $\begin{array}{l}\text { Juliana / } 55 \\
\text { anos }\end{array}$ & Não consta & "a favor" & $\begin{array}{l}\text { Lourenço Bernardo } \\
\text { Vieira }\end{array}$ \\
\hline $22 / 01 / 1884$ & Felicíssimo & Não consta & "a favor" & $\begin{array}{l}\text { Lourenço Bernardo } \\
\text { Vieira }\end{array}$ \\
\hline
\end{tabular}

Fonte: Cartório de 1ํ. Ofício de São Mateus. Ver transcrições em Anexo 3.

Os dados constantes na Tabela 9 apresentam algumas peculiaridades:

1. No conjunto desse tipo de manumissão (um total de 19 cartas), não consta o nome do proprietário do escravo em 6 registros, ou seja, o nome desses só consta em 13 cartas.

2. Constatamos que em apenas 1 carta a decisão do processo estipula o valor a pagar: uma carta referente ao escravo Pedro (1878), constando "1:600\$000". Nos demais registros a decisão do processo aparece com as seguintes expressões: "a favor", "em favor" ou "favorável" (17 registros) ao escravo e "ex-oficio" (01 registro);

3. Somente em um registro consta a idade do (a) alforriado (a): Juliana/55 anos;

4. Também nesta categoria de manumissão a maioria dos cativos alforriada é do sexo feminino: 14 cartas de liberdade referem-se às mulheres (74,0\%) e 5 aos homens $(26,0 \%)$;

5. Acerca do juiz responsável pelo processo (no nível Municipal), observamos que todos os registros consta o nome do mesmo, e que estes somam 11 nomes diferentes (num período de 11 anos), evidenciando uma grande alternância no judiciário da época; fato este apontado em diversos relatórios dos presidentes da província no período referido.

6. Esse tipo de manumissão apresenta a seguinte proporção por décadas: década de $1870=14$ cartas; década de $1880=5$ cartas. Não encontramos cartas via judicial da década de 1860 . 
A historiografia mais recente sobre a escravidão no Brasil tem lançado novas questões sobre a temática da justiça e do direito escravo. As reivindicações formais por liberdade tem sido analisadas, associadas a noções de cidadania e justiça, sem perder de vista as contradições da escravidão. Sob essa perspectiva e, observando o caráter das cartas de alforria conquistadas por via judicial em São Mateus, pensar os problemas enfrentados pelos juízes e/ou homens de justiça, com o aumento do tráfíco interprovincial, permite entender em que medida os casos individuais teriam contribuído para a formação das leis que foram surgindo a partir da segunda metade do século XIX.

\subsection{As variáveis nas cartas de liberdade.}

\subsubsection{Gênero e idade.}

Conforme já observamos anteriormente, as mulheres escravas constituem o maior número no conjunto dos cativos de São Mateus que conquistaram cartas de liberdade no período entre 1863 e 1888 (v. Tabela 10), representando um percentual de $66,3 \%$ do total das alforrias, contra $33,7 \%$ do percentual masculino nessa mesma condição. Em relação às outras regiões da Província capixaba, esse número não destoa, se tomarmos como referência os dados fornecidos por Almada, segundo a qual a predominância das alforrias para as mulheres escravas se constata também no conjunto da documentação referente às outras regiões por ela pesquisadas (Vitória e Itapemirim) do total de 267 escravos libertos nas duas regiões pesquisadas, 160 (60\% do total) eram do sexo feminino e 107 (40\% do total) do sexo masculino.

Tabela 10: Sexo e idade dos escravos nas cartas de alforria em São Mateus (1863-1888).

\begin{tabular}{|c|c|c|c|c|c|c|c|c|c|c|c|}
\hline \multirow{2}{*}{$\begin{array}{l}\text { Sexo do } \\
\text { escravo }\end{array}$} & \multicolumn{10}{|c|}{ Idade do escravo } & \multirow[t]{2}{*}{ Total } \\
\hline & $\begin{array}{l}\text { Até } \\
\text { ano }\end{array}$ & $12-10$ & $11-15$ & $16-20$ & $21-30$ & & $1-4041-50$ & $51-60$ & $\begin{array}{c}\text { Acima de } \\
60\end{array}$ & $\begin{array}{r}\text { Nada } \\
\text { Consta }\end{array}$ & \\
\hline Mulheres & 3 & 2 & 4 & 5 & 7 & 6 & 9 & 4 & 3 & 71 & 114 \\
\hline Homens & 2 & 3 & - & - & 8 & 8 & 4 & 4 & 1 & 28 & 58 \\
\hline Total & 5 & 5 & 4 & 5 & 15 & 14 & 13 & 8 & 4 & 99 & 172 \\
\hline
\end{tabular}

Fonte: Cartório de 1ํ. Ofício de São Mateus.

Tais tendências, favoráveis a uma maior conquista da liberdade pelas mulheres escravas, são explicadas, via de regra, no contexto da escravidão no Brasil, por alguns fatores de ordem mais geral, tais como: menor capacidade produtiva, menor valor no 
mercado de trabalho, maior proximidade com os senhores nos serviços da casa-grande, dentre outros.

Contudo, ressalta Almada, não se pode ignorar a existência de determinadas conjunturas verificadas no país, como é o caso do período que medeia 1850 (abolição do tráfico) e 1871 (Lei do Ventre Livre), quando coube exclusivamente à mulher escrava a reprodução do sistema escravista. Ou seja, neste período, pela legislação brasileira, filhos de escravas nasciam também escravos, mesmo se o pai fosse um homem livre. A constatação desta situação, segundo Almada, fica mais evidente nas regiões economicamente mais dinâmicas, conforme verificou em Itapemirim, onde o número de alforrias entre homens $(51,2 \%)$ e mulheres escravas $(48,8 \%)$, apresentou-se proporcionalmente mais equilibrado que em outros locais do Espírito Santo - como no caso da região de Vitória, onde $67,1 \%$ das alforrias foram para as mulheres ${ }^{238}$.

\begin{tabular}{lrc}
$\begin{array}{l}\text { Tabela 11: Percentual da idade dos escravos } \\
\text { nas cartas de alforria }\end{array}$ \\
\multicolumn{3}{c}{$(1863-1888)}$. \\
\hline $\begin{array}{l}\text { Idade dos } \\
\text { escravos }\end{array}$ & Frequência & Percentual \\
\hline Até 1 ano & 5 & 2,9 \\
$2-10$ & 5 & 2,9 \\
$11-15$ & 4 & 2,3 \\
$16-20$ & 5 & 2,9 \\
$21-30$ & 15 & 8,7 \\
$31-40$ & 14 & 8,1 \\
$41-50$ & 13 & 7,6 \\
$51-60$ & 8 & 4,7 \\
Acima de 60 & 4 & 2,3 \\
Nada Consta & 99 & 57,6 \\
Total & 172 & 100,0 \\
\hline
\end{tabular}

Fonte: Cartório de 1o. Ofício de São Mateus.

Observando as Tabelas 10 e 11 deparamos com o elevado número de cartas de alforria que não trazem a idade do escravo (99 cartas ou 57,6\%). Nas 73 restantes, que constam a idade, as faixas etárias entre 21 e 30 anos predominam $(8,7 \%)$, secundadas pela de 31 a $40(8,1 \%)$. Para as mulheres, a faixa etária de 41 a 50 anos predomina, enquanto que para os homens é a de 21-30 e 31-40 anos.

Se considerarmos criança o escravo de até 15 anos, ou mesmo de 10 anos, observamos o significativo número de crianças alforriadas (14 e 10 crianças respectivamente). Ainda pela Tabela 10, tanto mulheres quanto homens acima de 60

238 ALMADA, Vilma Paraíso Ferreira de. Escravismo e Transição: o Espírito Santo (1850-1888). R.J: Edições Graal, 1984, p. 147. 
anos, são minoria nas cartas (2,3\%). Há o registro de apenas 1 escravo e de 3 escravas acima de 60 anos, o que demonstra uma reduzida expectativa de vida.

Confirmando ainda a potencialidade do regime escravista em São Mateus ainda nas últimas décadas da escravidão, a Tabela 10 indica a presença de uma população jovem e produtiva entre os alforriados. Considerando entre 16 e 50 anos uma faixa etária em idade ativa, somamos 47 escravos em idade apta para o trabalho, o que pode ser considerado um número elevado, visto que estamos trabalhando com um referencial de apenas 73 escravos.

Neste ponto há uma concordância com os estudos de Gutiérrez para o Paraná das primeiras décadas do Oitocentos, o qual ressalta a maior participação dos escravos em idade produtiva nos domicílios da região. ${ }^{239}$ Gutiérrez usando as Listas Nominativas de habitantes de algumas localidades do Paraná, também localizou um elevado percentual de crianças cativas, cujo índice representativo confirma a hipótese de ter sido normal um crescimento vegetativo positivo da população escrava local no decorrer do século XIX.

\subsubsection{Idade e preço dos cativos nas alforrias.}

Acerca da variação dos preços pagos pelas cartas de alforria no decorrer da segunda metade do século XIX, certos fatores incidiam sobre essa variação para mais ou para menos, em determinadas situações, tais como:

1. Observa-se um movimento conjuntural de alta dos preços dos cativos no país após a lei de proibição do tráfico em 1850. Essa elevação do preço dos escravos apresentou-se contínua nas décadas subseqüentes, principalmente em função da expansão da lavoura cafeeira e a conjuntura de escassez da mão-de-obra em determinadas regiões brasileiras no período. Para o caso de São Mateus, observamos que o valor dos escravos nas cartas de liberdade apresenta uma média crescente no decorrer do período enfocado;

2. Além disto, outros fatores influenciavam na variação do preço dos cativos, como é o caso da situação dos escravos em relação à idade e das condições físicas em geral (homem adulto, mulher adulta, crianças ou idosos). Dependendo do tipo de

\footnotetext{
${ }^{239}$ GUTIÉRREZ, Horacio. Demografia Escrava numa Economia Não-Exportadora: Paraná, 1800-1830. Estudos Econômicos, São Paulo, 17 (2): 297-314, maio/ago,1987.
} 
especialização profissional do cativo, seu preço também aumentava. Por outro lado, a situação dos proprietários de escravos também poderia influir na determinação das formas de alforrias e dos preços dos cativos, conforme fosse a conjuntura econômica em que o mesmo se encontrava no momento em que o escravo solicitava a compra de sua carta de liberdade.

No caso de São Mateus, a variação dos preços dos escravos conforme a idade pode ser avaliada no conjunto das alforrias onerosas/pagas (aquelas que são pagas a vista, pelo escravo ou por um terceiro) com uma amostragem muito reduzida, (v. Tabela 12) - apenas para as décadas de 1870 e 1880, pois para a década de 1860 só existe um documento. Somente 31 registros (17,5\% do total consultado) das 67 alforrias dessa forma de concessão, trazem a idade dos cativos que pagaram por suas cartas de liberdade. Sendo assim, vamos nos restringir a uma breve apresentação e análise da relação dos 31 escravos que tiveram suas idades registradas nas cartas de alforria.

Tabela 12: Idade e preço dos cativos nas cartas de alforria em São Mateus: 1867/1888.

\begin{tabular}{|c|c|c|}
\hline Data dos registros & Nome e idade dos alforriados & Preços das alforrias (réis) \\
\hline 1867 & Maria/ filha de Vitória (crianca?) & $400 \$ 000$ \\
\hline 1871 & Maria / 16 anos & $1: 300 \$ 000$ \\
\hline 1874 & Lésio / 50 anos & $400 \$ 000$ \\
\hline 1874 & Thomas/50 anos & $300 \$ 000$ \\
\hline 1875 & Luís / 50 anos & $400 \$ 000$ \\
\hline 1875 & Rufina / 56 anos & $200 \$ 000$ \\
\hline 1876 & Jesuína/41 a 50 anos & $600 \$ 000$ \\
\hline 1876 & Theodorico/31 a40 anos & $1: 200 \$ 000$ \\
\hline 1877 & Damião / 67 anos & $500 \$ 000$ \\
\hline 1877 & Lúcia/41 a 50 anos & $1: 000 \$ 000$ \\
\hline 1877 & Raymundo/41 a 50 anos & $500 \$ 000$ \\
\hline 1877 & Arnalda/41 a 50 anos & $600 \$ 000$ \\
\hline 1877 & Joana/21 a 30 anos & $400 \$ 000$ \\
\hline 1882 & João / de Nação/ 30 anos & $500 \$ 000$ \\
\hline 1885 & Geraldino/21 a 30 anos & $600 \$ 000$ \\
\hline 1887 & Januária/ 40 anos & $300 \$ 000$ \\
\hline 1887 & Rita/16 a 20 anos & $661 \$ 000$ \\
\hline 1888 & Marcolino/ 25 anos & $854 \$ 000$ \\
\hline 1888 & Antônio/ 27 anos & $854 \$ 000$ \\
\hline 1888 & Aprígio/31 a 40 anos & $768 \$ 000$ \\
\hline 1888 & Cândido/31 a 40 anos & $768 \$ 000$ \\
\hline 1888 & João/31 a 40 anos & $768 \$ 000$ \\
\hline 1888 & Athanázio/21 a 30 anos & $854 \$ 000$ \\
\hline 1888 & Antonio/21 a 30 anos & $854 \$ 000$ \\
\hline 1888 & Victorio/21 a 30 anos & $854 \$ 000$ \\
\hline 1888 & Maria/21 a 30 anos & $648 \$ 000$ \\
\hline 1888 & Francisco/41 a 50 anos & $576 \$ 000$ \\
\hline 1888 & Rogesino/21 a 30 anos & $864 \$ 000$ \\
\hline 1888 & Referina/31 a 40 anos & $576 \$ 000$ \\
\hline 1888 & Iria/21 a 30 anos & $648 \$ 000$ \\
\hline 1888 & Severina/41 a 50 anos & $400 \$ 000$ \\
\hline
\end{tabular}


Conforme podemos observar na Tabela 13, a média de preço das alforrias dos cativos homens era de aproximadamente 550\$000 rs. na década de 1870, possuindo quase todos escravos mais de 30 anos. (V. Tabela 12) É curioso o fato do escravo Damião, de 67 anos (portanto, bem idoso) ter pago $500 \$ 000$ rs. em 1877 por sua liberdade, ao passo que o escravo João, de 30 anos (jovem), pagou esta mesma quantia por sua alforria cinco anos depois (1882). Talvez nessa situação tal fato possa ser explicado pela especialização profissional do escravo. Na década de 1880 a média de preço dos cativos homens sobe para $567 \$ 000$ rs.

Tabela 13: Preços médios de cativos nas cartas de alforria em São Mateus: 1867/1888.

Data dos registros Número de alforriados $\quad$ Preços das alforrias

(em réis)

A - Preços médios dos cativos por décadas em 31 cartas de alforria.

$\begin{array}{lcc}1860-1869 & 1 \text { alforriado (Maria/filha de Vitória) } & 400 \$ 000 \\ 1870-1879 & 12 \text { alforriados (6 mulheres e } 6 \text { homens) } & 617 \$ 000 \\ 1880-1888 & 18 \text { alforriados (6 mulheres e 12 homens) } & 719 \$ 000\end{array}$

B - Preços médios de cativos homens por décadas em 31 cartas de alforria.

1860-1869

$1870-1879$

$1880-1888$

6 alforriados

$550 \$ 000$

12 alforriados

$567 \$ 500$

C - Preços médios de cativos mulheres por décadas em 31 cartas de alforria.

$\begin{array}{lll}1860-1869 & 1 \text { alforriado (Maria/ filha de Vitória) } & 400 \$ 000 \\ 1870-1879 & 6 \text { alforriados } & 683 \$ 000 \\ 1880-1888 & 6 \text { alforriados } & 538 \$ 000\end{array}$

Fonte: Cartório de 1ํ. Ofício de São Mateus.

Em relação às mulheres alforriadas o preço médio na década de 1870 é mais alto em comparação com os homens, apresentando o valor de $683 \$ 000$ rs., ao passo que na década seguinte (1880), cai para 538\$000 rs. 
Acompanhando a tendência do país, os preços médios dos cativos sobem nas três décadas pesquisadas (apesar de não termos amostragens para a década de 1860). A média de 1870, 617\$000 rs. sobe para $719 \$ 000$ rs. em 1880.

Ao estudar a proporção entre cartas de alforria pagas e gratuitas na Bahia (16841745), Schwartz demonstrou que, à medida que o valor do escravo crescia, tornava-se cada vez maior a quantidade de senhores que exigiam pagamento em dinheiro para a concessão da liberdade. No caso do Rio de Janeiro (entre o final do século XVIII e meados do século XIX), Florentino indica que a maior parte dos escravos obteve seu documento de liberdade através do pagamento em dinheiro. ${ }^{240}$

Tabela 14: Forma de concessão e idade do escravo nas cartas de alforria (1863-1888).

\begin{tabular}{|c|c|c|c|c|c|c|c|c|c|c|c|}
\hline \multirow[t]{2}{*}{ Forma de concessão } & \multicolumn{9}{|c|}{ Idade do escravo } & \multirow[b]{2}{*}{$\begin{array}{l}\text { Nada } \\
\text { Consta }\end{array}$} & \multirow[b]{2}{*}{ Total } \\
\hline & $\begin{array}{l}\text { Até } 1 \\
\text { ano }\end{array}$ & $2-10$ & $11-15$ & $16-20$ & $21-30$ & $31-40$ & $41-50$ & $51-60$ & $\begin{array}{c}\text { Acima } \\
\text { de } 60\end{array}$ & & \\
\hline Paga/onerosa & - & - & - & 2 & 9 & 7 & 7 & 3 & 2 & 37 & 67 \\
\hline Condicional & - & - & - & 1 & 4 & 1 & 1 & 1 & - & 11 & 19 \\
\hline $\begin{array}{l}\text { Testamento/ } \\
\text { inventário }\end{array}$ & - & - & - & - & 1 & - & 1 & - & 1 & 3 & 6 \\
\hline Incondicional & 1 & 2 & 2 & - & - & - & - & 2 & - & 14 & 21 \\
\hline Via Judicial/protesto & 1 & 1 & - & - & - & 3 & 1 & 1 & - & 12 & 19 \\
\hline Coartação/Met. alf. & - & & - & - & 1 & & - & 1 & - & 7 & 9 \\
\hline Nada Consta & 3 & 2 & 2 & 2 & - & 3 & 3 & - & 1 & 15 & 31 \\
\hline Total & 5 & 5 & 4 & 5 & 15 & 14 & 13 & 8 & 4 & 99 & 172 \\
\hline
\end{tabular}

Fonte: Cartório de 1‥ Ofício de São Mateus.

Como já nos referimos anteriormente, a forma de concessão paga/onerosa foi a predominante nas alforrias de São Mateus (são 67 cartas, representando 39,0\% do total das manumissões), confirmando assim uma tendência geral da época. Pela Tabela 13 podemos observar que nesta forma de concessão, a faixa etária de 21-30 anos predomina (com um total de 9 escravos), secundada pelas faixas de 31-40 e 41-50 anos (7 escravos cada uma).

Do conjunto das 67 cartas onerosas/pagas, em 37 não consta a idade do cativo. Entre as 30 restantes, apenas duas se refere à mais de 60 anos, duas à faixa etária de 1620 anos e três a 51-60 anos. Nas 23 restantes as faixas que variam de 21-50 anos predominam, confirmando novamente uma tendência geral da época.

240 SCHWARTZ, Stuart B. Escravos, roceiros e rebeldes. Bauru: EDUSC, 2001 e FLORENTINO, Manolo. Alforrias e etnicidade no Rio de Janeiro Oitocentista: notas de pesquisa. TOPOI. Revista de História. R.J., UFRJ/ 7 Letras, n.5, 2002. 
4.4.3. Origem/procedência e cores dos escravos nas cartas de alforria.

Desde o período colonial foi sendo criado no Brasil um sistema de classificação de cores, o qual poderia variar de acordo com o local e a época, influenciado pela forma portuguesa de identificação da origem étnica e da cor do escravo.

No Oitocentos, a vila de São Mateus, produziu os forros de variadas cores, sendo estes, pretos, crioulos, mulatos, pardos e cabras. (v. Tabela 15)

Tabela 15: Cores dos escravos nas cartas de alforria (1863-1888).

\begin{tabular}{lcc}
\hline Cor & Frequência & Percentual \\
\hline Pretos & 28 & 16,3 \\
Pardos & 21 & 12,2 \\
Crioulos & 19 & 11,0 \\
Cabras & 14 & 8,1 \\
Mulatos & 7 & 4,1 \\
Nada Consta & 83 & 48,3 \\
Total & 172 & 100,0 \\
\hline
\end{tabular}

Fonte: Fonte: Cartório de 1ํ. Ofício de São Mateus.

Em grande parte das alforrias (83 cartas ou 48,3\% do total) não foi constatada a cor do escravo, o que reduziu enormemente os dados para a quantificação dessa importante variável nos documentos pesquisados, o que nos leva a deduzir que boa parte destas alforrias derivaram de espólios, testamentos, ações judiciais etc, onde já estava registrado a cor e outras características do escravo, assim como nas cartas de liberdade de escravos já 'matriculados' (inscritos no Livro de Matrículas - instituído em 1872 pelo governo central - na Collectoria Geral do município).

Os pretos predominaram na obtenção das alforrias (28 alforriados), alcançando um percentual de 16,3\% do total. Em segundo lugar vem os pardos (21 alforriados), com um percentual de 12,2\%, seguidos pelos crioulos (19 alforriados - 11,0\%), e pelos de cor cabra (14 alforriados -8,1\%). Os mulatos são a minoria, com apenas 7 alforrias (4,1\% do total). Devemos frisar que o termo crioulo extraído destes documentos se refere à cor do escravo e não ao escravo nascido no Brasil, como nos referimos no capítulo anterior referente às compras e vendas de cativos. ${ }^{241}$

\footnotetext{
${ }^{241} \mathrm{O}$ termo crioulo neste contexto especifica uma cor e não a origem dos escravos (aqueles nascidos no Brasil em contraposição aos termos africano, boçal e outros que distinguem os nascidos na África).
} 
Embora os pardos figurem em segundo lugar entre os alforriados de São Mateus, estudos recentes demonstram que na segunda metade do século XIX, na maior parte das regiões brasileiras, os alforriados eram, em sua maioria, classificados como 'pardos' devido à miscigenação e ao fim do tráfico atlântico. ${ }^{242}$

Segundo Herbert Klein "os preconceitos raciais da sociedade branca indicavam que a alforria favoreceria os de origem racial mestiça em detrimento de seus companheiros não-mestiços", citando como exemplo a cidade de Sabará/MG, em que os pardos representavam $84 \%$ das pessoas de cor livre. ${ }^{243}$

Não obstante ressaltaremos uma afirmação de outro pesquisador, ${ }^{244}$ ao dizer que “a cor parece não ter tido significação nas alforrias". Sabemos que é reconhecido que as cores pardas e cabras são as mais comuns na obtenção de alforrias, embora esta última para as alforrias de São Mateus contabiliza apenas 14 escravos alforriados.

A denominação cabra algumas vezes pode ser até incorporada aos nomes dos escravos, pois cabra além da cor, era utilizado para caracterizar os escravos com feições de pessoas brancas, inclusive crianças, em cujo nome pode vir acompanhado o termo cabrinha. Encontramos alguns casos destes, de crianças, entre os escravos de São Mateus.

Quanto ao fato dos pretos representarem a maioria alforriada em São Mateus, não quer dizer que alguns não sejam africanos. Acerca disto, podemos tomar como referência a pesquisa de Mary Karasch que examinou, em seu estudo sobre alforrias no Rio de Janeiro, embora numa conjuntura distinta à deste estudo, a seguinte configuração: "os libertos brasileiros levavam vantagem sobre os africanos. Os 732 brasileiros $(56 \%)$ superavam os 504 africanos $(38 \%)$ da amostra. Os racialmente misturados estavam em minoria porque parece que a população escrava carioca era esmagadoramente negra." 245

\footnotetext{
${ }^{242}$ Cf. PIRES, M. de Fátima Novais. Cartas de alforria: para não ter o desgosto de ficar em cativeiro. Revista Brasileira de História. vol.26, n.52. São Paulo, Dec. 2006. http://dx.doi.org/10.1590/S010201882006000200007.

${ }^{243}$ KLEIN, Herbert S.; PAIVA, Clotilde Andrade. Libertos em uma economia escravista: Minas Gerais em 1831. Estudos Econômicos, São Paulo, USP/IPE, v.27, n.2, 199, p.177-335.

${ }^{244}$ KNOX, Miridan B. Escravos do sertão - Demografia, trabalho e relações sociais: Piauí (1826-1888). 1993. Tese (Doutorado em História Social) FFLCH/ USP,1993, p.1997.

${ }^{245}$ KARASCH, Mary. A vida dos escravos no Rio de Janeiro (1808-1850). São Paulo: Companhia das Letras, 2000, p. 459.
} 
Essa disposição da população negra, mais visível na Corte nas duas últimas décadas da escravidão, traça um quadro aparentemente semelhante daquele que podemos observar em São Mateus, ou seja, da predominância de uma população negra.

Tabela 16: Origem / procedência dos escravos nas cartas de alforria (1863-1888).

\begin{tabular}{lcc}
\hline $\begin{array}{l}\text { Etnia do } \\
\text { escravo }\end{array}$ & Frequência & Percentual \\
\hline São Mateus & 47 & 27,3 \\
Africanos/de & 20 & 11,6 \\
nação & & \\
Outras regiões & 7 & 4,1 \\
Nada Consta & 98 & 57,0 \\
Total & 172 & 100,0 \\
\hline
\end{tabular}

Fonte: Cartório de 1‥ Ofício de São Mateus.

De acordo com a tabela 16, os escravos nativos (da região de São Mateus) aparecem em primeiro lugar nas cartas de alforria (27,3\%), enquanto os de outras regiões somam-se 7, constituindo minoria, entre estes procedentes do Rio de Janeiro, de Minas e da Bahia e de outras regiões da província.

Os africanos/de nação aparecem em terceiro lugar, contabilizando 20 escravos $(11,6 \% \text { do total })^{246}$. A partir de 1850 , a dificuldade de identificar com maior precisão a origem de todos os povos africanos que desembarcaram no Brasil, e no Espírito Santo especificamente, é agravada, já que, com a proibição do tráfico negreiro, os que eram desembarcados eram mandados para as fazendas e registrados às vezes como nascidos ali. Tratava-se de e um artifício usado para burlar a legislação que dava direito à liberdade aos africanos trazidos como escravos pelos traficantes. ${ }^{247}$

\footnotetext{
${ }^{246}$ Os termos africano e de nação estão agrupados nesta Tabela devido ao fato de que grande parte dos escravos 'de nação' poderiam ser 'africanos' ou vice-versa na segunda metade do século XIX, mas nem todos. Como não estamos nos referindo a etnia e sim à procedência não nos pareceu erro agrupá-los num único bloco. Entre os 'de nação' temos o registro de mais angolanos e de poucos de outras nações da África centro-ocidental. Segundo Marina de Mello e Souza, "nação do século XV ao XIX designava um grupo com características culturais diferentes daqueles que a ele se referiam. Judeus e ciganos, tupinambás e carijós, minas e angolas eram grupos 'de nação' conforme o linguajar de todo esse período". v. SOUZA, Marina de M. e. África e Brasil Africano. São Paulo: Ed. Ática, 2009, p. 62.

247 "A despeito da Lei Eusébio de Queirós de 1850 proibindo as importações de escravos, a vizinhança com as Províncias de Minas Gerais e Rio de Janeiro tornou o litoral do Espírito Santo uma das regiões mais visitadas pelos 'negreiros'. A zona sul da Província foi a mais visada pelos contrabandistas, chegando a haver desembarques nas proximidades de Vitória [...] Logo, mesmo depois de 1850, quando o preço do escravo tornou-se mais elevado, a população escrava continuou aumentando na Província, principalmente por causa da expansão cafeeira" (Cf. JESUS, Aloiza Delurde Reali de. Comarca de Vitória: escravo de ganho e aluguel. (1850-1871). Monografia. Depto de História/UFES, 2006).
} 
Novamente a grande maioria das alforrias, 98 cartas (57,0\%) nada constaram acerca da procedência dos escravos, reduzindo enormemente a quantificação dos dados da pesquisa.

\subsubsection{Ocupação do escravo.}

Mais vago do que no caso das variáveis cor e procedência do escravo, a documentação pesquisada (172 alforrias) não se refere à forma de ocupação do alforriado em 147 documentos (85,5\% do total). Apenas em 25 documentos este dado é fornecido. (v. Tabela 17)

Não se observa nas fontes pesquisadas, discriminação de 'cor' para ocupação nessa ou naquela função. Os alforriados, classificados como 'pretos', 'crioulos', 'mulatos', 'pardos', e outros são identificados em suas formas de ocupação como: apropriados para serviços da lavoura (14 alforriados); cozinheiras (6 alforriadas); serviços domésticos (3); serviços domésticos e da lavoura (1) e com especialização em algum ofício (1). Sabemos que na realidade trabalhavam como ferreiros e lavradores (na lavoura cafeeira e na produção da farinha de mandioca), como cozinheiras e costureiras, cuidavam de animais, eram os carregadores nos armazéns e nas embarcações do porto, dentre inúmeras outras ocupações, independentes de grupos étnicos ou de 'cor'. Do ponto de vista de uma formação mais especializada para o trabalho tanto nas fazendas como na cidade, é mais provável pensá-la associada à habilidade e ao 'comportamento' do escravo.

Tabela 17: Percentual das formas de ocupação do escravo nas cartas de alforria (1863-1888).

\begin{tabular}{lcc}
\hline $\begin{array}{l}\text { Formas de ocupação } \\
\text { do escravo }\end{array}$ & Frequência & Percentual \\
\hline Serviços da Lavoura & 14 & 8,1 \\
Cozinheira & 6 & 3,5 \\
Serviços Domésticos & 3 & 1,7 \\
$\begin{array}{l}\text { Serviços Domésticos } \\
\text { e Lavoura }\end{array}$ & 1 & \\
Especialização & & 0,6 \\
em algum ofício & 1 & 0,6 \\
Nada Consta & 147 & 85,5 \\
Total & 172 & 100,0 \\
\hline
\end{tabular}

Fonte: Cartório de 1ํo. Ofício de São Mateus. 


\subsubsection{Estado conjugal do escravo.}

Podemos observar pela Tabela 18 que não há nenhuma equivalência numérica entre alforriados casados e solteiros. O elevadíssimo número de escravos solteiros (40) e o baixo número de casados (8), para uma amostragem de 48 elementos - já que 124 documentos não constaram o estado conjugal do escravo - já fornece alguns indícios, de antemão, acerca das relações matrimoniais dos escravos de São Mateus. Porém, devemos nos atentar para o fato de que a frequência ínfima de casamentos oficiais não significa que não houve ausência de relações familiares entre os cativos da região. Não há referências a alforriados viúvos (as).

Tabela 18: Estado conjugal do escravo nas cartas

\begin{tabular}{|c|c|c|}
\hline Estado conjugal & Frequência & Percentual \\
\hline Solteiro & 40 & 23,3 \\
\hline Casado & 8 & 4,7 \\
\hline Nada Consta & 124 & 72,1 \\
\hline Total & 172 & 100,0 \\
\hline
\end{tabular}

Fonte: Cartório de 1ํ. Ofício de São Mateus.

\subsubsection{Nome do escravo.}

Acerca dos nomes dos escravos (as), podemos inferir as seguintes questões a partir das tabelas geradas com base em dados extraídos das cartas de alforrias (v. Tabela em ANEXO 1 - Tabela 1)

\subsection{Nomes das escravas:}

- em primeiro lugar aparece Maria, com o percentual de 4,7\% do total, ou seja, com oito ocorrências; em segundo lugar Francisca (2,3\%) e em terceiro, Severina $(1,7 \%)$;

- apresentam duas incidências (1,2\% do total) os seguintes nomes de escravas: Rita, Constança, Serafina, Rufina, Thereza, Carolina, Benedicta, Januária, Magdalena, Rosinda, Florência, Rosa, Genoveva, Virgínia e Marcolina. 
- os demais nomes de escravas apresentam somente uma ocorrência $(0,6 \%)$, a exemplo de Anna e outros. Mesmo considerando a situação contraditória que os significados destes nomes representam no contexto da escravidão: Fé, Filizarda, Piedade, Felícia, Innocência, Cândida, Felismina, Angélica, Felicidade e outros, sendo que em certos casos, muitos dos nomes dados às escravas e escravos, correspondiam aos mesmos nomes dos seus senhores, proprietários (as) etc.

\subsection{Nome dos escravos:}

- em primeiro lugar aparece Francisco, com quatro incidências (2,3\% do total) e em segundo lugar João, com três incidências $(1,7 \%)$;

- nome de escravos com duas incidências (1,2\% do total): Cândido, Theodorico, Honorato, Sebastião, Antonio e Ricardo;

- os demais nomes de escravos aparecem com apenas uma incidência $(0,6 \%)$, a exemplo de José (que é um nome muito comum) dentre os quais também observamos a mesma situação contraditória apontada no caso das mulheres escravas: Felicíssimo, Victorio e outros;

- No conjunto masculino, aparece somente um escravo com dois nomes: Manuel Jorge.

\subsection{Aspectos comparativos.}

O número total de cartas de alforria de São Mateus (172 registros) apresenta-se elevado em relação ao total das outras duas maiores regiões produtivas da Província do Espírito Santo - conforme dados da pesquisa de Almada, que constatou 267 cartas de liberdade para Vitória e Itapemirim, praticamente no mesmo período 1867/1888 (destas, 215 registradas em Cartórios do $2^{\circ}$. Ofício de Notas de Vitória e Itapemirim e as 52 restantes em Inventários post-mortem ${ }^{248}$.

\footnotetext{
${ }^{248}$ ALMADA, Vilma Ferreira de. Escravismo e Transição: o Espírito Santo (1850-1888). R.J. : Ed. Graal, 1984, p, 146, 147.
} 
No caso de Itapemirim, num total de 121 alforrias pesquisadas, 50 registros $(41,4 \%)$ apresentam a concessão da liberdade condicionada à prestação de serviços. Na região de Vitória, num total de 146 alforrias pesquisadas, 67 registros $(45,9 \%)$ referemse à concessão de liberdade através da compra.

Nas regiões pesquisadas por Almada (Itapemirim e Vitória), esta variação das formas de aquisição da liberdade pelos escravos e as diferentes formas de pagamento das mesmas, resultavam segundo a autora, das necessidades diversas existentes em ambas as regiões, principalmente nas duas últimas décadas da vigência do regime escravista, onde pode-se deduzir que em Vitória a venda de alforrias significava a obtenção de capitais para os senhores endividados, ao passo que, em Itapemirim, a predominância da venda de alforria sob a condição da prestação de serviços significava a dependência dos senhores ao sistema escravista, num contexto de expansão da lavoura cafeeira.

Ao contrário de Itapemirim, em São Mateus o reduzido número de cartas condicionais 'condicionadas' à prestação de serviços (12 cartas - v. Tabela 5, somadas a apenas mais 3 da categoria metade alforriada/coartações que envolve prestação de serviços), nos leva a inferir que a dependência dos senhores em relação à mão-de-obra escrava é muito menos acentuada que na região sul da província, já que a região também dispõe de uma parcela de trabalhadores livres pobres, e não está em área de plantation.

Também o reduzido número de incondicionais/sem ônus (21 cartas) em São Mateus, paralelamente à grande movimentação de compra e venda de escravos entre os anos de 1863 e 1887, como vimos no capítulo anterior, nos leva a pensar que a grande importância do escravo se deve mais enquanto objeto de mercantilização e capitalização mercantil, e não como mão-de-obra.

O caráter extremamente mercantil que presidiu as relações escravistas em São Mateus - cuja evidência imediata é o predomínio numérico das fontes cartorárias relativas às escrituras de compra e venda de escravos e de outros tipos de transações comerciais envolvendo preço do escravo - pode ser entendido como a característica primordial da sustentação do escravismo na sociedade mateense na segunda metade do Oitocentos. 
CONSIDERAÇÕES FINAIS 
As mudanças ocorridas na historiografia econômica brasileira levaram a uma valorização dos estudos sobre as especificidades das economias e das sociedades existentes nas diversas regiões brasileiras. Inserida nesse novo contexto, a escravidão passou a ser estudada levando-se em conta as especificidades de cada região e com o respaldo de densas pesquisas documentais. Nesse sentido a escravidão tanto rural quanto a urbana, passou a ser tema de interesse de vários pesquisadores. Esta pesquisa teve por intenção se enquadrar nesta perspectiva, por se tratar de uma região que envolve dois núcleos urbanos (a cidade de São Mateus e a Vila da Barra - hoje cidade de Conceição da Barra), englobando também uma vasta área rural de dimensões territoriais das mais significativas (hoje equivalente à área de 14 municípios praticamente todo o extremo norte do Espírito Santo).

Buscou-se traçar, de maneira geral, alguns aspectos desta região, na segunda metade do século XIX, a partir da Lei Eusébio de Queirós, em 1850, quando é proibido o tráfico de escravos. Devemos ressaltar que, para a maior parte dos autores capixabas, nesse período há um aumento do tráfico ilegal de escravos e uma intensificação da vinda de imigrantes devido à expansão cafeeira. Foi em meados do século XIX que se delinearam as principais características que deram um novo direcionamento econômico e social para a Província do Espírito Santo.

A presença do negro na população capixaba torna-se bastante expressiva neste período e mesmo após a Abolição. Segundo a historiadora capixaba Maria Stella de Novaes, Vitória era chamada de Terra de Negros. Novaes afirma que o litoral capixaba tornou-se lugar privilegiado para entrada ilegal de escravos desde a proibição do tráfico em 1831, ressaltando também que o Barão de Itapemirim foi um dos maiores escravagistas do Sudeste e acobertador do contrabando de cativos, juntamente com outros fazendeiros que tinham na mão-de-obra escrava a totalidade de seus trabalhadores. ${ }^{249}$

A região de São Mateus não foge a regra geral em relação à entrada e fixação do negro em seu território, visto que está inserida na rota da navegação de cabotagem não

\footnotetext{
${ }^{249}$ NOVAES, Maria Stella de. A escravidão e a abolição no Espírito Santo: história e folclore. Vitória: Departamento de Imprensa Oficial, 1963, p. 83. Segundo Novaes, em 7 de abril de 1856, o Chefe de Polícia da Corte relatava as feitorias de escravos na África, e apontava, como principal porto de desembarque, no Brasil, o porto de Itapemirim. (NOVAES, 1963, p. 91).
} 
só da província, mas de também da costa brasileira. ${ }^{250}$ A sua peculiaridade reside exatamente no fato de possuir um porto fluvial de fácil acesso para a população local e regional, atrelado a outro marítimo que subsidia o tráfico costeiro, cuja navegação principalmente de embarcações maiores, não adentra o rio São Mateus, possibilitando assim o estabelecimento de relações comerciais envolvendo os vários setores locais (o agrário, o mercantil e o de serviços) que fazem a conexão entre os dois portos.

Frente a tal conjuntura sócio-econômica e demográfica, cuja inserção do negro foi fundamental para a estruturação das forças produtivas agrárias da região, pretendeuse no primeiro capítulo, destacar as peculiaridades locais com ênfase na escravidão, a partir de uma coletânea de informações históricas, sociais e econômicas significativas para o período estudado - baseadas na limitadíssima bibliografia existente.

$\mathrm{Na}$ segunda parte deste estudo, procuramos reunir informações e análises visando fornecer uma panorâmica das questões relativas à escravidão no Espírito Santo na segunda metade do século XIX, com foco privilegiado na região de São Mateus, destacando os temas mais recorrentes na documentação de caráter oficial produzida nas instâncias político-administrativas da província capixaba, principalmente nos relatórios presidenciais e na legislação provincial do período.

Ao finalizarmos as abordagens dos tópicos e temáticas integrantes deste capítulo, constatamos que no Espírito Santo a incidência de episódios e situações inerentes às formas de resistência/reação dos escravos às condições impostas pelo cativeiro foi bastante expressiva, cujas principais manifestações, conforme os registros encontrados na documentação oficial, envolveram as constantes fugas de escravos e a concomitante proliferação dos quilombos em diversas partes do território capixaba.

Neste sentido, observamos também que as autoridades provinciais encontraram sérios obstáculos para lidar com tais situações, haja vista os diversos registros de queixas e avaliações críticas acerca dos inexpressivos resultados obtidos pelas guerrilhas criadas para captura de escravos fugitivos e destruição dos quilombos na província, e cuja principal alegação do governo residia na falta de verbas e nas dificuldades para composição das referidas guerrilhas.

No transcurso do período identificamos ainda um grande número de ameaças e/ou ocorrências de revoltas e insurreições escravas, sobretudo em meados do

\footnotetext{
${ }^{250}$ Devemos ressaltar que não temos informações do envolvimento do Barão de Aimorés em contrabando de escravos (como é amplamente delatado no caso do Barão de Itapemirim). Sabemos somente do envolvimento de sua mãe, Dona Rita, com o quilombo do Negro Rugério.
} 
Oitocentos e nas etapas finais de vigência do sistema escravista no país, cujas tendências também foram apontadas em estudos referentes a outras províncias brasileiras, principalmente nas áreas cafeeiras, onde tais situações são geralmente associadas às conjunturas advindas das principais leis decretadas pelo governo imperial com vistas à abolição gradual da escravidão no Brasil.

Em suma, mesmo levando-se em conta que certas particularidades da escravidão regional influenciaram na configuração e nas características do sistema escravista no Espírito Santo, este apresenta similaridades e sintonias com os rumos e diretrizes que marcaram a vigência da escravidão no contexto brasileiro.

No caso específico da escravidão em São Mateus, notamos que nesta região foram frequentes as ocorrências de fatos e situações inerentes aos temas enfocados neste segundo capítulo, demonstrando que, mesmo possuindo um contingente escravo de menores proporções que o centro e o sul da província, São Mateus se notabiliza enquanto foco de diversos episódios envolvendo a resistência escrava às adversas condições do cativeiro.

Num terceiro momento da pesquisa, agora utilizando-se de um outro conjunto de outras fontes primárias - as cartoriais - a partir de uma análise comparativa com outras pesquisas mais amplas sobre alforrias e compra e venda de escravos no Brasil, pode-se ter uma idéia mais precisa acerca da conquista da liberdade por parte dos escravos, para o caso das alforrias, paradoxalmente à importância comercial que estes possuíam, o que pode ser atestado nas escrituras de compra e venda, onde os cativos são configurados não só enquanto mão-de-obra para a sustentação das lavouras, mas principalmente como um bem mercantil de segura negociação.

Constatamos a predominância das alforrias onerosas/pagas $(39,0 \%)$ sobre as condicionais $(11,0 \%)$ e sobre as incondicionais/sem ônus $(12,2 \%)$ e que o percentual das onerosas é muito elevado em relação a todas as outras. Consideramos que é pequeno o número de cartas incondicionais/sem ônus (apenas 21) em relação tanto ao elevado número de escravos existentes em São Mateus nas décadas de 1870 e 1880, assim como também em relação ao conjunto das alforrias registradas no período estudado. Notamos a predileção em alforriar o cativo do sexo feminino, o que pode ser explicado pela maior possibilidade que as mulheres escravas possuíam em estabelecer laços afetivos com seus senhores, seja pelas profissões exercidas, seja pelas relações 
sexuais, o que as tornavam mais próximas destes e mais presentes nos momentos de dificuldade.

Consideramos que a quantidade das alforrias concedidas (172 cartas) foram poucas se compararmos o elevado número da população cativa da região, $2.813 \mathrm{em}$ 1872, por exemplo, inserida em uma população de 22.659 escravos para toda a província. Para a região sul da mesma, Almada também constatou um baixo número de cartas de alforrias.

Em relação à pesquisa dos preços dos escravos, foi possível verificar que o preço médio do escravo em São Mateus era mais baixo que nas regiões pesquisadas por Almada (Vitória e Itapemirim), e que, como qualquer mercadoria seu valor regulava-se pela lei da oferta e da procura, vindo a sofrer grandes modificações ao longo da segunda metade do século XIX, já que a crescente necessidade de mão-de-obra nas lavouras cafeeiras da província vai coincidir com o fim do tráfico de africanos.

Os resultados para São Mateus não estão dentro da perspectiva de uma região de grande lavoura, onde o escravo é mão-de-obra primordial na produção agrícola, sendo que o número de alforrias (mesmo considerado mais alto em relação a Vitória e Itapemirim no mesmo período) não representa qualquer ameaça ao sistema e ao domínio senhorial. Em relação à região sul, região monocultora onde se concentra a maior parte da produção cafeeira da província, e, portanto, com grande demanda de mão-de-obra escrava, poderia se justificar o baixo índice de alforrias, mas para a região norte, estruturada em um modelo econômico que não corresponde ao de plantation, impõe-se outras reflexões para os resultados alcançados.

Assim, este estudo traz uma contribuição para as áreas escravistas mais voltadas para a subsistência e, em particular, para o melhor conhecimento da história demográfica e agrária do Espírito Santo. 


\section{FONTES E BIBLIOGRAFIA}

\section{Fontes impressas:}

- Legislação Provincial do Espírito Santo. Ementário das Leis Provinciais (1835/1888).

APEES (www.ape.es.gov.br).

- Posturas Municipais de São Mateus e de Villa da Barra de São Mateus.

APEES (www.ape.es.gov.br).

- Relatórios dos Presidentes de Província (décadas de 1840 a 1880).

APEES (www.ape.es.gov.br).

Entre os relatórios presidenciais, foram utilizados os seguintes:

- Relatório do Presidente da Província do Espírito Santo Luís Pedreira do Coutto Ferraz, de 01/03/1848.

- Relatório do Presidente da Província do Espírito Santo Antonio Pereira Pinto, de 30/11/1848.

- Relatório do Vice-Presidente da Província do Espírito Santo José Francisco Andrade Almeida Monjardim, de 01/08/1848.

- Relatório do Presidente da Província do Espírito Santo Antonio Joaquim de Siqueira, de $11 / 03 / 1849$.

- Relatório do Presidente da Província do Espírito Santo Fellipe José Pereira Leal, de 25/07/1850.

- Relatório do Presidente da Província do Espírito Santo José Bonifácio Nascentes D’Azambuja, de 24/05/1852.

- Relatório do Presidente da Província do Espírito Santo Evaristo Ladislau e Silva, de 23/05/ 1853

- Relatório do Presidente da Província do Espírito Santo Sebastião Machado Nunes, de 25/05/1854.

- Relatório do Presidente da Província do Espírito Santo Sebastião Machado Nunes, de 25/05/1855.

- Relatório do Vice-Presidente da Província do Espírito Santo Barão de Itapemirim, de 08/03/1856. 
- Relatório do Presidente da Província do Espírito Santo José Maurício Fernandes Pereira de Barros, de 13/02/1857.

- Relatório do Vice-Presidente da Província do Espírito Santo Barão de Itapemirim, de 25/05/1857.

- Relatório do Presidente da Província do Espírito Santo Pedro Leão Velloso, de 25/01/1859.

- Relatório do Presidente da Província do Espírito Santo José Fernandes da Costa Pereira Júnior, de 23/05/1861.

- Relatório do Presidente da Província do Espírito Santo José Fernandes da Costa Pereira Júnior, de 25/05/1862.

- Relatório do Presidente da Província do Espírito Santo André Augusto de Pádua Fleury, de 20/10/1863.

- Relatório do Vice-Presidente da Província do Espírito Santo Eduardo Pindahyba de Mattos, de 21/02/1864.

- Relatório do Vice-Presidente da Província do Espírito Santo Eduardo Pindahyba, de Mattos, 03/10/1864.

- Relatório do Vice-Presidente da Província do Espírito Santo Eduardo Pindahyba, de Mattos, de 08/01/1865.

- Relatório do Presidente da Província do Espírito Santo José Joaquim do Carmo, de 26/05/1865.

- Relatório do Presidente da Província do Espírito Santo Alexandre Rodrigues da Silva Chaves, de 25/05/1866.

- Relatório do Vice-Presidente da Província do Espírito Santo Carlos de Cerqueira Pinto, de 23/05/1867.

- Relatório do Presidente da Província do Espírito Santo Francisco Leite Bittencourt Sampaio, de Abril/1868.

- Relatório do Presidente da Província do Espírito Santo Francisco Ferreira Correa, de 09/10/1871.

- Relatório do Presidente da Província do Espírito Santo Antonio Gabriel de Paula Fonseca, de 02/10/1872.

- Relatório do Vice-Presidente da Província do Espírito Santo Manoel Ribeiro Coitinho Mascarenhas, de 06/11/1873. 
- Relatório do Presidente da Província do Espírito Santo Antonio Joaquim de Miranda Nogueira da Gama, de 11/07/1877.

- Relatório do Presidente da Província do Espírito Santo Alpheu Adelpho Monjardim d'Andrade e Almeida, de 06/03/1879.

- Relatório do Presidente da Província do Espírito Santo Marcelino de Assis Tostes, de 08/03/1881.

- Relatório do Presidente da Província do Espírito Santo Martim Francisco Ribeiro de Andrada Júnior, de 03/03/1883.

- Relatório do Presidente da Província do Espírito Santo José Camillo Ferreira Rebello, de $17 / 09 / 1884$.

- Relatório do Vice-Presidente da Província do Espírito Santo Manoel Ribeiro Coitinho Mascarenhas, de 02/10/1885.

- Relatório do Presidente da Província do Espírito Santo Antonio Joaquim Rodrigues, de 22/10/1885.

\section{Fontes manuscritas}

Documentação cartorial:

- Cartório do Primeiro Ofício da Comarca de São Mateus ou Cartório Arnaldo Bastos. Pesquisa baseada em 698 documentos referentes à escravidão. Entre estes, 172 Cartas de Liberdade, 460 escrituras de compra e venda de escravos e 66 documentos avulsos relativos à hipoteca, penhora, permuta, doações de escravos, dentre outros. 


\section{BIBLIOGRAFIA}

AGUIAR, Maciel de. Os últimos Zumbis: a saga dos negros do Vale do Cricaré durante a escravidão. Porto Seguro: Brasil-Cultura, 2001.

ALMADA, Vilma Ferreira de. Escravismo e Transição: o Espírito Santo (1850-1888). R.J. : Ed. Graal, 1984.

BERTIN, Enidelce. Alforrias na São Paulo do século XIX: Liberdade e dominação. S.P.: Humanitas/USP/FFLCH, 2004.

BERGARD, Lair W. Escravidão e História Econômica - demografia de Minas Gerais, 1720-1888. Bauru: EDUSC, 2004.

BICHARA, Terezinha T. História do Poder Legislativo no Espírito Santo (1835-1889). Vitória: Assembléia Legislativa/ Graf. Leoprint Indústria Ltda, 1984.

BORGES, Clério José. A Revolta do Queimado - Negros em busca de liberdade. Livro de História da Serra. Serra/ES: Edições do autor, 1998.

CAMPOS, Adriana Pereira. As alforrias na comarca de Vitória - séc. XIX. Dimensões Revista de História da Ufes. Vitória: UFES, 2004, n. 16.

. Escravidão e Creolização: a Capitania do Espírito Santo, 1790-1815. In: FRAGOSO, FLORENTINO, JUCÁ e CAMPOS (orgs.) Nas Rotas do Império. Vitória: EDUFES, 2006.

- Nas barras dos tribunais: escravidão e Direito na Província do Espírito Santo, século XIX. (Tese de doutorado). R. J. , UFRJ/PPGHIS, 2003.

CAPRINI, Aldieris B. A.. O comércio como propulsor do poder político em Iconha: o Coronel Antonio Duarte (1889-1915). Dissertação de Mestrado. Vitória:UFES/PPGHIS, 2007.

CARDOSO, Ciro F. (org.) Escravidão e abolição no Brasil: novas perspectivas. R.J..: Jorge Zahar Ed., 1988.

A brecha camponesa no sistema escravista. In: Agricultura, escravidão e capitalismo. Petrópolis: Vozes, 1979. 
CASTRO, Antonio Barros de. Escravos e senhores nos engenhos do Brasil: um estudo sobre os trabalhos do açúcar e a política econômica dos senhores. In: Estudos Econômicos. São Paulo: FEA/USP, v. 7, n. 1, 1977.

CASTRO, Hebe M. Mattos de. Das cores do silêncio: os significados da liberdade no sudeste escravista - Brasil séc. XIX. Rio de Janeiro: Arquivo Nacional, 1995.

História Social. In: CARDOSO, Ciro F. S. e VAINFAS, R (orgs). Domínios da História: ensaios de teoria e metodologia. Rio de Janeiro: Campus, 1997.

CLÁUDIO, Afonso. Insurreição do Queimado. Episódio da História da Província do Espírito Santo. Vitória, Fund. Ceciliano Abel de Almeida, 1979.

CÔGO, Anna Lúcia. História Agrária do Espírito Santo no século XIX: a região de São Mateus. Tese de Doutorado. FFLCH/USP, 2007

CONRAD, Robert. Os Últimos Anos da Escravatura no Brasil (1850-1888). R.J.: Civilização Brasileira, 1978.

CONSTANTE, Armando de Melo Servo. Comércio de escravos em Sant'Anna de Mogy das Cruzes na segunda metade do século XIX - 1864/1887. In: Anais do XVII Encontro Regional de História - O Lugar da História. ANPUH/SP - UNICAMP: Campinas, 2004.

COSTA, I. del Nero da. Arraia-miúda: um estudo sobre os não-proprietários de escravos no Brasil. São Paulo: MGSP, 1992.

\& PIRES, J. M. A fórmula do capital escravista-mercantil. In: Estudos Econômicos. São Paulo: FEA/USP, v. 24, n.3, 1994.

CUNHA, Eduardo Durão. São Mateus e sua História. In: São Mateus - Espírito Santo: 450 anos. São Mateus: EDAL, 1994.

CUNHA, Manuela Carneiro. Sobre os silêncios da lei. Lei costumeira e positiva nas alforrias de escravos no Brasil do século XIX. Cadernos Campinas. Campinas: IFCHUNICAMP, abr.1983.

DAEMON, Basílio C. Estatística e História da Província do Espírito Santo. Vitória, 1879. 
História da Província do Espírito Santo: sua descoberta, história cronológica, synopsis e estatísitica. Vitória, Typografia Espírito-Santense, 1886.

DAUWE, Fabiano. A libertação gradual e a saída viável: os múltiplos sentidos da liberdade pelo fundo de emancipação de escravos. Dissertação de Mestrado/UFF, 2004.

EISENBERG, Peter L. Homens esquecidos: escravos e trabalhadores livres no Brasil séc. XVIII e XIX. Campinas: Ed. da UNICAMP, 1989.

FLORENTINO, Manolo. Alforrias e etnicidade no Rio de Janeiro oitocentista: notas de pesquisa. TOPOI. Revista de História. R.J., UFRJ/ 7 Letras, n.5, 2002.

Em Costas Negras - Uma história do tráfico de escravos entre a África e o Rio de Janeiro. São Paulo: Companhia das Letras, 1997.

FRAGOSO, J. L. R. et alli (orgs.) Nas Rotas do Império: eixos mercantis, tráfico e relações sociais no mundo português. Vitória: EDUFES, 2006.

FREYRE, Gilberto. Sobrados e Mucambos., 14ª . ed., São Paulo: Global Editora, 2003.

GALIZA, Diana Soares. O Declínio da Escravidão na Paraíba (1850 -1888). João Pessoa: Ed. Universitária/UFPB, 1979.

GÓES, J. Roberto Pinto de. Padrões de alforrias no Rio de Janeiro - 1841/1871. In: FRAGOSO, FLORENTINO, JUCÁ e CAMPOS (orgs.). Nas Rotas do Império. Vitória: EDUFES, 2006.

GOMES, Alessandra Caetano. Em busca da liberdade: as alforrias em duas regiões do sudeste escravista, 1825-1888. Dissertação de Mestrado. São Paulo: USP/FFLCH, 2008.

GONÇALVES, Andréa Lisly. As margens da liberdade: alforrias na comarca de Ouro Preto (1808/ 1870). São Paulo: USP/FFLCH, 2000 (Tese de doutorado).

As margens da liberdade: alforrias em Minas Gerais na primeira metade do século XIX. In: LPH: Revista de História. Ouro Preto: UFOP, n.6, 1996, p. 200-208.

GORENDER, Jacob. O escravismo colonial. 4ª . ed., São Paulo, Ática, 1985. 
. A escravidão reabilitada. São Paulo: Ática, 1990.

GRAHAM, Richard. Clientelismo e política no Brasil do século XIX. R.J.: UFRJ, 1997.

GRINBERG, Keila. Alforria, Direito e Direitos no Brasil e nos Estados Unidos. Estudos Históricos, Rio de Janeiro, n. 27, 2001.

GUIMARÃES, Carlos Magno. Escravismo e rebeldia escrava: Quilombos nas Minas Gerais do século XVIII. In: SILVA, M. Beatriz Nizza da (org.). Brasil-Colonização e Escravidão. Rio de Janeiro: Nova fronteira, 2000.

GUTIÉRREZ, Horacio. Demografia escrava numa economia não-exportadora: Paraná, 1800-1830. Estudos econômicos, v.17, n.2, maio/ago.1987.

Crioulos e Africanos no Paraná, 1798 -1830. Revista Brasileira de História. São Paulo, v. 8, nº 16, mar. 88/ago.88.

JESUS, Aloiza Delurde Reali de. Comarca de Vitória: escravo de ganho e aluguel. (1850-1871). Monografia. Depto de História/UFES, 2006.

KARASCH, Mary. A vida dos escravos no Rio de Janeiro (1808-1850). São Paulo: Companhia das Letras, 2000.

KLEIN, Herbert S. \& PAIVA, Clotilde Andrade. Libertos em uma economia escravista: Minas Gerais em 1831. Estudos Econômicos, São Paulo, USP/IPE, v.27, n.2, 1997.

KNOX, Miridan B. Escravos do sertão - Demografia, trabalho e relações sociais: Piauí (1826-1888). Tese (Doutorado em História Social) FFLCH/USP, 1993.

LACERDA, Antonio H. D. Os padrões das alforrias em um município cafeeiro em Expansão (Juiz de Fora, Zona da Mata de Minas Gerais, 1844-88). São Paulo: FAPEB/Annablume, 2006.

LARA, Silvia Hunold. Campos da violência. São Paulo: Paz e Terra, 1988.

Ed. da UNICAMP, 2006.

e MENDONÇA, Joseli M. N. Direitos e Justiças no Brasil. Campinas: 
LEWKOWICZ, I.; GUTIÉRREZ, H.; FLORENTINO, M. Trabalho escravo e trabalho livre na história do Brasil. Sâo Paulo: Editora Unesp, 2008.

LUNA, F. V. \& KLEIN, H. Escravismo no Brasil. São Paulo: Edusp/Imprensa Oficial, 2010.

\& COSTA, Iraci Del Nero da. Escravismo em São Paulo e Minas Gerais. São Paulo :EDUSP/Imprensa Oficial, 2009.

MARCIS, Teresinha. Viagem ao Engenho de Santana. Ilhéus: Editus, 2000.

MARTINS, Robson L. M.. Em louvor a Sant'Anna: notas sobre um plano de revolta escrava em São Mateus, norte do Espírito Santo, Brasil, em 1884. Estudos afroasiáticos, n. 38, Rio de Janeiro, dez. 2000.

MATHIAS, Carlos Leonardo Kelmer. O movimento do crédito: o papel dos escravos nas relações de crédito, Rio de Janeiro e Minas Gerais (c. 1711 - c. 1756). In: Revista de História Regional 13(2): 2008.

MATTOSO, Kátia M. de Queirós. Ser escravo no Brasil. São Paulo: Brasiliense, 1982.

MELLO, Pedro Carvalho de Mello. A Economia da escravidão nas fazendas de café: 1850-1888. R.J.: PNPE,1984, mimeo, vol.I.

MOTTA, José Flavio \& MARCONDES, Renato L. Duas fontes documentais para o estudo dos preços dos escravos no Vale do Paraíba paulista. São Paulo. Revista Brasileira de História, v.21, n.42.

NARDOTO, Eliezer O. São Mateus: História, Turismo e Cultura. São Mateus, EDAL, 2005.

\& LIMA, Herinéia. História de São Mateus. São Mateus: EDAL, 1999.

NOVAES, Maria Stella de. A escravidão e a abolição no Espírito Santo: história e folclore. Vitória: departamento de Imprensa Oficial, 1963.

OLIVEIRA, José Teixeira de. História do Estado do Espírito Santo. Vitória, Fundação Cultural do Espírito Santo, 1975. 
OLIVEIRA, Saulo Veiga \& ODA, Ana Maria G. R. O suicídio de escravos em São Paulo nas últimas décadas da escravidão. Biblioteca on-line SCIELO (Bireme/FAPESP). Fonte: Alex Sander Alcântara / Agência FAPESP.

PAIVA, Eduardo França. Escravos e libertos nas Minas Gerais do século do século XVIII: estratégias de resistência através dos testamentos. São Paulo, Annablume, 1995.

Escravidão e universo cultural na colônia: Minas Gerais, 1716-1789. Belo Horizonte: Editora UFMG, 2001.

e IVO, Isnara Pereira (orgs.). Escravidão, mestiçagem e histórias comparadas. São Paulo: Anablume; Belo Horizonte: PPGH-UFMG; Vitória da Conquista: Edunesb, 2008.

PENA, Eduardo Spiller. Pajens da Casa Imperial, jurisconsultos, escravidão e a lei de 1871. Campinas, SP: Editora da Unicamp / Centro de Pesquisa em História Social da Cultura, 2001.

PIRES, J. M. \& COSTA, I. del Nero da. Considerações sobre o capital escravistamercantil. Estudos Econômicos, v.24, n.1, 1994.

n. 1. São Paulo: NEHD-FEA/USP, 1995.

O capital escravista-mercantil. Cadernos NEHD,

O capital escravista-mercantil: caracterização

teórica e causas históricas de sua superação. Estudos avançados, v.14, n. 38, 2000.

PIRES, M. de Fátima Novais. Cartas de alforria: para não ter o desgosto de ficar em cativeiro. Revista Brasileira de História. vol.26, n.52. São Paulo, Dec. 2006

PRADO JR., Caio. História Econômica do Brasil. S.P.: Brasiliense, 1985.

QUEIROZ, Maria Isaura Pereira de. O mandonismo local na vida política brasileira e outros ensaios. São Paulo, Alfa-Ômega, 1976.

REIS, João José. Rebelião escrava no Brasil: a história do levante dos malês (1835). São Paulo: Cia das Letras, 2003.

Escravidão e invenção da liberdade: estudos sobre o negro no Brasil. São Paulo: Brasiliense, 1988. 
e SILVA, Eduardo. Negociação e conflito: a resistência negra no Brasil escravista. São Paulo: Companhia das Letras, 1989.

e GOMES Flávio dos S. (org.). Liberdade por um Fio: História dos Quilombos no Brasil. Cia. das Letras: São Paulo, 1996.

REVISTA HISTÓRICA. São Mateus - Espírito Santo: 450 anos. São Mateus: EDAL, 1994.

REVISTA PALMARES. Quilombos no Brasil. Brasília: Fundação Cultural Palmares/MinC, 2000.

SALETTO, Nara. Transição para o trabalho livre e pequena propriedade no Espírito Santo. Vitória: EDUFES, 1996.

Trabalhadores Nacionais e Imigrantes no Mercado de Trabalho do Espírito Santo (1888-1930). Vitória: EDUFES, 1996.

SANTOS, Lucimar Felisberto dos. Os bastidores da lei: estratégias escravas e o Fundo de Emancipação. In: Revista de História, 1, 2 (2009).

SCHWARTZ, Stuart B. Escravos, roceiros e rebeldes. Bauru: EDUSC, 2001.

Segredos Internos: Engenhos e escravos na sociedade colonial.

São Paulo: Companhia das Letras, 2005.

SILVA, E. \& REIS, João J. Negociação e conflito: a resistência negra no Brasil escravista. São Paulo: Cia das Letras, 1989.

SILVA, Maria Beatriz Nizza da (Org.). Brasil - colonização e escravidão. Rio de Janeiro: Nova fronteira, 2000.

SILVA, Sandro José da. Quilombolas no Espírito Santo: identidade e territorialidade. Dimensões - Revista de História da UFES, n.18, 2006, p. 272 - 300.

SOUZA, Laura de Mello e. Coartação - problemática e episódios referentes a Minas Gerais no século XVIII. In: Norma e Conflito: Aspectos da História de Minas no século XVIII. B.H/SP: Ed. UFMG/ Humanitas, 1999. 
SOUZA, Marina de Mello e. África e Brasil Africano. São Paulo: Ed. Ática, 2a . ed., 2009.

Reis negros no Brasil escravista: história da festa de coroação de rei congo. Belo Horizonte/São Paulo: Ed.UFMG/Humanitas, 2006.

SLENES, Robert. Na senzala uma flor: esperanças e recordações na formação da família escrava. Brasil sudeste, século XIX. Rio de Janeiro: Nova Fronteira (Coleção História do Brasil), 1999.

A Árvore Nsanda Transplantada: Cultos Kongo de Aflição e Identidade escrava no Sudeste Brasileiro (séc. XIX). In. LIBBY, D.C. e FURTADO, J. F. (org.). Trabalho livre, trabalho escravo: Brasil e Europa, séculos XVII e XIX. São Paulo: Anablume, 2006.

VASCONCELLOS, Ignácio Accioli de. Memoria Statistica da Província do Espírito Santo escrita no ano de 1828. Col. 'Mário Aristides Freire', v.1, Vitória: Arquivo Público Estadual, 1978. 
ANEXOS 


\section{ANEXO 1}

Tabela 1: Nome dos escravos nas cartas de alforrias em São Mateus (1863-1888).

\begin{tabular}{|c|c|c|c|}
\hline Nome do escravo & Frequência & Percentual & Percentual Acumulado \\
\hline Maria & 8 & 4,7 & 4,7 \\
\hline Francisco & 4 & 2,3 & 7,0 \\
\hline Francisca & 4 & 2,3 & 9,3 \\
\hline João & 3 & 1,7 & 11,0 \\
\hline Severina & 3 & 1,7 & 12,8 \\
\hline Rita & 2 & 1,2 & 14,0 \\
\hline Candido & 2 & 1,2 & 15,1 \\
\hline Constança & 2 & 1,2 & 16,3 \\
\hline Serafina & 2 & 1,2 & 17,4 \\
\hline Theodorico & 2 & 1,2 & 18,6 \\
\hline Rufina & 2 & 1,2 & 19,8 \\
\hline Thereza & 2 & 1,2 & 20,9 \\
\hline Carolina & 2 & 1,2 & 22,1 \\
\hline Benedicta & 2 & 1,2 & 23,3 \\
\hline Januária & 2 & 1,2 & 24,4 \\
\hline Magdalena & 2 & 1,2 & 25,6 \\
\hline Rosinda & 2 & 1,2 & 26,7 \\
\hline Florencia & 2 & 1,2 & 27,9 \\
\hline Honorato & 2 & 1,2 & 29,1 \\
\hline Rosa & 2 & 1,2 & 30,2 \\
\hline Genoveva & 2 & 1,2 & 31,4 \\
\hline Sebastião & 2 & 1,2 & 32,6 \\
\hline Virginia & 2 & 1,2 & 33,7 \\
\hline Ricardo & 2 & 1,2 & 34,9 \\
\hline Antonio & 2 & 1,2 & 36,0 \\
\hline Marcolina & 2 & 1,2 & 37,2 \\
\hline Guilhermina & 1 & 0,6 & 37,8 \\
\hline Iria & 1 & 0,6 & 38,4 \\
\hline Catharina* & 1 & 0,6 & 39,0 \\
\hline Thomas & 1 & 0,6 & 39,5 \\
\hline Joanna & 1 & 0,6 & 40,1 \\
\hline Luzia & 1 & 0,6 & 40,7 \\
\hline Felicissimo & 1 & 0,6 & 41,3 \\
\hline Idalina & 1 & 0,6 & 41,9 \\
\hline Geur & 1 & 0,6 & 42,4 \\
\hline Maria* & 1 & 0,6 & 43,0 \\
\hline Macário & 1 & 0,6 & 43,6 \\
\hline Rogesino & 1 & 0,6 & 44,2 \\
\hline Elvira & 1 & 0,6 & 44,8 \\
\hline Fé & 1 & 0,6 & 45,3 \\
\hline Alexandre & 1 & 0,6 & 45,9 \\
\hline Luís & 1 & 0,6 & 46,5 \\
\hline Filisarda & 1 & 0,6 & 47,1 \\
\hline Catharina & 1 & 0,6 & 47,7 \\
\hline Floriana & 1 & 0,6 & 48,3 \\
\hline Aprigio & 1 & 0,6 & 48,8 \\
\hline Luisa* & 1 & 0,6 & 49,4 \\
\hline Manoel Jorge & 1 & 0,6 & 50,0 \\
\hline Honório & 1 & 0,6 & 50,6 \\
\hline Ladislau & 1 & 0,6 & 51,2 \\
\hline Piedade & 1 & 0,6 & 51,7 \\
\hline Anna & 1 & 0,6 & 52,3 \\
\hline Arminda & 1 & 0,6 & 52,9 \\
\hline Simoa & 1 & 0,6 & 53,5 \\
\hline Valeriana & 1 & 0,6 & 54,1 \\
\hline Demetildes & 1 & 0,6 & 54,7 \\
\hline Emilia & 1 & 0,6 & 55,2 \\
\hline Manoel & 1 & 0,6 & 55,8 \\
\hline Joana & 1 & 0,6 & 56,4 \\
\hline César & 1 & 0,6 & 57,0 \\
\hline Cassiano & 1 & 0,6 & 57,6 \\
\hline Aureliana * & 1 & 0,6 & 58,1 \\
\hline Veríssimo & 1 & 0,6 & 58,7 \\
\hline Judith & 1 & 0,6 & 59,3 \\
\hline Bernardino & 1 & 0,6 & 59,9 \\
\hline Felícia * & 1 & 0,6 & 60,5 \\
\hline Esmerina & 1 & 0,6 & 61,0 \\
\hline
\end{tabular}




\begin{tabular}{|c|c|c|c|}
\hline Pedro & 1 & 0,6 & 61,6 \\
\hline Domingos & 1 & 0,6 & 62,2 \\
\hline Athanazio & 1 & 0,6 & 62,8 \\
\hline Edwige & 1 & 0,6 & 63,4 \\
\hline Vicencia & 1 & 0,6 & 64,0 \\
\hline Porcina & 1 & 0,6 & 64,5 \\
\hline Josefa & 1 & 0,6 & 65,1 \\
\hline Referina & 1 & 0,6 & 65,7 \\
\hline Innocencia & 1 & 0,6 & 66,3 \\
\hline Joaquina & 1 & 0,6 & 66,9 \\
\hline Joaquim & 1 & 0,6 & 67,4 \\
\hline Fausta & 1 & 0,6 & 68,0 \\
\hline Dorothéa & 1 & 0,6 & 68,6 \\
\hline Luis & 1 & 0,6 & 69,2 \\
\hline Raphaela & 1 & 0,6 & 69,8 \\
\hline Mariana & 1 & 0,6 & 70,3 \\
\hline Geraldino & 1 & 0,6 & 70,9 \\
\hline Marcolino & 1 & 0,6 & 71,5 \\
\hline Lucia & 1 & 0,6 & 72,1 \\
\hline Joaquina* & 1 & 0,6 & 72,7 \\
\hline Lucas & 1 & 0,6 & 73,3 \\
\hline Paulo & 1 & 0,6 & 73,8 \\
\hline Candida & 1 & 0,6 & 74,4 \\
\hline Damião & 1 & 0,6 & 75,0 \\
\hline Lesio & 1 & 0,6 & 75,6 \\
\hline Camila & 1 & 0,6 & 76,2 \\
\hline Constantino & 1 & 0,6 & 76,7 \\
\hline Ignácia & 1 & 0,6 & 77,3 \\
\hline Ignacia & 1 & 0,6 & 77,9 \\
\hline Jose & 1 & 0,6 & 78,5 \\
\hline Henrique & 1 & 0,6 & 79,1 \\
\hline Felismina & 1 & 0,6 & 79,7 \\
\hline Victorio & 1 & 0,6 & 80,2 \\
\hline Jesuina & 1 & 0,6 & 80,8 \\
\hline Aldina & 1 & 0,6 & 81,4 \\
\hline Durcolina & 1 & 0,6 & 82,0 \\
\hline Dorothea & 1 & 0,6 & 82,6 \\
\hline Andrelino & 1 & 0,6 & 83,1 \\
\hline Rosalina & 1 & 0,6 & 83,7 \\
\hline Quitéria & 1 & 0,6 & 84,3 \\
\hline Raymundo & 1 & 0,6 & 84,9 \\
\hline Laura & 1 & 0,6 & 85,5 \\
\hline Malaquias & 1 & 0,6 & 86,0 \\
\hline Arnalda & 1 & 0,6 & 86,6 \\
\hline Avelina & 1 & 0,6 & 87,2 \\
\hline Adão & 1 & 0,6 & 87,8 \\
\hline Filipina & 1 & 0,6 & 88,4 \\
\hline Felicíssimo & 1 & 0,6 & 89,0 \\
\hline Rosinha & 1 & 0,6 & 89,5 \\
\hline Felippe & 1 & 0,6 & 90,1 \\
\hline Daniel & 1 & 0,6 & 90,7 \\
\hline Julianna & 1 & 0,6 & 91,3 \\
\hline Manoel Braz & 1 & 0,6 & 91,9 \\
\hline Eugenio & 1 & 0,6 & 92,4 \\
\hline Anastácia* & 1 & 0,6 & 93,0 \\
\hline Angelica & 1 & 0,6 & 93,6 \\
\hline Delmira & 1 & 0,6 & 94,2 \\
\hline Faustina & 1 & 0,6 & 94,8 \\
\hline Leocadia & 1 & 0,6 & 95,3 \\
\hline Demétrio & 1 & 0,6 & 95,9 \\
\hline Marcelina & 1 & 0,6 & 96,5 \\
\hline Lourença & 1 & 0,6 & 97,1 \\
\hline Izabel & 1 & 0,6 & 97,7 \\
\hline Felicidade & 1 & 0,6 & 98,3 \\
\hline Verediana & 1 & 0,6 & 98,8 \\
\hline Silvania & 1 & 0,6 & 99,4 \\
\hline Domingas & 1 & 0,6 & 100,0 \\
\hline Total & 172 & 100,0 & $\sigma_{1}$ \\
\hline
\end{tabular}




\section{ANEXO 2}

Tabela 1: Idade e sexo dos escravos comprados/vendidos em São Mateus

\begin{tabular}{|c|c|c|c|c|c|}
\hline \multirow{2}{*}{$\begin{array}{l}\text { Idade } \\
\text { do } \\
\text { escravo }\end{array}$} & \multicolumn{3}{|c|}{ Sexo do escravo } & \multirow[t]{2}{*}{ Total } & \multirow[t]{2}{*}{$\%$} \\
\hline & Não se sabe & Homens & Mulheres & & \\
\hline 1 & - & 1 & 1 & 2 & 0,3 \\
\hline 2 & - & 1 & 1 & 2 & 0,3 \\
\hline 3 & - & 4 & 1 & 5 & 0,8 \\
\hline 4 & - & - & 2 & 2 & 0,3 \\
\hline 5 & - & 1 & - & 1 & 0,2 \\
\hline 6 & - & 3 & 1 & 4 & 0,7 \\
\hline 7 & - & 1 & 4 & 5 & 0,8 \\
\hline 8 & - & 4 & 2 & 6 & 1,0 \\
\hline 9 & - & - & 1 & 1 & 0,2 \\
\hline 10 & - & 2 & 2 & 4 & 0,7 \\
\hline 11 & - & 2 & 1 & 3 & 0,5 \\
\hline 12 & - & 3 & 2 & 5 & 0,8 \\
\hline 13 & - & 3 & 4 & 7 & 1,2 \\
\hline 14 & - & - & - & - & 0,7 \\
\hline 15 & - & 2 & 2 & 4 & 0,7 \\
\hline 16 & - & 6 & 5 & 11 & 1,8 \\
\hline 17 & - & - & 2 & 2 & 0,3 \\
\hline 18 & - & 4 & 5 & 9 & 1,5 \\
\hline 19 & - & 3 & 1 & 4 & 0,7 \\
\hline 20 & - & 8 & 10 & 18 & 3,0 \\
\hline 21 & - & 2 & 3 & 5 & 0,8 \\
\hline 22 & - & 5 & 3 & 8 & 1,3 \\
\hline 23 & - & 1 & 2 & 3 & 0,5 \\
\hline 24 & - & 1 & 2 & 3 & 0,5 \\
\hline 25 & - & 17 & 10 & 27 & 4,5 \\
\hline 26 & - & 2 & 1 & 3 & 0,5 \\
\hline 27 & - & 1 & 1 & 2 & 0,3 \\
\hline 28 & - & 1 & 1 & 2 & 0,3 \\
\hline 29 & - & 1 & 1 & 2 & 0,3 \\
\hline 30 & - & 7 & 10 & 17 & 2,8 \\
\hline 31 & - & 1 & 1 & 2 & 0,3 \\
\hline 32 & - & 1 & - & 1 & 0,2 \\
\hline 35 & - & 2 & 3 & 5 & 0,8 \\
\hline 36 & - & - & 1 & 1 & 0,2 \\
\hline 37 & - & - & 1 & 1 & 0,2 \\
\hline 38 & - & 1 & 2 & 3 & 0,5 \\
\hline 40 & - & 7 & 9 & 16 & 2,6 \\
\hline 41 & - & 5 & - & 5 & 1,0 \\
\hline 45 & - & 3 & 2 & 5 & 0,8 \\
\hline 46 & - & 1 & - & 1 & 0,2 \\
\hline 50 & - & 4 & 2 & 6 & 1,0 \\
\hline 51 & - & - & 1 & 1 & 0,2 \\
\hline 60 & - & 2 & 1 & 3 & 0,5 \\
\hline 70 & - & 1 & - & 1 & 0,2 \\
\hline Nada consta & 11 & 213 & 164 & 388 & 64,0 \\
\hline Total & 11 & 326 & 269 & 606 & 100,0 \\
\hline
\end{tabular}

Fonte: Cartório de 1o Ofício de São Mateus. 
Tabela 2: Preços dos escravos comprados/vendidos em São Mateus (1863-1887).

\begin{tabular}{|c|c|c|}
\hline $\begin{array}{l}\text { Preço do escravo } \\
\text { (em réis) }\end{array}$ & Frequência & Percentual \\
\hline $80 \$ 000$ & 51 & 8,4 \\
\hline $100 \$ 000$ & 1 & 0,2 \\
\hline $150 \$ 000$ & 1 & 0,2 \\
\hline $157 \$ 000$ & 1 & 0,2 \\
\hline $200 \$ 000$ & 5 & 0,8 \\
\hline $202 \$ 000$ & 3 & 0,5 \\
\hline $250 \$ 000$ & 2 & 0,3 \\
\hline $300 \$ 000$ & 7 & 1,2 \\
\hline $320 \$ 000$ & 1 & 0,2 \\
\hline $350 \$ 000$ & 9 & 1,5 \\
\hline $370 \$ 000$ & 1 & 0,2 \\
\hline $380 \$ 000$ & 1 & 0,2 \\
\hline $400 \$ 000$ & 11 & 1,8 \\
\hline $450 \$ 000$ & 7 & 1,2 \\
\hline $452 \$ 492$ & 1 & 0,2 \\
\hline $500 \$ 000$ & 37 & 5,8 \\
\hline $516 \$ 667$ & 3 & 0,5 \\
\hline $525 \$ 000$ & 6 & 1,0 \\
\hline $530 \$ 000$ & 2 & 0,3 \\
\hline $540 \$ 000$ & 1 & 0,2 \\
\hline $550 \$ 000$ & 1 & 0,2 \\
\hline $600 \$ 000$ & 35 & 5,8 \\
\hline $636 \$ 364$ & 11 & 1,8 \\
\hline $650 \$ 000$ & 5 & 0,8 \\
\hline $666 \$ 500$ & 2 & 0,3 \\
\hline $670 \$ 000$ & 2 & 0,3 \\
\hline $700 \$ 000$ & 18 & 3,0 \\
\hline $705 \$ 000$ & 1 & 0,2 \\
\hline $736 \$ 000$ & 1 & 0,2 \\
\hline $750 \$ 000$ & 5 & 0,8 \\
\hline $760 \$ 000$ & 10 & 1,7 \\
\hline $800 \$ 000$ & 31 & 5,1 \\
\hline $850 \$ 000$ & 5 & 0,8 \\
\hline $900 \$ 000$ & 28 & 4,6 \\
\hline $925 \$ 000$ & 4 & 0,7 \\
\hline $950 \$ 000$ & 4 & 0,7 \\
\hline $980 \$ 000$ & 1 & 0,2 \\
\hline $1: 000 \$ 000$ & 60 & 10,1 \\
\hline 1:020\$000 & 1 & 0,2 \\
\hline 1:040\$000 & 1 & 0,2 \\
\hline 1:050\$000 & 5 & 0,8 \\
\hline 1:090\$909 & 8 & 1,3 \\
\hline $1: 100 \$ 000$ & 20 & 3,3 \\
\hline $1: 150 \$ 000$ & 6 & 1,0 \\
\hline $1: 200 \$ 000$ & 42 & 7,1 \\
\hline $1: 230 \$ 000$ & 1 & 0,2 \\
\hline $1: 250 \$ 000$ & 9 & 1,5 \\
\hline $1: 300 \$ 000$ & 27 & 4,8 \\
\hline $1: 332 \$ 000$ & 1 & 0,2 \\
\hline $1: 333 \$ 000$ & 6 & 1,0 \\
\hline $1: 335 \$ 000$ & 1 & 0,2 \\
\hline $1: 350 \$ 000$ & 4 & 0,7 \\
\hline $1: 400 \$ 000$ & 34 & 5,6 \\
\hline $1: 450 \$ 000$ & 1 & 0,2 \\
\hline
\end{tabular}




\begin{tabular}{lrr}
$1: 475 \$ 000$ & 1 & 0,2 \\
$1: 500 \$ 000$ & 22 & 3,6 \\
$1: 525 \$ 000$ & 1 & 0,2 \\
$1: 550 \$ 000$ & 4 & 0,7 \\
$1: 600 \$ 000$ & 12 & 2,0 \\
$1: 638 \$ 000$ & 1 & 0,2 \\
$1: 650 \$ 000$ & 4 & 0,7 \\
$1: 670 \$ 000$ & 1 & 0,2 \\
$1: 700 \$ 000$ & 5 & 0,8 \\
$1: 800 \$ 000$ & 5 & 0,8 \\
$1: 900 \$ 000$ & 1 & 0,2 \\
$2: 000 \$ 000$ & 1 & 0,2 \\
$2: 160 \$ 000$ & 1 & 0,2 \\
$2: 500 \$ 000$ & 1 & 0,2 \\
Nada consta & 4 & 0,7 \\
Total & 606 & 100,0 \\
\hline Fonte: Cartório de 19 Ofício de São Mateus.
\end{tabular}

Fonte: Cartório de 1o Ofício de São Mateus.

Tabela 3: Preços dos escravos comprados/vendidos por sexo em São Mateus (1863-1887).

\begin{tabular}{|c|c|c|c|c|}
\hline \multirow{2}{*}{$\begin{array}{l}\text { Preço do escravo } \\
\text { (em réis) }\end{array}$} & \multicolumn{2}{|c|}{ Sexo o escravo } & \multicolumn{2}{|r|}{ Total } \\
\hline & Mulheres & Homens & $\begin{array}{l}\text { Não se } \\
\text { sabe }\end{array}$ & \\
\hline $80 \$ 000$ & 26 & 24 & 1 & 51 \\
\hline $100 \$ 000$ & - & 1 & - & 1 \\
\hline $150 \$ 000$ & 1 & - & - & 1 \\
\hline $157 \$ 000$ & - & 1 & - & 1 \\
\hline $200 \$ 000$ & 2 & 3 & - & 5 \\
\hline $202 \$ 000$ & 1 & 2 & - & 3 \\
\hline $250 \$ 000$ & 2 & - & - & 2 \\
\hline $300 \$ 000$ & 4 & 3 & - & 7 \\
\hline $320 \$ 000$ & 1 & - & - & 1 \\
\hline $350 \$ 000$ & 3 & 6 & - & 9 \\
\hline $370 \$ 000$ & 1 & - & - & 1 \\
\hline $380 \$ 000$ & 1 & - & - & 1 \\
\hline $400 \$ 000$ & 3 & 7 & 1 & 11 \\
\hline $450 \$ 000$ & 4 & 3 & - & 7 \\
\hline $452 \$ 492$ & - & 1 & - & 1 \\
\hline $500 \$ 000$ & 16 & 19 & 2 & 37 \\
\hline $516 \$ 667$ & 2 & 1 & - & 3 \\
\hline $525 \$ 000$ & 3 & 3 & - & 6 \\
\hline $530 \$ 000$ & 1 & 1 & - & 2 \\
\hline $540 \$ 000$ & - & 1 & - & 1 \\
\hline $550 \$ 000$ & - & 1 & - & 1 \\
\hline $600 \$ 000$ & 18 & 17 & - & 35 \\
\hline $636 \$ 364$ & 4 & 7 & - & 11 \\
\hline $650 \$ 000$ & 4 & 1 & - & 5 \\
\hline $666 \$ 500$ & - & 2 & - & 2 \\
\hline $670 \$ 000$ & - & 2 & - & 2 \\
\hline $700 \$ 000$ & 8 & 10 & - & 18 \\
\hline $705 \$ 000$ & 1 & - & - & 1 \\
\hline $736 \$ 000$ & 1 & - & - & 1 \\
\hline $750 \$ 000$ & 2 & 3 & - & 5 \\
\hline $760 \$ 000$ & 3 & 7 & - & 10 \\
\hline $800 \$ 000$ & 12 & 19 & - & 31 \\
\hline
\end{tabular}




\begin{tabular}{|c|c|c|c|c|}
\hline $850 \$ 000$ & 3 & 2 & - & 5 \\
\hline $900 \$ 000$ & 13 & 15 & - & 28 \\
\hline $925 \$ 000$ & 3 & 1 & - & 4 \\
\hline $950 \$ 000$ & 3 & 1 & - & 4 \\
\hline $980 \$ 000$ & 1 & - & - & 1 \\
\hline $1: 000 \$ 000$ & 35 & 25 & - & 60 \\
\hline $1: 020 \$ 000$ & 1 & - & - & 1 \\
\hline $1: 040 \$ 000$ & 1 & - & - & 1 \\
\hline $1: 050 \$ 000$ & 3 & 2 & - & 5 \\
\hline 1:090\$909 & - & 1 & 7 & 8 \\
\hline $1: 100 \$ 000$ & 8 & 12 & - & 20 \\
\hline $1: 150 \$ 000$ & 4 & 2 & - & 6 \\
\hline $1: 200 \$ 000$ & 24 & 18 & - & 42 \\
\hline $1: 230 \$ 000$ & - & 1 & - & 1 \\
\hline $1250 \$ 000$ & 4 & 5 & - & 9 \\
\hline $1: 300 \$ 000$ & 10 & 17 & - & 27 \\
\hline $1: 332 \$ 000$ & - & 1 & - & 1 \\
\hline $1: 333 \$ 000$ & 2 & 4 & - & 6 \\
\hline $1: 335 \$ 000$ & - & 1 & - & 1 \\
\hline $1: 350 \$ 000$ & 1 & 3 & - & 4 \\
\hline $1: 400 \$ 000$ & 10 & 24 & - & 34 \\
\hline $1: 450 \$ 000$ & - & 1 & - & 1 \\
\hline $1: 475 \$ 000$ & - & 1 & - & 1 \\
\hline $1: 500 \$ 000$ & 8 & 14 & - & 22 \\
\hline $1: 525 \$ 000$ & - & 1 & - & 1 \\
\hline $1: 550 \$ 000$ & 1 & 3 & - & 4 \\
\hline $1: 600 \$ 000$ & 3 & 9 & - & 12 \\
\hline $1: 638 \$ 000$ & - & 1 & - & 1 \\
\hline $1: 650 \$ 000$ & 2 & 2 & - & 4 \\
\hline $1: 670 \$ 000$ & - & 1 & - & 1 \\
\hline $1: 700 \$ 000$ & - & 5 & - & 5 \\
\hline $1: 800 \$ 000$ & 1 & 4 & - & 5 \\
\hline $1: 900 \$ 000$ & - & 1 & - & 1 \\
\hline $2: 000 \$ 000$ & 1 & - & - & 1 \\
\hline $2: 160 \$ 000$ & - & 1 & - & 1 \\
\hline $2: 500 \$ 000$ & 1 & - & - & 1 \\
\hline Nada consta & 2 & 2 & - & 4 \\
\hline Total & 269 & 326 & 11 & 606 \\
\hline
\end{tabular}

Fonte: Cartório de 1o Ofício de São Mateus.

Tabela 4: Preços dos escravos por décadas e por sexo em São Mateus (1863-1887). 
\begin{tabular}{ll} 
& \\
\hline SEXO & PREÇO \\
DO & DO
\end{tabular}

ESCRAVO ESCRA-

VO

(em réis)

REGISTROS POR DÉCADAS/ANOS RESPECTIVOS

(DÉCADA DE 1860/POR ANOS) ～(DÉCADA DE 1870/POR ANOS)

(DÉCADA DE 1880/POR ANOS)

TOTAL

$\begin{array}{lllllllllllllllllllllllll}1863 & 64 & 65 & 66 & 67 & 68 & 69 & 1870 & 71 & 72 & 73 & 74 & 75 & 76 & 77 & 78 & 79 & 1880 & 81 & 82 & 83 & 84 & 85 & 86 & 87\end{array}$

\begin{tabular}{|r|r|c|c|c|c|c|c|c|c|c|c|c|c|c|c|c|c|c|c|c|c|c|c|c|c|c|c|}
\hline 80000 & - & 1 & 1 & - & 8 & - & - & 3 & - & 4 & 6 & - & - & - & 1 & - & - & - & - & - & - & - & - & - & - & 24 \\
100000 & - & - & - & - & - & 1 & - & - & - & - & - & - & - & - & - & - & - & - & - & - & - & - & - & - & - & -1 \\
\hline 157000 & - & - & - & - & - & - & - & - & - & - & - & 1 & - & - & - & - & - & - & - & - & - & - & - & - & - & -1 \\
\hline 200000 & - & - & - & - & - & - & - & - & - & - & 1 & 1 & - & - & 1 & - & - & - & - & - & - & - & - & - & - & - \\
\hline 202000 & - & - & - & - & - & - & - & - & - & - & - & 2 & - & - & - & - & - & - & - & - & - & - & - & - & - & 2 \\
\hline
\end{tabular}

300000

350000

400000

450000

452492

500000

516667

525000

530000

540000

600000

636364

650000

666500

670000

700000

750000

760000

800000

850000

900000

925000

950000

1000000

1050000

1090909

1100000

1150000

1230000

1250000

1300000

1332000

1333000

1335000

1350000

1400000

1450000

1475000

1500000

1525000

1550000

1600000

1638000

1650000

1670000

1700000

1800000

1900000

2160000

Nada

consta

Total

\section{2}

\begin{tabular}{l|l}
\hline- & - \\
\hline- & - \\
\hline 2 & - \\
- & -
\end{tabular}

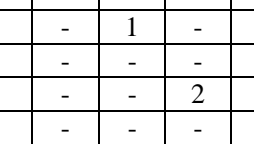

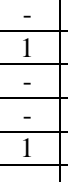

\begin{tabular}{c|c|c|c|c|c} 
& - & - & - & - & \\
\hline & 1 & - & 2 & 1 & - \\
- & - & - & - & - & - \\
- & - & - & - & 1 & - \\
- & - & 2 & 2 & 1 & \\
- & - & - & - & - & - \\
\hline
\end{tabular}

\begin{tabular}{l|l|l|}
1 & 1 & 2 \\
\hline & - & - \\
\hline
\end{tabular}

\begin{tabular}{|c|c|}
\hline- & - \\
\hline- & - \\
- & - \\
- & - \\
\hline- & 1 \\
\hline & -
\end{tabular}

\begin{tabular}{|c|c|c|c|c|c|c|c|}
\hline- & - & - & - & - & - & - & - \\
\hline- & - & - & - & - & - & - & - \\
\hline- & - & 1 & - & - & - & 1 & - \\
\hline 1 & 2 & - & 1 & 1 & - & 1 & 1 \\
- & - & - & - & - & - & - & -
\end{tabular}

\begin{tabular}{|c|c|c|c|c|c|c|c|}
\hline - & & & & & & & \\
\hline 4 & & & & & & & \\
\hline & - & - & 2 & 1 & 2 & - & 2 \\
\hline
\end{tabular}

\begin{tabular}{c|c|c|c|c|c} 
& - & - & - & - & - \\
\hline- & - & - & 2 & 1 & 1 \\
\hline- & - & - & - & - \\
\hline
\end{tabular}

\begin{tabular}{c|c|c|c|c|c|c|c}
- & - & - & - & - & 1 & - & - \\
\hline- & - & - & - & - & - & - & 2 \\
- & - & - & - & - & - & - & - \\
\hline & - & 1 & - & - & - & - & -
\end{tabular}

\begin{tabular}{l|l|l}
\hline- & - \\
\hline & - & 1 \\
\hline- & - \\
\hline- & - \\
\hline & - & \\
\hline & - & - \\
\hline
\end{tabular}




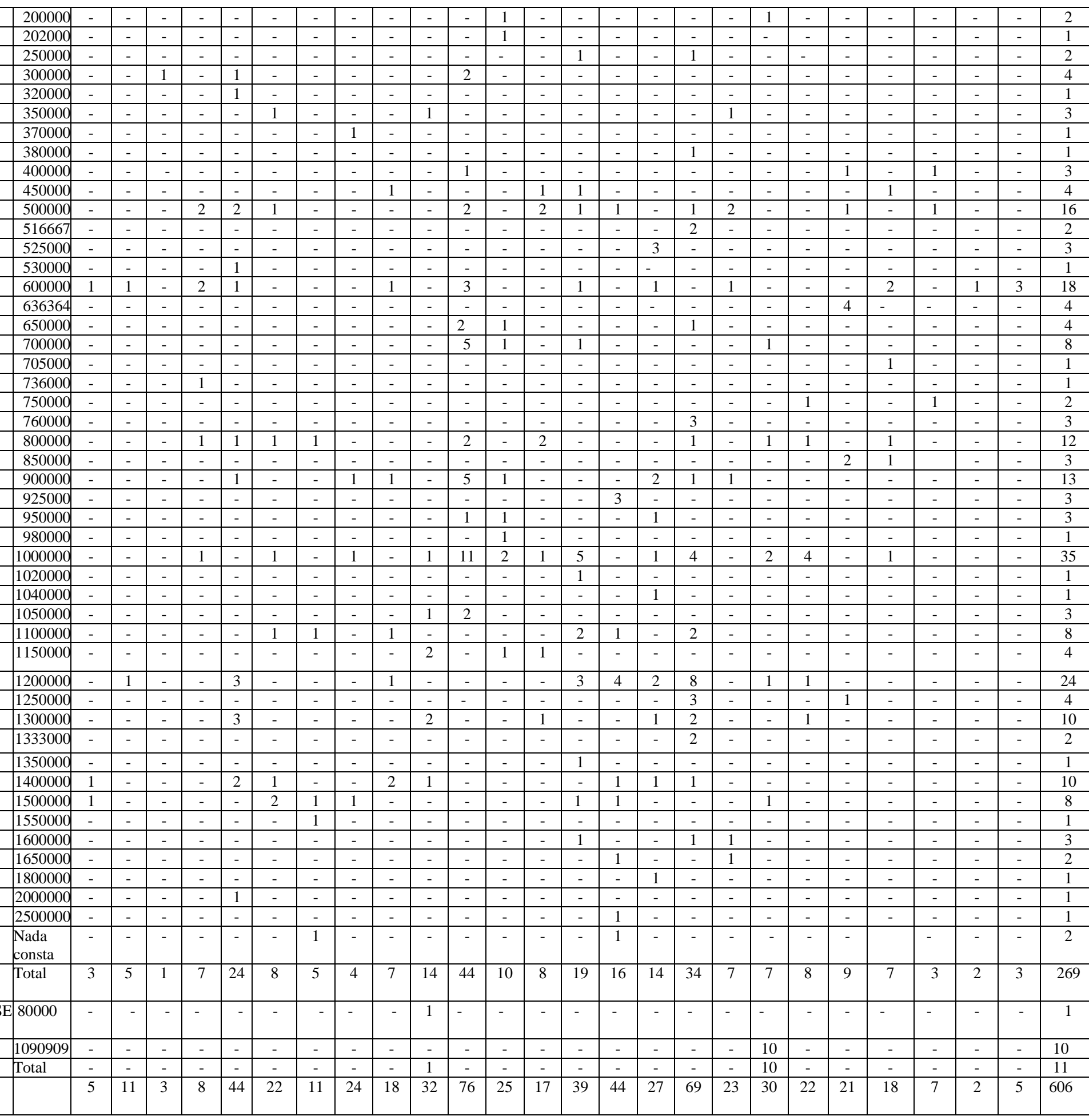




\section{ANEXO 3}

QUADRO 1: Credores e devedores nas hipotecas e penhoras de escravos em São Mateus (1866- 1885).

\begin{tabular}{|c|c|c|c|c|c|c|c|}
\hline $\mathbf{N}^{\circ}$ & Credor(es) & Devedor (es) & Data & $\begin{array}{l}\text { Tipo do } \\
\text { negócio }\end{array}$ & $\begin{array}{l}\text { Valor/bens } \\
\text { garantia }\end{array}$ & Livro & Folha \\
\hline 05 & $\begin{array}{l}\text { Reginaldo } \\
\text { Gomes dos } \\
\text { Santos }\end{array}$ & $\begin{array}{l}\text { Simplicio } \\
\text { Alfonço de } \\
\text { Barcellos e } \\
\text { sua mulher } \\
\text { Maria Ribeiro } \\
\text { da Conceição }\end{array}$ & $07 / 12 / 1866$ & $\begin{array}{lr}\text { Escritura } & \text { de } \\
\text { dívida } & \mathrm{e} \\
\text { hipoteca } & \end{array}$ & $\begin{array}{l}\text { Valor: não consta / } \\
\text { Garantia: entre outros } \\
\text { bens, figuram } 2 \text { escravas } \\
\text { (Vicência; e Benedita, com } \\
2 \text { crias. }\end{array}$ & 01 & 136 \\
\hline 15 & $\begin{array}{l}\text { Sebastião } \\
\text { José Barbosa } \\
\text { (outorgado) }\end{array}$ & $\begin{array}{l}\text { Francisco } \\
\text { Coutinho } \\
\text { d'Essa } \\
\text { (outorgante) }\end{array}$ & $17 / 09 / 1874$ & $\begin{array}{ll}\text { Escritura } & \text { de } \\
\text { penhor } & \text { da } \\
\text { escrava } & \end{array}$ & $\begin{array}{l}\text { Valor: } 700 \$ 000 . \\
\text { Garantia: } \\
\text { Severiana }\end{array}$ & 06 & 30 \\
\hline 17 & 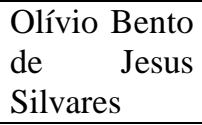 & $\begin{array}{l}\text { Anna Maria de } \\
\text { Oliveira } \\
\text { Chagas }\end{array}$ & $07 / 06 / 1877$ & Hipotecados... & $\begin{array}{l}\text { Valor: não consta. } \\
\text { Garantia: } 4 \text { escravos }\end{array}$ & 06 & 126 \\
\hline 18 & $\begin{array}{l}\text { Lourenço } \\
\text { Bernardo } \\
\text { Vieira } \\
\end{array}$ & $\begin{array}{lr}\text { Olívio } & \text { Bento } \\
\text { de } & \text { Jesus } \\
\text { Silvares } & \\
\end{array}$ & 14/06/1877 & $\begin{array}{l}\text { Escritura de } \\
\text { Hipoteca }\end{array}$ & $\begin{array}{l}\text { Valor: } 800 \$ 000 \text { / Garantia: } \\
\text { além de imóvel, também o } \\
\text { escravo Fortunato. }\end{array}$ & 06 & 129 \\
\hline 19 & $\begin{array}{l}\text { Lourenço } \\
\text { Bernardo } \\
\text { Vieira }\end{array}$ & $\begin{array}{lr}\text { Olívio } & \text { Bento } \\
\text { de } & \text { Jesus } \\
\text { Silvares } & \end{array}$ & $09 / 07 / 1877$ & $\begin{array}{l}\text { Escritura de } \\
\text { dação insolutum }\end{array}$ & $\begin{array}{l}\text { Valor: } 800 \$ 000=\text { o } \\
\text { escravo Fortunato foi } \\
\text { entregue c/ pagamento da } \\
\text { dívida de hipoteca (ver } \\
\text { linha acima) }\end{array}$ & 06 & $\begin{array}{l}131 \\
\text { verso }\end{array}$ \\
\hline 20 & $\begin{array}{l}\text { Antonio José } \\
\text { de Oliveira }\end{array}$ & $\begin{array}{l}\text { Matheus } \\
\text { Cantien }\end{array}$ & $04 / 01 / 1875$ & $\begin{array}{l}\text { Escritura } \quad \text { de } \\
\text { hipoteca }\end{array}$ & $\begin{array}{lcc}\text { Valor: não consta } & \text { / } \\
\text { Garantia: além de } & 1 \\
\text { imóvel, } & + & 4 \\
\text { escravos(Josepha, } & \\
\text { Benvindo, Marcos } & \text { e } \\
\text { Benedicto). } & & \\
\end{array}$ & 07 & 17 \\
\hline 21 & $\begin{array}{l}\text { FIRMA: } \\
\text { Fonseca, } \\
\text { Rios \& CIA }\end{array}$ & $\begin{array}{l}\text { Miguel } \\
\text { Ferreira } \\
\text { Custódio } \\
\text { Barbosa }\end{array}$ & $11 / 02 / 1875$ & $\begin{array}{l}\text { Empréstimo, } \\
\text { sob penhora }\end{array}$ & 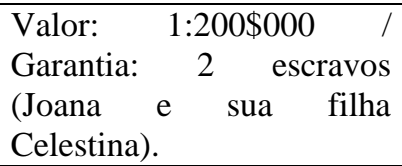 & 07 & 27 \\
\hline 25 & $\begin{array}{l}\text { FIRMA: } \\
\text { Fonseca, } \\
\text { Rios \& CIA }\end{array}$ & $\begin{array}{l}\text { Bernardino } \\
\text { Alves Pereira }\end{array}$ & $08 / 01 / 1876$ & $\begin{array}{l}\text { Escritura de } \\
\text { débito, s/ penhor }\end{array}$ & 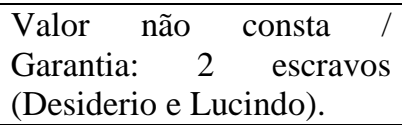 & 07 & 136 \\
\hline 28 & $\begin{array}{l}\text { Domingos } \\
\text { Rocha da } \\
\text { Silva Rios }\end{array}$ & $\begin{array}{l}\text { João de Jesus } \\
\text { Silvares Junior } \\
\text { e sua mulher } \\
\text { Claudiana } \\
\text { Maria da Silva }\end{array}$ & $26 / 04 / 1878$ & $\begin{array}{l}\text { Empréstimo, } \\
\text { débito } \quad \text { e } \\
\text { obrigação, sob } \\
\text { penhor }\end{array}$ & $\begin{array}{l}\text { Valor: } 2: 679 \$ 000 \\
\text { Garantia: } \\
\text { bens, }+\quad 3 \text { entre outros } \\
\text { (Francisco, Antonio e } \\
\text { Gervásio). }\end{array}$ & 07 & 383 \\
\hline 31 & $\begin{array}{l}\text { FIRMA: } \\
\text { Leonel } \\
\text { Joaquim de } \\
\text { Almeida } \\
\text { Fundão \& } \\
\text { CIA }\end{array}$ & $\begin{array}{l}\text { Manoel } \\
\text { Antonio de } \\
\text { Couto e sua } \\
\text { mulher }\end{array}$ & $10 / 08 / 1878$ & $\begin{array}{l}\text { Escritura de } \\
\text { garantia do } \\
\text { valor..., } \\
\text { mediante penhor } \\
\text { do escravo... }\end{array}$ & $\begin{array}{lr}\text { Valor: } & 1: 500 \$ 000 \\
\text { Garantia: } & \text { escravo } \\
\text { Torquato. } & \end{array}$ & 10 & $\begin{array}{l}41 \\
\text { verso }\end{array}$ \\
\hline 32 & $\begin{array}{l}\text { Não } \begin{array}{r}\text { consta } \\
\text { (mas deve }\end{array} \\
\text { ser o mesmo } \\
\text { acima } \\
\text { referido no } \\
\text { item 31) }\end{array}$ & $\begin{array}{l}\text { Manoel } \\
\text { Antonio de } \\
\text { Couto e sua } \\
\text { mulher }\end{array}$ & $11 / 09 / 1878$ & $\begin{array}{l}\text { Escritura } \\
\text { penhor }\end{array}$ & $\begin{array}{lr}\text { Valor: } & 1: 600 \$ 000 \\
\text { Garantia: } & \text { escravo } \\
\text { Torquato. } & \end{array}$ & 10 & 53 \\
\hline 33 & $\begin{array}{lr}\text { Não } & \text { consta } \\
\text { (mas } & \text { deve }\end{array}$ & $\begin{array}{l}\text { D. Maria de } \\
\text { Oliveira }\end{array}$ & $10 / 10 / 1878$ & $\begin{array}{l}\text { Escritura } \\
\text { hipoteca }\end{array}$ & $\begin{array}{l}\text { Valor: } 5: 281 \$ 505 \\
\text { Garantia: bens imóveis e } 2\end{array}$ & 10 & $\begin{array}{l}55 \\
\text { verso }\end{array}$ \\
\hline
\end{tabular}




\begin{tabular}{|c|c|c|c|c|c|c|c|}
\hline & $\begin{array}{l}\text { ser o mesmo } \\
\text { acima } \\
\text { referido no } \\
\text { item 31) }\end{array}$ & Chagas & & & $\begin{array}{lll}\text { escravos } & \text { (João } & \text { e } \\
\text { Theodora). } & & \end{array}$ & & \\
\hline 34 & $\begin{array}{l}\text { Cel. } \\
\text { Matheus } \\
\text { Antonio dos } \\
\text { Santos }\end{array}$ & $\begin{array}{l}\text { Manoel Pedro } \\
\text { Machado } \\
\text { Rangel e sua } \\
\text { mulher }\end{array}$ & $12 / 10 / 1878$ & $\begin{array}{lr}\begin{array}{l}\text { Escritura } \\
\text { débito }\end{array} \\
\text { hipoteca }\end{array}$ & $\begin{array}{lr}\text { Valor: } & 4: 000 \$ 000 \\
\text { Garantia: outros bens }+9 \\
\text { escravos } & \text { (Regosino, } \\
\text { Manoel, } & \text { Tiburcio, } \\
\text { Joaquina, etc.). } & \end{array}$ & 11 & 31 \\
\hline 35 & $\begin{array}{l}\text { FIRMA: } \\
\text { Fonseca, } \\
\text { Rios \& CIA }\end{array}$ & $\begin{array}{l}\text { Manoel José } \\
\text { Gonçalves e } \\
\text { sua mulher }\end{array}$ & $13 / 10 / 1878$ & $\begin{array}{lr}\text { Escritura } & \text { de } \\
\text { dívida } & \text { com } \\
\text { hipoteca } & \end{array}$ & $\begin{array}{l}\text { Valor: } 611 \$ 560 / \text { Garantia: } \\
\text { outros bens }+ \text { escrava } \\
\text { Filisdoria. }\end{array}$ & 11 & 33 \\
\hline 37 & $\begin{array}{l}\text { Tenente José } \\
\text { dos Santos } \\
\text { Neves }\end{array}$ & $\begin{array}{lr}\text { D. Ignacia } \\
\text { Maria da } \\
\text { Trindade } \\
\text { Bastos }\end{array}$ & $15 / 02 / 1879$ & $\begin{array}{ll}\begin{array}{l}\text { Escritura } \\
\text { débito, }\end{array} & \text { de } \\
\text { obrigação } & \mathrm{e} \\
\text { hipoteca } & \end{array}$ & $\begin{array}{l}\text { Valor: } 2: 686 \$ 000 \\
\text { Garantia: dentre outros } \\
\text { bens, } 18 \text { escravos. }\end{array}$ & 11 & 52 \\
\hline 39 & $\begin{array}{l}\text { Sebastião } \\
\text { José Barbosa }\end{array}$ & $\begin{array}{l}\text { Abílio Viega } \\
\text { Martins } \\
\text { Guimarães }\end{array}$ & $20 / 02 / 1880$ & $\begin{array}{l}\text { Escritura de } \\
\text { penhor }\end{array}$ & $\begin{array}{l}\text { Valor: } 800 \$ 000 . \\
\text { Garantia: escrava Maria. }\end{array}$ & 11 & 151 \\
\hline 40 & $\begin{array}{l}\text { Joaquim } \\
\text { Batista } \\
\text { Pequiá } \quad \text { e } \\
\text { outros (?) }\end{array}$ & $\begin{array}{l}\text { Reginaldo } \\
\text { Gomes dos } \\
\text { Santos }\end{array}$ & $16 / 04 / 1880$ & $\begin{array}{lr}\text { Confissão } & \text { de } \\
\text { dívida, } & \text { com } \\
\text { hipoteca } & \end{array}$ & $\begin{array}{l}\text { Valor: 7:527\$570. } \\
\text { Garantia: dentre outros } \\
\text { bens, }+3 \text { escravos. }\end{array}$ & 11 & $\begin{array}{l}155 \\
\text { verso }\end{array}$ \\
\hline 41 & Não consta... & $\begin{array}{l}\text { Francisco } \\
\text { Vicente de } \\
\text { Faria e sua } \\
\text { mulher } \\
\text { Ernestina } \\
\text { Maria de } \\
\text { Oliveira Faria }\end{array}$ & $26 / 04 / 1880$ & $\begin{array}{lr}\begin{array}{l}\text { Confissão } \\
\text { dívida, }\end{array} & \text { de } \\
\text { garantia } & \\
\text { hipotecária } & \end{array}$ & $\begin{array}{l}\text { Valor: 15:000\$000. } \\
\text { Garantia: imóveis e outros } \\
\text { bens, + } 5 \text { escravos. }\end{array}$ & 11 & 158 \\
\hline 42 & $\begin{array}{l}\text { José Alves } \\
\text { da Fonseca }\end{array}$ & $\begin{array}{l}\text { José Cosme da } \\
\text { Motta }\end{array}$ & $18 / 05 / 1880$ & 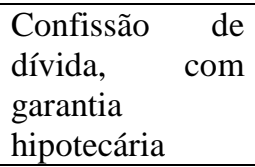 & $\begin{array}{l}\text { Valor: } 15: 000 \$ 000 . \\
\text { Garantia: bens imóveis, } \\
\text { semoventes }+7 \text { escravos. }\end{array}$ & 12 & $\begin{array}{l}166 \\
\text { verso }\end{array}$ \\
\hline 45 & $\begin{array}{l}\text { Olindo } \\
\text { Antonio dos } \\
\text { Santos }\end{array}$ & $\begin{array}{l}\text { José Antonio } \\
\text { de Faria e sua } \\
\text { mulher D. } \\
\text { Anna Amélia } \\
\text { C. Faria }\end{array}$ & $20 / 05 / 1880$ & $\begin{array}{lr}\text { Confissão } & \text { de } \\
\text { dívida, } & \text { com } \\
\text { hipoteca } & \end{array}$ & $\begin{array}{l}\text { Valor: 7:000\$000. } \\
\text { Garantia: outros bens }+7 \\
\text { escravos }\end{array}$ & 12 & $\begin{array}{l}8 \\
\text { verso }\end{array}$ \\
\hline 46 & $\begin{array}{l}\text { Domingos } \\
\text { Rocha da } \\
\text { Silva Rios }\end{array}$ & $\begin{array}{l}\text { José Antonio } \\
\text { de Faria e sua } \\
\text { mulher D. } \\
\text { Anna Amélia } \\
\text { da C. Faria }\end{array}$ & $24 / 05 / 1880$ & $\begin{array}{l}\text { Confissão } \\
\text { dívida, } \\
\begin{array}{l}\text { obrigação } \\
\text { hipoteca }\end{array}\end{array}$ & $\begin{array}{l}\text { Valor não consta. } \\
\text { Garantia: outros bens }+7 \\
\text { escravos. }\end{array}$ & 12 & 11 \\
\hline 47 & $\begin{array}{l}\text { Francisco } \\
\text { José de Faria }\end{array}$ & $\begin{array}{l}\text { Gaudino Faria } \\
\text { da Motta e sua } \\
\text { mulher D. } \\
\text { Rosa Peniche } \\
\text { de Araujo } \\
\text { Faria }\end{array}$ & $10 / 07 / 1880$ & $\begin{array}{lr}\text { Confissão } & \text { de } \\
\text { dívida, } & \text { com } \\
\text { hipoteca } & \end{array}$ & $\begin{array}{l}\text { Valor: } 15: 000 \$ 000 \\
\text { Garantia: bens imóveis }+6 \\
\text { escravos (as). }\end{array}$ & 12 & 17 \\
\hline 48 & $\begin{array}{l}\text { Jeronimo } \\
\text { Francisco } \\
\text { Afonso } \\
\text { Durães }\end{array}$ & $\begin{array}{l}\text { Romão Lopes } \\
\text { e sua mulher } \\
\text { D. Felisberta } \\
\text { Rosa de } \\
\text { Amorim } \\
\text { Lopes }\end{array}$ & $22 / 11 / 1880$ & $\begin{array}{lr}\text { Escritura } & \text { de } \\
\text { dívida, } & \text { com } \\
\text { hipoteca } & \end{array}$ & $\begin{array}{l}\text { Valor: 14:000\$000. } \\
\text { Garantia: bens imóveis }+9 \\
\text { escravos. }\end{array}$ & 12 & $\begin{array}{l}22 \\
\text { verso }\end{array}$ \\
\hline
\end{tabular}




\begin{tabular}{|c|c|c|c|c|c|c|c|}
\hline 49 & $\begin{array}{l}\text { FIRMA: } \\
\text { Simões Faria } \\
\text { \& CIA }\end{array}$ & $\begin{array}{l}\text { Reginaldo } \\
\text { Gomes dos } \\
\text { Santos }\end{array}$ & $07 / 02 / 1881$ & $\begin{array}{ll}\text { Escritura } & \text { de } \\
\text { dívida, } & \\
\text { obrigação } & \text { e } \\
\text { hipoteca } & \end{array}$ & $\begin{array}{l}\text { Valor: } 4: 359 \$ 730 \text {. } \\
\text { Garantia: além de outros } \\
\text { bens }+2 \text { escravos. }\end{array}$ & 12 & 30 \\
\hline 51 & $\begin{array}{l}\text { José Alves } \\
\text { da Fonseca }\end{array}$ & $\begin{array}{l}\text { José Gomes da } \\
\text { Motta }\end{array}$ & $05 / 07 / 1881$ & $\begin{array}{ll}\text { Escritura } & \text { de } \\
\text { penhora } & \text { de } \\
\text { escravo } & \end{array}$ & $\begin{array}{l}\text { Valor: Não consta. } \\
\text { Garantia: } 6 \text { escravos }\end{array}$ & 12 & $43 \mathrm{v}$ \\
\hline 52 & $\begin{array}{l}\text { FIRMA: } \\
\text { Leonel } \\
\text { Joaquim de } \\
\text { Almeida } \\
\text { Fundão \& } \\
\text { CIA }\end{array}$ & 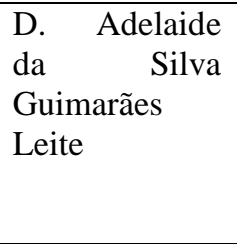 & $15 / 02 / 1882$ & $\begin{array}{ll}\begin{array}{l}\text { Escritura } \\
\text { dívida, }\end{array} & \text { de } \\
\text { obrigação } & \mathrm{e} \\
\text { hipoteca } & \end{array}$ & $\begin{array}{l}\text { Valor: } 5: 186 \$ 360 \text {. } \\
\text { Garantia: bens imóveis }+7 \\
\text { escravos. }\end{array}$ & 12 & $\begin{array}{l}56 \\
\text { verso }\end{array}$ \\
\hline 54 & $\begin{array}{l}\text { FIRMA: } \\
\text { Fundão } \\
\text { Junior } \quad \& \\
\text { CIA }\end{array}$ & $\begin{array}{l}\text { Virgilio José } \\
\text { da Motta e sua } \\
\text { mulher D. Rita } \\
\text { Silvares Motta }\end{array}$ & $30 / 03 / 1882$ & $\begin{array}{lr}\text { Confissão } & \text { de } \\
\text { dívida, } & \text { com } \\
\text { hipoteca } & \end{array}$ & $\begin{array}{l}\text { Valor: } 2: 800 \$ 000 \\
\text { Garantia: outros bens }+2 \\
\text { escravos. }\end{array}$ & 12 & 75 \\
\hline 55 & $\begin{array}{l}\text { Major } \\
\text { Antonio } \\
\text { Rodrigues } \\
\text { da Cunha }\end{array}$ & $\begin{array}{l}\text { D. Angélica } \\
\text { Faria Motta }\end{array}$ & $07 / 10 / 1880$ & $\begin{array}{lr}\text { Confissão } & \text { de } \\
\text { dívida, } & \text { com } \\
\text { hipoteca } & \end{array}$ & $\begin{array}{l}\text { Valor } 17: 412 \$ 000 \\
\text { Garantia: outros bens }+13 \\
\text { escravos (as). }\end{array}$ & 15 & 1 \\
\hline 57 & $\begin{array}{l}\text { Domingos } \\
\text { Rocha da } \\
\text { Silva Rios }\end{array}$ & $\begin{array}{l}\text { João José } \\
\text { Carvalho } \\
\text { Campos e sua } \\
\text { mulher D. } \\
\text { Constantina } \\
\begin{array}{l}\text { Maria de } \\
\text { Oliveira }\end{array}\end{array}$ & $19 / 01 / 1881$ & $\begin{array}{lr}\text { Confissão } & \text { de } \\
\text { dívida, } & \text { com } \\
\text { hipoteca } & \end{array}$ & $\begin{array}{l}\text { Valor: 3:082\$565. } \\
\text { Garantia: outros bens }+25 \\
\text { escravos (as). }\end{array}$ & 15 & $\begin{array}{l}16 \\
\text { verso }\end{array}$ \\
\hline 58 & $\begin{array}{l}\text { Major } \\
\text { Antonio } \\
\text { Rodrigues } \\
\text { da Cunha }\end{array}$ & $\begin{array}{l}\text { Rufino } \\
\text { Vicente de } \\
\text { Faria e sua } \\
\text { mulher D. Rita } \\
\text { Francisca de } \\
\text { Souza Faria }\end{array}$ & $05 / 02 / 1881$ & $\begin{array}{lr}\text { Confissão } & \text { de } \\
\text { dívida, } & \text { com } \\
\text { hipoteca } & \end{array}$ & $\begin{array}{l}\text { Valor: } 2: 500 \$ 000 \\
\text { Garantia: outros bens }+2 \\
\text { escravos (as). }\end{array}$ & 15 & 23 \\
\hline 59 & $\begin{array}{l}\text { Major } \\
\text { Antonio } \\
\text { Rodrigues } \\
\text { da Cunha }\end{array}$ & $\begin{array}{l}\text { José Antonio } \\
\text { de Faria e sua } \\
\text { mulher D. } \\
\text { Anna Amélia } \\
\text { da Conceição } \\
\text { Faria }\end{array}$ & $08 / 02 / 1881$ & $\begin{array}{l}\text { Confissão de } \\
\text { dívida }\end{array}$ & $\begin{array}{l}\text { Valor: 1:960\$000. } \\
\text { Garantia: bens imóveis }+2 \\
\text { escravos. }\end{array}$ & 15 & 24 \\
\hline 60 & $\begin{array}{l}\text { Capitão } \\
\text { Manoel } \\
\text { Lopes de } \\
\text { Azevedo }\end{array}$ & $\begin{array}{l}\text { Domingos } \\
\text { Rocha } \\
\text { Monjardim }\end{array}$ & $21 / 02 / 1881$ & $\begin{array}{lr}\text { Escritura } & \text { de } \\
\text { débito, } & \text { sob } \\
\text { penhora } & \end{array}$ & $\begin{array}{l}\text { Valor: 2:600\$000. } \\
\text { Garantia: } 2 \text { escravos. }\end{array}$ & 15 & 27 \\
\hline 61 & $\begin{array}{l}\text { Domingos } \\
\text { Rocha da } \\
\text { Silva Rios }\end{array}$ & $\begin{array}{l}\text { Joaquim } \\
\text { Francisco da } \\
\text { Silva e sua } \\
\text { mulher } \quad \text { D. } \\
\text { Leocádia } \\
\text { Francisca dos } \\
\text { Santos Sila } \\
\end{array}$ & $28 / 03 / 1881$ & $\begin{array}{lr}\text { Escritura } & \text { de } \\
\text { Confissão } & \text { de } \\
\text { Débito, } & \\
\text { Obrigação } & \text { e } \\
\text { Hipoteca } & \end{array}$ & $\begin{array}{l}\text { Valor: 4:780\$613. } \\
\text { Garantia: Outros bens }+6 \\
\text { escravos. }\end{array}$ & 15 & 33 \\
\hline 62 & $\begin{array}{l}\text { Domingos } \\
\text { Rocha da } \\
\text { Silva Rios }\end{array}$ & $\begin{array}{l}\text { Luiz Pereira } \\
\text { de } \\
\text { Vasconcellos } \\
\text { e sua mulher } \\
\text { D. Constança } \\
\text { Maria do } \\
\text { Rosário } \\
\text { Vasconcellos }\end{array}$ & $09 / 05 / 1881$ & $\begin{array}{lr}\text { Escritura } & \text { de } \\
\text { dívida, } & \text { sob } \\
\text { penhor } & \end{array}$ & $\begin{array}{l}\text { Valor: } 920 \$ 720 . \\
\text { Garantia: escravo Aprígio. }\end{array}$ & 15 & $\begin{array}{l}38 \\
\text { verso }\end{array}$ \\
\hline
\end{tabular}




\begin{tabular}{|c|c|c|c|c|c|c|c|}
\hline 63 & $\begin{array}{l}\text { Vicente } \\
\text { Lopes de } \\
\text { Oliveira }\end{array}$ & $\begin{array}{l}\text { Luiz Pereira } \\
\text { de } \\
\text { Vasconcellos } \\
\text { e sua mulher } \\
\text { D. Constança } \\
\text { Maria do } \\
\text { Rosário } \\
\text { Vasconcellos }\end{array}$ & $09 / 05 / 1881$ & $\begin{array}{lr}\text { Confissão } & \text { de } \\
\text { dívida } & \text { com } \\
\text { hipoteca } & \\
\end{array}$ & $\begin{array}{l}\text { Valor: } 2: 912 \$ 890 . \\
\text { Garantia: envolve também } \\
\text { o escravo José }\end{array}$ & 15 & $40 \mathrm{v}$ \\
\hline 64 & $\begin{array}{l}\text { Domingos } \\
\text { Rocha da } \\
\text { Silva Rios }\end{array}$ & $\begin{array}{lr}\text { João de } & \text { Jesus } \\
\text { Silvares e sua } \\
\text { mulher Rufina } \\
\text { Pinto r das } \\
\text { Virgens }\end{array}$ & $06 / 06 / 1881$ & $\begin{array}{lr}\text { Confissão } & \text { de } \\
\text { dívida } & \text { com } \\
\text { hipoteca } & \end{array}$ & $\begin{array}{l}\text { Valor: 5:000\$000. } \\
\text { Garantia: envolve também } \\
+12 \text { escravos }\end{array}$ & 15 & 50 \\
\hline 65 & $\begin{array}{l}\text { Domingos } \\
\text { Rocha da } \\
\text { Silva Rios }\end{array}$ & $\begin{array}{l}\text { Manoel } \\
\text { Ribeiro de } \\
\text { Jesus Silvares } \\
\text { Sobrinho e sua } \\
\text { mulher }\end{array}$ & $07 / 06 / 1881$ & $\begin{array}{lr}\text { Confissão } & \text { de } \\
\text { dívida } & \text { com } \\
\text { hipoteca } & \\
\end{array}$ & $\begin{array}{l}\text { Valor: 7:000\$000. } \\
\text { Garantia: envolve também } \\
+7 \text { escravos }\end{array}$ & 15 & 54 \\
\hline 66 & $\begin{array}{l}\text { Major } \\
\text { Antonio } \\
\text { Rodrigues } \\
\text { da Cunha } \\
\end{array}$ & $\begin{array}{l}\text { Manoel Alves } \\
\text { de Magalhães }\end{array}$ & $07 / 10 / 1881$ & $\begin{array}{lr}\text { Confissão } & \text { de } \\
\text { dívida } & \text { sob } \\
\text { penhor } & \end{array}$ & $\begin{array}{l}\text { Valor: 1:175\$000. } \\
\text { Garantia: escravo Livinio }\end{array}$ & 15 & $71 \mathrm{v}$ \\
\hline 67 & $\begin{array}{l}\text { Domingos } \\
\text { Rocha da } \\
\text { Silva Rios }\end{array}$ & $\begin{array}{l}\text { Francisco } \\
\text { Coutinho de } \\
\text { Almeida }\end{array}$ & $29 / 10 / 1881$ & $\begin{array}{lr}\text { Confissão } & \text { de } \\
\text { dívida } & \text { sob } \\
\text { penhor } & \\
\end{array}$ & $\begin{array}{l}\text { Valor: 1:500\$000. } \\
\text { Garantia: } 2 \text { escravos }\end{array}$ & 15 & 76 \\
\hline 68 & $\begin{array}{l}\text { FIRMA } \\
\text { Leonel } \\
\text { Joaquim de } \\
\text { Almeida } \\
\text { Fundão \& } \\
\text { Cia }\end{array}$ & $\begin{array}{l}\text { José Pinheiro } \\
\text { da Silva }\end{array}$ & 17/01/1882 & $\begin{array}{l}\text { Confissão } \\
\text { dívida, }\end{array}$ & $\begin{array}{l}\text { Valor: } 8: 115 \$ 000 \\
\text { Garantia: outros bens }+3 \\
\text { escravos }\end{array}$ & 15 & 88 \\
\hline 70 & $\begin{array}{l}\text { FIRMA } \\
\text { Leonel } \\
\text { Joaquim de } \\
\text { Almeida } \\
\text { Fundão \& } \\
\text { Cia } \\
\end{array}$ & $\begin{array}{ll}\text { Capitão } & \\
\text { Adeodato } & \\
\text { Antonio dos } \\
\text { Santos e sua } \\
\text { mulher }\end{array}$ & $27 / 02 / 1885$ & $\begin{array}{lr}\text { Escritura } & \text { de } \\
\text { Confissão } & \text { de } \\
\text { Dívida } & \text { com } \\
\text { hipoteca } & \end{array}$ & $\begin{array}{l}\text { Valor: } 7: 360 \$ 320 \text {. } \\
\text { Garantia: bens imóveis/ } \\
\text { semoventes }+8 \text { escravos }\end{array}$ & 18 & 43 \\
\hline 71 & $\begin{array}{l}\text { Tenente José } \\
\text { dos Santos } \\
\text { Neves e } \\
\text { outros }\end{array}$ & $\begin{array}{l}\text { Olimpio Leite } \\
\text { de Amorim }\end{array}$ & $06 / 06 / 1885$ & $\begin{array}{lr}\text { Confissão } & \text { de } \\
\text { dívida } & \text { com } \\
\text { hipoteca } & \\
\end{array}$ & $\begin{array}{l}\text { Valor: } 13: 701 \$ 910 . \\
\text { Garantia: outros bens }+10 \\
\text { escravos e } 5 \text { ingênuos }\end{array}$ & 18 & 51 \\
\hline
\end{tabular}

OBS:

1. $\mathrm{O} \mathrm{n}^{\circ}$ constante na primeira coluna desta tabela corresponde ao $\mathrm{n}^{\circ}$ desses documentos na Planilha básica dos negócios avulsos com escravos.

2. Verificar o caso do item $n^{\circ} 37$, pois o valor da hipoteca é baixo em relação ao montante dos bens sob garantia. 
QUADRO 2: Outros tipos de negócios comerciais envolvendo escravos em São Mateus (1863 - 1888).

\begin{tabular}{|c|c|c|c|c|c|c|c|}
\hline $\mathbf{N}^{\mathbf{o}}$ & TIPO DOC & ESCRAVO (a) & DONO ESCRAVO & PESSOA REF. & DATA & $\mathbf{L}$ & $\mathbf{F}$ \\
\hline 01 & $\begin{array}{l}\text { Escritura de } \\
\text { doação } \\
\text { causa-mortes }\end{array}$ & $\begin{array}{l}\text { HENRIQUETA - (28 anos }) \\
\text { "... e do moleque seu filho de } \\
\text { nome Antonio, de } 7 \text { anos." }\end{array}$ & $\begin{array}{l}\text { Inocência } \quad \text { Durans } \\
\text { (Doadora) }\end{array}$ & $\begin{array}{l}\text { José Francisco de } \\
\text { Medeiros (Donatário) }\end{array}$ & $06 / 10 / 1863$ & 01 & 34 \\
\hline 02 & Doação & $\begin{array}{l}\text { BENEDITO - (“ } \ldots \text { crioulo, } \\
\text { preso na Cadeia desta cidade, } \\
\text { sentenciado pelo Jury.”) }\end{array}$ & $\begin{array}{l}\text { Manoel José } \\
\text { Rodrigues de Oliveira } \\
\text { (Doador) }\end{array}$ & $\begin{array}{l}\text { João Pereira da Silva } \\
\text { Sarmento (Donatário) }\end{array}$ & $11 / 06 / 1864$ & 01 & 49 \\
\hline 03 & Doação & $\begin{array}{l}\text { AVELINA - ("de } 11 \text { anos de } \\
\text { idade, de cor parda, natural } \\
\text { desta cidade, costureira") }\end{array}$ & $\begin{array}{l}\text { Manoel José } \\
\text { Rodrigues de Oliveira } \\
\text { (Doador) }\end{array}$ & $\begin{array}{ll}\text { Deolinda Maria de } & \text { de } \\
\text { Oliveira (Donatária) } & \end{array}$ & $11 / 08 / 1866$ & 01 & 113 \\
\hline 04 & 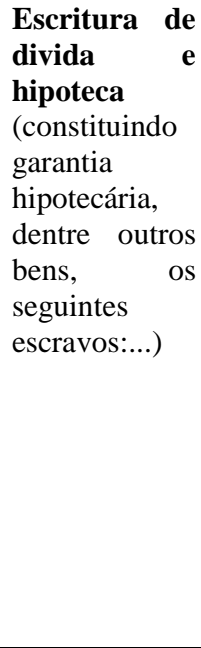 & $\begin{array}{l}\text { ROSA (crioula, maior de } 40 \\
\text { anos, pelo valor de } \\
1: 300 \$ 000) \text {; } \\
\text { BALDOINA (maior de } 40 \\
\text { anos, solteira, de cor cabra, no } \\
\text { valor de 1:300\$000); } \\
\text { JOSEFA (maior de } 25 \text { anos, } \\
\text { de Nação, casada, cor cabra, } \\
\text { com 1 filho de nome } \\
\text { Felismino, no valor de } \\
1: 200 \$ 000) \text { JOÃO (de } \\
\text { Nação, casado, maior de } 30 \\
\text { anos, no valor de } 600 \$ 000 \\
\text { (?); ESPERANÇA (de Nação, } \\
30 \text { anos, casada, preta, no } \\
\text { valor de } 1: 000 \$ 000, \text { com uma } \\
\text { cria de nome João, c/ } 6 \text { meses } \\
\text { de idade) }\end{array}$ & $\begin{array}{l}\text { D. Anna Maria da } \\
\text { Conceição } \\
\text { (na qualidade de } \\
\text { tutora de seus filhos } \\
\text { menores Itelvina, } \\
\text { José, Leocádia e } \\
\text { Francelino) }\end{array}$ & $\begin{array}{l}\text { * A Hipoteca tem por } \\
\text { finalidade a segurança e } \\
\text { garantia das legitimas } \\
\text { de seus aludidos filhos, } \\
\text { no inventário de seu pai } \\
\text { Ignácio Antonio } \\
\text { Cardoso. }\end{array}$ & $01 / 10 / 1866$ & 01 & 123 \\
\hline 05 & 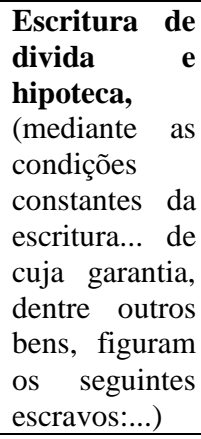 & $\begin{array}{l}\text { VICENCIA (crioula, com } 30 \\
\text { anos, preta, profissão de roça, } \\
\text { solteira); } \text { BENEDITA } \\
\text { (crioula, com } 30 \text { anos, } \\
\text { profissão de roça, solteira, } \\
\text { com } 2 \text { crias: Victoria, com } 2 \\
\text { anos de idade e outra ainda } \\
\text { por batizar, com } 5 \text { anos de } \\
\text { idade) }\end{array}$ & $\begin{array}{l}\text { Simplicio Alfonço de } \\
\text { Barcellos e sua } \\
\text { mulher Maria Ribeiro } \\
\text { da Conceição } \\
\text { (DEVEDORES) }\end{array}$ & $\begin{array}{l}\text { Reginaldo Gomes dos } \\
\text { Santos (CREDOR) }\end{array}$ & $07 / 12 / 1866$ & 01 & 136 \\
\hline 06 & $\begin{array}{l}\text { Permuta de } \\
\text { Escravos }\end{array}$ & 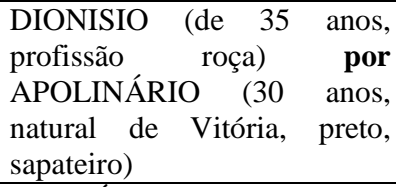 & $\begin{array}{lr}\text { João } & \text { Gomes } \\
\text { Gonçalves } & \text { Michas } \\
\text { (PERMUTANTE) }\end{array}$ & $\begin{array}{l}\text { Manoel Francisco da } \\
\text { Motta } \\
\text { (PERMUTANTE) }\end{array}$ & $22 / 06 / 1867$ & 02 & 28 \\
\hline 07 & $\begin{array}{l}\text { Distrato de } \\
\text { compra }\end{array}$ & LEOCÁDIA & $\begin{array}{l}\text { Constantino Gomes } \\
\text { da Cunha (Tenente) }\end{array}$ & $\begin{array}{lll}\text { Manoel } & \text { Ferreira } & \text { de } \\
\text { Almeida } & & \\
\end{array}$ & $18 / 01 / 1868$ & 02 & 100 \\
\hline $\mathbf{N}^{\mathbf{o}}$ & TIPO DOC & ESCRAVO (a) & DONO ESCRAVO & PESSOA REF. & DATA & $\mathbf{L}$ & $\mathbf{F}$ \\
\hline 08 & $\begin{array}{l}\text { Contrato } \\
\text { (firmado, sob } \\
\text { condições, } \\
\text { entre } \\
\text { Francisco José } \\
\text { da Silva, sua } \\
\text { mulher e seus } \\
\text { filhos, } \\
\text { envolvendo } \\
\text { bens imóveis } \\
\text { e os seguintes } \\
\text { escravos:...) }\end{array}$ & $\begin{array}{l}\text { MARCOLINO (crioulo, de } 24 \\
\text { anos); } \\
\text { MARTHA (de Nação) e } \\
\text { SABINO (de Nação). }\end{array}$ & $?$ & $?$ & $26 / 04 / 1870$ & 02 & 273 \\
\hline 09 & $\begin{array}{l}\text { Escritura de } \\
\text { contrato } \\
\text { (entre partes }\end{array}$ & VALLERIANNA & $?$ & $?$ & $21 / 05 / 1870$ & 02 & 275 \\
\hline
\end{tabular}




\begin{tabular}{|c|c|c|c|c|c|c|c|}
\hline & $\begin{array}{l}\text { Antonio Leite } \\
\text { de Barcellos e } \\
\text { Manoel } \\
\text { Ignácio das } \\
\text { Chagas - } \\
\text { Escritura } \\
\text { lavrada em } \\
\text { face da ação } \\
\text { proposta por } \\
\text { Antônio José } \\
\text { de Oliveira } \\
\text { Pinha, contra } \\
\text { Antonio Leite } \\
\text { de Barcellos, } \\
\text { relacionada } \\
\text { com a escrava } \\
\text { de nome } \\
\text { Vallerianna } \\
\text { que havia sido } \\
\text { arrematada } \\
\text { em praça do } \\
\text { Juízo } \\
\text { Municipal } \\
\text { desta cidade, } \\
\text { com recurso } \\
\text { para o } \\
\text { Supremo } \\
\text { Tribunal da } \\
\text { Relação...) }\end{array}$ & & & & & & \\
\hline 10 & $\begin{array}{ll}\text { Troca } & \text { de } \\
\text { escravos } & \\
\end{array}$ & DEMETRIO por JOAQUIM & José Antônio Aguirre & $\begin{array}{l}\text { Manoel Cosme da } \\
\text { Motta }\end{array}$ & $08 / 05 / 1871$ & 02 & 323 \\
\hline 11 & $\begin{array}{lr}\text { Recibo } & \\
\text { (no valor } & \text { de } \\
10 \$ 000, & \text { a } \\
\text { titulo } & \text { de } \\
\text { aluguel } & \text { da } \\
\text { escrava...) } & \\
\end{array}$ & LUCINDA (cor parda) & $\begin{array}{l}\text { Manoel Ignácio das } \\
\text { Chagas }\end{array}$ & $\begin{array}{l}\text { Joaquim Barbosa de } \\
\text { Souza }\end{array}$ & $18 / 05 / 1872$ & 02 & 365 \\
\hline 12 & $\begin{array}{l}\text { Contrato } \\
\text { (entre mãe e } \\
\text { filho, onde a } \\
\text { mãe entrega } \\
\text { ao mesmo, } \\
\text { para } \\
\text { administrá-la, } \\
\text { a fazenda } \\
\text { denominada } \\
\text { "Antonio } \\
\text { Gomes do } \\
\text { Norte", com } \\
\text { todos escravos } \\
\text { e bens da } \\
\text { lavoura) }\end{array}$ & $\begin{array}{l}\text { Todos os escravos (não } \\
\text { constam os nomes) }\end{array}$ & $\begin{array}{l}\text { Josepha Francisca do } \\
\text { Sacramento } \\
\text { (MÃE) }\end{array}$ & $\begin{array}{l}\text { Domingos } \quad \text { Rocha } \\
\text { Monjardim (FILHO) }\end{array}$ & $15 / 03 / 1873$ & 02 & 394 \\
\hline 13 & $\begin{array}{l}\text { Permuta de } \\
\text { escravas... }\end{array}$ & $\begin{array}{l}\text { ADELINA (e sua filha de } \\
\text { nome Ambrosina) pela } \\
\text { escrava de nome OLIMPIA } \\
\text { (pelo valor de } 1.500 \$ 000 \text { e } \\
300 \$ 000 \text { ?) }\end{array}$ & $\begin{array}{l}\text { Ernesto Cardoso de } \\
\text { Oliveira Bastos } \\
\text { (PERMUTANTE) }\end{array}$ & $\begin{array}{l}\text { Rosa Gomes de } \\
\text { Araújo } \\
\text { (PERMUTANTE) }\end{array}$ & $11 / 09 / 1872$ & 04 & 126 \\
\hline $\mathbf{N}^{\mathbf{o}}$ & TIPO DOC & ESCRAVO (a) & DONO ESCRAVO & PESSOA REF. & DATA & $\mathbf{L}$ & $\mathbf{F}$ \\
\hline 14 & $\begin{array}{lr}\text { Contrato } \\
\text { (de } & \text { sociedade } \\
\text { de } & \text { lavoura } \\
\text { entre } & \text { sogra e } \\
\end{array}$ & $\begin{array}{l}\text { Todos os escravos (não } \\
\text { constam os nomes) }\end{array}$ & $\begin{array}{l}\text { Rosa Gomes de Araújo } \\
\text { (SOGRA) }\end{array}$ & $\begin{array}{l}\text { Ernesto Cardoso de } \\
\text { Oliveira Bastos } \\
(\text { GENRO) }\end{array}$ & $04 / 06 / 1873$ & 06 & 6 \\
\hline
\end{tabular}




\begin{tabular}{|c|c|c|c|c|c|c|c|}
\hline & $\begin{array}{l}\text { genro, ao qual } \\
\text { é entregue a } \\
\text { Fazenda } \\
\text { denominada } \\
\text { "Bom } \\
\text { Sucesso", ao } \\
\text { sul do Rio } \\
\text { desta cidade, } \\
\text { em } \\
\text { sociedade, } \\
\text { com todo o } \\
\text { produto da } \\
\text { mesma, } \\
\text { fazendo } \\
\text { referência, } \\
\text { inclusive, aos } \\
\text { ESCRAVOS) }\end{array}$ & & & & & & \\
\hline 15 & $\begin{array}{ll}\text { Escritura } & \text { de } \\
\text { penhor } & \text { da } \\
\text { escrava... } & \\
\end{array}$ & $\begin{array}{l}\text { SEVERIANA } \\
\text { (qualificada na escritura, pela } \\
\text { quantia de } 700 \$ 000 \text { ) }\end{array}$ & $\begin{array}{l}\text { Francisco Coutinho } \\
\text { d'Essa } \\
\text { (OUTORGANTE) }\end{array}$ & $\begin{array}{ll}\begin{array}{l}\text { Sebastião } \\
\text { Barbosa }\end{array} & \text { José } \\
\text { (OUTORGADO) } & \\
\end{array}$ & $17 / 09 / 1874$ & 06 & 30 \\
\hline 16 & 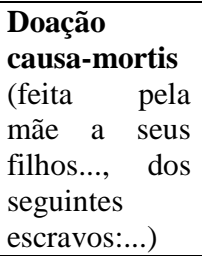 & $\begin{array}{l}\text { ADÃO (preto, matriculado } \\
\text { neste município..., } \\
\text { LEOPOLDINO e (preto, } \\
\text { matricula idem, idem...). } \\
\text { Valor atribuído }=2.000 \$ 000 .\end{array}$ & $\begin{array}{l}\text { Severina Rodrigues de } \\
\text { Sousa (MÃE) }\end{array}$ & $\begin{array}{l}\text { Filhos (sem nomes } \\
\text { destacados) }\end{array}$ & $28 / 12 / 1876$ & 06 & 115 \\
\hline 17 & $\begin{array}{l}\text { Hipotecados.. } \\
\text { (juntamente } \\
\text { com bens } \\
\text { imóveis, os } \\
\text { seguintes } \\
\text { escravos:...) }\end{array}$ & $\begin{array}{l}\text { IZIDIO } \\
\text { IZABEL } \\
\text { IGNACIO } \\
\text { HONORINA }\end{array}$ & $\begin{array}{l}\text { Anna Maria de Oliveira } \\
\text { Chagas (e herdeiros do } \\
\text { finado João José das } \\
\text { Chagas) }\end{array}$ & $\begin{array}{l}\text { Olívio Bento de Jesus } \\
\text { Silvares }\end{array}$ & 07/06/1877 & 06 & 126 \\
\hline 18 & $\begin{array}{l}\text { Escritura de } \\
\text { hipoteca } \\
\text { (cujo crédito, } \\
\text { no valor de } \\
800 \$ 000, \\
\text { além de estar } \\
\text { garantido com } \\
\text { imóvel, } \\
\text { constitui parte } \\
\text { da garantia, } \\
\text { também o } \\
\text { escravo de } \\
\text { nome...) }\end{array}$ & FORTUNATO (preto) & $\begin{array}{l}\text { Olívio Bento de Jesus } \\
\text { Silvares } \\
\text { (OUTORGANTE } \\
\text { DEVEDOR) }\end{array}$ & $\begin{array}{l}\text { Lourenço Bernardo } \\
\text { Vieira } \\
\text { (OUTORGADO } \\
\text { CREDOR) }\end{array}$ & $14 / 06 / 1877$ & 06 & 129 \\
\hline 19 & $\begin{array}{l}\begin{array}{l}\text { Escritura de } \\
\text { dação }\end{array} \\
\text { insolutum } \\
\text { (na qual o } \\
\text { escravo } \\
\text { referido foi } \\
\text { entregue ao } \\
\text { credor } \\
\text { hipotecário, } \\
\text { como } \\
\text { pagamento da } \\
\text { respectiva } \\
\text { dívida) } \\
\end{array}$ & FORTUNATO & $\begin{array}{l}\text { Olívio Bento de Jesus } \\
\text { Silvares (DEVEDOR) }\end{array}$ & $\begin{array}{ll}\text { Lourenço } & \text { Bernardo } \\
\text { Vieira (CREDOR) }\end{array}$ & 09/07/1877 & 06 & $\begin{array}{l}131 \\
\mathrm{v}\end{array}$ \\
\hline 20 & $\begin{array}{l}\text { Escritura de } \\
\text { hipoteca } \\
\text { (cuja garantia } \\
\text { é um imóvel, } \\
\text { além dos } \\
\text { seguintes } \\
\end{array}$ & $\begin{array}{l}\text { JOSEPHA (preta) } \\
\text { BENVINDO (africano preto) } \\
\text { MARCOS (preto africano) } \\
\text { BENEDICTO (preto africano) }\end{array}$ & $\begin{array}{ll}\text { Matheus } & \text { Cantien } \\
\text { (DEVEDOR) } & \end{array}$ & $\begin{array}{l}\text { Antonio José de } \\
\text { Oliveira (CREDOR) }\end{array}$ & $04 / 01 / 1875$ & 07 & 17 \\
\hline
\end{tabular}




\begin{tabular}{|c|c|c|c|c|c|c|c|}
\hline & escravos:...) & & & & & & \\
\hline 21 & $\begin{array}{l}\text { Empréstimo, } \\
\text { sob penhora } \\
\text { (cuja garantia } \\
\text { foi oferecida, } \\
\text { com os } \\
\text { escravos...) }\end{array}$ & $\begin{array}{l}\text { JOANNA (cor cabra) e } \\
\text { CELESTINA (cor cabra, filha } \\
\text { de Joanna) - Ambas avaliadas } \\
\text { pelo valor de } 1.200 \$ 000 .\end{array}$ & $\begin{array}{ll}\text { Miguel } & \text { Ferreira } \\
\text { Custódio } & \text { Barbosa } \\
\text { (DEVEDOR) } & \end{array}$ & $\begin{array}{l}\text { A Firma Fonseca Rios } \\
\& \quad \text { Companhia } \\
(\text { CREDORES })\end{array}$ & $11 / 02 / 1875$ & 07 & 27 \\
\hline $\mathbf{N}^{\mathbf{o}}$ & TIPO DOC & ESCRAVO (a) & DONO ESCRAVO & PESSOA REF. & DATA & $\mathbf{L}$ & $\mathbf{F}$ \\
\hline 22 & $\begin{array}{l}\text { Doação } \\
\text { causa-mortis } \\
\text { (da mãe às } \\
\text { suas filhas...) }\end{array}$ & $\begin{array}{l}\text { ELEUTERIA, com o valor de } \\
300 \$ 000\end{array}$ & $\begin{array}{l}\text { D. Maria da Conceição } \\
\text { (mãe) } \\
\text { (DOADORA) }\end{array}$ & $\begin{array}{l}\text { Anna Maria da } \\
\text { Victoria e Manoela } \\
\text { Leopoldina } \\
\text { Conceição (filhas) } \\
\text { (DONATÁRIAS) } \\
\end{array}$ & $08 / 03 / 1875$ & 07 & $36 \mathrm{v}$ \\
\hline 23 & $\begin{array}{l}\text { Doação } \\
\text { causa-mortis } \\
\text { (doação da } \\
\text { mãe ao seu } \\
\text { filho, da sua } \\
\text { terça parte do } \\
\text { escravo...) }\end{array}$ & CRISTINO (crioulo) & $\begin{array}{l}\text { D. Innocência Durães } \\
\text { (mãe) } \\
\text { (DOADORA) }\end{array}$ & $\begin{array}{lr}\text { Jerônimo } & \text { Francisco } \\
\text { Affonso } & \text { Durães } \\
\text { (filho) } & \\
\text { (DONATÁRIO) }\end{array}$ & $10 / 09 / 1875$ & 07 & 90 \\
\hline 24 & 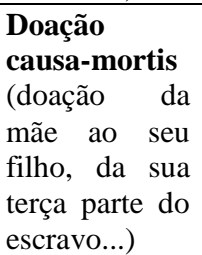 & ANTONIO (crioulo-preto) & $\begin{array}{l}\text { D. Innocência Durães } \\
\text { (mãe) } \\
\text { (DOADORA) }\end{array}$ & $\begin{array}{l}\text { José Francisco } \\
\text { Medeiros (filho) } \\
\text { (DONATÁRIO) }\end{array}$ & $10 / 09 / 1875$ & 07 & 91 \\
\hline 25 & $\begin{array}{l}\text { Escritura de } \\
\text { débito, sob } \\
\text { penhor } \\
\text { (cuja garantia } \\
\text { são os } \\
\text { escravos...) }\end{array}$ & $\begin{array}{l}\text { DESIDERIO (preto) } \\
\text { LUCINDO (preto) }\end{array}$ & $\begin{array}{l}\text { Bernardino } \\
\text { Pereira } \\
\text { (DEVEDOR) }\end{array}$ & $\begin{array}{l}\text { A Firma Fonseca, } \\
\text { Rios \& Cia. } \\
\text { (CREDORA) }\end{array}$ & $08 / 01 / 1876$ & 07 & 136 \\
\hline 26 & 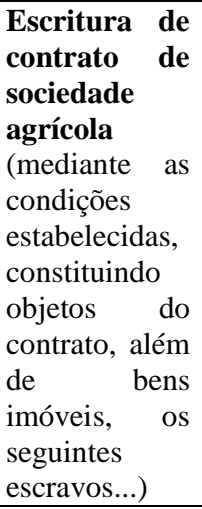 & $\begin{array}{l}\text { REGOSINO (crioulo) } \\
\text { UMBELINA (crioula) } \\
\text { JOAQUIM (crioulo) } \\
\text { FELIPPE (crioulo) } \\
\text { MANOEL } \\
\text { TIBURCIO e } \\
\text { ANTONIO. }\end{array}$ & $\begin{array}{l}\text { "Na sociedade em } \\
\text { apreço, são partes: } \\
\text { Manoel Pedro Machado } \\
\text { Rangel e sua mulher } \\
\text { Rosa Francisca de } \\
\text { Medeiros e José Pedro } \\
\text { Rangel" }\end{array}$ & $?$ & $25 / 06 / 1877$ & 07 & 331 \\
\hline 27 & $\begin{array}{l}\text { Permuta de } \\
\text { escravos }\end{array}$ & $\begin{array}{l}\text { IZIDORO (no valor de } \\
\text { 1:500\$000) por REGOSINO } \\
\text { (no mesmo valor) }\end{array}$ & $\begin{array}{l}\text { Tenente José dos Santos } \\
\text { Neves } \\
\text { (PERMUTANTE) }\end{array}$ & $\begin{array}{l}\text { Bellarmino Pinto } \\
\text { Netto } \\
\text { (PERMUTANTE) }\end{array}$ & $15 / 04 / 1878$ & 07 & 379 \\
\hline 28 & $\begin{array}{l}\text { Empréstimo, } \\
\text { débito e } \\
\text { obrigação, } \\
\text { sob penhor } \\
\text { (no valor de } \\
2: 679 \$ 000, . . \\
\text { constituindo, } \\
\text { dentre outros } \\
\text { bens, objetos } \\
\text { da garantia , } \\
\text { os seguintes } \\
\text { escravos...) }\end{array}$ & $\begin{array}{l}\text { FRANCISCO } \\
\text { ANTONIO e } \\
\text { GERVASIO }\end{array}$ & $\begin{array}{l}\text { João de Jesus } \\
\text { Junior e sua mules } \\
\text { Claudiana Maria da } \\
\text { Silva } \\
\text { (DEVEDORES) }\end{array}$ & $\begin{array}{l}\text { Domingos Rocha da } \\
\text { Silva Rios } \\
\text { (CREDOR) }\end{array}$ & $26 / 04 / 1878$ & 07 & 383 \\
\hline 29 & $\begin{array}{l}\text { Escritura de } \\
\text { dação }\end{array}$ & $\begin{array}{l}\text { MARIANNA parda, } \\
\text { matriculada na Província do }\end{array}$ & $\begin{array}{ll}\text { José Rodrigues } & \text { de } \\
\text { Oliveira Netto } & \end{array}$ & $\begin{array}{lrr}\text { A } & \text { Firma } & \text { Joaquim } \\
\text { Lopes \& } & \text { Irmão }\end{array}$ & $26 / 01 / 1878$ & 10 & 3 \\
\hline
\end{tabular}




\begin{tabular}{|c|c|c|c|c|c|c|c|}
\hline & $\begin{array}{ll}\begin{array}{l}\text { insolutum } \\
\text { (valor }\end{array} \text { da } \\
\text { dívida: } \\
387 \$ 000 \text { ) }\end{array}$ & $\begin{array}{l}\text { Ceará, averbada no Termo de } \\
\text { Villa da Barra) }\end{array}$ & (DEVEDOR) & (CREDORES) & & & \\
\hline 30 & $\begin{array}{l}\text { Escritura de } \\
\text { transferência } \\
\text { dos serviços } \\
\text { da liberta } \\
\text { Genoveva } \\
(? ? ?) \text { forma } \\
\text { (na na } \\
\text { prevista nat...) } \\
\text { escritura }\end{array}$ & $\begin{array}{l}\text { GENOVEVA } \\
\text { (liberta) }\end{array}$ & $\begin{array}{l}\text { Francisco José Marques } \\
\text { de Abreu } \\
\text { (TRANSMITENTE) }\end{array}$ & $\begin{array}{l}\text { Domingos Rocha da } \\
\text { Silva Rios } \\
\text { (ADQUIRENTE) }\end{array}$ & $27 / 07 / 1878$ & 10 & 36 \\
\hline $\mathbf{N}^{\mathbf{o}}$ & TIPO DOC & ESCRAVO (a) & DONO ESCRAVO & PESSOA REF. & DATA & $\mathbf{L}$ & $\mathbf{F}$ \\
\hline 31 & $\begin{array}{ll}\begin{array}{l}\text { Escritura } \\
\text { garantia }\end{array} & \begin{array}{l}\text { do } \\
\text { valor }\end{array} \text { de } \\
1: 500 \$ 000, \\
\text { mediante } \\
\text { penhor do } \\
\text { escravo... }\end{array}$ & TORQUATO (pardo) & $\begin{array}{l}\text { Manoel Antonio do } \\
\text { Couto e sua mulher } \\
\text { (DEVEDORES) }\end{array}$ & $\begin{array}{l}\text { A Firma Leonel } \\
\text { Joaquim de Almeida } \\
\text { Fundão \& Cia. } \\
\text { (CREDORES) }\end{array}$ & $10 / 08 / 1878$ & 10 & $41 \mathrm{v}$ \\
\hline 32 & 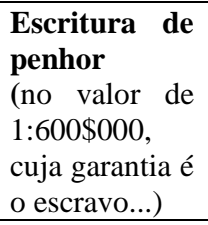 & TORQUATO (pardo) & $\begin{array}{l}\text { Manoel Antonio do } \\
\text { Couto e sua mulher } \\
\text { (DEVEDORES) }\end{array}$ & $\begin{array}{lr}\text { (CREDORES) } & \\
\text { Não consta } & \text { (mas } \\
\text { devem } \quad \text { ser } & \text { os } \\
\text { mesmos acima) } & \end{array}$ & $11 / 09 / 1878$ & 10 & 53 \\
\hline 33 & $\begin{array}{l}\text { Escritura de } \\
\text { Hipoteca } \\
\text { (pelo valor de } \\
5: 281 \$ 505 \\
\text { cuja garantia, } \\
\text { além de bens } \\
\text { imóveis, } \\
\text { envolve os } \\
\text { seguintes } \\
\text { escravos...) }\end{array}$ & 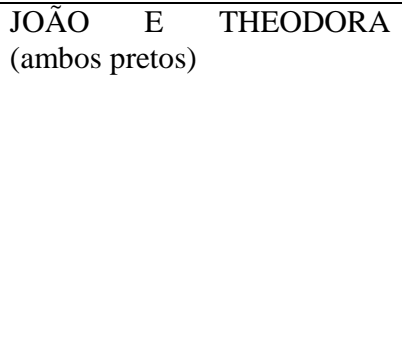 & $\begin{array}{l}\text { D. Anna Maria de } \\
\text { Oliveira Chagas } \\
\text { (DEVEDORA) }\end{array}$ & $\begin{array}{l}\text { A Firma } r \text { Leonel } \\
\text { Joaquim de Almeida } \\
\text { Fundão \& Cia. }\end{array}$ & $09 / 10 / 1878$ & 10 & $55 \mathrm{v}$ \\
\hline 34 & 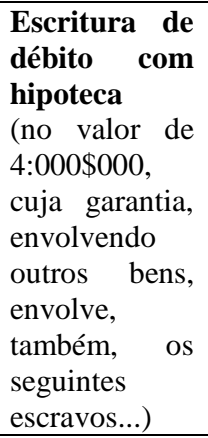 & $\begin{array}{l}\text { REGOSINO, MANOEL, } \\
\text { TIBURCIO, JOAQUINA, } \\
\text { FELLIPPINA, URSULINA, } \\
\text { BENEDICTA, ANTONIO e } \\
\text { GUILHERMINA }\end{array}$ & $\begin{array}{l}\text { Manoel Pedro Machado } \\
\text { Rangel e sua mulher } \\
\text { (DEVEDORES) }\end{array}$ & $\begin{array}{l}\text { Coronel Matheus } \\
\text { Antonio dos Santos } \\
\text { (CREDOR) }\end{array}$ & $12 / 10 / 1878$ & 11 & 31 \\
\hline 35 & $\begin{array}{l}\begin{array}{l}\text { Escritura de } \\
\text { dívida, com } \\
\text { hipoteca } \\
\text { (no valor de } \\
611 \$ 560 \text {, cuja } \\
\text { garantia, além } \\
\text { de outros } \\
\text { bens, é } \\
\text { constituída, } \\
\text { também, pela } \\
\text { escrava de } \\
\text { nome...) }\end{array} \\
\end{array}$ & $\begin{array}{l}\text { FILISDORIA } \\
\text { matriculada na Mesa de } \\
\text { Rendas da Villa da Barra) }\end{array}$ & $\begin{array}{l}\text { Manoel José Gonçalves } \\
\text { e sua mulher } \\
\text { (DEVEDORES) }\end{array}$ & $\begin{array}{l}\text { A Firma Fonseca Rios } \\
\text { \& Cia. } \\
\text { (CREDORES) }\end{array}$ & $13 / 10 / 1878$ & 11 & 33 \\
\hline 36 & $\begin{array}{l}\text { Contrato } \\
\text { social } \\
\text { agrícola } \\
\text { (em que há } \\
\text { referência aos }\end{array}$ & $\begin{array}{lr}\text { VICTORINO, } & \text { PAULO, } \\
\text { FREDERICO, } & \text { REFIRINA, } \\
\text { VICTORINO, } & \text { MARIA, } \\
\text { BENEDITO } & \end{array}$ & $\begin{array}{l}\text { Domingos Rocha da } \\
\text { Silva Rios } \\
\text { (SÓCIO- } \\
\text { PROPRIETÁRIO) }\end{array}$ & $\begin{array}{l}\text { Francisco Coutinho } \\
\text { de Almeida } \\
\text { (ADMINISTRADOR } \\
\text { ) }\end{array}$ & $28 / 12 / 1878$ & 11 & 45 \\
\hline
\end{tabular}




\begin{tabular}{|c|c|c|c|c|c|c|c|}
\hline & $\begin{array}{l}\text { seguintes } \\
\text { escravos...) }\end{array}$ & & & & & & \\
\hline 37 & 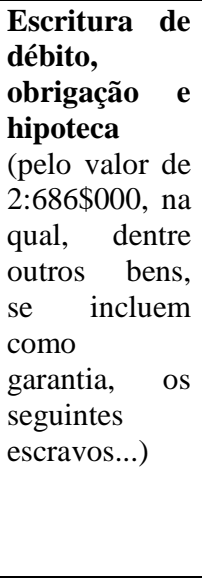 & 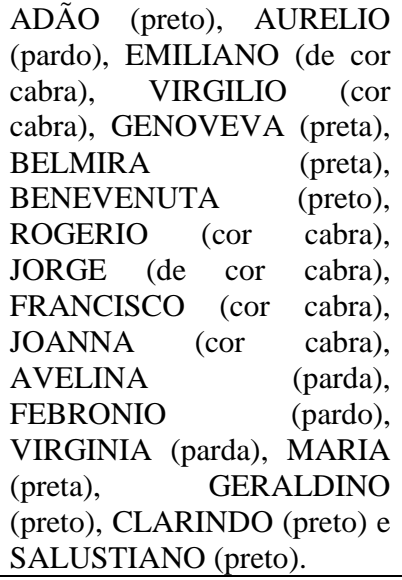 & $\begin{array}{l}\text { D. Ignacia Maria da } \\
\text { Trindade Bastos } \\
\text { (DEVEDORA) }\end{array}$ & $\begin{array}{l}\text { Tenente José dos } \\
\text { Santos Neves } \\
\text { (CREDOR) }\end{array}$ & $15 / 02 / 1879$ & 11 & 52 \\
\hline $\mathbf{N}^{\mathbf{0}}$ & TIPO DOC & ESCRAVO (a) & DONO ESCRAVO & PESSOA REF. & DATA & $\mathbf{L}$ & $\mathbf{F}$ \\
\hline 38 & $\begin{array}{l}\begin{array}{l}\text { Escritura } \\
\text { locação }\end{array} \\
\text { serviços } \\
\text { (pela quantia } \\
\text { de } 1: 000 \$ 000, \\
\text { por três anos e } \\
\text { meio, do } \\
\text { escravo...) }\end{array}$ & JUSTINIANO & $\begin{array}{l}\text { Nos termos da escritura, } \\
\text { em que são partes D. } \\
\text { Maria Gomes da } \\
\text { Conceição e o Major } \\
\text { Antonio Rodrigues da } \\
\text { Cunha. }\end{array}$ & $?$ & $07 / 06 / 1879$ & 11 & 91 \\
\hline 39 & $\begin{array}{l}\text { Escritura de } \\
\text { penhor } \\
\text { (no valor de } \\
800 \$ 000 \text {, cuja } \\
\text { garantia é a } \\
\text { escrava...). }\end{array}$ & $\begin{array}{l}\text { MARIA (parda, solteira, } \\
\text { matriculada em Vitória, nesta } \\
\text { província...). }\end{array}$ & $\begin{array}{l}\text { Abílio Viegas Martins } \\
\text { Guimarães } \\
\text { (DEVEDOR) }\end{array}$ & $\begin{array}{l}\text { Sebastião } \quad \text { José } \\
\text { Barbosa } \\
\text { (CREDOR) }\end{array}$ & $20 / 02 / 1880$ & 11 & 151 \\
\hline 40 & $\begin{array}{l}\text { Confissão de } \\
\text { dívida, com } \\
\text { hipoteca } \\
\text { (dentre as } \\
\text { garantias para } \\
\text { o valor de } \\
7: 527 \$ 570 \text {, } \\
\text { figuram os } \\
\text { escravos...) }\end{array}$ & $\begin{array}{l}\text { CANDIDO, EVENCIO e } \\
\text { JOSÉ. }\end{array}$ & $\begin{array}{l}\text { Reginaldo Gomes dos } \\
\text { Santos (DEVEDOR) }\end{array}$ & $\begin{array}{l}\text { Joaquim Baptista } \\
\text { Pequiá e outros (?) } \\
\text { (CREDORES) }\end{array}$ & $16 / 04 / 1880$ & 11 & $\begin{array}{l}155 \\
\mathrm{v}\end{array}$ \\
\hline 41 & $\begin{array}{l}\text { Confissão de } \\
\text { dívida, com } \\
\text { garantia } \\
\text { hipotecária } \\
\text { (no valor de } \\
\text { 15:000\$000, } \\
\text { constituída de } \\
\text { imóveis e } \\
\text { outros bens, } \\
\text { dentre eles os } \\
\text { escravos...) }\end{array}$ & $\begin{array}{l}\text { JOAQUINA, ANTONIO, } \\
\text { RICARDO, MANOEL e } \\
\text { VICENTE }\end{array}$ & $\begin{array}{l}\text { Francisco Vicente de } \\
\text { Faria e sua mulher } \\
\text { Ernestina Maria de } \\
\text { Oliveira Faria } \\
\text { (DEVEDORES) }\end{array}$ & $?$ & $26 / 04 / 1880$ & 11 & 158 \\
\hline 42 & 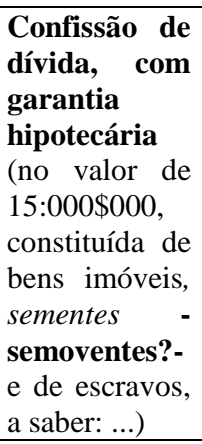 & $\begin{array}{l}\text { PEDRO, ANTONIO, JOÃO, } \\
\text { URSULA, MARIA, } \\
\text { JANUÁRIO e GERTRUDES. }\end{array}$ & $\begin{array}{l}\text { José Cosme da Motta } \\
\text { (DEVEDOR) }\end{array}$ & $\begin{array}{l}\text { José Alves da Fonseca } \\
\text { (CREDOR) }\end{array}$ & $18 / 05 / 1880$ & 11 & $\begin{array}{l}166 \\
\mathrm{v}\end{array}$ \\
\hline
\end{tabular}




\begin{tabular}{|c|c|c|c|c|c|c|c|}
\hline 43 & $\begin{array}{ll}\begin{array}{l}\text { Escritura } \\
\text { permuta }\end{array} & \text { de } \\
\text { escravos } & \\
\text { (valor: } & \\
1: 000 \$ 000 & ?, \\
\text { dos } & \\
\text { escravos...) }\end{array}$ & $\begin{array}{l}\text { RAMIRO (crioulo) } \\
\text { por } \\
\text { DIONILIO }\end{array}$ & $\begin{array}{l}\text { São partes na escritura, } \\
\text { outorgantes } \\
\text { reciprocamente } \\
\text { outorgados (?): José } \\
\text { Vicente de Faria e } \\
\text { Aureliano José de Faria. }\end{array}$ & $\begin{array}{l}\text { (não seriam estes os } \\
\text { "permutantes"?) }\end{array}$ & $24 / 05 / 1880$ & 11 & $\begin{array}{l}167 \\
v\end{array}$ \\
\hline 44 & $\begin{array}{l}\text { Escritura de } \\
\text { transmissão } \\
\text { mutua de } \\
\text { bens imóveis } \\
\text { e semoventes } \\
\text { (nela } \\
\text { figurando os } \\
\text { seguintes } \\
\text { escravos...) }\end{array}$ & $\begin{array}{l}\text { DESIDERIO (preto, no valor } \\
\text { de } 1: 000 \$ 000), \text { LUCINDO } \\
\text { (crioulo, no valor de } \\
1: 500 \$ 000)\end{array}$ & $\begin{array}{l}\text { Figurando como partes } \\
\text { na escritura, os sócios } \\
\text { componentes da extinta } \\
\text { Firma Fonseca Rios \& } \\
\text { Cia. }\end{array}$ & $?$ & 15/07/1880 & 11 & 175 \\
\hline 45 & $\begin{array}{l}\text { Confissão de } \\
\text { dívida, com } \\
\text { hipoteca } \\
\text { (no valor de } \\
\text { 7:000\$000, } \\
\text { cuja garantia } \\
\text { além de } \\
\text { outros bens, é } \\
\text { também } \\
\text { integrada por } \\
\text { escravos, a } \\
\text { saber: ...) }\end{array}$ & $\begin{array}{l}\text { ADÃO (preto), VICENTINO } \\
\text { (pardo), BENEDITA (parda), } \\
\text { ROSA (preta), DOROTHÉA } \\
\text { (preta), ANNA (preta) e } \\
\text { MANOEL (preto) }\end{array}$ & $\begin{array}{l}\text { José Antonio de Faria e } \\
\text { sua mulher D. Anna } \\
\text { Amélia da Conceição } \\
\text { Faria } \\
\text { (DEVEDORES) }\end{array}$ & $\begin{array}{l}\text { Olindo Antonio dos } \\
\text { Santos } \\
\text { (CREDOR) }\end{array}$ & $20 / 05 / 1880$ & 12 & $8 \mathrm{v}$ \\
\hline $\mathbf{N}^{0}$. & TIPO DOC & ESCRAVO (a) & DONO ESCRAVO & PESSOA REF. & DATA & $\mathbf{L}$ & $\mathbf{F}$ \\
\hline 46 & 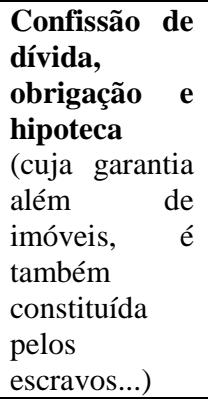 & $\begin{array}{lr}\text { ADÃO, } & \text { VICENTINO, } \\
\text { BENEDITA, } & \text { ROSA, } \\
\text { DOROTHÉA, } & \text { ANNA } \\
\text { MANOEL. } & \end{array}$ & $\begin{array}{l}\text { José Antonio de Faria e } \\
\text { sua mulher D. Anna } \\
\text { Amélia da Conceição } \\
\text { Faria } \\
\text { (DEVEDORES) }\end{array}$ & $\begin{array}{l}\text { Domingos Rocha da } \\
\text { Silva Rios } \\
\text { (CREDOR) }\end{array}$ & $24 / 05 / 1880$ & 12 & 11 \\
\hline 47 & $\begin{array}{l}\begin{array}{l}\text { Confissão de } \\
\text { dívida, com } \\
\text { hipoteca } \\
\text { (no valor de } \\
\text { 15:000\$000, } \\
\text { cuja garantia } \\
\text { além de } \\
\text { imóveis, é } \\
\text { constituída, } \\
\text { também, de } \\
\text { escravos, a } \\
\text { saber:...) }\end{array} \\
\end{array}$ & $\begin{array}{l}\text { MATHEUS } \\
\text { JOAQUIM (preto), } \\
\text { (preta), ROSA } \\
\text { (preto), VICTORIA (preta) e } \\
\text { EDWIRGE (preta) }\end{array}$ & $\begin{array}{l}\text { Gaudino Faria da Motta } \\
\text { e sua mulher D. Rosa } \\
\text { Peniche de Araújo Faria } \\
\text { (DEVEDORES) }\end{array}$ & $\begin{array}{lll}\text { Francisco José } & \text { de } \\
\text { Faria } & & \\
\text { (CREDOR) } & & \end{array}$ & $10 / 07 / 1880$ & 12 & 17 \\
\hline 48 & $\begin{array}{l}\begin{array}{l}\text { Escritura de } \\
\text { dívida, com } \\
\text { hipoteca } \\
\text { (do valor de } \\
\text { 14:000\$000, } \\
\text { cuja garantia } \\
\text { além de } \\
\text { imóveis, } \\
\text { constituem, } \\
\text { também, } \\
\text { objetos da } \\
\text { hipoteca, os } \\
\text { seguintes } \\
\text { escravos...) }\end{array} \\
\end{array}$ & $\begin{array}{lr}\text { MARCOS, } & \text { JO } \tilde{O}, \\
\text { VICENCIA, } & \text { CONSTANÇA, } \\
\text { OLAVIO, } & \text { AVELINA, } \\
\text { ELIRIO, CECILIA E MARIA }\end{array}$ & $\begin{array}{l}\text { Romão Lopes e sua } \\
\text { mulher D. Felisberta } \\
\text { Rosa de Amorim Lopes } \\
\text { (DEVEDORES) }\end{array}$ & $\begin{array}{l}\text { Jeronimo Francisco } \\
\text { Afonso Durães } \\
(\text { CREDOR) }\end{array}$ & $22 / 11 / 1880$ & 12 & $22 \mathrm{v}$ \\
\hline
\end{tabular}




\begin{tabular}{|c|c|c|c|c|c|c|c|}
\hline 49 & 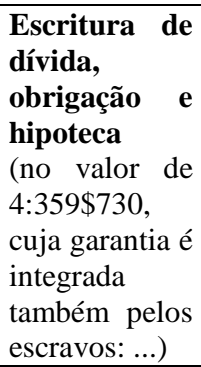 & $\begin{array}{l}\mathrm{ADÃO} \text { (preto) e CIRILLO } \\
\text { (cor cabra) }\end{array}$ & $\begin{array}{l}\text { Reginaldo Gomes dos } \\
\text { Santos } \\
\text { (DEVEDOR) } \\
\text { D. Maria Antonia do } \\
\text { Sacramento } \\
\text { (HIPOTECANTE) }\end{array}$ & $\begin{array}{l}\text { A Firma Simões Faria } \\
\& \text { Cia. } \\
\text { (CREDORES) }\end{array}$ & $07 / 02 / 1881$ & 12 & 30 \\
\hline 50 & $\begin{array}{l}\text { Escritura de } \\
\text { substituição } \\
\text { de doação } \\
\text { (em que há } \\
\text { referencia, } \\
\text { dentre outros } \\
\text { bens, à } \\
\text { substituição } \\
\text { dos escravos: } \\
\text {...) }\end{array}$ & $\begin{array}{l}\text { REGINA, ANGELICA, } \\
\text { EVENCIO e JOSEFINA }\end{array}$ & $\begin{array}{l}\text { D. Rosa Gomes de } \\
\text { Araújo } \\
\text { (DOADORA) }\end{array}$ & $\begin{array}{l}\text { Em favor de seus } \\
\text { filhos e netos } \\
\text { (DONATÁRIOS) }\end{array}$ & $18 / 04 / 1881$ & 12 & 38 \\
\hline 51 & $\begin{array}{lr}\begin{array}{l}\text { Escritura } \\
\text { penhora }\end{array} & \begin{array}{r}\text { de } \\
\text { de }\end{array} \\
\text { escravos } & \\
(\text { de } & \text { seis } \\
\text { escravos, } & \text { a } \\
\text { saber:...) } & \end{array}$ & $\begin{array}{l}\text { PEDRO, ANTONIO, JOÃO, } \\
\text { URSULA, JANUARIO e } \\
\text { GERTRUDES }\end{array}$ & $\begin{array}{l}\text { José Gomes da Mota } \\
\text { (DEVEDOR) }\end{array}$ & $\begin{array}{l}\text { José Alves da Fonseca } \\
\text { (CREDOR) }\end{array}$ & $05 / 07 / 1881$ & 12 & $43 \mathrm{v}$ \\
\hline 52 & 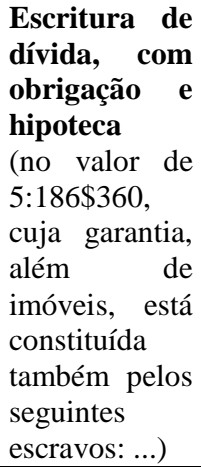 & $\begin{array}{l}\text { ANASTACIO, } \quad \text { FÉ, } \\
\text { FORTUNATO, } \\
\text { SABASTIÃO, DIONISIO, } \\
\text { MONICA e PERCILIANO }\end{array}$ & $\begin{array}{l}\text { D. Adelaide da Silva } \\
\text { Guimarães Leite } \\
\text { (DEVEDORA) }\end{array}$ & $\begin{array}{l}\text { A Firma Leonel } \\
\text { Joaquim de Almeida } \\
\text { Fundão \& Cia. } \\
\text { (CREDORES) }\end{array}$ & $15 / 02 / 1882$ & 12 & $56 \mathrm{v}$ \\
\hline 53 & $\begin{array}{l}\text { Aditamento à } \\
\text { escritura } \\
\text { (de } 1 / 5 / 1882, \\
\text { lavrada às fls. } \\
67 \text { a } 68 \text { do } \\
\text { livro } 12, \text { para } \\
\text { inclusão da } \\
\text { escrava de } \\
\text { nome...) }\end{array}$ & $\begin{array}{l}\text { FELICIANA (filha da escrava } \\
\text { Benvinda, qualificada na } \\
\text { precitada escritura...) }\end{array}$ & $\begin{array}{l}\text { Escritura em que são } \\
\text { partes D. Anna Luisa } \\
\text { Gomes Henrique de } \\
\text { Paiva e Olindo Antonio } \\
\text { dos Santos (?) }\end{array}$ & $?$ & $\ldots / 05 / 1882$ & 12 & 71 \\
\hline 54 & $\begin{array}{l}\text { Confissão de } \\
\text { dívida, com } \\
\text { hipoteca } \\
\text { (no valor de } \\
\text { 2:800\$000, } \\
\text { garantida } \\
\text { com, além de } \\
\text { outros bens, } \\
\text { pelos } \\
\text { seguintes } \\
\text { escravos:...) }\end{array}$ & $\begin{array}{l}\text { VALENTIM e FELIX (de } \\
\text { cor parda) }\end{array}$ & $\begin{array}{l}\text { Virgilio José da Motta e } \\
\text { sua mulher D. Rita } \\
\text { Silvares Motta } \\
\text { (DEVEDORES) }\end{array}$ & $\begin{array}{l}\text { A Firma Fundão } \\
\text { Junior e Cia. } \\
\text { (CREDORES) }\end{array}$ & $30 / 06 / 1882$ & 12 & 75 \\
\hline $\mathbf{N}^{\circ}$. & TIPO DOC & ESCRAVO (a) & DONO ESCRAVO & PESSOA REF. & DATA & $\mathbf{L}$ & $\mathbf{F}$ \\
\hline 55 & $\begin{array}{l}\text { Confissão de } \\
\text { dívida } \\
\text { mediante } \\
\text { hipoteca } \\
\text { (no valor de } \\
17: 412 \$ 000, \\
\end{array}$ & $\begin{array}{l}\text { ANTONIO, ANDRELINO, } \\
\text { PAULO, IVO, DONATO, } \\
\text { FELICÍSSIMO, CAMILLA, } \\
\text { ROZINDA, ANGELICA, } \\
\text { CAROLINA, THEREZA, } \\
\text { JOAQUINA e LUCIANA }\end{array}$ & $\begin{array}{l}\text { D. Angélica Faria Motta } \\
\text { (DEVEDORA) }\end{array}$ & $\begin{array}{l}\text { Major Antonio } \\
\text { Rodrigues da Cunha } \\
\text { (CREDOR) }\end{array}$ & $07 / 10 / 1880$ & 15 & 1 \\
\hline
\end{tabular}




\begin{tabular}{|c|c|c|c|c|c|c|c|}
\hline & $\begin{array}{l}\text { cuja garantia, } \\
\text { além de } \\
\text { outros bens, é } \\
\text { integrada, } \\
\text { também, pelos } \\
\text { escravos: ...) }\end{array}$ & & & & & & \\
\hline 56 & $\begin{array}{l}\text { Permuta de } \\
\text { escravas } \\
\text { (ao preço de } \\
500 \$ 000 \text { cada } \\
\text { uma...) }\end{array}$ & $\begin{array}{l}\text { FLORA } \\
\text { por } \\
\text { MARIA (crioula) }\end{array}$ & $\begin{array}{l}\text { Outorgantes, } \\
\text { reciprocamente } \\
\text { outorgados (?) : Dr. } \\
\text { Raulino Francisco de } \\
\text { Oliveira e João José de } \\
\text { Carvalho e Campos. }\end{array}$ & $?$ & $19 / 01 / 1881$ & 15 & $15 \mathrm{v}$ \\
\hline 57 & $\begin{array}{l}\text { Confissão de } \\
\text { dívida, } \\
\text { mediante } \\
\text { hipoteca } \\
\text { (no valor de } \\
\text { 3:082\$565, } \\
\text { cuja garantia } \\
\text { envolve, além } \\
\text { de outros } \\
\text { bens, os } \\
\text { escravos: ...) }\end{array}$ & 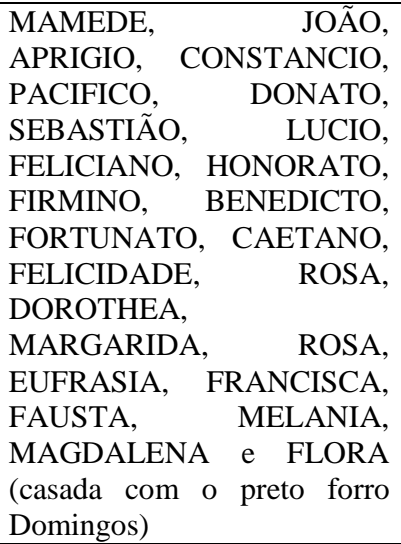 & $\begin{array}{l}\text { João José de Carvalho e } \\
\text { Campos e sua mulher } \\
\text { D. Constantina Maria } \\
\text { de Oliveira } \\
\text { (DEVEDORES) }\end{array}$ & $\begin{array}{lr}\text { Domingos } & \text { Rocha da } \\
\text { Silva } & \text { Rios } \\
\text { (CREDOR) } & \end{array}$ & $19 / 01 / 1881$ & 15 & $16 \mathrm{v}$ \\
\hline 58 & $\begin{array}{l}\text { Confissão de } \\
\text { dívida, com } \\
\text { hipoteca } \\
\text { (no valor de } \\
2: 500 \$ 000, \\
\text { cuja garantia, } \\
\text { além de } \\
\text { outros bens, } \\
\text { envolve os } \\
\text { escravos: ...) }\end{array}$ & $\begin{array}{l}\text { FREDERICO (preto, } \\
\text { matriculado no Município de } \\
\text { Villa da Barra) e JOANNA } \\
\text { (de cor preta, matriculada na } \\
\text { Coletoria Geral de Santa } \\
\text { Cruz), ambas averbadas em } \\
\text { São Mateus. }\end{array}$ & $\begin{array}{l}\text { Rufino Vicente de Faria } \\
\text { e sua mulher D. Rita } \\
\text { Francisca de Souza } \\
\text { Faria } \\
\text { (DEVEDORES) }\end{array}$ & $\begin{array}{l}\text { Major Antonio } \\
\text { Rodrigues da Cunha } \\
\text { (CREDOR) }\end{array}$ & $05 / 02 / 1881$ & 15 & 23 \\
\hline 59 & $\begin{array}{l}\text { Confissão de } \\
\text { dívida } \\
\text { (no valor de } \\
\text { 1:960\$000, } \\
\text { cuja garantia, } \\
\text { além de bens } \\
\text { imóveis, } \\
\text { envolve, } \\
\text { também, os } \\
\text { escravos...) }\end{array}$ & VICENTINO e DOROTHÉA & \begin{tabular}{l}
\multicolumn{3}{l}{ José Antonio de Faria e } \\
sua mulher D. Anna \\
Amélia de \\
(DEVEDORES)
\end{tabular} & $\begin{array}{l}\text { Major Antonio } \\
\text { Rodrigues da Cunha } \\
\text { (CREDOR) }\end{array}$ & $08 / 02 / 1881$ & 15 & 24 \\
\hline 60 & 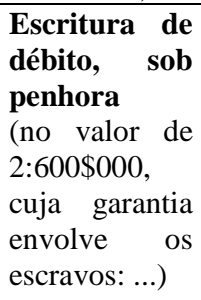 & $\begin{array}{l}\text { MERENCIANA (preta) e } \\
\text { MANOEL (cor cabra) }\end{array}$ & $\begin{array}{l}\text { Domingos } \\
\text { Monjardim } \\
\text { (DEVEDOR) }\end{array}$ & $\begin{array}{lr}\text { Capitão } & \text { Manoel } \\
\text { Lopes de } & \text { Azevedo } \\
\text { (CREDOR) } & \end{array}$ & $21 / 02 / 1881$ & 15 & 27 \\
\hline $\mathbf{N}^{\mathbf{0}}$. & TIPO DOC & ESCRAVO (a) & DONO ESCRAVO & PESSOA REF. & DATA & $\mathbf{L}$ & $\mathbf{F}$ \\
\hline 61 & 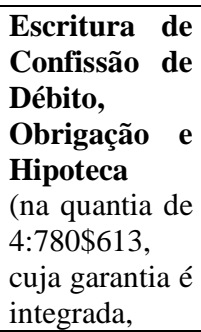 & $\begin{array}{l}\text { JACINTO, } \\
\text { UBALDEDICTO, } \\
\text { GRACILIANO e } \begin{array}{r}\text { JULIANA } \\
\text { (casada com } \\
\text { liberto) }\end{array}\end{array}$ & $\begin{array}{l}\text { Joaquim Francisco da } \\
\text { Silva e sua mulher D. } \\
\text { Leocádia Francisca dos } \\
\text { Santos Sila } \\
\text { (DEVEDORES) }\end{array}$ & $\begin{array}{l}\text { Domingos Rocha da } \\
\text { Silva Rios } \\
\text { (CREDOR) }\end{array}$ & $28 / 03 / 1881$ & 15 & 33 \\
\hline
\end{tabular}




\begin{tabular}{|c|c|c|c|c|c|c|c|}
\hline & $\begin{array}{l}\text { também, pelos } \\
\text { escravos: ...) }\end{array}$ & & & & & & \\
\hline 62 & $\begin{array}{l}\text { Escritura de } \\
\text { Dívida, sob } \\
\text { penhor } \\
\text { (no valor de } \\
920 \$ 720 \text {, cuja } \\
\text { garantia } \\
\text { envolve } \\
\text { escravo...) }\end{array}$ & APRIGIO (crioulo) & $\begin{array}{l}\text { Luiz Pereira } r \\
\text { Vasconcellos e sua } \\
\text { mulher D. Constança } \\
\text { Maria do Rosário } \\
\text { Vasconcellos } \\
\text { (DEVEDORES) }\end{array}$ & $\begin{array}{l}\text { Domingos Rocha da } \\
\text { Silva Rios } \\
\text { (CREDOR) }\end{array}$ & $09 / 05 / 1881$ & 15 & $38 \mathrm{v}$ \\
\hline 63 & $\begin{array}{l}\text { Confissão de } \\
\text { dívida, com } \\
\text { hipoteca } \\
\text { (no valor de } \\
2: 912 \$ 890, \\
\text { cuja garantia } \\
\text { envolve, } \\
\text { também, o } \\
\text { escravo...) }\end{array}$ & $\begin{array}{l}\text { JOSÉ (crioulo, matriculado na } \\
\text { Mesa de Rendas da Villa da } \\
\text { Barra) }\end{array}$ & $\begin{array}{l}\text { Luiz Pereira } r \\
\text { Vasconcellos e sua } \\
\text { mulher D. Constança } \\
\text { Maria do Rosário } \\
\text { Vasconcellos } \\
\text { (DEVEDORES) }\end{array}$ & $\begin{array}{l}\text { Vicente Lopes de } \\
\text { Oliveira } \\
\text { (CREDOR) }\end{array}$ & $09 / 05 / 1881$ & 15 & $40 \mathrm{v}$ \\
\hline 64 & $\begin{array}{l}\text { Confissão de } \\
\text { Dívida, com } \\
\text { Hipoteca } \\
\text { (no valor de } \\
\text { 5:000\$000, } \\
\text { cuja garantia, } \\
\text { envolve, } \\
\text { também, os } \\
\text { seguintes } \\
\text { escravos:...) }\end{array}$ & $\begin{array}{l}\text { FELICIANO, } \\
\text { QUINTINO, } \\
\text { RAMIRO, } \\
\text { PULCHNOEO, } \\
\text { ANSELMO, } \\
\text { JOANINO, CELESTINO, } \\
\text { JOAISISINO, }\end{array}$ & $\begin{array}{l}\text { João de Jesus Silvares e } \\
\text { sua mulher Rufina Pinto } \\
\text { das Virgens } \\
\text { (DEVEDORES) }\end{array}$ & $\begin{array}{lr}\text { Domingos } & \text { Rocha da } \\
\text { Silva } & \text { Rios } \\
\text { (CREDOR) } & \end{array}$ & $06 / 06 / 1881$ & 15 & 50 \\
\hline 65 & $\begin{array}{l}\text { Confissão de } \\
\text { Dívida, com } \\
\text { Hipoteca } \\
\text { (no valor de } \\
\text { 7:000\$000, } \\
\text { cuja garantia, } \\
\text { envolve, } \\
\text { também, os } \\
\text { seguintes } \\
\text { escravos:...) }\end{array}$ & $\begin{array}{l}\text { CLAUDIA, GERALDINO, } \\
\text { FLORENCIA, } \\
\text { MARCOLINO, TIBURCIO, } \\
\text { ATANASIO e ANTONIO }\end{array}$ & \begin{tabular}{lrr} 
Manoel & \multicolumn{2}{c}{ Ribeiro de } \\
Jesus Silvares Sobrinho \\
e sua & mulher & D. \\
Liberata & & Maria \\
Francisca do & Amor \\
Divino & & \\
(DEVEDORES) &
\end{tabular} & $\begin{array}{l}\text { Domingos Rocha da } \\
\text { Silva Rios } \\
\text { (CREDOR) }\end{array}$ & $07 / 06 / 1881$ & 15 & 54 \\
\hline 66 & $\begin{array}{l}\text { Confissão de } \\
\text { Dívida, sob } \\
\text { penhor } \\
\text { (no valor de } \\
1: 175 \$ 000, \\
\text { cuja garantia } \\
\text { envolve o } \\
\text { escravo...) }\end{array}$ & $\begin{array}{l}\text { LIVINIO (cor preta, } \\
\text { matriculado no município de } \\
\text { Arassuahy, da Província de } \\
\text { Minas Geraes, e averbado em } \\
\text { São Mateus) }\end{array}$ & $\begin{array}{l}\text { Manoel Alves de } \\
\text { Magalhães } \\
\text { (DEVEDOR) }\end{array}$ & $\begin{array}{l}\text { Major Antonio } \\
\text { Rodrigues da Cunha } \\
\text { (CREDOR) }\end{array}$ & $07 / 10 / 1881$ & 15 & $71 \mathrm{v}$ \\
\hline 67 & $\begin{array}{l}\text { Confissão de } \\
\text { Dívida, sob } \\
\text { penhor } \\
\text { (no valor de } \\
1: 500 \$ 000, \\
\text { cuja garantia } \\
\text { envolve os } \\
\text { escravos: ...) }\end{array}$ & $\begin{array}{l}\text { MARCELLINO (cor parda) e } \\
\text { MARÇAL (cor parda) }\end{array}$ & $\begin{array}{l}\text { Francisco Coutinho de } \\
\text { Almeida } \\
\text { (DEVEDOR) }\end{array}$ & $\begin{array}{lr}\text { Domingos } & \text { Rocha da } \\
\text { Silva } & \text { Rios } \\
\text { (CREDOR) } & \end{array}$ & $29 / 10 / 1881$ & 15 & 76 \\
\hline 68 & $\begin{array}{l}\text { Confissão de } \\
\text { Dívida, } \\
\text { Obrigação e } \\
\text { Hipoteca } \\
\text { (no valor de } \\
8: 115 \$ 000, \\
\text { cuja garantia, } \\
\text { além de } \\
\text { outros bens, } \\
\text { envolve, } \\
\text { também, os }\end{array}$ & $\begin{array}{l}\text { JOÃO, MARCOLINO E } \\
\text { JACINTHO }\end{array}$ & $\begin{array}{l}\text { José Pinheiro da Silva } \\
\text { (DEVEDOR) }\end{array}$ & $\begin{array}{lr}\text { A Firma } & \text { Leonel } \\
\text { Joaquim de } & \text { Almeida } \\
\text { Fundão } & \& \\
\text { Companhia. } & \\
\text { (CREDORES) } & \end{array}$ & $17 / 01 / 1882$ & 15 & 88 \\
\hline
\end{tabular}




\begin{tabular}{|c|c|c|c|c|c|c|c|}
\hline & escravos: ...) & & & & & & \\
\hline $\mathbf{N}^{0}$. & TIPO DOC & ESCRAVO (a) & DONO ESCRAVO & PESSOA REF. & DATA & $\mathbf{L}$ & $\mathbf{F}$ \\
\hline 69 & 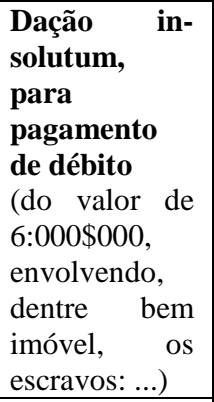 & $\begin{array}{l}\text { DESIDERIO (crioulo), } \\
\text { BELLARMINO (crioulo) e } \\
\text { APPRIGIO (crioulo) }\end{array}$ & $\begin{array}{l}\text { D. Francisca } \\
\text { Leite Sudré } \\
\text { (DEVEDORA) }\end{array}$ & $\begin{array}{lr}\text { Domingos } & \text { Rocha da } \\
\text { Silva } & \text { Rios } \\
\text { (CREDOR) } & \end{array}$ & $22 / 07 / 1882$ & 15 & $\begin{array}{l}119 \\
\mathrm{v}\end{array}$ \\
\hline 70 & $\begin{array}{l}\text { Escritura de } \\
\text { Confissão de } \\
\text { Dívida, com } \\
\text { Hipoteca } \\
\text { (no valor de } \\
7: 360 \$ 320, \\
\text { cuja garantia, } \\
\text { além de } \\
\text { outros bens, } \\
\text { imóveis e } \\
\text { semoventes, é } \\
\text { integrada, } \\
\text { também, pelos } \\
\text { seguintes } \\
\text { escravos: ...) }\end{array}$ & $\begin{array}{l}\text { GRACIANO, } \text { BENEDITO, } \\
\text { AFFONSO, ALEXANDRA, } \\
\text { MARIA, CONSTANÇA, } \\
\text { MANOEL e SEVERIANO }\end{array}$ & $\begin{array}{l}\text { Capitão Adeodato } \\
\text { Antonio dos Santos e } \\
\text { sua mulher D. Joaquina } \\
\text { Carolina dos Santos } \\
\text { (DEVEDORES) }\end{array}$ & $\begin{array}{l}\text { A Firma Leonel } \\
\text { Joaquim de Almeida } \\
\text { Fundão \& Cia. } \\
\text { (CREDORES) }\end{array}$ & $27 / 02 / 1885$ & 18 & 43 \\
\hline 71 & $\begin{array}{l}\text { Confissão de } \\
\text { Dívida, com } \\
\text { Hipoteca } \\
\text { (no valor de } \\
\text { 13:701\$910, } \\
\text { cuja garantia, } \\
\text { além re de } \\
\text { outros bens, } \\
\text { envolve os } \\
\text { seguintes } \\
\text { escravos: ...) } \\
\end{array}$ & $\begin{array}{l}\text { FELISDORO, CATHARINA, } \\
\text { EURICO, MEDORIA, } \\
\text { RUFINA (escrava que tem } 4 \\
\text { ingenuos de nomes Odorio, } \\
\text { Rufina, Carolina e Arabelo), } \\
\text { OFRIDIO, VERÍSSIMA } \\
\text { (escrava que tem um ingênuo } \\
\text { de nome Manoel), MANOEL, } \\
\text { RICARDO e ISIDORO }\end{array}$ & $\begin{array}{l}\text { Olimpio Leite de } \\
\text { Amorim (DEVEDOR) }\end{array}$ & $\begin{array}{l}\text { Tenente José dos } \\
\text { Santos Neves e outros } \\
\text { (CREDORES) }\end{array}$ & $06 / 06 / 1885$ & 18 & 51 \\
\hline 72 & $\begin{array}{ll}\begin{array}{l}\text { Escritura } \\
\text { Dação } \\
\text { solutum } \\
\text { (no valor }\end{array} & \begin{array}{c}\text { de } \\
\text { in- }\end{array} \\
800 \$ 000, & \text { do } \\
\text { escravo...) } & \\
\end{array}$ & DOMINGOS (pardo) & $\begin{array}{l}\text { D. Anna Maria da } \\
\text { Victoria e outros } \\
\text { (DEVEDORES) }\end{array}$ & $\begin{array}{l}\text { Major Antonio } \\
\text { Rodrigues da Cunha } \\
\text { (CREDOR) }\end{array}$ & 03/05/1884 & 19 & 9 \\
\hline 73 & $\begin{array}{l}\text { Escritura de } \\
\text { reconhecime } \\
\text { nto e } \\
\text { confirmação } \\
\text { de dívida e } \\
\text { hipoteca } \\
\text { (no valor de } \\
\text { 1:531\$500, } \\
\text { cuja garantia } \\
\text { envolve, } \\
\text { também, os } \\
\text { escravos: ...) } \\
\end{array}$ & \begin{tabular}{ll} 
JUSTINO & \multicolumn{2}{l}{ (crioulo-preto), } \\
JOAQUINA & (crioula) \\
VICENTINA & (crioula, cor \\
parda) &
\end{tabular} & $\begin{array}{l}\text { D. Anna Francisca da } \\
\text { Victoria } \\
\text { (DEVEDORA) }\end{array}$ & $\begin{array}{ll}\text { Sindulpho } & \text { Maximo } \\
\text { Corsino } & \\
\text { (CREDOR) } & \end{array}$ & $17 / 01 / 1885$ & 19 & 30 \\
\hline 74 & 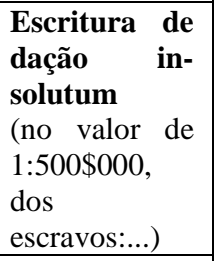 & $\begin{array}{l}\text { LOURENÇO (preto), } \\
\text { BRASILIANO (cor fulla) e } \\
\text { CASSIANO (preto) }\end{array}$ & $\begin{array}{l}\text { Dr. Antonio Gomes } \\
\text { Aguirre } \\
\text { (DOADOR) }\end{array}$ & $\begin{array}{l}\text { Tenente José Antonio } \\
\text { Aguirre } \\
\text { (DONATARIO) }\end{array}$ & 28/08/1886 & 19 & 72 \\
\hline 75 & $\begin{array}{|ll|}\text { Escritura de } \\
\text { Permuta } & \text { de } \\
\end{array}$ & $\begin{array}{l}\text { LUCRECIA (cor cabra) por } \\
\text { VIRGILIA (cor preta, tendo }\end{array}$ & $\begin{array}{l}\text { Outorgantes, } \\
\text { reciprocamente }\end{array}$ & $?$ & $17 / 05 / 1887$ & 19 & $88 \mathrm{v}$ \\
\hline
\end{tabular}




\begin{tabular}{|l|l|l|l|l|l|l|}
\hline & escravas & \multicolumn{2}{l|}{ em sua companhia uma filha } & outorgados: Tenente & & \\
(no valor de & de nome Maria, não & José Antonio Aguirre e & & \\
$750 \$ 000$ para & baptizada, nascida em & José Alexandrino de & & \\
cada uma...) & $31 / 12 / 1886)$. & Almeida. & & \\
\hline
\end{tabular}




\title{
ANEXO 4 \\ TRANSCRIÇÕES DE DOCUMENTOS
}

\author{
Cartas de Alforrias ou Cartas de Liberdade \\ (Transcrições com formato atualizado)
}

$1^{\circ}$ Ofício de São Mateus - Espírito Santo
Livro 11 - Folha 82 (foto P1010057)

Carta de Liberdade de João Cabra. Eu, abaixo assinado, entre os bens que possuo tenho um escravo de nome João, solteiro, cabra, cinqüenta e sete anos, declaramos devidamente matriculado na Coletoria Geral desta cidade e em atenção aos serviços que me é prestado lhe confiro plena liberdade de que agora, desde já. Por ser verdade e por não saber ler e nem escrever pedi ao senhor Lactâncio Custódio Pereira que este o mim fizesse e em rogo assinasse na presença de três testemunhas, os senhores capitão Luiz José dos Santos Guimarães e Joaquim Monteiro de Morais que igualmente assinam. São Matheus, 31 de maio de 1872. Tabelião Sabino José de Oliveira.

\section{$1^{\circ}$ Ofício de São Mateus - Espírito Santo \\ Livro 11 - Folha 109v (foto P1010059)}

Registro de Carta de Liberdade de Dorothéa, conferida por seu senhor o alferes Andrelino Leite de Barcelos na forma abaixo. Carta de Liberdade conferida a favor da escrava Dorothéa. Eu, abaixo assinado, Andrelino Leite de Barcelos, declaro que dentre os bens que possuo, tenho livre de embargos de toda e qualquer ônus a escrava de nome Dorothéa, que pelos bons serviços que me tem prestado e concedo sua liberdade por minha livre e espontânea vontade, ficando como: fica livre de hoje para sempre como se assim nascesse. E para clareza mandei passar a presente Carta a qual assino. São Matheus, onze de agosto de mil oitocentos e setenta e nove. Andrelino Leite de Barcelos. Reconheço ser verdadeira a presente. São Matheus doze de agosto de mil oitocentos e setenta e nove. Sebastião de Oliveira. Tabelião o nome assino em público Sabino José de Oliveira. São Matheus, doze de agosto de mil oitocentos e setenta e nove. Tabelião Sabino José de Oliveira.

\section{$1^{\circ}$ Ofício de São Matheus - Espírito Santo Livro 18 - Folha 31v (foto P1010119)}

Registro de Carta de Liberdade da escrava Laura. Pela presente dou esta carta de liberdade a minha escrava Laura, matriculada neste município, com a matricula 1446 da Matricula Geral da Relação pela quantia de seiscentos mil réis que recebi de seu bemfeitor José Joaquim de Souza Graça a passo desta podemos desde já entrar na posse de sua liberdade como se de ventre livre nascesse para ser titulo passo a presente. São Matheus, sete de setembro de mil oitocentos e oitenta e quatro. Abílio Viegas Martins, depois de ter aqui registrado, entreguei o original ao assistente Antônio Feliz que recebeu a que aqui assino. Eu, Bernardino de Senna, tabelião, que a escrevi e assino. Bernardino de Senna. Antônio Fidelis Cardoso. 
Registro de Carta de Liberdade de Ricardo. Pela presente, na qualidade e procurador bastante do meu cunhado, José Antônio de Oliveira Júnior, conforme a procuração datada de maio nas notas do tabelião Couto Grito, livro 52 folha 196v na Corte passada Rosário número 96, concede plena e inteira liberdade gratuita ao escravo de nome (rasurado), digo de nome Ricardo, crioulo, filho de Lourenço, matriculado na Colhetoria Geral desta cidade com o número 1462 da matricula geral em vinte e seis de agosto de mil oitocentos e setenta e dois e para constar, faço e assino a presente. São Matheus, quatorze de maio de mil oitocentos e oitenta e quatro. Joaquim Monteiro de Morais. Reconheço verdadeira a firma supra. São Matheus, quatorze de maio de mil oitocentos e oitenta e quatro. Eu, Sabino José de Oliveira, tabelião, a escrevi em publico e rogo. Com testemunho e sinal publico. Sabino José de Oliveira. D. Gr. Que nada mais tinha na dita carta que fielmente aqui registrei e a mesma reporto em poder do apresentante. São Matheus, quatorze de maio de mil oitocentos e oitenta e quatro. Tabelião Sabino José de Oliveira.

\section{$1^{\circ}$ Ofício de São Matheus - Espírito Santo Livro 6 - Folha 8 (foto P1010002)}

Carta de liberdade passada à Catherine do espólio do finado Tenente Coronel Caetano Bento de Jesus Silvério. O doutor Leonardo Marcondes de Toledo Lessa juiz municipal e dos órfãos dos termos reunidos nesta cidade e vila da barra de São Matheus por nomeação de sua majestade que Deus guarde. Faço saber que estando-se a proceder o inventário dos bens do finado tenente coronel Caetano Bento de Jesus Silvério foi entre outros escravos descrito e avaliado adi nome Catherine, preta de sessenta anos, solteira, africana, pela quantia de cento e cinqüenta mil réis; cujo escravo, segundo foi declarado pelo inventariante havia entre o inventariado a quantia de cem mil réis e conto de um documento que a mesma escrava apresentou, restando mais neste a quantia de cinqüenta mil réis que foi recebida de acordo com os interesses do acordo por esta forma a mesma escrava liberta. E por salva guarda mandei passar a presente que lhe irá de titulo São Matheus, três de fevereiro de mil oitocentos e setenta e três. Eu, Bernardino de Senna, escrivão que o escrevi = Leonido Marcondes de Toledo e mais nada continha a dita carta que aqui vai escrita e depois do que entreguei a parte que a recebi. Bernardino de Senna.

\section{$1^{\circ}$ Ofício de São Matheus - Espírito Santo Livro 6 - Folha 8 (foto P1010004)}

Lançamento da Carta de Liberdade da escrava Dorothéa. Pela presente carta, concedemos eu e minha mulher a segurado liberdade na metade de nossa escrava Dorothéa a qual desde já fica forra usando do direito que lhe concedemos de forra a metade. São Matheus quatro de julho de mil oitocentos e setenta e três = Antônio Rodrigues da Cunha e Teodósia Vieira da Cunha $=$ e nada mais havia na dita Carta que aqui fica transcrita que dou fé. Eu, Bernardino de Senna, tabelião que o escrevi e assinei. Bernardino de Senna. 
Registro de Carta de Liberdade conferido pelo doutor Graciano dos Santos Neves a sua escrava criola de nome Luzia. A presente é a carta de alforria de minha escrava Luzia e a faço pelo meu próprio punho em virtude de ter recebido da mãe da mesma escrava a quantia de um conto, quatrocentos mil réis, pode pois a mesma, Luzia, gozar sem mais ônus de sua inteira e perfeita liberdade. São Matheus, doze de janeiro de mil oitocentos e setenta e cinco. Doutor Graciano dos Santos Neves. Escrevo que continha na dita carta, que registrei, ele me remeteu a presente e assino a rogo Horácio Henrique da Silva, por ela não saber escrever. São Matheus, seis de fevereiro de mil oitocentos e setenta e cinco. O tabelião Sabino José de Oliveira.

\title{
$1^{\circ}$ Ofício de São Matheus - Espírito Santo \\ Livro 7 - Folha 70 (foto P1010039)
}

Registro de Carta de Liberdade da escrava Genoveva, como abaixo se declara. Declaro que recebi da escrava Genoveva, preta de nação mina, pertencente a muitíssima senhora Dona Ana Luisa Henrique de Paiva, conforme o ordeno que esta na carta de quatorze de abril a quantia de cento e cinquenta mil réis para indenização por sua liberdade atendendo a serviços prestados pela mesma preta Genoveva com condições de continuar o seu serviço fazendo (ilegível) da dita senhora Dona Ana e por ser verdade passo a presente esta vai feita cujo assinamos. E por isso, assinada como administrador geral. Manoel Monteiro Marques ventura, reconheço verdadeiro, afirmo a supra. São Matheus, trinta e um de julho de mil oitocentos e setenta e cinco. Eu, Sabino José de Oliveira, tabelião, escrevi e assino na presente e a rogo. Nada mais tinha na dita carta que fielmente registrei e comigo assinou João Dias Lopes de Vasconcelos. São Matheus, trinta e um de julho de mil oitocentos e setenta e cinco. O tabelião. Sabino José de Oliveira. João Dias Lopes de Vasconcelos.

\author{
$1^{\circ}$ Ofício de São Matheus - Espírito Santo \\ Livro 10 - Folha 53v (foto P1010071)
}

Lançamento de Carta de Liberdade concedia a Luiza. Pela presente, declaro que sendo senhora e possuidora da criola Luzia, avaliada no inventario do finado marido, em um conto e quinhentos e cinquenta mil réis, e visto o acordo que chamou o juiz dos órfãos. Francisco Nascente de Faria, oferecendo a quantia para libertar a referida Luiza, tenho aceitado o referido valor pela que confiro plena liberdade a mesma Luzia a quem esta servirá de título. São Matheus, dezessete de setembro de mil oitocentos e setenta e oito = Maria Benedita Martins $=$ como testemunhas Manoel Ribeiro de Jesus Silvério $=$ Clementino Peres Silvério, estando reconhecidas as firmas por mim encaminhada $=$ Bernardino de Senna.

\section{$\underline{\text { Alforrias por via judicial }}$}

$1^{\circ}$ Ofício de São Matheus - Espírito Santo 
Livro 18 folha 59 V CARTA DE LIBERDADE JUDICIAL ${ }^{251}$

Registro de carta de Liberdade de Fausta. O doutor de órfãos do Termo da Cidade de São Matheus por nomeação de sua Majestade Imperial, a quem Deus guarde, etc. Faço saber a quem o reconhecimento da presente carta de liberdade haja de comprovar, tendo ouvido pelo juiz Municipal e cartório que este subscreve os autos de arbitramento do escravo matriculado neste município em 26 de agosto sob número 1639 de ordem da matrícula geral depois de seus termos regulares foi dita escrava por sentença do Juiz de 18 do mês corrente considerada liberta por ver assim a escrava entrada com seu valor para a partição competente, por pertencer dito valor a Esmeralda, filha do finado Antonio Leite de Barros e para seu título mandei passar a presente que ela entregou. São Matheus, 27 de novembro de 1885. Eu José Vieira de Senna escrivão escrevi este juramentado. Bernardino de Senna subscrevi = Joaquim Vicente Lopes de Oliveira. Depois de ser copiado o presente entreguei o original por ter que recebeu original que assina. Bernardino de Senna.

Reginaldo Gomes dos Santos.

\section{$1^{\circ}$ Ofício de São Matheus - Espírito Santo Livro 10 folha $53 \mathrm{~V}$ CARTA DE LIBERDADE JUDICIAL ${ }^{252}$}

Lançamento de carta de liberdade concedida a Luisa.

Pela presente declaro que sendo senhora e possuidora da crioula Luisa avaliada no inventário do meu finado marido em um conto quinhentos e cinqüenta mil reis e visto o acordo a que chamou-me o Juiz de Órfãos Francisco Vicente de Faria, apresentando-me, apresentou a referida quantia para libertar a referida Luisa, tendo aceitado o referido valor pelo que certifico plena liberdade a mesma Luisa a quem esta servirá de título. São Matheus dezessete de setembro de mil oitocentos setenta e oito = Maria Benedita Martins = como testemunha Manoel Ribeiro de Jesus Silvério = Clementino Pires Silva. Estevão reconhecidas as firmas por mim tabelião $=$

Bernardino de Senna

\section{$1^{\circ}$ Ofício de São Matheus - Espírito Santo Livro 11 folha 35 CARTA DE LIBERDADE JUDICIAL ${ }^{253}$}

Registro de carta de liberdade de Pedro que foi escravo de Eduardo dos Santos Porto

Na qualidade de curador de meu sogro e senhor Eduardo dos Santos Porto e autorização do muitíssimo doutor Juiz municipal dos órfãos e mediante a quantia de um conto e seiscentos mil reis confiro liberdade ao escravo do dito meu sogro por nome Pedro mulato para que hoje em diante entrou na posse da mesma como se de ventre livre nascesse, sendo-me entre qualquer quantia por intermédio do senhor Jacinto José Rodrigues um conto de reis, e por Estevão (liberto) filho do dito Pedro seis centos mil reis, e assim achando-me satisfeito para a presente carta de liberdade que para garantia firmo. São Matheus e fazenda do Jacará oito de setembro de 1878. Severino Pedroso do Amaral Brandão. Reconheço verdadeira a forma supra. São Matheus 19 de outubro de 1878. Eu Sabino José de Oliveira Tabelião

\section{f. $35 \mathrm{~V}$ foto 1010053}

a assino em pública e com testemunho José de Oliveira. E nada mais continha a dita carta que registrei aprovido de Julião dos Santos Porto em poder de quem ela me reporto e assino por João Antonio dos Santos. São Matheus 19 de outubro de 1878. O Tabelião.

Sabino José de Oliveira

João Antonio dos Santos.

${ }^{251}$ ARQUIVO SÃO MATEUS. Livro 18. Folha 59 V. Carta de liberdade via judicial. Foto: 1010125 a 1010126.

${ }^{252}$ ARQUIVO SÃO MATEUS. Livro 10. Folha 53 V. Carta de liberdade via judicial. Foto: 1010071 a 1010072.

${ }^{253}$ ARQUIVO SÃO MATEUS. Livro 11. Folha ?. Carta de liberdade via judicial. Foto: 1010052 a 1010041. 


\section{$1^{\circ}$ Ofício de São Matheus - Espírito Santo Livro 12 folha 5 CARTA DE LIBERDADE JUDICIAL ${ }^{254}$}

\section{f. 05 foto 1010082}

Carta de liberdade judicial conferida a Idalina como se segue.

f. 06 foto 1010083

O Alferes Antonio José Vieira de Faria Juiz Municipal e Órfãos em exercício pleno no termo da lei etc. Atendendo a quanto me foi requerido por Idalina escrava pertencente a Órfã Dona Rita filha do Doutor Graciano dos Santos Neves, e parecer do curador geral dos órfãos neste termo, relativamente a liberdade da mesma escrava, com a indenização de seu valor, resolvi de conformidade com o artigo 48, 56 e 56 (sic) parágrafo $1^{\circ}$ do regulamento a que se refere o decreto número 5135 de 13 de Novembro de 1872 conferir-lhe a presente carta de liberdade que agora de ora em diante como se de ventre livre nascida houvesse. E para seu título mandei passar a presente em que assino. Vila da Barra de São Matheus, cinco de março de 1880. Eu Manoel Lucio Fernandes Rocha escrivão a subscrevi. Antonio José Vieira de Faria. Registrada no livro de notas número onze. Barra seis de março de 1880. O Tabelião Fernandes Rocha. E nada mais se via na dita carta que aqui fica fielmente copia. Depois de que entreguei o original ao representante Vicente Lopes de Oliveira que como recebeu aqui assinou e Eu Bernardino de Senna Tabeliã que o escrevi. São Matheus 8 de março de 1880.

Bernardino de Senna.

\section{$1^{\circ}$ Ofício de São Matheus - Espírito Santo Livro 12 folha 89 V CARTA DE LIBERDADE JUDICIAL ${ }^{255}$}

Registro de carta de liberdade de Guilhermina na forma abaixo.

O doutor Antonio Martins de Miranda

\section{f. 90 foto 1010096}

juiz dos órfãos do Termo da cidade de São Matheus por Sua Majestade O Imperador Que Deus Guarde. Faço saber a todas as autoridades a quem o conhecimento desta pertencer que a escrava crioula de nome Guilhermina, preta, solteira, natural da cidade com profissão da lavoura trinta e dois anos de idade matriculada na coletoria geral desta cidade em 31 de julho de 1872, com os números 327 da matrícula geral 23 da relação tendo exibido no ato de sua avaliação no inventário amigável a que procederão o viúvo de Dona Rita Maria da Conceição Barra a cujo casal pertencia, na importância de setecentos mil reis, por ser este o preço de sua avaliação, lhe concedo plena e irrevogável liberdade que passa a dizer de ora em diante como livre, na vista do que depõem ao artigo 11 da lei de 28 de setembro de 1871. e para constar mandei passar a presente. Cidade de São Matheus, 17 de setembro de 1882. Eu Sabino José de Oliveira escrivão que a escrevi $=\mathrm{O}$ juiz Municipal dos órfãos = Antonio Martins de Miranda. E nada mais se viu na dita carta que depois de aqui registrada entreguei ao apresentante de como recebeu aqui assinou. Eu Bernardo de Senna o escrevi e assinei. São Matheus 18 de outubro de 1882. Bernardino de Senna.

Rufino Jose de Faria.

\section{$1^{\circ}$ Ofício de São Matheus - Espírito Santo Livro 12 folha 90 CARTA DE LIBERDADE JUDICIAL ${ }^{256}$}

Registro de carta de liberdade a Luis.

\footnotetext{
${ }^{254}$ ARQUIVO SÃO MATEUS. Livro 12. Folha 5 V e 6. Carta de liberdade via judicial. Foto: 1010082 a 1010084.

${ }^{255}$ ARQUIVO SÃO MATEUS. Livro 12. Folha 89 V e 90. Carta de liberdade via judicial. Foto: 1010095 a 1010084.

${ }^{256}$ ARQUIVO SÃO MATEUS. Livro 12. Folha 90 e 90 V. Carta de liberdade via judicial. Foto: 1010098 a 1010100.
} 
Carta de liberdade judicial passada a Luis. O doutor Antonio Martins de Miranda Juiz Municipal dos órfãos do termo da Cidade de São Matheus por

por nomeação de Sua Majestade o Imperador, que Deus o guarde. Faço saber a quem apresente carta de conhecimento haja de competir que tendo o Luis de José de Alexandrino de Almeida requerido seu valor para ser seu senhor e dado com o pecúlio que possuía na Tesouraria cujo arbitramento foi referido Jose Alexandrino de Almeida citado não comparecendo no dia, e sendo apresentado neste juízo por Joaquim de Almeida Fundão uma procuração passada pelo mesmo José Alexandrino outorgando poderes para se dado carta de liberdade de seu escravo referido Luis e suspender então escravo Luis Liberto, assim o declarou mandando que se pagasse e entregou para seu título. Dado e passado nesta cidade de São Matheus, em 17 de outubro de 1882. Bernardino de Senna escrivão que a escrevi = assinado = Antonio Martins de Miranda. E nada mais se continha na dita carta que fica fielmente registrada. Depois do que entreguei a parte que de como recebeu aqui assino a rogo. Otavio Henrique Batista.

Bernardino de Senna.

Otavio Henrique Batista.

\section{$1^{\circ}$ Ofício de São Matheus - Espírito Santo Livro 06 folha 08 CARTA DE LIBERDADE JUDICIAL ${ }^{257}$}

Lançamento de uma carta de liberdade e ex-ofício passada a Veridiana.

Carta de liberdade e ex-ofício. O capitão Luis José dos Santos Guimarães, suplente do juiz de órfãos

\section{f. $08 \mathrm{~V}$ foto 1010005}

em exercício pleno da forma da lei. Faço saber que correndo por este Júri o inventário dos bens do finado Manoel Inácio das Chagas, foi pela inventariante dado carregação a escrava de nome Verediana, de cor preta, quarenta e dois anos, africana, que foi matriculada neste Município em cinco de agosto de mil oitocentos setenta e dois sob os números novecentos oitenta e nove da matrícula e dezessete da relação cuja escrava foi avaliada em um conto de reis, e tendo a mesma escrava apresentado em título de seu pecúlio que estava em poder de seu finado senhor e mais a quantia de trezentos mil reis em moeda, e bem assim um documento de libelo de sua senhora do valor de cem mil reis, completando assim a importância de seu valor lhe mandei passar a presente que lhe servirá de carta de liberdade no gozo da qual pode se considerar de hoje em diante. São Matheus, vinte quatro de setembro de mil oitocentos setenta e três. Eu Bernardino de Senna escrivão que o escrevi. Luis José dos Santos Guimarães. E nada mais havia na dita carta que ficou aqui registrada. Bernardino de Senna.

\section{$1^{\circ}$ Ofício de São Matheus - Espírito Santo Livro 06 folha 114 V CARTA DE LIBERDADE JUDICIAL ${ }^{258}$}

Registro de carta de liberdade judicial passada a Eugenio na forma abaixo.

O tenente Sebastião José Barbosa suplente do segundo Juiz municipal deste termo em exercício na forma da lei. A todos os senhores Desembargadores e juizes a em pessoas a quem o conhecimento desta haja de pertencer. Faço lhe saber que tendo falecido neste termo dona Maria da Conceição procedendo seu inventário em seus bens lhe foi escrito e avaliado um escravo de nome Eugenio de cor pardo, solteiro, matriculado na coletoria geral desta cidade em dois de Abril de mil oito centos trinta dois com os

${ }^{257}$ ARQUIVO SÃO MATEUS. Livro 06. Folha 08 e 08 V. Carta de liberdade via judicial. Foto: 1010004 a 1010006.

${ }^{258}$ ARQUIVO SÃO MATEUS. Livro 06. Folha $114 \mathrm{~V}$ e 91. Carta de liberdade via judicial. Foto: 1010039 a 1010041. 
números quarenta e dois da matricula geral dos escravos desta município e cinco da relação numero seis, e como por este escravo foi excluído em juízo e recolhido no deposito por ordem deste juízo a quantia de quatrocentos mil reis por quanto foi avaliado requerendo que em vista do seu pecúlio que se lhe concedesse seu título de liberdade na forma da lei de vinte oito de setembro de 1871 e achando justo o seu alegado, depois de ter recolhido ao depósito público lhe mandei passar a presente para seu título e conservação de seu direito para que como liberto seja tido hoje para sempre por virtude certa. Dado e passado nesta cidade de São Matheus e os dezesseis de dezembro de mil oito centos setenta e seis. Eu Sabino José

\section{f. 115 foto 1010041}

Silveira escrivão que o escrevi = Sebastião José Barbosa. Título do qual confere a Eugenio sua liberdade judicial na forma da lei e despacho de 12 do corrente mês de dezembro de 1876. E nada mais se via em a dita carta de liberdade judicial que fiz aqui registrar e depois do que entreguei a referida carta no próprio requerente como recebeu aqui assino o termo nosso Ricardo José da Cunha. Eu Bernardino de Senna Tabelião que a escrevi e assinei.

Bernardino de Senna

Ricardo José da Cunha

\section{$1^{\circ}$ Ofício de São Matheus - Espírito Santo Livro 06 folha 64 CARTA DE LIBERDADE JUDICIAL ${ }^{259}$}

Registro de uma carta de liberdade judicial da escrava Camila.

O doutor Francisco Rodrigues Sette Filho Juiz Municipal e do termo desta cidade e Vila da Barra por nomeação de Sua Majestade Imperial que Deus Guarde, etc. Faço saber que correndo pelo Juízo de Órfãos e Inventário do finado Francisco José da Silva, foi entre outros bens avaliados uma escrava de nome Camila, parda, de quarenta anos, solteira, natural de São Matheus, matriculada em vinte três de setembro de mil oito centos setenta e dois com os números mil nove centos e treze da matricula vinte da relação pela quantia de seiscentos mil reis; e tendo-me a mesma escrava requerido para depositar o seu valor afim de que se passasse carta de liberdade, o que assim o fiz, em virtude do precitado no parágrafo segundo do artigo noventa da lei regulamentar de treze de novembro de mil oito centos setenta dois, lhe mandei dar a presente carta de liberdade que lhe servirá de titulo. Dado e passado nesta cidade de São Matheus, em dez de março de mil oitocentos setenta e cinco. Eu Bernardino de Senna escrivão que o escrevi. Francisco Rodrigues Sette Filho = São Matheus 21 de setembro de 1875 = Bernardino de Senna.

\section{$1^{\circ}$ Ofício de São Matheus - Espírito Santo Livro 06 folha 90 V CARTA DE LIBERDADE JUDICIAL ${ }^{260}$}

Registro de carta de liberdade judicial passada a favor do escravo Honório.

O doutor Francisco Rodrigues Sette Filho, Juiz Municipal e dos órfãos do termo reunidos desta de São Matheus por nomeação de Sua Majestade Imperial, que Deus Guarde, etc. Faço saber aos que a presente carta de liberdade judicial virem e seu conhecimento competir que tendo corrido pelo Juízo dos órfãos o inventário do finado Implício Afonso de Barcellos, foi entre outros bens dado a carregação um escravo de nome Honório de cor pardo, de cinco anos, mais ou menos, filho de Benedita forra que foi matriculado neste município em 19 de Agosto de 1872 com os números 1154 da matricula e 6 da relação, o

\section{f. 90 foto 1010034}

escravo foi avaliado por cento e cinqüenta mil reis, e tendo a mãe do referido escravo me requerido para entrar uma valer para o depósito afim de obter sua carta de liberdade assim foi definido mandando que fosse se valer entregou depósito público como assim o fez e por isso em virtude disposição do artigo $4^{\circ}$ do livro 112040 de 28 de setembro de 1871 lhe mandei dar a presente que lhe servirá de titulo. São Matheus

${ }^{259}$ ARQUIVO SÃO MATEUS. Livro 06. Folha 64. Carta de liberdade via judicial. Foto: 1010026.

260 ARQUIVO SÃO MATEUS. Livro 06. Folha $90 \mathrm{~V}$ e 91. Carta de liberdade via judicial. Foto: 1010033 a 1010034. 
18 de maio de 1876. Eu Bernardino de Senna escrivão que o escrevi $=$ Francisco Rodrigues Sette Filho $=$ Carta de liberdade judicial que lhe serviu-se mandar a Honório. E nada mais se via em a dita carta que escrevi de ate aqui registrado entreguei apresentante que como recebeu aqui assinou. Em 18 de maio de 1876. Eu Bernardino de Senna Tabelião que o escrevi e assinei.

Bernardino de Senna

Francisco Vicente Ferreira Machado.

\title{
$1^{\circ}$ Ofício de São Matheus - Espírito Santo Livro 06 folha 80 V CARTA DE LIBERDADE POR DESISTÊNCIA ${ }^{261}$
}

\begin{abstract}
Registro de carta de liberdade da menor de nome Maria

Eu abaixo assinada declaro que desisto dos direitos que sobre a Maria, filha de minha escrava Rosalina de idade de trinta e oito anos, matriculada em São Matheus sob os números mil oitocentos e quarenta e nove de cor preta, natural desta cidade na Província do Espírito Santo, solteira. Cria de cor preta de idade ano e meio, natural da mesma cidade e Província e matriculada nesta ali sob o número mil duzentos cinqüenta, tendo por ___ afim de restituir-lhe a sua natural liberdade e por da quantia que representa o seu valor. Para que sirva esta carta de liberdade a referida cria passo o presente documento em que me assino. Rio de Janeiro, seis de janeiro de 1876. Ana Luisa G. M de Paiva. E mais nada se via na dita carta que fica aqui fielmente copiado, depois do que entreguei o original a parte de como recebeu aqui assinada a seu rogo Clementino Peixoto da Silva. Eu Bernardino de Senna Tabelião que escrevi e assinei. Bernardino de Senna.

Clementino Peixoto da Silva.
\end{abstract}

\section{$1^{\circ}$ Ofício de São Matheus - Espírito Santo Livro 01 folha 139 V CARTA DE LIBERDADE JUDICIAL ${ }^{262}$}

Registro de uma carta de liberdade passada a favor da Escrava digo passada a favor da parda Rufina que me foi apresentada pelo capitão José Afonso Martins como abaixo.

O cidadão Antonio Leite de Barcellos, substituto do juízo municipal e o órfãos desta cidade e São Matheus etc. Faço saber aos que apresente carta de liberdade virem, que havendo-me requerido a preta Rufina, escrava do casal Antonio Correa Henrique deposito da quantia de um conto e cem mil reis proveniente de sua avaliação por afim de ser por tal quantia afim de ser por tal quantia para a liberta, mandei ouvir os interessados e como nenhuma objeção fosse da parte deles apresentada mandei depositar a referida quantia e passar a presente carta de liberdade a referida parda Rufina como se de ventre livre nascesse servindo esta de seu título. E para cujo fim interponho minha autoridade. Cidade de São Matheus primeiro de julho de mil oitocentos sessenta e quatro. Eu Henrique e Francisco José da Silva escrivão a escrevi. Antonio Leite de Barcello. Vale selo expansa =

\section{f. 140 foto 1010088}

Antonio Leite de Barcellos (com rubrica). E mais nada se continha a dita carta que aqui fielmente copiei depois de que entreguei ao apresentado. Depois de ter aqui assinado, eu Bernardino de Senna escrivão que a escrevi e assinei em vinte e nove de dezembro de 1866. Bernardino de Senna José Afonso Martins.

\section{$1^{\circ}$ Ofício de São Matheus - Espírito Santo Livro 05 folha 190 CARTA DE LIBERDADE JUDICIAL ${ }^{263}$}

\footnotetext{
261 ARQUIVO SÃO MATEUS. Livro 06. Folha 80 V. Carta de liberdade por "desistência dos direitos". Foto: 1010029 a 1010030.

${ }^{262}$ ARQUIVO SÃO MATEUS. Livro 01. Folha 139 V. Carta de liberdade via judicial. Foto: 1010023 a 1010024.
} 
Registro da carta de liberdade que abaixo se segue da escrava Felisarda dos herdeiros de Eduardo dos Santos Porto

Carta de Liberdade - o cidadão Antonio José Nunes Cardoso, juiz Municipal em exercício deste termo, por nomeação na forma da lei, etc. faz saber que atendendo ao que requereu Felisarda, escrava de Eduardo dos Santos Porto, ao doutor juiz municipal dos termos reunidos, acerca do penho apresentado pela mesma escrava, na importância de trezentos e noventa e cinco reis para o fim de sua liberdade, e assim mais os respectivos interessadas, os quais concordam com a liberdade requerida pela quantia apresida e entregue ao tenente coronel Severino do Amaral Brandão, e tendo mais em vista o despacho do mesmo Doutor Juiz Municipal de vinte e três do corrente exarado na petição da referida Felisarda mandei passar lhe a presente carta de liberdade para que ela jamais, em tempo algum, possa ser chamada ao cativeiro, ficando como de ventre livre tivesse nascido. Pedindo as autoridades de sua Majestade Imperial lhe dêem todo valor indo esta por mim assinada. Vila da Barra do São Matheus, vinte e três de setembro de mil oito centos e setenta e quatro. Eu Manoel Luis Fernandes da Rocha - Antonio José Nunes Cardoso. E nada tinha na dita carta que fielmente a registrei o pedido da libertada, e com original em seu poder vim reposto e de ter recebido comigo assinei a seu rogo.

f. $190 \mathrm{~V}$ foto 1010088

Antonio Joaquim Gomes. São Matheus, 3 de outubro de 1874. O tabelião Sabino José de Oliveira. Antonio Joaquim Gomes

\title{
$1^{\circ}$ Ofício de São Matheus - Espírito Santo* Livro 06 folha 08 CARTA DE LIBERDADE JUDICIAL ${ }^{264}$
}

Carta de liberdade passada a Catherina do espólio do finado Tenente Coronel Caetano Bento de Jesus Silvares. O doutor Leônidas Marcondes de Toledo Lessa Juiz Municipal e de Órfãos dos termos reunidos desta cidade e Vila da Barra de São Matheus por nomeação de Sua Majestade Imperial, que Deus Guarde. Faço saber que estando se a proceder o inventário nos bens do finado do Tenente Coronel Caetano Bento de Jesus Silvares foi entre outros escravos descritos e avaliado a escrava Catherina, preta de sessenta anos, solteira, Africana, pela quantia de cento e cinqüenta mil reis, cujo escrava, segundo foi declarado pelo inventariante, havia entre ao inventariado a quantia de cem mil reis e conta de um documento que a mesma escrava apresentou, restando mais neste ato a quantia de cinqüenta mil reis que foi recebida de acordo com o interessado acordo por esta forma a mesma escrava liberta. E para salva-guarda mandei passar a presente que lhe servirá de título. São Matheus, três de fevereiro de mil oito centos setenta e três. Eu Bernardino de Senna, escrivão que o escrevi = Leonidas Marcondes de Toledo. E mais nada continha a dita carta que aqui vai depois do que entreguei a parte que a recebeu.

Bernardino de Senna.

\section{ESCRITURAS DE COMPRA E VENDA DE ESCRAVOS}

\author{
$1^{\circ}$ Ofício de São Matheus - Espírito Santo \\ Livro 02 folha $150{ }^{265}$
}

Escritura de compra e venda de uma pardinha escrava pela quantia de 500 reis

\footnotetext{
263 ARQUIVO SÃO MATEUS. Livro 05. Folha 190. Carta de liberdade via judicial. Foto: 1010086 a 1010088.

${ }^{264}$ ARQUIVO SÃO MATEUS. Livro 06. Folha 08. Carta de liberdade via judicial. Foto: 1010001 a 1010003.

${ }^{265}$ ARQUIVO SÃO MATEUS. Livro 02. Folha 150V e 151. Foto: 1010322; $1010323 ; 1010324$
} 
Saibam quantos este público instrumento de escritura de compra e venda virem que no ano do nascimento de Nosso Senhor Jesus Cristo de mil oito centos, sessenta, aos vinte sete dias do mês de junho, do dito ano, nesta cidade de São Mateus, e casa de residência do Reverendo José Pereira Duarte Carneiro, onde o tabelião vem aí presente estavam como vendedor o Manoel Duarte Moreira, e como comprador pela menor de nome Felismino o Reverendo José Pereira Duarte Carneiro ambos moradores nesta cidade conhecidos de mim Tabelião e das testemunhas abaixo declaradas e assinadas, em presença das quais me foi dito que era senhor e possuidor de uma escrava parda de nome Rosa de sete anos mais ou menos, cujo escravo por possuir livre de qualquer obrigação ou hipoteca,

\section{f. 151}

vendeu como de fato vendido tem ao comprador José Pereira Duarte Carneiro que a compra para a menor de nome Felismina pela quantia de quinhentos mil reis, esta quantia ele vendedor recebeu do comprador em moeda legal deste Império, e que por isso lhe da plena e geral quitação de pago e satisfeito para mais lhe ser pedida por si nem por seus herdeiros, e que todo o domínio verdadeira e mesma escrava tem, passa-os a pessoa da menor como sua que fica servido por. E logo me foi declarado pelo comprador em nome da mesma Felsimina sua filha natural aceitada apresente escritura de venda da escrava Rosa como nela se acha declarada, e que desde já se dá por empossado da mesma escrava. Em seguida me foi apresentado o talão de pagamento de imposto Provincial, numero trinta e cinco e data de hoje, bem assim a verba de selo na mesma data de hoje. E de como assim tratados ficaram prometerão cumprir me pedirão que lhe lavra a presente escritura em meu livro de notas, e que assim o fiz, depois do que a li em presença das partes e testemunhas que por acharem os contratados como outorgado haviam aceitarão e assinarão e eu a publico e outorguei aceitei e assinei. Testemunhas a tudo presente capitão Jose Afonso Martins e José Antonio, digo, e Antonio Jose d'Oliveira Pinha e eu Bernardino de Sena Tabelião que a escrevi e assino. Declaro que da pagina cinqüenta digo, cento e cinqüenta nesta escritura faltou a declaração de que me foi dito pelo vendedor que era senhor possuidor.

Manoel Duarte Moreira

$\mathrm{P}^{\mathrm{e}}$ Jose Pereira Duarte Carneiro

José Afonso Martins

Antonio José de Oliveira Pereira

Bernardino de Sena

\section{$1^{\circ}$ Ofício de São Matheus - Espírito Santo Livro 04 folha 50 VENDA de ESCRAVO ${ }^{266}$}

Saibam quantos esta virem que no ano do nascimento de Nosso Senhor Jesus Cristo de mil oito centos oitenta e um aos trinta e um dias do mês de janeiro do Ano, nesta cidade de São Matheus, em meu escritório comparecerão presentes partes havidas contratados como vendedor José Maria de Vasconcelos representado pro seu procurador João Antonio dos Santos e com comprador José Rodrigues Esteves de Oliveira moradores o vendedor nesta cidade e o comprador no Termo de Vila da Barra, e pelo mesmo, digo, Barra, reconhecidos de mim Tabelião pelos próprios de quem faço menção e pelo mes

\section{f. $50 \mathrm{~V}$ foto 1010473}

mo vendedor em presença das duas testemunhas no fim assinados, foi dito que ele é senhor e possuidor de um escrava crioula de nome Rosa de vinte para vinte cinco anos de idade, solteira, natural desta cidade de cor preta, porque a por mim livre e desembaraçado de qualquer embargo, hipoteca, com todos os achaques, velhos e novos, lhe vendo, como de fato vendido tem de hoje para sempre, por vendido ao comprador José Rodrigues Esteves de Oliveira por preço e quantia de um conto, quatrocentos e cinqüenta mil reis que entregou pelo comprador em moeda corrente deste Império pelo que lhe dava plena e geral quitação e pago e satisfeito por mais em tempo algum lhe não ver provido por si nem por seus herdeiros e que todos põem, domínio e senhorio, que na dita escrava tem tido, todo deu e transpassa para o comprador que gozará como sua que fica sendo por bem deste e pelo comprador foi dito que aceitava esta escritura de venda que lhe é feita, que desde já se dava por emposse da referida escrava Rosa. Pagou o comprador na agencia de Renda provinciais desta cidade a quantia de quarenta mil reis conforme conhecimento número um desta data, com selo por esta pilha a quantia de dois mil reis como se vê do mesmo conhecimento ainda, assim como mostra o vendedor com a taxa dita

${ }^{266}$ ARQUIVO SÃO MATEUS. Livro 04. Folha 50. VENDA de ESCRAVO. Foto: 1010471 a 1010475. 
Escritura de venda de um escravo de nome Ricardo, que assina como vendedor Luis Monteiro Rangel, pela quantia de $100 \$ 000$.

Saibam quantos este público instrumento de escritura Virem que sendo no ano de Nascimento de Nosso Senhor Jesus Cristo de mil oitocentos sessenta e sete, aos vinte seis idas do mês de Abril do dito ano, nesta cidade de São Matheus, em meu Cartório compareceram partes havidas e contratadas, de uma parte como comprador Ricardo Anterio de Oliveira, e de outra como vendedor Luis Martins Rangel, moradores no Termo desta Cidade, reconhecidos por mim Tabelião e pelas testemunhas abaixo declaradas, e assinadas pelas próprias pessoas de quem faço menção. E pelo vendedor foi dito em presença das testemunhas, que ele é possuidor e Senhor de um escravo de nome Ricardo, com cinco anos de idade, cor preta, natural desta Cidade, e por que a passou livre e desembargada de qualquer penhora ou hipoteca, com todos os seus [ilegível] vende, como de fato vendido tem de hoje para sempre pro meio desta ao comprador Ricardo Antonio de Oliveira por preço e quantia de quinhentos mil reis a que logo foi entregue pelo dito comprador em moeda corrente deste Império pelo que lhe dava plena e geral quitação de pago e satisfeito para, mais em tempo algum lhe der pedido por si nem por seus herdeiros, e que toda a posse, domínio e Senhorio que no dito escravo tinha, todo se de e passada para a pessoa do comprador que o gozará como seu por bem desta. E pela comprador foi dito que aceitava esta escritura de venda a ele feita, e desde já se dava por empossado do referido escravo Ricardo. Pagou o comprador de Selo na Coletoria dos residos geral a quantia de quinhentos reis conforme a verba do selo numero dois com data de hoje. Assim mais pagou a quantia de quarenta mil reis na repartição Provincial conforme o talão numero oito também com data de hoje. E como assim disseram, outorgam e pediram que lhe lavrasse a presente escritura em meu livro de notas o que o fez do que tudo dou fé, e como pessoa pública outorga e assinei, digo, e aceitei em nome das pessoas a quem pertencem para os quais esta li, e por acharem conforme merecido

f. 20 foto 1010034

haviam. Testemunhas a tudo presente Padre José Pereira Duarte Carneiro e Manoel Rangel Jacob e Eu Bernardino de Sena Tabelião que o escrevi e assinei com o comprador e vendedor.

Luis Martins Rangel

Ricardo Antonio de Oliveira

Padre José Pereira Duarte Carneiro

Bernardino de Sena Manoel Jacob

\section{$1^{\circ}$ Ofício de São Matheus - Espírito Santo Livro 02 folha $5^{268}$}

Escritura de compra e venda que passam e assinam como comprador José Pinheiro da Silva e como se seque.

Saibam quantos este público instrumento de escritura de venda verem, que sendo no ano do nascimento de Nosso Senhor Jesus Cristo de mil Oito centos sessenta e sete aos onze dias do mês de fevereiro, nesta cidade de São Matheus, e em meu cartório comparecerão presentes partes havidas e contratadas, como vendedor Manoel Luís de Figueiredo, e como comprador José Pinheiro da Silva, moradores no Termo desta Cidade, reconhecidos pelos próprios de que faço menção, e pelo mesmo vendedor foi dito, em presença de duas testemunhas abaixo nominadas, e asseguradas, que ele é senhor e possuidor de hum escravo de nome Domingos, preto, com trinta anos mais ou menos, natural desta cidade, e uma Escrava de nome Joaquina, crioula com quarenta anos mais ou menos, e porque os possui livres e desembaraçado

267 ARQUIVO SÃO MATEUS. Livro 02. Folha 19 e 20. Foto: 1010030; 1010031; 1010029; 1010030; $1010031 ; 1010032 ; 1010033 ; 1010034$.

${ }^{268}$ ARQUIVO SÃO MATEUS. Livro 02. Folha 5 e. Foto: 101007; 101008; 101009; 1010010; 1010011 
de qualquer penhora ou hipoteca, com todos os seus achaques novos e velhos, vende, como de fato vendido tem de hoje para sempre, por mais desta ao comprador José Pinheiro da Silva pelo preço de quantia de um conto e duzentos, sendo a escrava Joaquina pro quinhentos mil reis, e o escravo Domingos pela quantia de setecentos mil reis, o que logo lhe foi entregue pelo mesmo comprador em moeda corrente deste Império pelo que lhe dá

f. 06 foto 1010010

lhe da plena quitação de pago e satisfeito pra mais em tempo algum lhe não ser pedida por si e nem por seus herdeiros e quitada passo, do mesmo senhorio que nos ditos escravos detido, traspasso para a pessoa do comprador, que fica sendo por bem destar. E pelo comprador foi dito que aceitava esta escritura de venda a ele feita e desde já se dava por empossado dos referidos escravos Domingos e Joaquim. Pagou a compra dos Selo nas Agencia das Rendas Gerais o selo proporcional, como mostrou pelos números com data de hoje. Assim pagou o imposto de oitenta mil reis, como mostrou pelos três e quatro também com data de hoje de como assim o disseram, outorgarão e prometerão cumprir e guardar. Pedirão a mim Tabelião lhes fizesse esta escritura em meu livro de notas, o que fiz, por me __ e de tudo dou fé, e como passo de pública estipulo e aceita li, e por acharem como outorgado haviam assinaram com as testemunhas Josefino Pinto da Conceição Ribeiro e Saturino Joaquim de Oliveira, e eu Bernardino de Sena tabelião que escrevi e assino. Pagarão desta cinco mil reis.

Manoel Luís de Figueiredo Jose Pinheiro da Silva

Josefino Pinto da Conceição Ribeiro Saturino Joaquim de Oliveira

Bernardino de Sena.

\section{$1^{\circ}$ Ofício de São Matheus - Espírito Santo Livro 02 folha $9^{269}$}

Escritura de venda de uma escrava de nome Andresa que a Antonio Ferreira de Sousa Campos Barbosa pela quantia de 600\$000 na forma abaixo.

Saibam quantos este publico instrumento de escritura de venda virem, que sendo no ano do nascimento de nosso Senhor Jesus Cristo de mil oitocentos sessenta e sete aos oito dias do mês de março do dito ano, nesta cidade de São Matheus, em casa de morada do tenente Luis José dos Santos Guimarães a Praça de Comércio, ai presente as partes devidas e contratados, de uma parte como vendedora Deldina Francisca de Souza Campos Barbosa representada por seu procurador bastante o tenente Luis José dos Santos Guimarães, e com comprador Antonio Ferreira de Jesus, moradores no termo desta Cidade, reconhecidas pelos próprios de que faço menção, e pelo mesmo vendedor foi dito por seu procurador, em presença de duas testemunhas abaixo assinados, que ela é senhora possuidora de uma escrava de cor preta, de nome Andresa, de quarenta anos mais ou menos de idade, solteira, crioula, que lhe fora oljudicada no inventario do finado seu marido José Pedro Ran =

\section{f. 10 foto 1010025}

Rangel Barbosa, e por que a passou livre desembaraçada de qualquer embargo, pecúlio, ou hipoteca, com todos os seus achados novos e velhos, vende, como de fato vendido tem por meio desta ao comprador Antonio Ferreira de Jesus pelo preço e quantia de seis centos mil reis, e que logo foi entregue pelo dito comprador em moeda corrente deste império pelo que lhe dava plena geral quitação de pago e satisfeita para mais em tempo algum lhe não ser dada por si, nem por seus herdeiros, e que toda a posse, domínio e senhorio que na dita escrava tem tido todo sede traspassa para a pessoa do comprador, que agora como sua que fica sendo pro bem. E pelo comprador foi dito, que aceitava esta escritura de venda a ele feita, e desde já se dava pro empossado da referida escrava Maria Pagou o comprador e selo na coletoria dos Residos Gerais, a quantia de seiscentos reis, segundo verba do selo numero seis com data de hoje, assim me pagou a quantia de quarenta mil reis do Imposto Provincial na respectiva Agência conforme o talão número oito também com data de hoje. Em seguida da forma apresentado pelo procurador da vendedora os seus poderes na seguinte forma: $\mathrm{N}^{\mathrm{o}}$ cinco = Reis duzentos = pagou duzentos reis. São Matheus 6 de março de 1867 = Império do Brasil = Província do Espírito Santo. Procuração bastante que faz Dona Maria Francisca de Souza Campos Barbosa. Saibam quantos o presente instrumento de procuração

269 ARQUIVO SÃO MATEUS. Livro 02. Folha 9 e 10. Foto: 1010023; 1010024; 1010025; 1010026; $1010027 ; 1010028 ; 1010029$. 
bastante Virem, que sendo no na do nascimento de Nosso Senhor Jesus Cristo de 1867, aos oito dias do mês de março do dito ano nesta Cidade de São Matheus e casa de morada do Tenente Luis José dos Santos Guimarães, ai presente Dona Andina Francisca de Souza Campos Barbosa, reconhecido pelo próprio de mim Tabelião, e das testemunhas abaixo assinadas, em presença das quais por ela outorga me foi dito que pelo presente instrumento na minha pena de direito nomeava e constitui por seu bastante procurador nesta cidade de São Matheus o tenente Luis José dos Santos Guimarães, para por ela, especialmente assinar a escritura de venda de uma escrava de nome Andreza cor fula, crioula com quarenta anos, cuja escrava lhe fora adquirida no inventário do seu findo marido José Pedro

\title{
f. 11 foto 1010025
}

Rangel Barbosa como consta no respectivo inventario para que lhe concede os poderes que se segue, ao qual concede todos os seus poderes com direito permitido. E de como assim o disse, do que dou fé. Faço este instrumento que sendo lido assinado com as testemunhas Luis Lopes de Azevedo e Antonio Francisco Guimarães. Eu Bernardino de Sena Tabelião que escrevi e assino em publico rogo = Bernardino de Sena Aldena Francisca de Souza Campos Barbosa Luís Lopes de Azevedo Antonio Francisco Guimarães. E de como assim disseram a mim Tabelião lhe fosse esta escritura em meu livro de Notas e que a fiz por me cumprir que tudo dou fé com pessoa pública aceito em nome dos outorgados, e se quem mais o devo ser aos quais esta li, e por acharem como outorgados de haver assinaram a rogo do comprador pro não saber escrever assinaram Leonel Joaquim de Almeida Fundão. Testemunhas a tudo presente Sebastião José Barbosa e Luís Lopes de Azevedo. Eu Bernardino se Sena Tabelião que o escrevi. Luis José dos Santos Guimarães Leonel Joaquim de Almeida Fundão

Sebastião José Barbosa Luis Lopes de Azevedo

Bernardino de Sena.

\section{OUTROS DOCUMENTOS REFERENTES A ESCRAVOS}

\section{Permuta de escravo}

\section{$1^{\circ}$ Ofício de São Matheus - Espírito Santo Livro 02 folha 28 PERMUTA ${ }^{270}$}

\author{
Escritura de permuta que passam e assinam João \\ Gonçalves Micha e Manoel Francisco da Mota de \\ um outro escravo como abaixo.
}

Saibam quantos este público instrumento de escritura de permuta virem, que sendo no ano do nascimento de Nosso Senhor Jesus Cristo de mil oitocentos e sessenta e sete, aos vinte e dois dias do mês de junho do dito ano, nesta cidade de São Matheus, em casa de morada de Manoel Francisco da Mota, a praça de São Benedito onde eu Tabelião fui vindo a ser chamado, ai presentes se achava Manoel Francisco da Moto, ambos moradores no termo desta Cidade e Lavados, reconhecidos de mim Tabelião e das duas testemunhas abaixo assinados e assinadas perante as quais me foi dito por Manoel Francisco da Motta que ele é Senhor e possuidor de um escravo de nome Dionísio de trinta e cinco anos, cor preto profissão de roça, e por João Gomes Gonçalves Micha que é senhor de outro escravo de nome Apolinário com trinta anos de idade, natural da Cidade de Vitória, cor preta e profissão Sapateiro, e que por os possuírem livres e desembaraçado de qualquer obrigação contrários de seus achaques novos ou velhos trocam um pelo outro sem restituição de nenhuma das partes; que pela presente escritura passavam todo o domínio, cada um tinham nos referidos escravos, de um para o outro e que desde já se dão por empossados dos mesmos escravos sobe que versa a presente escritura de permuta declarando ambos os contratantes que aceitavam esta

f. 29 foto 1010273

${ }^{270}$ ARQUIVO SÃO MATEUS. Livro 02. Folha 28. Permuta. Foto: 1010267 a 1010273. 
escritura de permuta da forma que nela se acha estipulada. E logo me apresentarão o talão do imposto Provincial sob número e data de 22 vinte e dois de junho de mil oitocentos sessenta e sete, bem a mim de haver pago o selo na coletoria geral como da verba número sete da mesma data acima. E por haverem assim contratados me pedirão que lhe lavrasse a presente escritura em meu livro de notas e que eu o fiz, lavrou as partes que por acharem conforme aceitarão e eu outorguei e acertei em nome dos declarantes. Depois de que assinarão. Declaro que a presente escritura foi me distribuída como se vê da nota da distribuição desta data. Testemunhas a teve presente. Bernardino Alvares de Araújo e José Pereira da Encarnação. Eu Bernardino de Sena Escrivão que o escreveu e assinei. Pagarão desta sete mil reis. João Gomes Gonçalves Michas.

Manoel Francisco da Mota

Bernardino Álvares Pereira de Araujo

Jose Pereira Encarnação

Bernardino de Senna.

\title{
$1^{\circ}$ Ofício de São Matheus - Espírito Santo Livro 02 folha 323 TROCA ${ }^{271}$
}

\author{
Escritura de troca dos escravos Demetrio e \\ Joaquim.
}

Quantos este público instrumento de escritura virem que no ano do nascimento de Nosso Senhor Jesus Cristo de mil oito centos setenta e um, aos oito dias do mês de maio do dito ano nesta cidade de São Matheus, em meu escritório como outorgantes, de uma parte, o procurador do tenente José Antonio Aguiar e do outro João Pereira dos Santos, e de outra a Manoel da Motta, lavrador, moradores nesta cidade e de mim, e das testemunhas abaixo relacionadas, em presença das quais me foi dito por Cosme da Motta, que ele é senhor e possuidor de um escravo de nome Joaquim, que herdou da finada Dona Thereza Maria de Jesus no valor de sete centos mil reis, e que trocava este escravo com o do Tenente José Antonio de nome Demétrio que também herdou de uma finada no valor de um conto e cem reis, havendo de restitui a diferença que há entre valores. E feito procurador do tenente Antonio Aguiar foi declarado que os poderes que tinha de seu constituindo no escravo deste, de nome Demétrio ao declarado, com a diferença nos valores a diferença o mesmo seu constituinte re

\section{f. 324 foto 1010292}

recebeu como se mostra pelo procurações abaixo e portanto reciprocamente transferência um ao outro a forma dos escravos trocados podendo desde já entrarem na pena deles. Em seguida me foi apresentado o talão do Pagamento do Imposto Provincial, sob número onze desta data selado com estampilha correspondente no valor de seis centos mil reis; bem assim e podendo procurador do teor seguinte. Procuração bastante que faz o tenente José Antonio Aguiar. Saibam quantos este publico instrumento de procuração bastante verem que no ano do Nascimento de nosso Senhor Jesus Cristo de mil oitocentos setenta e um, do primeiro dia do mês de maio do dito ano, nesta cidade de São Matheus em meu escritório comparecerão como outorgantes o tenente José Antonio Aguiar, moradores neste termo, Reconhecido pelo próprio de mim Tabelião e das testemunhas a diante nomeadas e assinadas d que dou fé, perante os quais por ele foi dito que por este público instrumento nomeava e constituía seu bastante procurador nesta cidade de São Matheus ao advogado João Pereira dos Santos, oficialmente para poder passar e assinar a escritura de troca do escravo de nome Demétrio, de trinta a quarenta anos que herdou de sua sogra com o escravo Joaquim de quarenta anos mais ou menos de Manoel Carmo da Motta, que este também herdou da sogra do outorgante, sendo o escravo do outorgante herdado no valor de um cento e cem mil reis, e o outro no valor de setecentos mil reis, havendo ele outorgante já recebido a quantia de quatro centos mil reis da diferença entre os valores. E assim me pediu para lhe lavrar este instrumento que lhe li aceitou e assinou e eu Bernardino de Senna Tabelião que escrevi e assinei em público. Bernardino de Senna (estava o sinal público) José Antonio Aguiar. Como testemunha Manoel Lopes de Azevedo. Cosme Francisco de Azevedo. E de como assim tratados ficam remeterão cumprir, pedirão a mim Tabelião que este passasse, a que assim o fiz depois de tido e acharem conforme aceitarão e assinaram, e eu como pessoa pública

${ }^{271}$ ARQUIVO SÃO MATEUS. Livro 02. Folha 323. TROCA. Foto: 1010289 a 1010288. 
outorguei assinei. Testemunhas, para estes Cosme Francisco Lopes e Joaquim José. Eu Bernardino de Senna Tabelião que o escrevi e assino.

João Pereira dos Santos

\section{Hipoteca de escravos.}

\section{$1^{\circ}$ Ofício de São Matheus - Espírito Santo Livro 06 folha 126 HIPOTECA ${ }^{272}$}

Escritura de hipoteca que passa Olívio Bento de Jesus Silvares para por Dona Ana Maria de Oliveira Chagas garantir a legítima dos herdeiros ausentes do finado João José das Chagas.

Saibam quantos este público instrumento de escritura pública virem que sendo no ano do Nascimento de Nosso Senhor Jesus Cristo de mil oitocentos setenta, em sete dias do mês de junho do dito ano, nesta cidade de São Matheus da Província do Espírito Santo, por me distribuída apresente escritura pela nota do desta data que fica arquivada, compareceu como agente hipotecante Olívio Bento de Jesus Silvares nesta cidade, conhecido de mim Tabelião e das testemunhas abaixo nomeadas e assinadas na presença das mesmas testemunhas foi declarado que o mesmo outorgante Olívio Bento de Jesus Silvares lhe oferecia e sujeitava o seu sítio Ribeirão

\section{f. $126 \mathrm{~V}$ foto 1010467}

que se limita pelo lado debaixo em terras a dona Ana Oliveira Chagas pelo e cima com terras do finado José Afonso Martins pela frente com a cancela da ladeira do corgo da bica findo até o Rio Preto; Escravo de nome Isidio preto de 17 anos que foi matriculado em mil oitocentos setenta dois neste município com os números mil cento vinte e quatro de Ordem da matricula e vinte três de Ordem da relações; Isabel preta, solteira de quarenta anos que foi matriculada em mil oito centos setenta neste município com números mil cento e nove de ordem da matricula de Oito de ordem da relação; Ignácio filho de Isabel de oito anos em que foi matriculado em mil oito centos setenta e dois com número mil cento trinta e seis de ordem da matrícula e trinta e cinco da Ordem da Relação e Honorina filha de Isabel de três anos em que foi matriculado em mil oito centos setenta e dois ocupando número mil cento trinta e sete de ordem de matricula trinta e seis de ordem da relação; cujo escravos, ele outorgante, como já disse, oferece desde já por Dona Ana Maria de Oliveira Chagas para garantir aos legítimos herdeiros do finado João José de Chagas que se acha ausente e de quem o mesmo Dona Ana é curadora e depositária. Estando presente a outorgada Dona Ana Maria de Oliveira Chagas por ela foi dito que aceitava a presente escritura para na forma dela dar garantia de sua curadoria dos bens dos ausentes os bens na mesma escritura. Foi apresentado o selo de duzentos reis que o assinei no livro da distribuição e de como assim o devem e declarem e me pedirão que lhe lavrasse a presente escritura e depois de lhe se lida e o acharem conforme aceitaram e assinaram com as testemunhas. Manoel Antonio de Azevedo e Lourenço Bernardo Vieira, assinaram a rogo o Dona Ana, seu filho Leonídio Ignacio de Oliveira Chagas e eu Bernardino de Senna Tabelião que o escrevi e assinei.

Olívio Bento de João Silvares

Leonídio Ignacio de Oliveira Chagas

f. 127 foto 1010470

Manoel Antonio de Aguiar

Lourenço Bernardo Vieira

${ }^{272}$ ARQUIVO SÃO MATEUS. Livro 06. Folha 126. HIPOTECA. Foto: 1010463 a 1010470. 


\section{Penhora de escravos:}

\section{$1^{\circ}$ Ofício de São Matheus - Espírito Santo Livro 06 folha 30 ESCRITURA DE PENHOR ${ }^{273}$}

Escritura de penhor da escrava de nome Severina pela quantia de setecentos mil reis que passa e assina Francisco Coutinho de Essa ao Tenente Sebastião José Barbosa.

Saibam quantos este público instrumento de escritura de penhor virem, que sendo no ano do nascimento de nosso Senhor Jesus Cristo de mil oitocentos setenta e quatro, aos dezessete dias do mês de Setembro de dito ano, nesta cidade de São Matheus, em meu escritório por me ser distribuída a presente escritura, com parecerão como outorgante Francisco Coutinho de Essa lavrador morador no Termo desta Cidade e o Tenente Sebastião Jose Barbosa, negociante, morador nesta mesma cidade, conhecedor de mim, Tabelião e das testemunhas abaixo, em presença que me foi dito pelo primeiro, Francisco Coutinho de Essa que ele tendo recebido nesta data do tenente Sebastião João Barbosa em moeda corrente a quantia de setecentos mil reis se obrigava a pagar-lhe esta quantia nesta data a sete anos e para a garantia desta quantia ele outorgava ao dito Barbosa como penhora a sua escrava de nome Severina, parda, de trinta e cinco anos, solteira natural de São Matheus profissão da Lavoura matriculada neste município em nove de setembro de mil oitocentos setenta dois ocupando os números mil seiscentos oitenta e quatro da matrícula quatro da relação com número cento noventa e dois ficando desde já a escrava entregue ao dito Barbosa para pagamento com seus serviços o premio que podia a referida quantia de sete centos mil reis, em casa, que ele outorgante antes de completar

\section{f. 4 foto 1010407}

seis anos queira sua a penhora obriga pagar-lhe o preço de um e meio por cento ao mês, e se findo os seis anos ele não rever o penhor fica logo a escrava como a ele pertencer e obrigado se a passar-lhe a escritura de venda nesta quantia que recebeu e tem mais direito a haver dele Barbosa remuneração alguma penal que titulo, ficando ele somente abrigado ao Imposto Provincial. Em seguida foi me apresentado pelo dito Barbosa uma escritura de seis, digo, de oitocentos reis do selo proporcional que tem no bilhete d distribuição e me declarou o mesmo que aceitava a presente escritura de penhora e desde já de posse da referida escrava a lhe penhorada. E por assim haverem contratados lavrei a presente escritura que depois de a ler e acharem conforme assinarão com as testemunhas João Jose de Almeida e Antonio José Coelho e eu Bernardino de Senna Magalhães Tabelião que a escrevi e assinei pelo outorgante Barbosa foi dito que a referida escrava falecer fica esta sem efeito algum. Eu Bernardino de Senna Tabelião a escrevi.

Francisco Coutinho de Essa

Sebastião José Barbosa

João José de Almeida

Antonio José Coelho

Bernardino de Senna

\section{$1^{\circ}$ Ofício de São Matheus - Espírito Santo Livro 07 folha 27 EMPRÉSTIMO SOB PENHORA ${ }^{274}$}

Nascimento de nosso Senhor Jesus Cristo de mil oitocentos oitenta e cinco, aos nove dias do mês de Fevereiro nesta cidade de São Matheus em meu cartório compareceram com outorgantes e outorgados como devedor Miguel Custodio Ferreira Barbosa e como credores Fonseca Reis companhias, moradores desta cidade um e outro conhecidos de mim Tabelião pelos próprios do que dou fé, porém ser distribuída esta escritura pela sorte do teor seguinte: D. Oliveira. São Matheus 11 de fevereiro de 1875. A. J. Gomes e por mim devedor em presença das duas testemunhas no fim desta assinadas foi dito que ele outorgante recebeu dos negociantes nesta praça Fonseca Reis Companhia por empréstimo sob penhor, a quantia oito centos mil reis, a juros de um por cento ao mês, até embaraço com o prazo de um ano,

${ }^{273}$ ARQUIVO SÃO MATEUS. Livro 06. Folha 30. Escritura de Penhor. Foto: 1010402 a 1010409.

${ }^{274}$ ARQUIVO SÃO MATEUS. Livro 07. Folha 27. EMPRÉSTIMO SOB PENHORA. Foto: 1010512 a 1010288. 
prometeu que lhe serão pagos mensalmente a contar desta data, dando-lhe em penhor, nas condições abaixo declaradas os escravos

\section{f. 27 foto 1010516}

os escravos seguintes: Joana cabra, de vinte e três anos de idade, solteira, natural desta cidade, jornaleira, matriculada com o número 642 da matrícula geral dos escravos deste município e 2 da relação e Celestina, cabra, filha de Joana sem ofício com quatro anos mais ou menos, matriculada com o número 643 da matricula 3 da mesma apresentada ambas nos aborda um conto e duzentos mil reis, matriculadas em 8 de julho de $1872.1^{\circ}$ que para garantia dos estipulados, ele devedor desde já transmite a forma natural das ditas escravas para os devedores segurando para ele devedor a civil; $2^{\circ}$ que os jornais da escrava Joana, na razão de quinze mil reis mensais serão retidos no devedor em conta dos primeiros que se forem vencendo, e de excederem serão ao mesmo creditado o escravo em conta desta e de outras transações que entre o devedores resolvem realizar $3^{\circ}$ que o alimento, vestuário e tratamento envolutivos referidos escravos será tudo feito pro conta dele devedor; $4^{\circ}$ que as referidas escravas permaneceram apenhadas até ulterior definitivo a junto e valor de contas com os credores do capital, por meios a mais despesas, não só a quantia que recebeu por empréstimo como também até que sejam os credores embolsados diante qualquer quantia que mesmos venha a dever; $5^{\circ}$ que no ato de ajustar o caldo de todas as suas contas com os credores são estes obrigados a lhe restituírem a

\section{f. $27 \mathrm{~V}$ foto 1010519}

a posse dos referidos escravos. $6^{\circ}$ que sendo o prazo de um ano ele devedor não de todo solvido suas obrigações fica os direito salvo de fazerem venda referidos escravos para no pagamento restituindo ao devedor o excedente se levada importância da mesma campo se verificar ser ele devedor para o que lhe conferir os direitos metidos; $7^{\circ}$ que seus escravos em algum deles falecerem, ou qualquer um venham a declinar ou velar, sem ser por culpa ou livre dos credores, será o mesmo devedor obrigado no embolso do que dever embora não esteja findo o prazo do vencimento. Citando presente José Alves da Fonseca representante da firma Fonseca Rios Companhia por ele foi dito que aceita a presente escritura de obrigação contraída com a dita firma em todos as suas condições e possa a mesma firma aceitar obrigações a ela estipulados. Pagou o devedor de selo por estampa devidamente no bilhete redistribuição a quantia de dois mil reis. E detendo mandarão lavrar a presente escritura que depois de lida aceitarão e assinaram e eu como pessoa publica a estipulo e aceito um nome dos outorgantes a de quem mais o devedor. Testemunhas

\section{f. 28 foto 1010523}

testemunhas a tudo presente Ricardo José Letancio Custodio Pereira moradores desta cidade do meu conhecimento que com outorgantes assinarão. Eu Sabino José Oliveira Tabelião a escrevi e assino. O Tabelião.

Sabino José de Oliveira

Miguel Custódio Ferreira Barbosa

Fonseca Rio Companhia

Ricardo José da Cunha

Lutancio Custódio Pereira. 


\section{Aluguel de escravos:}

\section{$1^{\circ}$ Ofício de São Matheus - Espírito Santo Livro 02 folha 365 RECIBO DE ALUGUEL ${ }^{275}$}

Lançamento de um documento apresentado por Joaquim Barbosa de Souza.

Recebi do Senhor Joaquim Barbosa de Souza dez mil reis aluguel de um mês da escrava parda Lucinda que metade forra e que pertence ao espolio do meu falecido Tio João José das Chagas, cujo aluguel é vencido dia vinte um de janeiro a vinte um de fevereiro do presente ano, tendo já outro mês vencido de vinte e um de fevereiro a vinte um de março como São trinta de março de mil oito centos setenta. Manoel Ignácio das Chagas. Recebi mais mil reis de mais três meses de jornal de Luciene por mão do senhor Joaquim Barbosa

\section{f. $366 \mathrm{~V}$ foto 1010300}

cujo três meses vence no dia vinte e um do corrente. São Matheus dezoito de maio de mil oitocentos setenta. Declaro que recebi mais do Senhor Joaquim Barbosa a quantia de duzentos mil reis que deixo em minha mão para que, digo, para quando arranjar o resto, passa carta a dita Lucinda parda que foi do meu tio. O mesmo Chagas reconheceu a assinatura retro pela do próprio Manoel Ignácio das Chagas. Eu Bernardino de Senna Tabelião que o escrevi e assinei em pública. São Matheus dezessete de maio de mil oito centos setenta e dois (estava o sinal público). Bernardino de Senna selado. E nada mais se via no dito documento que aqui transcrevi, depois do que entreguei o original a parte que de como recebeu assinou aqui a seu rogo Lourenço Bernardo Vieira.

O Tabelião Bernardino de Senna

Lourenço Bernardo Vieira.

\section{COARTACÕES/METADE ALFORRIADA}

LIVRO 12 (fl.19)

Registro de carta de liberdade do escravo Sebastião

Pelo presente carta de liberdade que passo de a metade do meu escravo Sebastião de Nação por haver recebido do mesmo a quantia de Oito centos mil reis. Caxueiro vinte seis de junho de 1879. Antonio Rodrigues da Cunha. Registrado a paginas 76 do $5^{\circ}$ Livro de notas. Em 25 de Fevereiro de 1879. B de Senna. Recebi o restante da quantia pela liberdade do escravo acima que gosará desta em diante de completa liberdade Caxueiro 28 de junho de 1880. Antonio Rodrigues da Cunha. E nada mais se via em dita carta aqui fica registrada aqual [entreguei] ao próprio Sebastião e de como recebeo assigno aqui a seu rogo João Martins de Vasconcellos Em 14 de julho de 1880.

Bernard.no de Senna Joao Martins de Vasconcellos

275 ARQUivo SÃo MATEUS. Livro 02. Folha 365. RECIBO DE ALUGUEL. Foto: 1010299 a 1010300. 
LIVRO 12 (f.18)

Registro de Carta de Liberdade do escravo Domingos

Os abaixo assignados, filhos e unicos herdeiros do Snr Domingos José Rodrigues, residentes no Municipio desta Cidade resolvemos conceder liberdade ao escravo de nome Domingos, matriculado na [Collectoria] da mesma Cidade por termos recebido como indennisação a quantia de nove centos e sessenta mil reis e juros vencidos no passado treis annos. Portanto [ilegível] o mesmo Domingos desde apresente data livre e sem condição alguma; e por ser isso de nossa [ilegível] e livre vontade mandar nos passar carta que assignamos. S Matheus vinte treis de Outubro de mil oito centos oitenta e dous Manoel José Rodrigues de Oliveira - Jacintho Jose Rodrigues. E nada mais se via em dita carta que depois de ater aqui registrado, entregui e assignarão assignando por elle não saber escrever Francisco Vieira Lessa. Testemunho presentes José Joaquim de Sousa Graça e José Pedro [ilegível] Sobrinho. Eu Bernardino de Senna. Pagarão 1400

Bernardino de Senna Ricardo José da Cunha Vieira Cecilia Ferreira da Cunha Vieira Francisca Vieira Lessa José Joaq.m de Sz $z^{a}$ Graça

\section{LIVRO 06}

Registro da carta de liberdade da escrava de nome Piedade

Pela presente carta de liberdade em que me assigno[ilegível] mulher renunciamos do direito que temos na escrava (a metade forra) Piedade aqual desta data em diante gosará de sua completa liberdade. S Matheus quinze de outubro de $1876=$ Antonio Rodrigues da Cunha [Theodora] Vieira da Cunha= (estava sellada). Em o que com[ilegível] a carta que me foi apresenta. S Matheus 15 de Novembro de 1876.

Bernard.n de Sena

Registro de carta de liberdade de Dorothéa conferida por seu senhor Alferes Andrelino Leite de Barcellos na forma abaixo

Carta de liberdade conferida a favor da Escrava Dorothéa - Eu abaixo assignado Andrelino Leite de Barcellos declaro que de entre os demais bens que possuo tendo livre e desembargada de tudo e qualquer onus a escrava de nome Dorothéa, que pelos bons serviços [ilegível] parte do lhe concedeo sua liberdade de minha livre e espontanea vontade, ficando, como ficado livre de hoje para sempre, como se assim nascera. E por [clareza] mandou [ilegível] a prezente carta a qual [ilegível] assigno. S Matheus $11 \mathrm{de}$ Agosto de 1879. Andrelino Leite de Barcellos. Reconheco [ilegível] por mim [ilegível]. S.Matheus 12 de Agosto de 1879. Eu Sabino José de Oliveira Tabellião a escrevi e assigno empublico erazo. Em testemunho de verdade estava o signal publico Sabino José de Oliveira. E registrada de [verba] e tambem a pedido da liberta [ilegível] a cujo original em no [ilegível] reposto [ilegível] que assignei [no] rogo por dizer não saber ler nem escrever José Lopes de Oliveira comigo Sabino Jose de Oliveira Tabellião escrevi e assigno S Matheos 12 de Agosto de 1879 O Tabellião Sabino José de Oliveira

Jose Lopes de Oliveira

Lansamento de carta de liberdade da escrava Dorothea

Pela presente carta consedemos eu e minha mulher abaixo assignado liberdade na a metade de nossa escrava Dorothea aqual desde já fica forra gosando do direito que lhe concedemos de forra ametade São Matheus quatro de julho de mil oito centos setenta e tres = Antonio Rodrigues de Cunha $=$ Theodosia Vieira da Cunha $=\mathrm{E}$ nada mais se via a dita carta que aqui fica transcripta de que dou fé Eu Bernardino de Senna Tabellião que o escrevi e assignei

Bernard.no de Senna

Lancamento de uma carta de liberdade de uma criola de nome Durcolina

Disemos nois abaixo assignados, eu José Bento de Jesus Silvares e minha mulher Dona Anna Joaquina do Nascimento que entre os bens que possuimos livres de hypotheca ou outro e qualquer onus, é bem assim uma nossa cria de nome Dorculina filha de nossa escrava Efigenia, cuja cria a forramos de nossa livre vontade e sem constrangimento de pessoa alguma [ilegível] dos nossos parentes herdeiros poderão aceitar 
a esta carta de liberdade como se passada fosse por Tabellião publico; por isso rogamos a Justiça de nossa Magestade o Imperador lhe dé em toda aforça valer e para o seo titulo mandamos passar a presente por José Affonço Martins indo por nos assignado. São Matheos vinte de Desembro de mil oito centos sessenta e Oito $=$ José Bento de Jesus Silvares $=$ Anna Joaquina do Nascimento $=$ Sello $=$ Numero [ilegível] dusentos. São Matheus vinte dois de Desembro de mil oito centos sessenta e Oito. E mais nada continha em a dita carta de liberdade que depois de a ter aqui fielmente[ilegível] [entregui] o original [ao] apresentada abaixo assignado. Eu Bernardino de Senna Tabellião que o escrevi e assigno como apresente

O Tabellião Bernardino de Senna Jose Bento de Jesus Silvares

Carta de liberdade passada a Aldina metade forra do espolio do finado Ten.e Cor.el Caetano Bento de Jesus Silvares

O D.or Leonidas Marcondes de Toledo Lessa Juis Municipal e de Orphãos dos Termos oriundos desta Cidade e do da Villa da Barra de S Matheus por nomiação de S. M. Imperial que Deus G.e [etc] Faço saber que estando se procedendo a inventario nos bens do finado Tenente Cor.el Caetano Bento de Jesus Silvares foi entre outros escravos descripto e avaliado Aldina, parda de vinte annos, casada com Emenegildo liberto em sua ametade em [ilegível], pela quantia de quinhentos mil reis; e sendo pela mesma apresentado em juiso amencionada quantia de quinhentos mil reis que foi recebida pela inventariante em virtude do paragrafo seguinte do art, $4^{\circ}$ do Decreto $n^{\circ}$ [2040] de 28 de setembro de 1870 lhe mandei passar apresente que lhe servirá de titulo: São Matheus quatro de Fevereiro de 1873. Eu Bernardino de Senna escrivão que o escrevi = Leonidas Marcondes de Toledo Lessa

O Tabellião Bernard.no d Senna 


\section{ANEXO 5}

\section{MAPAS DE SÃO MATEUS}

Mapa 1: Mapa do norte do Espírito Santo e da região de São Mateus no século XIX.

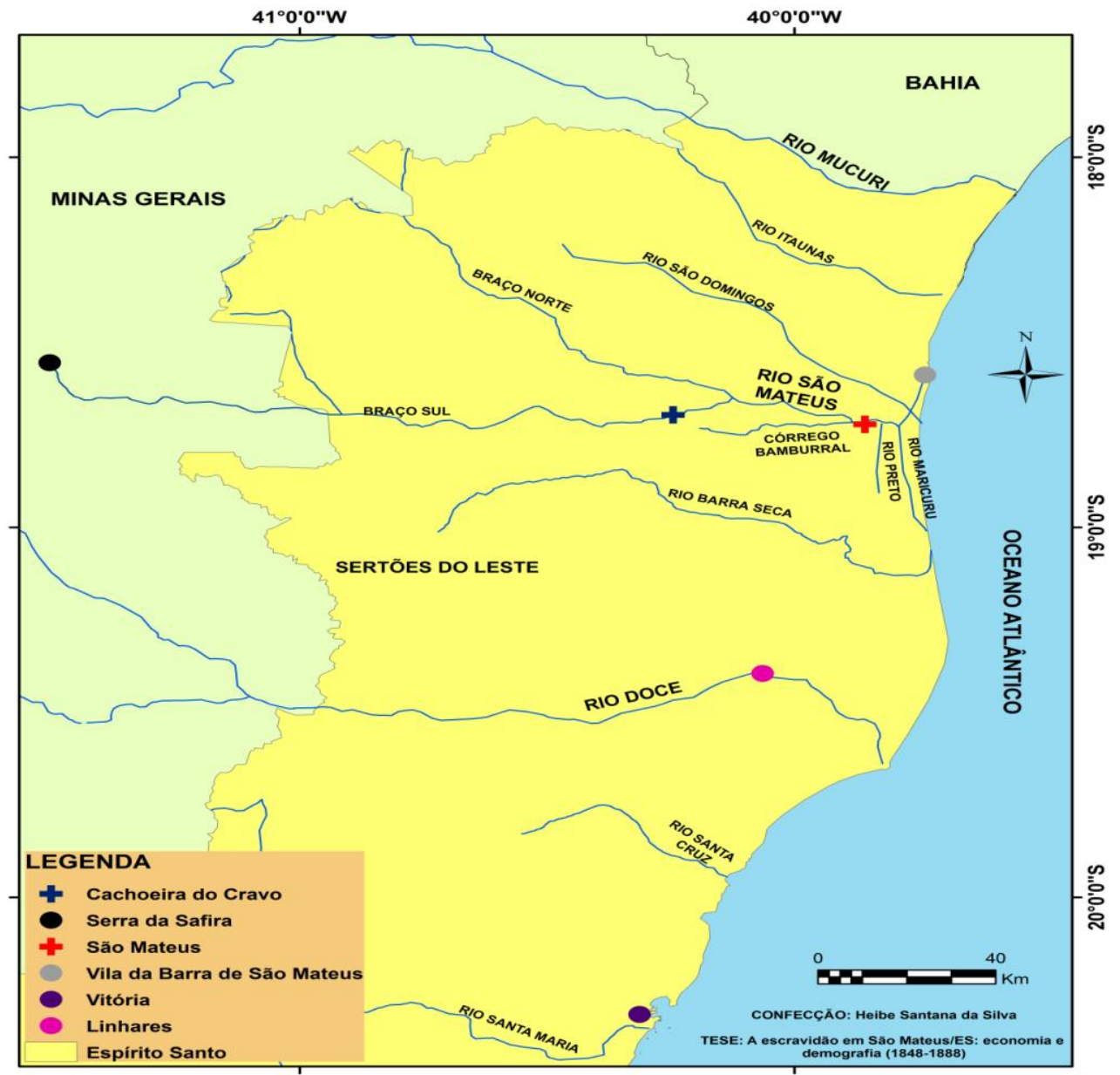


Mapa 2: Mapa do Espírito Santo de 1878, destacando-se o rio São Mateus e o rio São Domingos (deteriorado na área de Vila da Barra e Itaúnas).

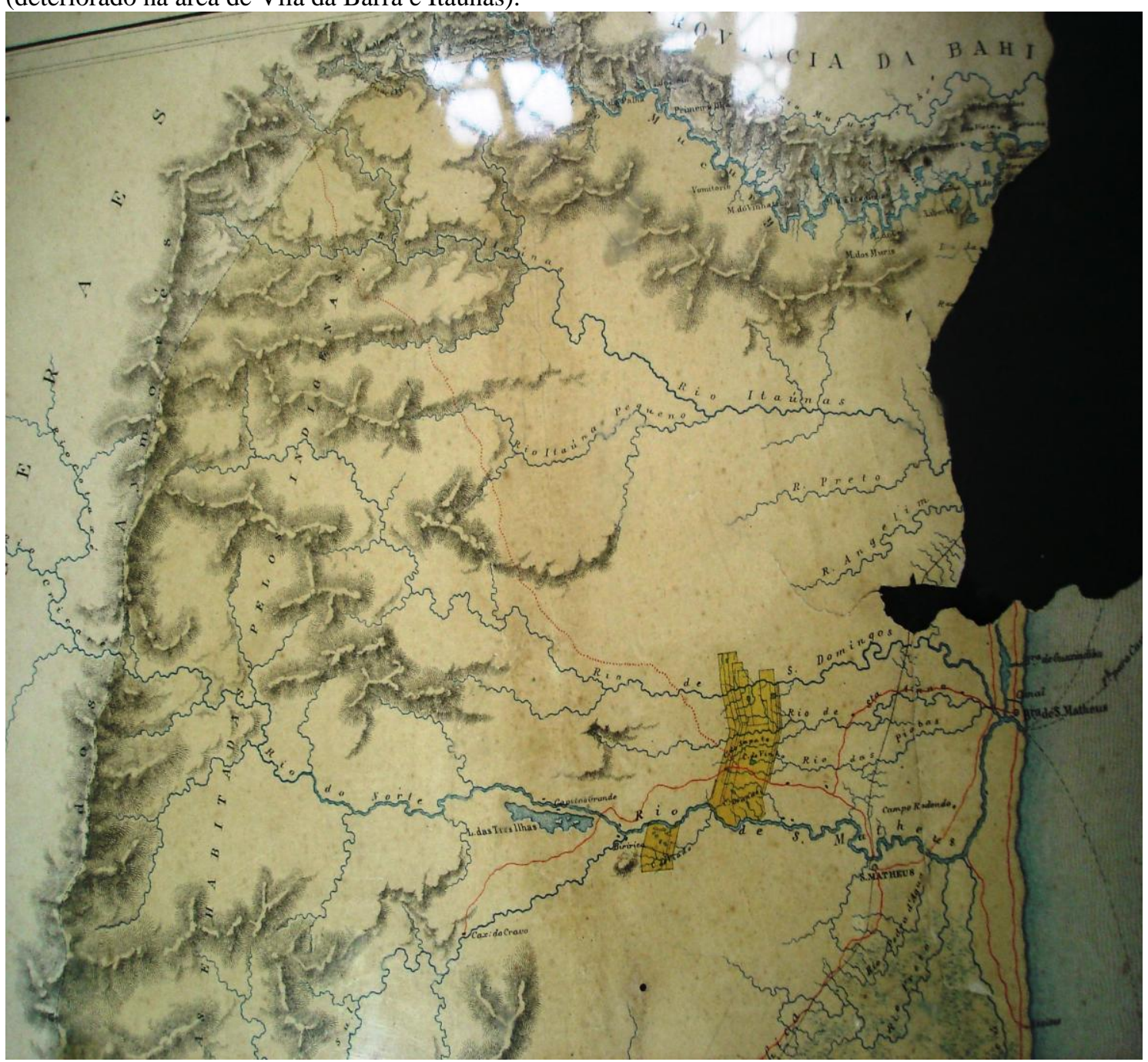

Fonte: Acervo de Eliezer Nardoto. 